UNIVERSIDADE DE SÃO PAULO

FACULDADE DE ECONOMIA, ADMINISTRAÇÃO E CONTABILIDADE DEPARTAMENTO DE ADMINISTRAÇÃO PROGRAMA DE PÓS-GRADUAÇÃO EM ADMINISTRAÇÃO

PERFIS DE CARREIRA DA GERAÇÃO Y

Helena Talita Dante Cordeiro

ORIENTADOR: Prof. Dr. Lindolfo Galvão de Albuquerque

SÃo PAULO 
Prof. Dr. João Grandino Rodas

Reitor da Universidade de São Paulo

Prof. Dr. Reinaldo Guerreiro

Diretor da Faculdade de Economia, Administração e Contabilidade

Prof. Dr. Adalberto Américo Fischmann

Chefe do Departamento de Administração

Prof. Dr. Lindolfo Galvão de Albuquerque

Coordenador do Programa de Pós-Graduação em Administração 
HELENA TALITA DANTE CORDEIRO

\section{PERFIS DE CARREIRA DA GERAÇÃO Y}

Dissertação apresentada ao Programa de PósGraduação em Administração da Faculdade de Economia, Administração e Contabilidade da Universidade de São Paulo, para obtenção do título de Mestre em Ciências.

ORIENTADOR: Prof. Dr. Lindolfo Galvão de Albuquerque

Versão original

\section{SÃO PAULO}

2012 
FICHA CATALOGRÁFICA

Elaborada pela Seção de Processamento Técnico do SBD/FEA/USP

Cordeiro, Helena Talita Dante

Perfis de carreira da geração Y / Helena Talita Dante Cordeiro.

-- São Paulo, 2012.

$184 \mathrm{p}$.

Dissertação (Mestrado) - Universidade de São Paulo, 2012.

Orientador: Lindolfo Galvão de Albuquerque.

1. Administração de carreiras 2. Gerações 3. Jovens I. Universidade de São Paulo. Faculdade de Economia, Administração e Contabilidade. II. Título.

CDD -658.409 
Para o Heitor, minha mãe, Maria Helena e minha irmã, Érica, que me apoiam em cada etapa da minha vida. 


\section{AGRADECIMENTOS}

Produzir uma dissertação é um trabalho muito especial que nos traz reflexões sobre diversos aspectos de si mesmo, pois é praticamente se colocar de forma explícita e formal, redigir seus pensamentos e descobertas ao mesmo tempo em que se inicia um processo de desenvolver e colocar para fora um estilo, uma forma muito única e que nunca havia sido explorada anteriormente. Por isso, as pessoas que contribuíram direta ou indiretamente são fundamentais e muito marcantes na construção da obra e do autor. Agradeço inicialmente ao meu orientador, Prof. Lindolfo, que sempre com um sorriso no rosto me conduziu com muita gentileza me alertando sobre possíveis dificuldades e me dando toda a liberdade e segurança para eu trilhar meu caminho e fazer minhas escolhas.

Agradeço também aos professores Tania Casado e Joel Dutra que me mostraram o conhecimento sobre Carreiras, campo em que se sustenta esse trabalho, e sempre estiveram disponíveis e estimulando minha produção.

Agradeço ao Prof. André Fischer que me mostrou a profundidade e a precisão do nosso campo de estudos de Gestão de Pessoas, sendo um exemplo de dedicação e seriedade.

Agradeço ao Prof. Roberto Sbragia que proporcionou uma experiência fundamental nesse processo: a disciplina de Seminários, que me esclareceu muitas dúvidas, me ofereceu muitos feedbacks e foi fundamental para que diversas decisões fossem tomadas, sendo possível chegar a esse resultado.

Foram fundamentais para a realização deste estudo Sofia Esteves e Danilca Galdini que possibilitaram a aplicação da pesquisa. Agradeço pelo tempo, dedicação e principalmente a grande generosidade de ter aberto suas portas e viabilizado meu trabalho. À Danilca, registro aqui minha admiração pelo amor à pesquisa e pelo carinho, acolhimento e suporte que ela demonstra em cada conversa e cada e-mail trocado.

Agradeço também Davide Aprile, Carolina Minucci e Daniela Giubertoni que com seu apoio e generosidade tornaram possível minha dedicação a estudo.

Gostaria também de agradecer as pessoas que me ampararam de duas formas nesse trabalho, de forma técnica que dando dicas e orientações e também de forma emocional, estando presente com um sorriso tranquilo e inspirador nos momentos de dúvida: Carol 
Shinoda, Fabíola Sarubbi e Carol Dias, amigas muito especiais que foram mais um presente dessa fase da minha vida.

Agradeço imensamente a Kim Samejima que fez com que os números fizessem sentido e trabalhou arduamente comigo nessa dissertação, sendo um exemplo de dedicação, carinho e enorme generosidade. $O$ cuidado e amor de Kim a seu campo de estudo, a Estatística, é inspirador para qualquer pesquisador. Não posso deixar também de manifestar minha gratidão a Mel que com seu sorriso no rosto e gentileza de sempre me recebeu em sua casa, me ofereceu seus finais de semana e me deu muita força para a realização desta pesquisa.

O apoio dos grupos de estudos de "Gestão Estratégica de Pessoas" de "Inovação em Gestão de Pessoas" também foi fundamental, oferecendo sugestões, feedbacks e força para continuar o trabalho de pesquisa e ser uma pesquisadora melhor a cada dia.

Agradeço finalmente aqueles que me apoiaram e que me deram toda a força para eu realizar esse projeto, ao meu marido, Heitor, minha mãe, Maria Helena, minha irmã, Érica e meu sogro, Eduardo. Sem essa base, seria impossível ter chegado até aqui e com essa base, tenho confiança de seguir adiante. 
“(...) we must decide who and what manner of men we wish to be and what calling in life we would follow; and this is the most difficult problem in the world" Marcus Tullius Cicero (escrito no século I a.C., como uma carta para seu filho Marcus, em “On Duties”) 


\section{RESUMO}

A questão geracional se apresenta como tema emergente em gestão de pessoas no Brasil e no exterior. Mudanças demográficas relacionadas ao envelhecimento da população e redução da taxa de natalidade sustentam o interesse pelo assunto. A nova geração, ou Geração Y, que ingressa no mercado de trabalho atualmente, observa uma realidade diferente das gerações anteriores. Com o advento da globalização, das novas tecnologias e do aumento da competitividade, o contrato psicológico de trabalho migrou de um modelo de emprego vitalício para um modelo de independência e autonomia, onde o ator de carreira é responsável pela gestão de sua carreira e pelo seu desenvolvimento. Essas mudanças trouxeram a necessidade do reposicionamento do conceito de carreira e do desenvolvimento de teorias que considerassem aspectos relacionados à mobilidade, busca de um sentido para o trabalho e do sucesso psicológico, tais como, a carreira sem fronteiras e a carreira proteana. Considerando a premência e a necessidade de estudos nacionais empíricos, tanto sobre carreiras, quanto sobre gerações, a presente dissertação teve como objetivo a identificação do perfil de carreira dos indivíduos da geração Y. O perfil de carreira agrupa os indivíduos de acordo com a presença de atitudes de carreira proteana, representada pelas dimensões: autodirecionamento e orientação pelos valores; e de atitudes de carreira sem fronteiras, representada pelas dimensões: mobilidade psicológica e mobilidade física. O estudo é descritivo, quantitativo e a coleta de dados foi realizada através de uma survey eletrônica que teve como base escalas validadas nos Estados Unidos e no Brasil. A amostra é não probabilística e intencional e foi formada por 2.376 jovens. Foram utilizadas a análise fatorial exploratória e a análise fatorial confirmatória, para validação das escalas de atitudes de carreira; a análise de agrupamentos, para a identificação dos perfis de carreira da amostra; e o qui-quadrado, para a análise da relação entre as atitudes de carreira e variáveis demográficas e da relação entre os perfis e as variáveis demográficas. Os resultados das análises fatoriais e do alfa de Cronbach afirmam a validade e a confiabilidade do instrumento utilizado. Foram identificados oito perfis de carreira sendo que cinco deles já haviam sido descritos teoricamente. Os três novos perfis foram descritos e nomeados. O perfil predominante na amostra foi o "Arquiteto da Carreira Proteana" que possui alta presença das atitudes de carreira investigadas. O grupo com menor representação foi o "Perdido" que possui baixa presença das atitudes de carreira. Esses resultados confirmam as teorias de geração e de carreira que descrevem que o fato dos indivíduos mais jovens se socializarem no ambiente de trabalho moderno os leva a adequar seu perfil de carreira a essa realidade. Conclui-se que as novas carreiras são uma realidade para os jovens brasileiros. No entanto, existe uma menor proporção de pessoas com baixas atitudes de carreira em diversas dimensões, indicando que esse é um movimento e ainda não pode ser considerado como fato para todos os indivíduos pesquisados. Identificando-se a necessidade de aprofundamento e o vasto espaço de pesquisa aqui demonstrado, espera-se que esse estudo sirva como convite aos pesquisadores para desenvolverem novos estudos empíricos sobre gerações e carreiras e seus impactos sobre a gestão de pessoas nas organizações brasileiras. 


\begin{abstract}
Generation is presented as an emergent theme in people management in Brazil and other countries. Demographic changes related to the aging population and to the reduction of the birth rate sustain the interest by the subject. The new generation, or Generation $Y$, that is now getting into the workplace notes a different reality compared to the past generations. Globalization, new technologies and the competitiveness increase caused changes in the psychological work contract, which left a model of life time job, for a model of independence and autonomy, where the career actor is responsible for one's career management and for one's development. These changes brought up the need of a review of career concept and the developing theories that considered aspects related to mobility, the search for the meaning of work and the search for psychological success, such as, the boundaryless career and the protean career. Considering the novelty of both themes and the need for empirical national studies, this dissertation had the objective of identifying the career profile of Generation $Y$ members. The career profile groups the subjects according to the presence of protean career attitudes, represented by two dimensions: self-directed career management and valuesdriven; and the presence of boundaryless career attitudes, represented also by two dimensions: psychological mobility and physical mobility. The research is descriptive, quantitative and the data collection was made through an electronic survey that was based on scales validated in the U.S.A. and Brazil. The sample is non-probabilistic and intentional and was composed by 2.376 young respondents. Exploratory factor analysis and confirmatory factor analysis techniques were used to validate the career attitudes scale, cluster analysis was processed to identify the career profiles and the chi-square was used to analyze the relation between career attitudes and demographic variables and career profile and demographic variables. The results of the factor analysis and the Cronbach's alpha affirm the validity and reliability of the instrument. Eight career profiles were identified and five of them were described in a previous theoretical study. The three new profiles were described and named. The predominant profile in the sample was the "Protean Career Architect" that has high presence of the career attitudes investigated. The profile with smaller representation in the sample was the "Lost" that has low presence of the modern career attitudes. These results confirm the generation and career theories that describe that the young people socializing in the modern work environment adapt their career profile to this reality. The conclusion was that the new careers are a reality for the young Brazilians. Nevertheless, there is a small portion of people with low career attitudes in several dimensions, indicating that it is a movement and cannot be considered as a fact for all the people that participated in the study. This dissertation is an invitation for researchers to develop new empirical studies about generations and careers and its impact on people management in Brazilian organizations. The space and need of new researches is clearly present.
\end{abstract}




\section{SUMÁRIO}

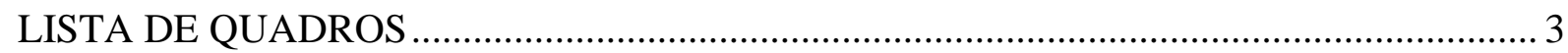

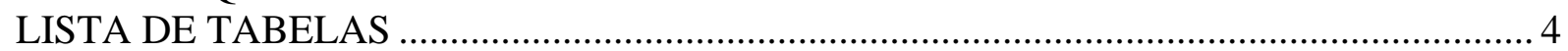

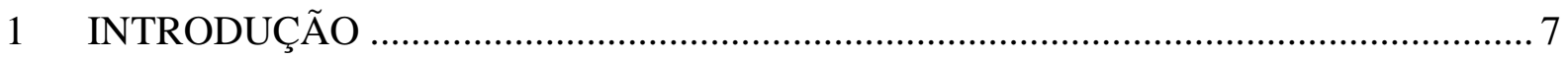

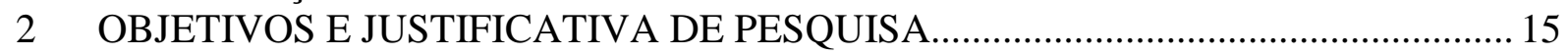

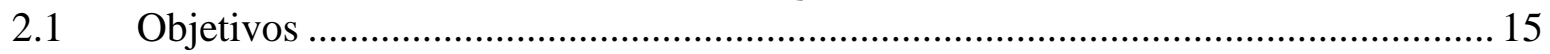

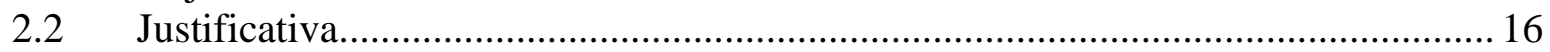

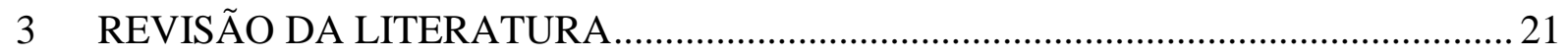

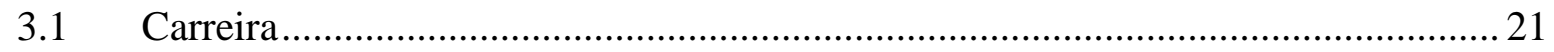

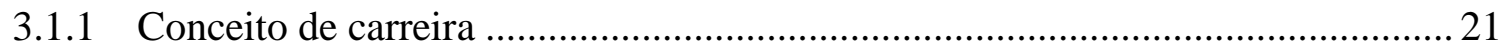

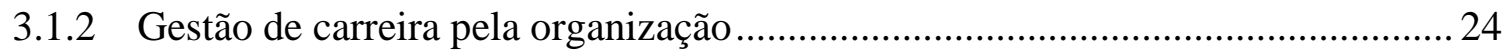

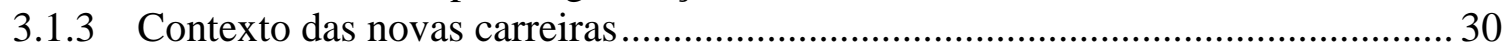

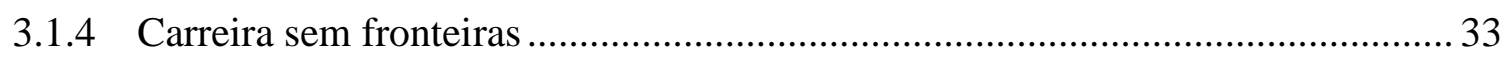

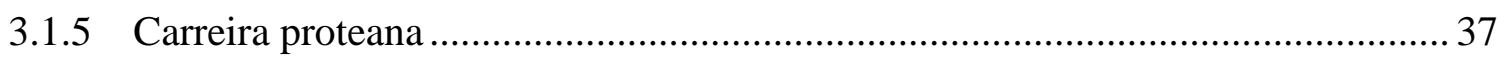

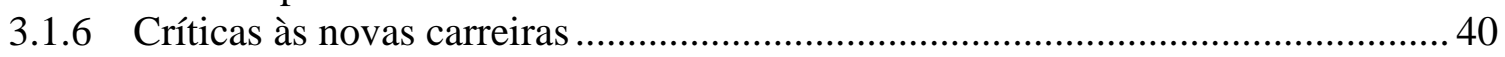

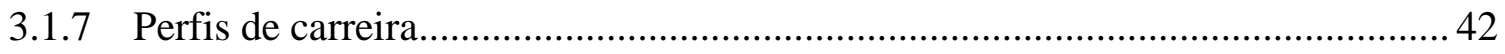

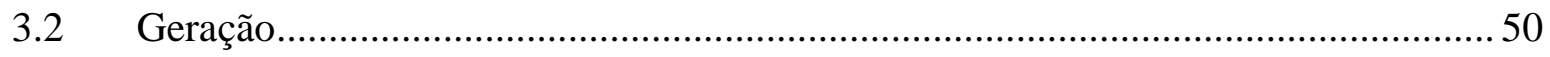

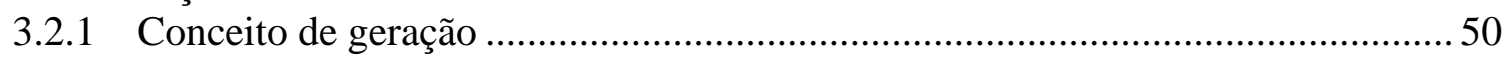

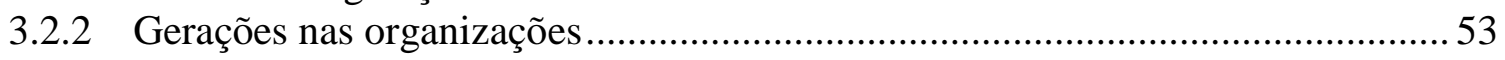

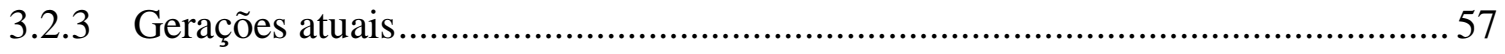

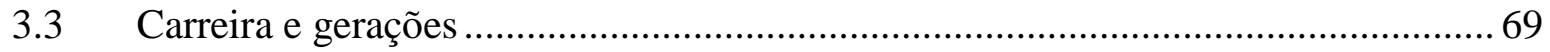

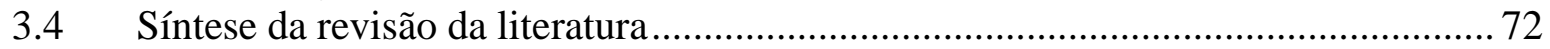

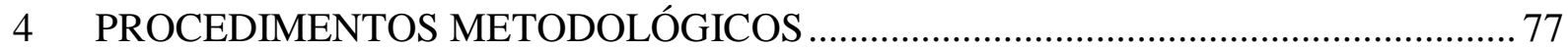

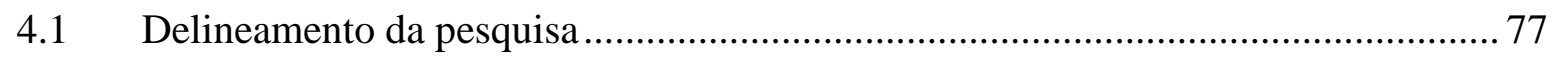

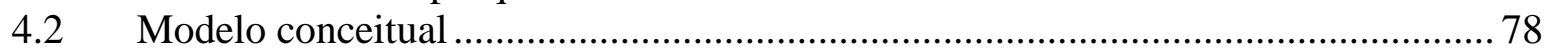

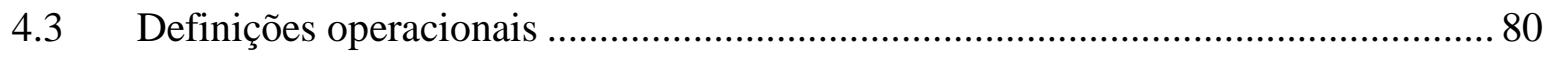

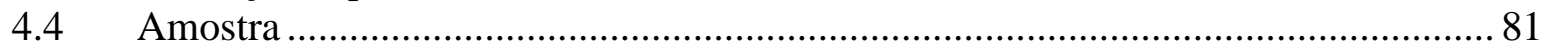

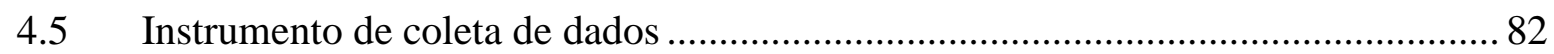

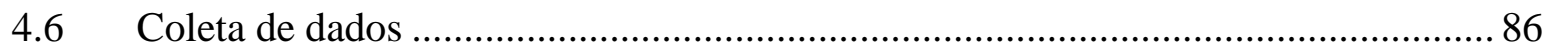

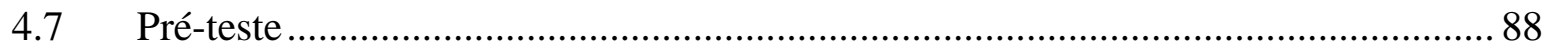

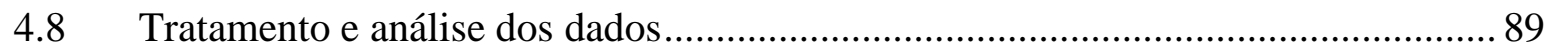

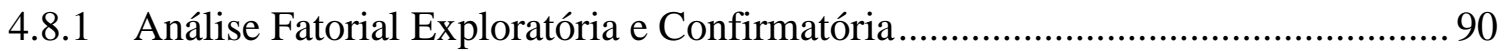

4.8.2 Classificação de acordo com as atitudes de carreira .......................................... 94

4.8.3 Influência das características demográficas e profissionais dos indivíduos em suas

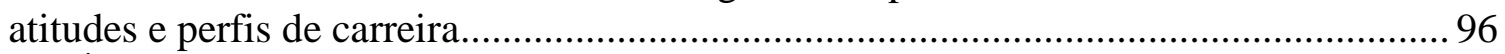

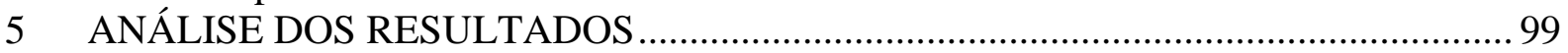

5.1 Perfil demográfico e profissional dos respondentes............................................ 99

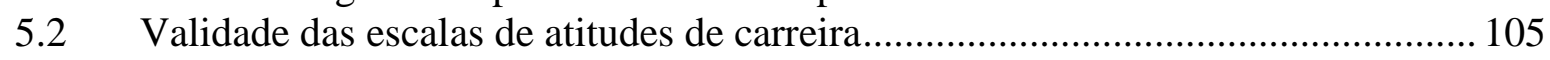

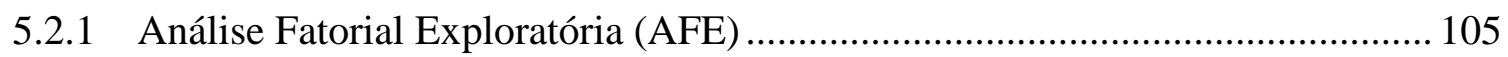

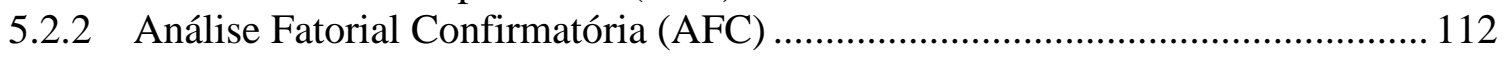

5.3 Classificação dos respondentes conforme suas atitudes de carreira ........................ 115

5.3.1 Análise dos resultados da solução de 8 grupos ................................................ 118

5.3.2 Análise dos perfis encontrados não descritos na teoria.................................... 120

5.4 Análise da influência das características demográficas e profissionais nas atitudes e

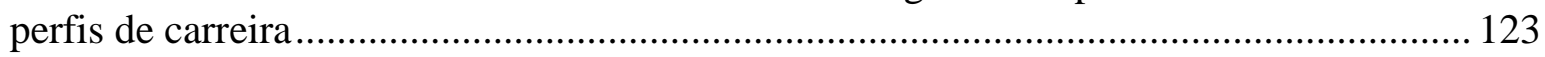

5.4.1 Análise da influência das características demográficas e profissionais nas atitudes de carreira 
5.4.2 Análise da influência das características demográficas e profissionais nos perfis

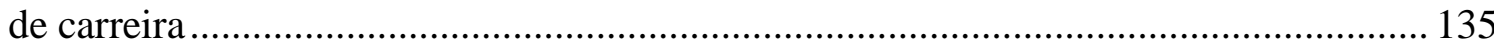

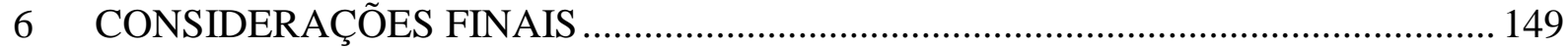

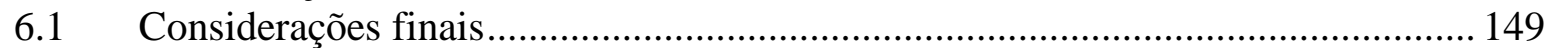

6.2 Limitações da pesquisa e sugestões para estudos futuros ...................................... 157

6.3 Recomendações para as organizações, gestores e atores de carreira ...................... 159

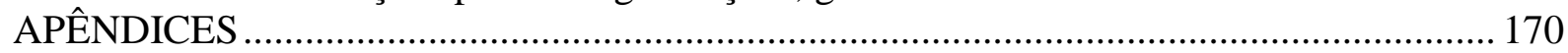

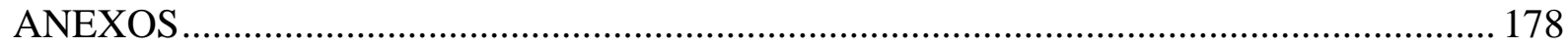




\section{LISTA DE QUADROS}

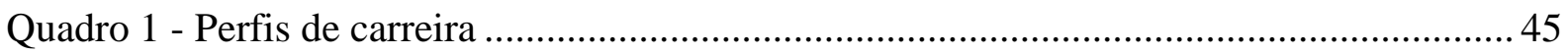

Quadro 2 - Relação entre características demográficas e perfis de carreira.............................. 49

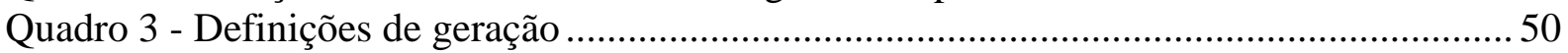

Quadro 4 - Faces dos estudos sobre gerações nas organizações ........................................... 54

Quadro 5 - Descrições das gerações contemporâneas nos Estados Unidos ............................ 57

Quadro 6 - Principais aspectos históricos, econômicos, tecnológicos, políticos e culturais formadores das gerações no Brasil .................................................................5

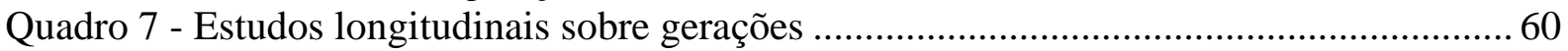

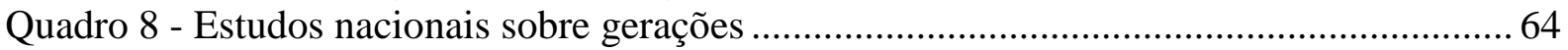

Quadro 9 - Motivos das escolhas das Empresas dos Sonhos dos Jovens nos últimos 6 anos.. 66

Quadro 10 - Características das gerações no Brasil ................................................................ 66

Quadro 11 - Diferenças entre antigas e novas gerações em relação à carreira em diferentes

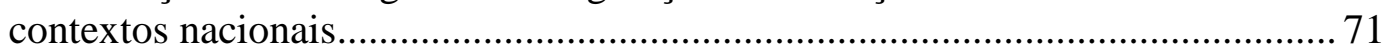

Quadro 12 - Síntese dos conceitos de carreira sem fronteiras e de carreira proteana .............. 72

Quadro 13 - Síntese das dimensões da carreira sem fronteiras e da carreira proteana............. 73

Quadro 14 - Síntese dos principais achados de estudos nacionais e internacionais sobre a Geração Y e gestão de pessoas ........................................................................... 75

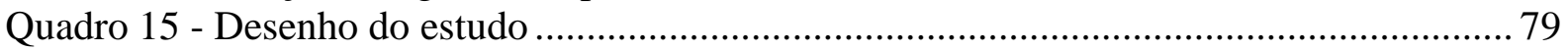

Quadro 16 - Questões da escala de atitude da carreira proteana ......................................... 83

Quadro 17 - Questões da escala de atitude da carreira sem fronteiras .................................... 84

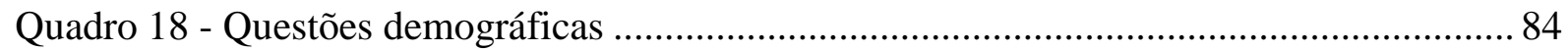

Quadro 19 - Vantagens e desvantagens do questionário eletrônico ......................................... 87

Quadro 20 - Técnicas estatísticas utilizadas neste estudo ..................................................... 90

Quadro 21 - Vantagens e desvantagens dos métodos de agrupamento hierárquico e não

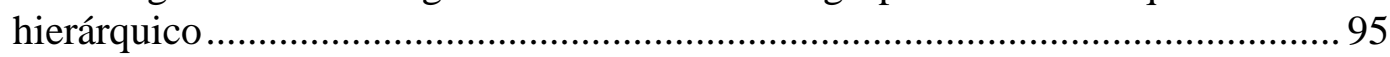

Quadro 22 - Síntese das vinculações significativas entre atitudes de carreira e características demográficas.......................................................................... 154

Quadro 23 - Síntese das vinculações significativas entre perfis de carreira e características

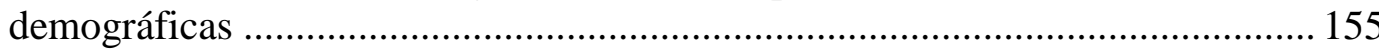




\section{LISTA DE TABELAS}

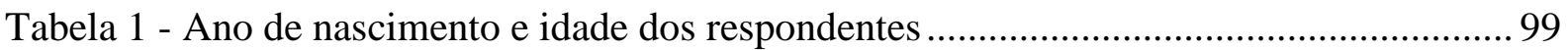

Tabela 2 - Faixa de renda individual média mensal dos respondentes .................................. 100

Tabela 3 - Faixa de renda familiar média mensal dos respondentes ..................................... 100

Tabela 4 - Anos de experiência profissional dos respondentes............................................ 102

Tabela 5 - Número de empresas para as quais os respondentes trabalharam nos últimos 5

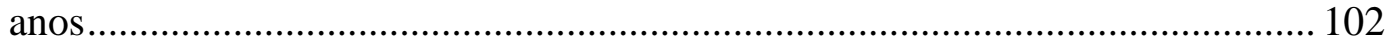

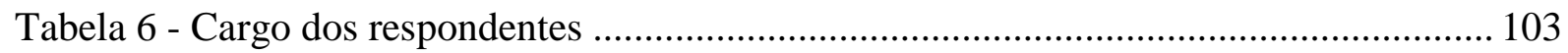

Tabela 7 - Estatística descritiva das questões das escalas de atitudes de carreira proteana e sem fronteiras ................................................................................................. 104

Tabela 8 - Variância total explicada pela AFE - Análise de Componentes Principais

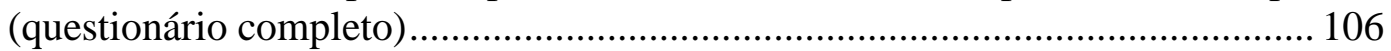

Tabela 9 - Matriz de cargas fatoriais da AFE (questionário completo) ................................ 107

Tabela 10 - Alfa de Cronbach das dimensões e constructos de carreira proteana e sem fronteiras (questionário completo) …………................................................. 108

Tabela 11 - Comparação dos resultados do Alfa de Cronbach do questionário completo e do questionário sem as questões 1,8 e 15 ......................................................... 109

Tabela 12 - Variância total explicada pela AFE - Análise de Componentes Principais (sem as perguntas 1,8 e 15$)$

Tabela 13 - Autovalores empíricos e autovalores randômicos gerados pelo Monte Carlo PCA for Parallel Analysis ............................................................................... 111

Tabela 14 - Matriz de cargas fatoriais da AFE (sem questões 1, 8 e 15) ............................... 111

Tabela 15 - Resultados dos critérios de confiabilidade da AFC por fator e constructo .......... 113

Tabela 16 - Matriz de correlação entre os fatores e constructos ............................................ 113

Tabela 17 - Coeficientes padronizados e valores $t$ de Student dos fatores de acordo com a

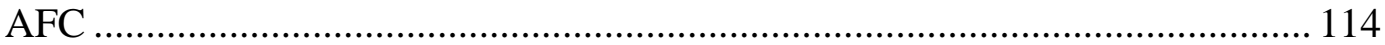

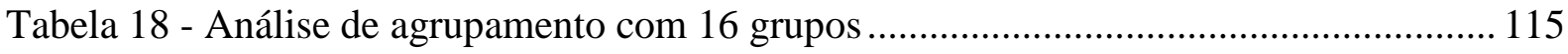

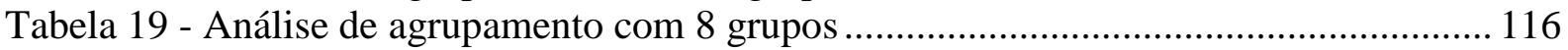

Tabela 20 - Análise de agrupamento com 5 grupos ........................................................... 117

Tabela 21 - Resultados dos valores-p gerados pelo teste Qui-Quadrado analisando a associação entre as atitudes de carreira e variáveis demográficas ...................... 124

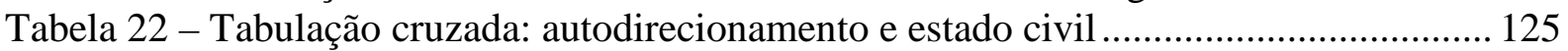

Tabela 23 - Tabulação cruzada: autodirecionamento e renda individual ............................... 125

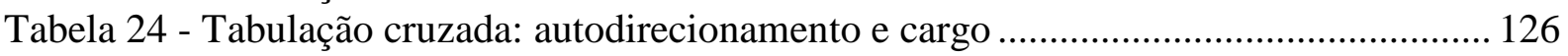

Tabela 25 - Tabulação cruzada: orientação pelos valores e estado/cidade de residência ....... 127

Tabela 26 - Tabulação cruzada: orientação pelos valores e anos de experiência profissional127

Tabela 27 - Tabulação cruzada: mobilidade psicológica e escolaridade ............................. 129

Tabela 28 - Tabulação cruzada: mobilidade psicológica e renda individual .......................... 129

Tabela 29 - Tabulação cruzada: mobilidade psicológica e renda familiar ............................ 130

Tabela 30 - Tabulação cruzada: mobilidade psicológica e anos de experiência profissional 130

Tabela 31 - Tabulação cruzada: mobilidade psicológica e cargo.......................................... 131

Tabela 32 - Tabulação cruzada: mobilidade física e ano de nascimento ............................... 132

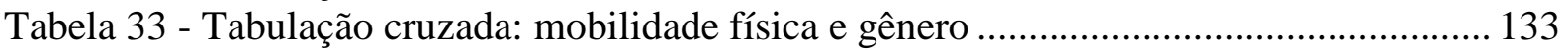

Tabela 34 - Tabulação cruzada: mobilidade física e escolaridade ...................................... 133

Tabela 35 - Tabulação cruzada: mobilidade física e renda individual .................................. 134

Tabela 36 - Tabulação cruzada: mobilidade física e renda familiar....................................... 134

Tabela 37 - Tabulação cruzada: mobilidade física e número de empregadores...................... 135 
Tabela 38 - Resultados dos valores-p gerados pelo teste Qui-Quadrado analisando a associação entre os 8 perfis de carreira encontrados e variáveis demográficas .. 136

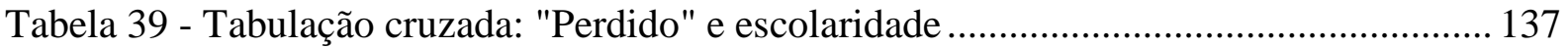

Tabela 40 - Tabulação cruzada: "Proteano Estável" e ano de Nascimento............................. 137

Tabela 41 - Tabulação cruzada: "Proteano Estável" e estado/cidade de residência................. 138

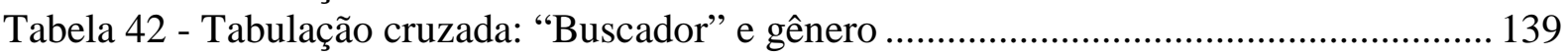

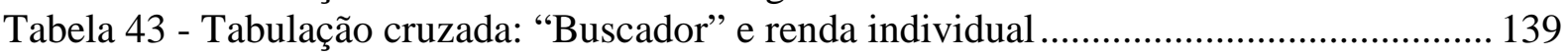

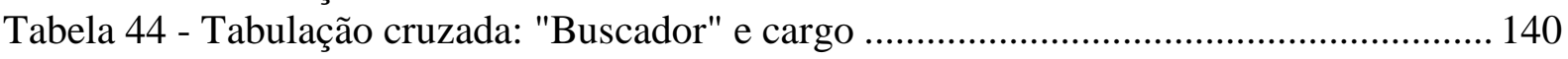

Tabela 45 - Tabulação cruzada: "Organizacional" e escolaridade ......................................... 140

Tabela 46 - Tabulação cruzada: "Organizacional" e renda individual ..................................... 141

Tabela 47 - Tabulação cruzada: "Organizacional" e presença de trabalho atual .................... 141

Tabela 48 - Tabulação cruzada: "Organizacional" e número de empregadores...................... 142

Tabela 49 - Tabulação cruzada: "Cidadão Sólido" e renda familiar ......................................... 143

Tabela 50 - Tabulação cruzada: "Cidadão Sólido" e presença de trabalho atual..................... 143

Tabela 51 - Tabulação cruzada: "Cidadão Sólido" e gênero .................................................... 144

Tabela 52 - Tabulação cruzada: "Contratado" e anos de experiência profissional ................. 144

Tabela 53 - Tabulação cruzada: "Arquiteto da Carreira Proteana" e ano de Nascimento...... 145

Tabela 54 - Tabulação cruzada: "Arquiteto da carreira proteana" e escolaridade .................. 146

Tabela 55 - Tabulação cruzada: "Arquiteto da carreira proteana" e estado civil .................... 146

Tabela 56 - Tabulação cruzada: "Arquiteto da Carreira Proteana" e renda individual ........... 146

Tabela 57 - Tabulação cruzada: "Arquiteto da Carreira Proteana" e renda familiar............... 147

Tabela 58 - Tabulação cruzada: "Arquiteto da Carreira Proteana" e presença de trabalho

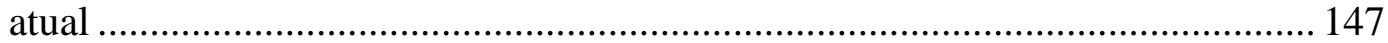

Tabela 59 - Tabulação cruzada: "Arquiteto da Carreira Proteana" e cargo ............................ 148 


\section{INTRODUÇÃO}

A nova geração que ingressa no mercado de trabalho observa uma realidade diferente das gerações anteriores. Com o advento da globalização, das novas tecnologias e do aumento da competitividade, o contrato psicológico de trabalho saiu de um modelo de emprego vitalício para um modelo de independência e autonomia. Neste novo contrato o ator de carreira é responsável pela gestão de sua carreira e pelo seu desenvolvimento (ARTHUR, 1994; HALL, 2002; DUTRA, 2010), mudando a relação entre empregador e empregado, logo as práticas de gestão de pessoas das organizações também sofrem alterações. Poucos estudos analisam o impacto dessas mudanças sobre indivíduos de diferentes gerações (LIPPMANN, 2008).

Indivíduos que vivenciaram eventos ou fatos históricos de grande relevância durante seu processo de socialização formam uma geração. A vivência compartilhada dá a essas pessoas a oportunidade de processarem esses acontecimentos de formas semelhantes, moldando seus valores e forma de pensar ao longo da vida (MANNHEIM, 1993). Considerando esse conceito, Dencker et al (2007) concluem que as experiências comuns de pessoas de idades semelhantes atuam como lentes que proporcionam um determinado foco através das quais os eventos são interpretados. Segundo os autores, o foco da lente difere entre gerações provendo diferentes respostas em suas interações atuais.

A geração é um atributo demográfico, ou seja, pode ser usada para categorizar os indivíduos. Como atributo demográfico, a geração é utilizada como base de comparação social, logo tem importância nas decisões, comportamentos e ações das pessoas (LAWRENCE; TOLBERT, 2007). Diferenças demográficas entre supervisores e subordinados, por exemplo, influenciam atitudes, comportamentos e desempenho no trabalho e quando essas características são diferentes das convenções sociais, geralmente problemas organizacionais emergem (COLLINS et al, 2009).

A demografia brasileira caminha para um aumento da população de jovens ingressando no mercado de trabalho e para um grande número de pessoas avançando para a idade de aposentadoria (IBGE, 2011). Essas mudanças demográficas geram desafios para as organizações e para a gestão de pessoas, tais como: a facilitação do ingresso dos jovens, a 
implementação de programas para aposentadoria e a implementação de programas para continuidade no mercado de trabalho de pessoas mais velhas. As mudanças também demandam das organizações a revisão de políticas, processos e práticas de gestão que visem à integração de grupos de diferentes idades e gerações (DENCKER et al, 2008; BENSON; BROWN, 2011; CAPELLI, 2005).

A pesquisa com enfoque geracional já consta no campo da Administração nos estudos de Marketing como uma forma de segmentação de mercado utilizando o conceito de coortes (IKEDA et al, 2008; PARRY; URWIN, 2010; PINHO et al, 2011), mas a discussão acadêmica sobre esse tema em gestão de pessoas é ainda embrionária, apesar do interesse crescente dos gestores da área (BENSON; BROWN, 2011).

Um tema geracional de destaque atualmente na mídia e nas organizações é a gestão dos jovens que estão ingressando no mercado de trabalho. Esses profissionais apresentam características distintas que por diversas vezes entram em conflito com o modo tradicional de trabalho nas organizações. Eles chegam com habilidades tecnológicas acima do esperado e demandas diferentes em termos de velocidade de aprendizado e carreira (LIPKIN; PERRYMORE, 2010; TAPSCOTT, 2010; LOMBARDIA et al, 2008), aspectos que fazem com que os gestores e as organizações necessitem de adaptações para a atração e retenção desses profissionais.

Esses jovens nascidos a partir de 1981 são classificados como Geração Y, título que demonstra a diferença das gerações anteriores, a Geração X, dos nascidos entre 1961 e 1980, e da geração dos Baby Boomers, nascidos entre 1945 e 1960, de acordo com classificação proposta por Amaral (2004) para o Brasil.

Diversos aspectos culturais, sociais e políticos trazem diferenças para essas gerações. A geração Y tem como principal aspecto que a distingue das demais o fato de ter crescido em um ambiente digital (com a presença de computadores, celulares, internet, etc.) e, por esse motivo, Tapscott (2010) a chama de Geração Internet. A tecnologia faz parte do dia a dia dessa geração, ela é a geração da velocidade e da variedade.

Os Ys são individualistas e agem a partir de suas convicções (LIPKIN; PERRYMORE, 2010; LOMBARDIA et al, 2008). Normalmente são filhos únicos e de pais que trabalham e não 
conseguiram encontrar um equilíbrio adequado entre vida profissional e familiar, o que faz com que esses jovens priorizem este equilíbrio em suas decisões (LOMBARDIA et al, 2008). Seu contato com a tecnologia, vídeo games e a internet fez com que eles desenvolvessem habilidades para lidar com essas ferramentas. Estão adaptados a uma resposta imediata e são focados nos resultados, pois entendem que as mudanças são contínuas e a informação expira rápido.

As respostas, além de rápidas, também podem vir de qualquer lugar a qualquer momento. Como cresceram em um mundo globalizado, os Ys o percebem como um coletivo social independente de origem cultural, racial ou geográfica. Os laços profissionais ou gostos pessoais são os fatores de formação de redes de contato. Eles costumam falar mais de um idioma, ter alto nível de instrução, ter alta mobilidade, buscam carreiras brilhantes e altos salários, mas sempre levando em consideração o equilíbrio com sua vida pessoal e com seus objetivos pessoais (LIPKIN; PERRYMORE, 2010). A geração Y busca no trabalho fonte de satisfação e aprendizado equilibrados com aspectos da vida pessoal, valorizando seu estilo de vida e vendo o trabalho como desafio e diversão (VASCONCELOS et al, 2009).

Atualmente existe uma discussão sobre a existência de diferentes gerações, ou seja, os jovens da geração $\mathrm{Y}$ agem dessa forma porque são jovens ou porque são realmente diferentes dos jovens de outras gerações? Nesse momento, as opiniões se dividem e especialistas, pais e professores se colocam de forma particular, baseados em suas próprias experiências pessoais e profissionais com indivíduos de diferentes gerações. Há pesquisadores e especialistas que defendem que sim, existem diferenças significativas entre indivíduos de diferentes gerações que justificam o uso desse conceito, tais como, Tapscott (2010), Lipkin e Perrymore (2010) e Amaral (2004). Enquanto existem pesquisadores que atestam que não se pode afirmar a existência dessas diferenças, tais como Jean Pralong (PRALONG, 2010).

A definição de gerações pode ser vista como uma tentativa de uma generalização de uma realidade, assumindo que todos os indivíduos de uma geração possuem as características descritas na literatura. É importante esclarecer que essa pesquisa busca estudar as características sugeridas pela teoria de Gerações, mas também considera a variabilidade decorrente da singularidade de cada indivíduo. Daí a importância da utilização do método científico que apoia o pesquisador no aprofundamento do conhecimento sobre o tema e na 
busca de uma explicação que considere o que é comum e o que é individual na população estudada.

Existe um aumento significativo da literatura acadêmica internacional sobre o assunto e a literatura nacional começa a tratar o tema nos últimos anos. $\mathrm{O}$ uso de bibliografia internacional para explicar as gerações no Brasil deve ser realizado com cautela, dado que indivíduos de diferentes países vivem momentos históricos, sociais, econômicos e culturais distintos, o que pode interferir nas características e separações entre gerações (PARRY; URWIN, 2010; UNITE et al, 2012).

Observando por um ponto de partida diferente, Bauman (2004) descreve o momento pósmoderno, que ele chama de "modernidade líquida", em que todos os relacionamentos são fluídos e frágeis, influenciados pela velocidade, superficialidade e mudanças constantes. Bauman relata que essa "modernidade líquida" afeta a todos os indivíduos igualmente, mas os nascidos nesse ambiente têm essa realidade como única existente, pois eles não vivenciaram outras formas de se relacionar e viver.

A realidade "líquida" permeia também as relações de trabalho. Os indivíduos "nativos" dessa realidade, ou seja, as novas gerações, e os indivíduos que hoje se deparam com ela, as antigas gerações, reagem de diferentes maneiras em relação à forma como percebem seu trabalho e se posicionam profissionalmente. Conforme descreve Veloso et al (2011) “embora seja essencial considerar as diferenças individuais de cada ser humano, não é impróprio cogitar que as pessoas de uma mesma geração compartilhem expectativas, desejos e percepções sobre o trabalho e sobre o papel das organizações laborais em suas vidas”.

Arthur (1994) e Hall (2002) buscam reposicionar o conceito de carreira dentro deste ambiente moderno relatando principalmente indicadores sociais e econômicos que compõe essa nova realidade, tais como, a descentralização da força de trabalho de grandes organizações para organizações menores, a redução de níveis hierárquicos e da autoridade e o crescente número de movimentações de indivíduos entre organizações. Os autores analisam o impacto dessa realidade na gestão de carreiras e na própria definição de carreira, trazendo aspectos relacionados à mobilidade, a busca de um sentido para o trabalho e a busca do sucesso psicológico. 
Arthur (1994), perante esse cenário, propõe o conceito de carreira sem fronteiras destacando a mobilidade física e psicológica, ou seja, o interesse em movimentar-se entre empregadores e a atitude geral de trabalhar além das fronteiras organizacionais, dos atores de carreira como resposta ao ambiente e também influenciando o ambiente.

Hall (2002) também propõe uma nova teoria de carreira chamada carreira proteana em que destaca a prioridade dos indivíduos em fazer escolhas de carreira relacionadas a seus valores pessoais e na autogestão de sua carreira. Juntos Arthur e Hall, trazem os alicerces para as pesquisas das novas carreiras.

Todos os indivíduos que, atualmente, vivem o mundo do trabalho, estão inseridos, em maior ou menor grau, nesse ambiente pós-moderno, ou na "modernidade líquida", e se deparam com novas questões relacionadas à suas carreiras. A questão que o tema "geração" coloca às carreiras é se estas são afetadas pelas diferentes gerações de forma equivalente ou não.

Considerando que um grande volume de discussão é gerado dentro das organizações, é possível estudar a diferença entre gerações especificamente no ambiente de trabalho, observando principalmente o campo em que exige um grande esforço de mediação entre indivíduos e organização - a gestão de carreiras. Entende-se que se existem diferenças entre gerações, esses indivíduos têm expectativas e atitudes diversas em relação a suas carreiras e, consequentemente, as organizações devem adotar estratégias e perspectivas para assumir sua função de mediação dessa variedade de expectativas. Dessa forma, a organização pode desenvolver, de forma efetiva, sua função de atração e retenção de talentos que garantirá sua produtividade e lucratividade no longo prazo.

Tendo em vista a entrada no mercado de trabalho de um grande contingente de trabalhadores da Geração Y e a repercussão pública sobre esses indivíduos, esse estudo explora a diferença entre gerações no ambiente de trabalho focando especificamente na Geração Y e suas atitudes de carreira. O objetivo da presente pesquisa é identificar o perfil de carreira da Geração Y. O perfil de carreira agrupa os indivíduos de acordo com a presença de atitudes modernas de carreira. A explicação das atitudes de carreira serão detalhadas no capítulo 3, que trata da revisão da literatura. 
Logo, esse estudo tem como pano de fundo a nova economia ou "modernidade líquida". Examina as novas abordagens de carreira que esse cenário estimula e as respostas da geração Y a esse ambiente quanto às suas atitudes de carreira. A ilustração 1 demonstra o objeto de estudo e as abordagens que o sustentam nessa dissertação.

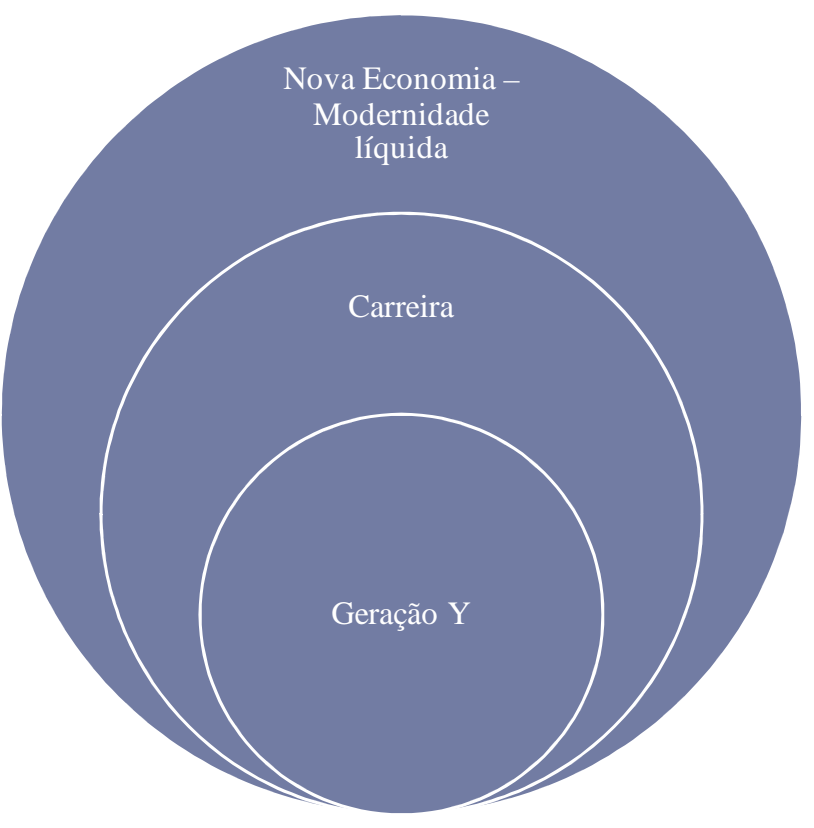

Ilustração 1 - Abordagens que sustentam o tema de pesquisa

Espera-se contribuir, dessa forma, para a avaliação da incorporação de atitudes de carreiras modernas entre os indivíduos pesquisados e observar se indivíduos mais jovens tendem a adoção de atitudes relacionadas às novas carreiras, como sugere a teoria de gerações. $\mathrm{O}$ entendimento das atitudes de carreira dos jovens contribui para o aprimoramento do tema gestão de pessoas e gestão de carreiras no Brasil e para a criação de abordagens de carreira e metodologias de desenvolvimento profissional específicas para a realidade nacional.

Considerando que apenas uma geração é escolhida como objeto de estudo, a primeira limitação de pesquisa é apresentada. Não será possível comparar os perfis de carreira de indivíduos de diferentes gerações ou avaliar diferenças entre gerações. O estudo de apenas uma geração é sugerido por Parry e Urwin (2010) como uma solução para aprofundamento do tema, de modo a evitar erros metodológicos de estudar a comparação entre gerações sem excluir efeitos de idade e do período. A abordagem comparativa pode orientar estudos futuros sobre o tema. 
Esta dissertação está organizada em seis capítulos, conforme mostra a ilustração 2.

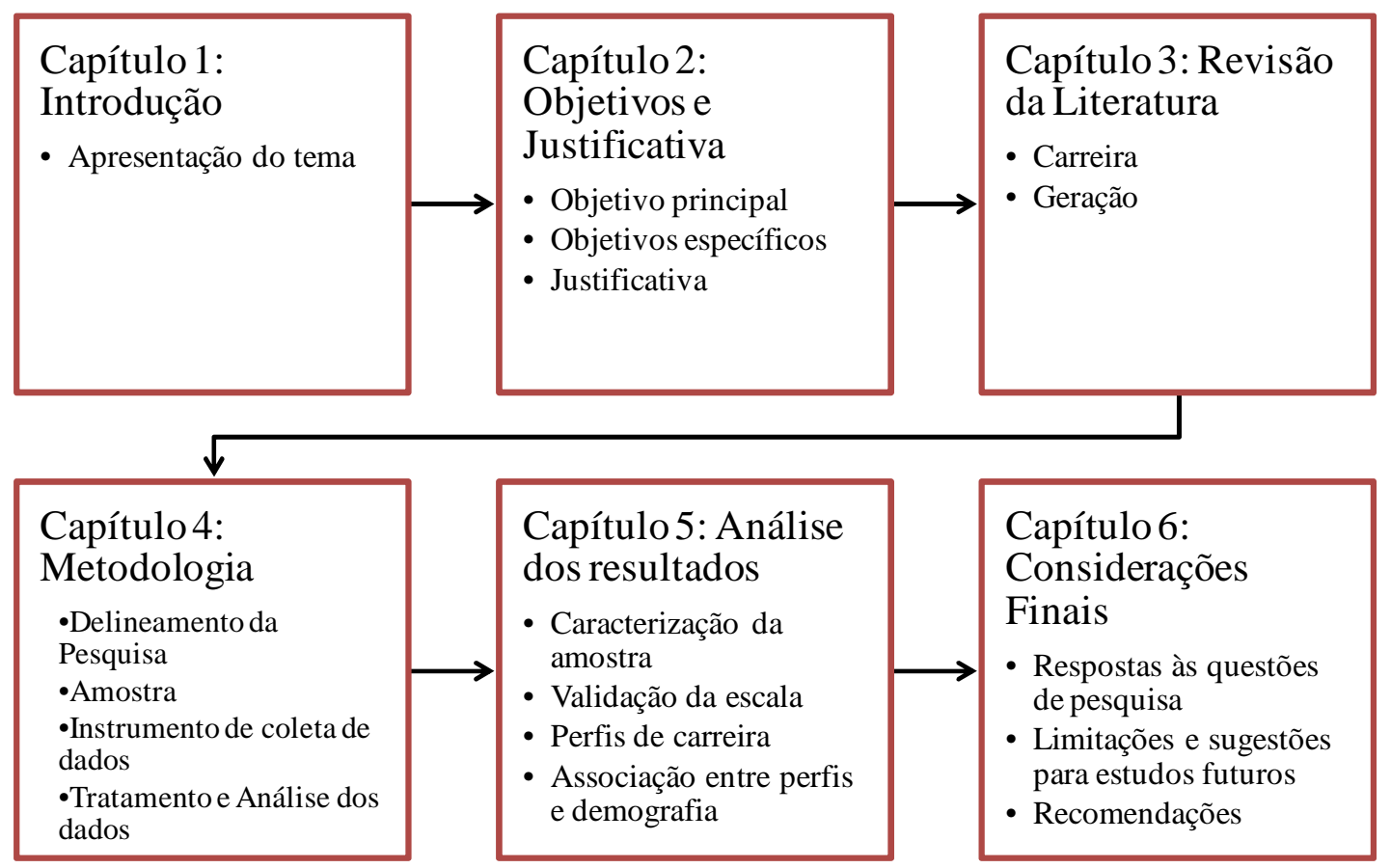

Ilustração 2 - Capítulos da dissertação

No próximo capítulo serão abordados os objetivos de pesquisa e a justificativa. 


\section{OBJETIVOS E JUSTIFICATIVA DE PESQUISA}

\subsection{Objetivos}

Como descrito no capítulo introdutório, essa dissertação busca entender de qual forma indivíduos da Geração Y percebem e se posicionam em relação a suas carreiras. Ela se encontra no campo de Gestão de Pessoas, no assunto de Carreira e o tema selecionado foi o perfil de carreira dos indivíduos da Geração Y.

Pode-se descrever o objetivo geral da seguinte forma: Identificar os perfis de carreira dos indivíduos da Geração Y no Brasil.

A base teórica de carreiras e dos perfis de carreira será constituída pelas teorias modernas de carreira, principalmente a de carreiras sem fronteiras e carreira proteana (ARTHUR, 1994; HALL, 2002; BRISCOE; HALL, 2006). O perfil de carreira é formado por uma combinação da maior ou menor presença de atitudes de carreira proteana, representada por duas escalas de mensuração: autodirecionamento de carreira e orientação a valores; e de atitudes de carreira sem fronteiras também representada por duas escalas de mensuração: mobilidade física e mobilidade psicológica, conforme proposto por Briscoe et al (2006).

Para atingir o objetivo geral da pesquisa e gerar a contribuição esperada para esse campo do conhecimento, faz-se necessário atender os seguintes objetivos específicos:

- Validar as escalas de atitudes de carreira sem fronteiras e proteana para a amostra estudada;

- Classificar os indivíduos da Geração Y em perfis de carreira, conforme suas atitudes de carreira;

- Investigar a influência das características demográficas e profissionais nas atitudes de carreira;

- Investigar a influência das características demográficas e profissionais nos perfis de carreira encontrados. 
O primeiro objetivo específico tem como função a validação do instrumento de coleta para a amostra estudada. Essa validação foi realizada no Brasil por Silva (2009) junto a uma amostra de 516 estudantes de Minas Gerais. Silva (2009) traduziu e validou semanticamente a escala proposta por Briscoe et al (2006). A nova validação tem como objetivo confirmar os achados de Silva perante uma amostra maior e garantir a validade para o presente estudo. Futuros estudos podem utilizar as escalas validadas para novas pesquisas, estimulando a produção do conhecimento nacional em carreiras.

O uso da escala proposta por Briscoe et al (2006) seguido da classificação proposta por Briscoe e Hall (2006) é inovadora no Brasil. Foram encontrados estudos que utilizaram o instrumento de pesquisa e estudos que utilizaram os perfis de carreira, mas não foi encontrado nenhum estudo que utilizou os dois em conjunto. $\mathrm{O}$ uso desses instrumentos associados pode estimular a produção de estudos comparativos no futuro.

A investigação da influência das características demográficas e profissionais nas atitudes e perfis de carreira tem uma função descritiva. Espera-se aprofundar o conhecimento da associação entre as variáveis demográficas e as atitudes e perfis na amostra de jovens da Geração Y analisada.

A teoria de gerações e um estudo anterior conduzido em outros países (UNITE et al, 2012) indicam que indivíduos da Geração $\mathrm{Y}$ tem alta predominância de atitude de carreiras modernas, uma vez que eles são nativos desse novo contexto social e tecnológico. Apesar desses indícios, faltam pesquisas empíricas sobre essa relação entre gerações e as carreiras modernas no Brasil. O presente estudo visa explorar esse campo de pesquisa.

\subsection{Justificativa}

Enquanto a pesquisa sobre diferenças etárias no trabalho tem crescido nos últimos anos, ainda existe pouco conhecimento sobre como as diferentes gerações percebem suas carreiras. Com o aumento da diversidade etária nas organizações, menores barreiras globais e a necessidade das organizações de atrair, reter e motivar pessoas talentosas, é mais importante do que nunca entender como os indivíduos percebem suas carreiras em todas as idades e gerações. É 
também importante analisar como isso se diferencia entre os vários países (BRISCOE et al, 2012).

Um primeiro aspecto relevante a se considerar é o fato de a bibliografia atual sobre gerações ser predominantemente norte-americana (UNITE et al, 2012), existindo poucos estudos sobre as diferenças entre as gerações no Brasil. Como inúmeras publicações nacionais em veículos de cunho comercial têm abordado o tema em artigos com referência a publicações estrangeiras e entrevistas com especialistas em organizações brasileiras, conclui-se que o assunto tem despertado interesse crescente dos profissionais de RH e dos gestores que enfrentam no dia a dia as dificuldades de gestão de suas equipes multigeracionais. Pesquisas nacionais sobre gerações podem garantir as bases conceituais para a evolução dessas discussões no Brasil.

A Society for Human Resource Management (SHRM) em uma de suas pesquisas de tendências em Gestão de Pessoas feitas com profissionais de RH do mundo todo apontou como três das dez tendências mais importantes do mercado de trabalho global para 2011: a questão de envelhecimento da população, a saída dos Baby Boomers do mercado de trabalho e o aumento dos custos de saúde devido ao envelhecimento da população. É importante levar em consideração que os principais países investigados estão na América do Norte e Europa, e possuem uma pirâmide etária diferente da brasileira, sendo que a população idosa representa uma parcela significativa da população nesses países (SHRM, 2011).

No Brasil, os dados do censo demográfico de 2010 realizado pelo IBGE (2011) posicionam a década de 80 como os anos iniciais da intensificação da tendência de envelhecimento da população brasileira. Logo, hoje e nos próximos dez anos haverá um grande número de pessoas que ingressarão no mercado de trabalho e, após isso, será observada uma tendência de queda. Esse é o chamado bônus demográfico, onde o país tem maior possibilidade de desenvolvimento econômico e social, pois muitas pessoas podem trabalhar e menos pessoas dependem da produção das que trabalham (DIEESE, 2011). A entrada dessa geração no mercado de trabalho e a efetividade dessa mão de obra são importantes para o aproveitamento desse momento histórico e para o crescimento do país em longo prazo.

A questão da integração das diferentes gerações no trabalho desponta como o quinto tema mais relevante entre as tendências para a Gestão de Pessoas em 2015 de acordo com a 
pesquisa de Tendências em Gestão de Pessoas nas Empresas Brasileiras, conduzida pela FIA (Fundação Instituto de Administração) em 2010. Nessa pesquisa foram consultados profissionais de $\mathrm{RH}$, acadêmicos e consultores. O envelhecimento da força de trabalho apareceu em uma primeira rodada da pesquisa, mas não se firmou como tema emergente na segunda rodada (FISCHER; ALBUQUERQUE, 2011).

Com base nesses dados, é possível verificar a importância do estudo acadêmico das questões geracionais atuais e seus impactos na Gestão de Pessoas no Brasil. As organizações, representadas por seus líderes, gestores e profissionais de RH reconhecem a dificuldade em entender os motivos e anseios da nova geração e como fazer para atrair e retê-los, pois se trata de um grupo com um nível de independência alto, grandes ambições de carreira e salário e que exige alta flexibilidade e informalidade no ambiente de trabalho (LIPKIN; PERRYMORE, 2010; TAPSCOTT, 2010). Perante as diferentes exigências das diversas gerações, é necessária uma mudança significativa nas relações entre organização e empregado, que passa desde códigos de vestimenta até programas de incentivo.

Conhecer a Geração Y, seu perfil e suas expectativas de carreira é fundamental para compreender para qual direção as práticas de Gestão de Pessoas seguirão já que esse é o grupo que em breve será maioria e ocupará as posições de liderança. Em 2011, os jovens de até 29 anos eram responsáveis por 40,3\% dos vínculos de trabalho ativos no Brasil (DIEESE, 2011). Entender o perfil de carreira desses jovens e as respostas das organizações a essas novas demandas é relevante para a análise da gestão de carreiras nas organizações brasileiras. A compreensão da mudança do perfil dos atores organizacionais traz à discussão os desafios atuais e as necessidades futuras que poderão surgir nos próximos anos.

O mapeamento dos perfis de carreira desses jovens esclarece como eles veem sua própria carreira e quais atitudes e orientações são preferenciais, possibilitando a implementação de ações de desenvolvimento de carreira individuais (BRISCOE; HALL, 2006). A identificação dos perfis também permite que as organizações criem soluções adequadas aos jovens, através da revisão de seus processos, programas de desenvolvimento, planos de remuneração e benefícios, políticas de carreira e planos de retenção.

As teorias das novas carreiras são recentes e diversos estudos têm sido realizados, principalmente nos Estados Unidos e Europa. No entanto, ainda existe a necessidade de 
verificação empírica de seus conceitos inclusive nesses países (RODRIGUES; GUEST, 2010), logo pesquisadores recomendam a realização de estudos empíricos sobre as novas carreiras e sobre a análise dos impactos dos potenciais fatores influenciadores das mesmas, tais como, idade, gênero, escolaridade, etc. (BRISCOE et al, 2006; SEGERS et al, 2008; SILVA et al, 2011).

Espera-se com esse estudo também contribuir para o aprofundamento dos estudos teóricos do tema gestão de carreiras no Brasil. A discussão sobre carreira é relativamente recente no país, já que se iniciou na década de 90 e, ainda hoje, observa-se escassez de literatura nacional sobre o assunto (VELOSO, 2009). 


\section{REVISÃO DA LITERATURA}

Considerando o problema de pesquisa proposto, a revisão da literatura apresenta dois eixos principais: Carreira e Gerações. Os referenciais teóricos relacionados a esses temas serão apresentados separadamente. Na síntese da revisão da literatura, apresentada no final desse capítulo, essas teorias serão analisadas em conjunto propondo a base teórica para o estudo aqui exposto.

\subsection{Carreira}

\subsubsection{Conceito de carreira}

De acordo com Hall (2002, p. 12): “A carreira é a sequência individualmente percebida de atitudes e comportamentos associados com experiências e atividades relacionadas ao trabalho durante a vida de uma pessoa." 1

Antes dessa, diversas definições de carreira foram propostas considerando a forma como a carreira era vista e trabalhada em diferentes momentos históricos. Apesar de teóricos investigarem o como e os porquês das ocupações individuais e trajetórias de vida por séculos, foi no século XX que o termo "carreira", como curso de vida profissional, surgiu na literatura sociológica e psicológica (MOORE et al, 2007).

Os trabalhos iniciais sobre carreira tiveram foco em implicações práticas e intervenções que se faziam necessárias. Diversos trabalhos surgiram durante a $2^{\circ}$ Guerra Mundial, onde as forças armadas resolviam problemas de escassez de recursos humanos por processos rigorosos

\footnotetext{
1 "The career is the individually perceived sequence of attitudes and behaviors associated with work-related experiences and activities over the span of the person's life"
} 
de seleção e testes vocacionais baseados em técnicas de avaliação individual, tais como testes de aptidão e de QI que usavam a análise estatística para avaliar milhares de pessoas.

A abordagem vocacional continuou no pós-guerra e permeou as organizações que buscavam uma força de trabalho estável e especializada e que privilegiavam a relação de longo prazo entre empregado e empregador. Em contrapartida, as organizações ofereciam incentivos e planos de carreira para aqueles que demonstravam lealdade. Essa abordagem ligava traços de personalidade a determinadas carreiras, com uma visão da pessoa adequada para cada tipo de trabalho. Diante desse cenário, o ator de carreira era passivo e trilhava os passos traçados pela organização. A imagem da boa profissão era aquela que trazia estabilidade e respeito pelas habilidades e experiência desenvolvidas na função (ARTHUR et al, 1999).

Como complemento a abordagem vocacional, surgiu a abordagem da gestão de recursos humanos procurando acomodar ideias de "potencial humano". A abordagem da gestão de recursos humanos enfatizava o sistema de carreira, promovendo uma forma de relacionar responsabilidades consistentes com as habilidades das pessoas e, dessa forma, promovia carreiras aceleradas (ARTHUR et al, 1999).

Em ambas as abordagens, a visão é de que a carreira era uma sucessão de trabalhos relacionados ajustados em uma hierarquia de prestígio, por meio do qual as pessoas se movem em uma sequência ordenada e, na maioria das vezes, previsível (ARTHUR et al, 1999).

Uma nova abordagem foi proposta por teóricos desenvolvimentistas, que focaram a carreira como entidades orgânicas com ciclos de vida em contínuo desenvolvimento, que são modelados por interações complexas entre decisões pessoais e forças externas vindas da família, da sociedade, da economia e das organizações (ARTHUR et al, 1999). Iniciou-se um consenso de que o indivíduo continua a se desenvolver ao longo de sua carreira. Logo, a visão da abordagem vocacional de que o indivíduo poderia ser alocado a uma posição estática foi substituída por um entendimento mais dinâmico da carreira individual (MOORE et al, 2007). Essa última abordagem teve uma influência importante nas teorias modernas de carreira que serão detalhadas posteriormente. 
Nos anos 70, Lotte Bailyn, Douglas Hall, Edgar Schein e John Van Maanen produziram três livros seminais da teoria contemporânea de carreira que trouxeram importantes contribuições ao tema, válidas entre as diversas teorias de carreira (ARTHUR, 1994):

a) $\mathrm{O}$ conceito de carreira é universal e pode ser aplicado a todas as pessoas em todas as organizações;

b) O tempo é uma dimensão que deve ser considerada como mediadora-chave no relacionamento entre indivíduo e organização;

c) A carreira deve ser analisada com um enfoque multidisciplinar, envolvendo psicologia, sociologia, antropologia, ciências políticas, economia, etc.

d) A carreira deve ser analisada tanto na perspectiva objetiva quanto na subjetiva.

Hall (2004) descreve quatro diferentes significados de carreira. Os dois primeiros estão mais relacionados ao senso comum e são mais conhecidos de forma geral e os dois últimos surgem das ciências sociais:

a) Carreira como avanço: ligada a noção de mobilidade vertical ou crescimento na hierarquia. Nesse sentido, carreira representa a sequência de promoções e outras movimentações ascendentes em uma estrutura hierárquica de trabalho durante a vida de uma pessoa. Existe um conceito de direcionalidade, ou seja, para cima é bom, para baixo é ruim.

b) Carreira como profissão: certas ocupações representam carreiras, enquanto outras não. As ocupações que representam carreiras apresentam geralmente um padrão claro de avanço sistemático em posições correlacionadas.

c) Carreira como uma sequência de trabalhos ao longo da vida: a carreira é a série de posições ocupadas, independente da profissão ou nível, ao longo da vida de trabalho de uma pessoa.

d) Carreira como uma sequência de experiências relativas a funções ao longo da vida representando a experiência pessoal decorrente da sequência de trabalhos e atividades que constitui a história de trabalho do indivíduo. É a carreira subjetiva, que trata de aspirações, satisfações, autoconceitos e outras atitudes da pessoa em relação a sua vida e trabalho. É possível até mesmo considerar a carreira independente do trabalho de acordo com essa definição, pois ela fala de funções ou papéis vividos não necessariamente de trabalho. 
Para construir a definição de carreira proposta no início desse capítulo, Hall (2004) coloca as seguintes premissas:

- Carreira em si não implica em sucesso ou fracasso ou avanços rápidos ou lentos. O objetivo é entender o que acontece durante o processo da carreira de um indivíduo.

- Sucesso ou fracasso de carreira é avaliado pelo autor da carreira ao invés de terceiros. Cada um é responsável pelas suas próprias escolhas. A escolha pessoal é um elemento chave no desenvolvimento de carreira.

- Carreira é composta por comportamentos e atitudes. Tanto a visão objetiva (escolhas observáveis) quando a visão subjetiva (mudanças em valores, atitudes e motivações) devem ser consideradas para um amplo entendimento da carreira de um indivíduo.

- A carreira é um processo - uma sequência de experiências relacionadas ao trabalho. $\mathrm{O}$ conceito de carreira como profissão ou como avanço são muito limitantes e o conceito de carreira como vida é muito amplo. O foco é no trabalho e cenário organizacional, mas o trabalho não precisa ser remunerado e formal. Essa definição fica no meio do caminho entre o conceito de carreira como sequência de trabalhos e o conceito de carreira como sequência de experiências de vida.

\subsubsection{Gestão de carreira pela organização}

As mudanças cada vez mais rápidas e profundas nas organizações decorrentes de transformações tecnológicas e econômicas e do aumento da competição e da intensificação da globalização trazem impactos significativos para a Gestão de Pessoas e para a gestão de carreiras.

Com a evolução do modelo de gestão das organizações de um modelo de controle para um modelo de comprometimento, as organizações modernas tiveram que rever todo o seu sistema de Gestão de Pessoas de modo a garantir comprometimento de seus empregados e realizar sua estratégia organizacional (ALBUQUERQUE, 1999).

O modelo de comprometimento traz a visão de que as pessoas são parceiras no atingimento dos objetivos da organização e, por isso, busca o comprometimento dos empregados com a instituição para aumento do desempenho. As práticas de RH, decorrentes da estratégia de 
Gestão de Pessoas, veem no sentido de promover o comprometimento. Dentre as práticas de $\mathrm{RH}$, encontram-se as práticas de carreira, que são fundamentais para que exista uma mediação entre os interesses da organização e do empregado, de forma que o contrato psicológico seja continuamente revisto e ao mesmo tempo preservado, garantindo a percepção de justiça entre as partes.

O contrato psicológico consiste em crenças individuais modeladas pela organização, relativa aos termos de troca entre o indivíduo e a sua organização. Ele possibilita a indivíduos e organizações serem mais produtivos, já que torna os comportamentos previsíveis e permitem a coordenação de esforços e planejamento. Alguns fatores chave são o entendimento e aceite de livre vontade dos termos do contrato e a percepção de mutualidade (ROUSSEAU, 1995).

Dentro dos modelos organizacionais antigos, baseados no controle, as relações de trabalho eram focadas no cargo, na especialização, na tarefa e na hierarquia. A organização era responsável pela carreira de seus empregados e o empregado, em contra partida à gestão de sua carreira, oferecia lealdade já que geralmente a carreira era desenvolvida em um único empregador (BIANCHI; QUISHIDA, 2009).

Com as mudanças econômicas, sociais e políticas da nova economia, as organizações tiveram que mudar sua forma de gerir as pessoas (ARTHUR, 1994; BARUCH, 2004). As organizações passaram a requerer maior flexibilidade, habilidade de lidar com a mudança constante e aprendizado contínuo sem oferecer a garantia da estabilidade (BARUCH, 2004; BIANCHI; QUISHIDA, 2009). Consequentemente, houve a quebra do antigo contrato psicológico de trabalho e a necessidade da criação de novos contratos. Nesses novos contratos os empregados oferecem longas horas, assumem responsabilidades adicionais, provem habilidades mais amplas e toleram mudanças e ambiguidade, enquanto empregadores oferecem remuneração mais alta, remuneração por desempenho e acima de tudo, o trabalho em si (BARUCH, 2004).

Hall (2002) destaca que a forma transacional do contrato psicológico ganhou maior peso, baseado em trocas utilitárias de curto prazo entre indivíduos e organizações em detrimento da forma relacional que se baseia no comprometimento mútuo e de longo prazo, ou seja, tanto empregado quanto empregador darão continuidade na relação apenas enquanto suas necessidades imediatas forem atendidas. 
Dutra (2010) aponta alguns sinais atuais desse novo contrato psicológico no Brasil, tais como: o aumento do número de pessoas dispostas a trocar remuneração por desenvolvimento, a criação e ampliação rápida de cursos de pós-graduação e da ideia de educação continuada, o aumento do número de indivíduos que fazem transição de carreira, demonstrando ciclos mais curtos de carreira e o aumento da importância da carreira subjetiva.

As novas teorias de carreira exigem novas abordagens de gestão de carreira pelas organizações, refletindo em sistemas de carreira dinâmicos. Apesar disso, grande parte da literatura moderna sobre carreira foi desenvolvida por psicólogos, privilegiando o ponto de vista individual (BARUCH; PEIPERL, 2000). Esse desenvolvimento aconteceu em departamentos de psicologia, educação e aconselhamento de carreira, onde os clientes não eram os gerentes e suas organizações, mas educadores e conselheiros de carreira que estavam mais interessados na carreira como projeto pessoal do que como um componente das organizações (INKSON, 2006).

Baruch (2004) busca trazer a perspectiva organizacional da nova carreira refletindo sobre o papel da organização, já que, na maioria dos casos, as organizações são o espaço onde as carreiras se desenvolvem e mais do que isso, organizações são sistemas de carreira. A partir da estrutura organizacional, que estipula as posições existentes e as relações entre essas posições, são definidas as trajetórias de carreira. As trajetórias de carreira indicam caminhos possíveis para os indivíduos percorrerem em seu desenvolvimento dentro da organização. As trajetórias se tornam ativas quando são definidos os requisitos de acesso e os mecanismos que permitem as pessoas trilharem essas trajetórias. Dessa forma, as organizações gerenciam as carreiras. Observando as carreiras modernas, os sistemas de carreira baseados em posições hierárquicas devem ser substituídos pelos baseados em qualificações, competências e experiências (VELOSO, 2009; DUTRA, 2010).

Baruch (2004) descreve a carreira organizacional como uma contínua renegociação de contratos psicológicos e destaca a importância da gestão de carreiras como papel principal de Recursos Humanos na sua função de atrair e reter talentos. Dutra (2010) vê a gestão de carreira pela organização como uma sequência de posições e trabalhos realizados pelo indivíduo articulada de forma a conciliar o desenvolvimento das pessoas com o desenvolvimento da empresa, também trazendo a função da mediação entre as partes como parte essencial do conceito. 
Baruch (2004) descreve a integração vertical como a base para a interação entre gestão de recursos humanos e a gestão estratégica da organização. Para ter uma atuação estratégica, inicia-se uma análise da estratégia de negócio para definição da estratégia de RH. Essas estratégias devem se comunicar continuamente e caminhar em paralelo, mantendo alinhamento e sinergia. A partir das estratégias de RH desenvolvem-se as práticas de RH que atendam a estratégia e também necessidades individuais dos empregados de modo a envolvêlos no intento estratégico definido. As práticas de gestão de carreiras são fundamentais para atender necessidades individuais e engajar os empregados com os objetivos organizacionais. Novas práticas devem ser aplicadas para transformar o intento estratégico em ações e iniciativas, encontrando novas formas de manter o relacionamento entre indivíduos e suas organizações.

O alinhamento estratégico ou integração do negócio foca no alinhamento de pessoas, processos e tecnologia com a estratégia em evolução da organização. Isso possibilita às organizações o aproveitamento de suas capacidades através da implementação de sua visão estratégica em uma abordagem sistemática. $\mathrm{O}$ alinhamento estratégico deve gerar uma alta efetividade organizacional e alto desempenho (BARUCH, 2004).

Para os indivíduos, o alinhamento estratégico oferece oportunidades de aprendizado e de desenvolver diversos caminhos de carreira já que existe um enriquecimento das competências e habilidades individuais (BARUCH, 2004).

O RH assume novos papéis com o alinhamento estratégico, no nível micro, ele sai da postura paternalista para uma abordagem consultiva e de planejamento conjunto. Em um nível macro, o executivo de RH lida com questões estratégicas de Gestão de Pessoas e com o alinhamento dessa estratégia com a estratégia organizacional (BARUCH, 2004).

Para definição das práticas de carreira, Baruch (2004) recomenda a análise da estratégia organizacional e de $\mathrm{RH}$, já que as práticas devem ser desenvolvidas e implementadas no sentido de realizar a estratégia estabelecida, e também a busca de melhores práticas no mercado que podem ajudar a criar ou manter um portfólio efetivo.

Arthur et al (2005) alerta sobre a importância da coerência entre as práticas de Gestão de Pessoas e os princípios das novas carreiras para evitar contradição ou confusão. Na migração 
para os novos modelos de carreira é essencial que os sistemas de remuneração, recompensa, promoção, benefícios, etc. deem suporte ao movimento.

De acordo com Bianchi e Quishida (2009), Dutra (2010), Baruch e Peiperl (2000), Veloso (2009), Hall (2002) e Hall et al (2012) são práticas importantes da gestão de carreira desenvolvidas pelas organizações:

- Suporte de carreira: através de programas de coaching, couselling e de mentoring, ferramentas de autoconhecimento, workshops de planejamento de carreira, recolocação em caso de demissão, programas de preparação para aposentadoria, etc. As organizações também podem criar centros internos de desenvolvimento ou suporte a carreira, envolvendo gestores, profissionais de $\mathrm{RH}$ ou consultores externos como possíveis facilitadores.

- Desenvolvimento de competências e aprendizado contínuo: através de capacitação formal, participação em grupos de trabalho, participação em decisão, movimentação dos profissionais, avaliações de desempenho, etc.

- Implantação de processos, políticas e práticas de gestão de carreiras: definir trajetórias de carreira possíveis com requisitos de acesso e comunicar esses requisitos, definir carreiras paralelas, desenvolver planos de sucessão, implantar programas de recrutamento interno, realizar movimentações laterais e job rotations.

- Desenvolvimento do grupo gerencial: através da preparação dos gestores para discutir assuntos relacionados à carreira com seus subordinados, de modo que eles construam uma relação de confiança e comunicação aberta, já que os gestores são os representantes da organização perante seus subordinados.

- Processo de transformação cultural: fortalecendo valores organizacionais alinhados à estratégia da organização, mantendo os empregados atualizados e sobre as necessidades e ambiente da empresa e oferecendo direcionamento.

- Alinhamento dos contratos de trabalho à nova realidade de gestão de carreiras: viabilizando novos contratos de trabalho que ofereçam opções flexíveis que atendam 
diferentes expectativas em termos de remuneração, benefícios, desenvolvimento, reconhecimento, etc.

- Implantação de canais de comunicação entre organização e empregado: instituindo mecanismos formais para as pessoas se colocarem e serem ouvidas, criando formas de conhecer as expectativas, experiências e habilidades dos empregados para viabilizar os itens anteriores.

- Desenvolvimento de redes internas e externas: incentivando a participação dos empregados em atividades extraorganizacionais e a formação de networks sociais.

Analisando organizações em seu processo de mudança diante do novo contrato, Hall (2002) classifica as empresas em três estágios de adaptação:

a) "Vivendo o trauma" ou "Perdida em Árvores": grupo de empresas que está sob instabilidade radical devido ao ambiente econômico. Os empregados ainda não veem a floresta ou o quadro completo, que é o novo contrato requerido pelo novo ambiente competitivo, mas vê as árvores, ou seja, as dificuldades nos negócios e as demissões em massa que afetam a lealdade e estabilidade.

b) "Vivendo o novo contrato" ou "Vê a Floresta": as empresas percebem a mudança drástica como passada e conhecem a natureza do novo contrato. Seus empregados trabalham sob o novo contrato com suas oportunidades de maior liberdade, responsabilidade e sucesso psicológico. O tempo é o principal fator que separa as organizações "perdidas em árvores" das que "veem a floresta".

c) "Aprendendo continuamente" ou "Confortável na Floresta": percebem a mudança de contrato como gradativa. Apesar de terem vivenciado alguma instabilidade financeira conseguiram superá-la mantendo sua competitividade através de sua liderança, alto engajamento de seus empregados e preservação de seus valores organizacionais. Desenvolveram uma habilidade de aprender continuamente.

Existem poucas pesquisas sobre o processo atual de gestão de carreira nas organizações (BARUCH, 2004). Dutra (2010) atribui essa escassez ao fato de a carreira estar vinculada à 
remuneração e, por isso, projetos e discussões sobre carreira teriam um impacto na massa salarial da empresa.

Os indivíduos, cada vez mais, percebem suas carreiras como governadas por suas próprias motivações e ações e as organizações já não possuem mais uma voz determinante ou um comando automático nessas decisões, logo as organizações devem considerar a opinião do empregado em processos de decisão. Isso faz com que o planejamento de carreira pela organização seja ao mesmo tempo crucial e difícil. Crucial porque a função de Gestão de Pessoas deve sincronizar as decisões de carreiras individuais com os objetivos organizacionais para garantir o desempenho organizacional. Difícil porque as decisões são individuais e baseadas em critérios pessoais o que torna o planejamento complexo. Isso faz com que aumente a necessidade de diálogo entre empregados e empregadores, já que os sistemas sofisticados de carreira e sucessão exigem estabilidade e previsibilidade que não são mais realistas (HALL et al, 2012).

Briscoe et al (2012) alertam que a pesquisa atual sobre carreira é desenvolvida dentro do paradigma universalista, ou seja, assume que indivíduos e organizações são idênticos em todo o mundo e que existe uma forma ideal de serem gerenciados. Esses autores argumentam que as organizações e os indivíduos são socialmente impactados pelo ambiente externo e cultura que vivenciam e isso faz com que eles se adaptem às estruturas e comportamentos vigentes para lidar com seus respectivos contextos. Dessa forma, propõem uma abordagem contextual para o estudo das carreiras ao redor do mundo destacando a cultura nacional como um elemento fundamental de diferenciação do modo como a carreira é percebida e gerenciada.

\subsubsection{Contexto das novas carreiras}

As teorias tradicionais de carreira foram desenvolvidas com foco na gestão de carreiras em grandes organizações, com estruturas hierarquizadas e operando em ambientes internos e externos estáveis (ARTHUR, 1994). Essas teorias foram construídas e atendiam o paradigma da era industrial, onde grandes organizações cresciam, produzindo riqueza e empregos que atendiam a necessidades individuais de longo prazo (ARTHUR et al, 1999). 
$\mathrm{Na}$ década de 80, o modelo das grandes organizações começou a declinar, a chave da competitividade passou a ser a inovação e competidores menores e mais flexíveis ganharam espaço. Esse novo cenário social e econômico foi chamado de Nova Economia (ARTHUR et $a l, 1999$ ) ou Economia do Conhecimento (FORAY; LUNDVALL, 1996).

A Nova Economia foi marcada por diversos movimentos nas organizações, tais como, downsizing, reengenharia, novas tecnologias da informação, globalização e aumento da competição, implicando no desenvolvimento de formas mais flexíveis e horizontais de organizar o trabalho. Para serem competitivas as organizações precisavam ser menores e mais ágeis diante das mudanças do mercado que se tornaram frequentes. Duas qualidades principais dessas transformações podem ser apontadas: velocidade e complexidade (HALL, 2002).

A Economia do Conhecimento tem duas características principais, a primeira é que a competência humana é o centro do desenvolvimento social de qualquer sociedade e a segunda é que a economia é mais fortemente e mais diretamente baseada na produção, distribuição e uso do conhecimento do que no passado (FORAY; LUNDVALL, 1996).

Quinn (1992) após análises de pesquisas e entrevistas com mais de 100 presidentes e diretores de grandes organizações chamou as organizações que operam com sucesso na economia do conhecimento de "negócios inteligentes" (intelligent enterprises). Ele define "negócios inteligentes" como organizações que convertem recursos intelectuais em uma cadeia de entrega de serviços, integrando-os da melhor forma para certos clientes. Esse conceito é baseado na grande e crescente participação do setor de serviços no PIB (produto interno bruto) norte-americano e de outros países e nos impactos da globalização, das novas tecnologias e na importância que o conhecimento vem assumindo como gerador de valor nas organizações.

Esse cenário gera a necessidade de um novo modo de repensar as carreiras. Os empregados dos "negócios inteligentes" também precisavam ser mais flexíveis, ágeis e capazes de lidar com maior complexidade.

Diversos impactos no mercado de trabalho podem ser apontados como decorrentes da Nova Economia, tais como, a redução do tempo de empresa, menor estabilidade de emprego, 
descentralização das organizações, maior mobilidade das pessoas entre empregadores, aumento do contingente de mão de obra temporária e com diferentes vínculos de trabalho (empreendedores, consultores, etc.) (ARTHUR, 1994; HALL, 2002).

Os limites entre o interno e externo a organização se dissolveram, empregados de níveis mais baixos na hierarquia ganharam mais poder, descrições de cargo e hierarquias de status foram substituídas por mediações informais de oportunidades de contribuir. A nova força de trabalho feminina apaga as barreiras entre trabalho e vida pessoal e encontra formas de integrar papéis sociais que antes eram separados (ARTHUR et al, 1999).

Existem novos acordos de reciprocidade em jogo. Reciprocidade pode ser definida como os laços que conectam os atores de carreira a seus empregadores e vice-versa. Além dos acordos formalmente estabelecidos que geralmente envolvem benefícios e retornos tangíveis, existe o contrato psicológico entre empregador e empregado que envolve aspectos intangíveis da relação. Por exemplo, o empregador tem uma expectativa de esforço discricionário por parte do empregado e o empregado tem uma expectativa de uma remuneração justa, um trabalho interessante, autonomia e realização sendo oferecidas pelo empregador. Para cumprir esse contrato psicológico, ambos os lados precisam se engajar (ARTHUR et al, 1999).

Esse movimento de mudança nas expectativas e na forma do indivíduo encarar a carreira é gerado pelo medo de demissão, promessas não cumpridas e pela busca de empregabilidade. Nesse contexto, as pessoas são incentivadas a buscar conceitos espirais e não lineares de carreira, separando o trabalho feito e o aprendizado gerado (ARTHUR, 1994).

O aprendizado passa a ser um elemento chave na gestão da carreira. Quando mais se aprende, maior a empregabilidade. Os melhores empregos são os que proporcionam aprendizado e não necessariamente estabilidade. Nesse contexto, a carreira é vista como um repositório de conhecimento e uma fonte de diferenciação da organização (ARTHUR, 1994).

A partir desse contexto, surgiram duas abordagens para se pensar as novas carreiras: a abordagem proposta por Douglas Hall, chamada de carreira proteana, e a abordagem proposta por Michael Arthur, chamada de carreira sem fronteiras. Ambos os autores partem das mudanças descritas, advindas da Nova Economia para desenvolver seus constructos. 


\subsubsection{Carreira sem fronteiras}

O conceito de carreira sem fronteiras surgiu a partir do conceito de "organização sem fronteiras" de Jack Welsh, CEO da General Electric. Jack Welsh descreveu a "organização sem fronteiras" como um contraponto à organização tradicional e formal. Em 1993, a Academy of Management escolheu a "organização sem fronteira" como tema para sua conferência atraindo o simpósio "carreira sem fronteiras". O simpósio se tornou um tema especial do Journal of Organizational Behavior, em 1994, e esses artigos foram expandidos para um livro chamado "Boundaryless Career", editado por Michael Arthur e Denise Rousseau e publicado em 1996 (INKSON, 2006).

Michael Arthur foi influenciado por Welsh, com seu conceito de "organização sem fronteiras", por Quinn, por meio de seu livro "Intelligent Enterprise" e pelo novo paradigma da economia do conhecimento (ARTHUR, 1994; ARTHUR et al, 1995), no desenvolvimento da sua teoria de carreira. A indagação sobre como os princípios de carreira mudariam para que os indivíduos se adaptassem a essa nova realidade fez com que o pesquisador definisse o conceito de carreira sem fronteiras (boundaryless career).

Arthur e Rousseau (1996) definem a carreira sem fronteiras como antônimo de carreira organizacional ou da carreira desenvolvida em um único espaço organizacional. $\mathrm{O}$ termo sem fronteiras surge por diversos motivos:

- $\mathrm{O}$ ator de carreira move-se através das fronteiras de diferentes empregadores;

- A carreira representa validação e empregabilidade independente da organização empregadora atual do indivíduo;

- A carreira é sustentada por redes ou informações extra organizacionais;

- Os limites da carreira organizacionais são quebrados, tais como, estruturas hierarquizadas e princípios de avanço na carreira;

- Pessoas rejeitam oportunidades de carreira por motivos pessoais ou familiares;

- $\mathrm{O}$ ator de carreira pode perceber um futuro sem fronteiras independente de restrições estruturais. 
A concepção de carreiras sem fronteiras não caracteriza nenhuma forma singular de carreira, mas abrange possíveis formas que desafiam as concepções tradicionais de trabalho. Nesse sentido, Michael Arthur sistematizou textos que tratavam das novas tendências do trabalho que se refletem na postura do trabalhador e das organizações (VELOSO, 2009).

Com a carreira sem fronteiras, o contrato psicológico ganha força e os "benefícios sem fronteiras" assumem um papel mais importante. Os "benefícios sem fronteiras" são aqueles que prevalecem além do tempo de trabalho, como aprendizado e desenvolvimento (ARTHUR et al, 1999).

A carreira sem fronteiras pode fazer mais sentido para empregadores e empregados que tentam se adaptar a nova economia (ARTHUR, 1994).

O ator de carreira é modelado pelas forças econômicas e também modela essas forças, logo ele é produto e produtor do ambiente de trabalho em que participa, revertendo a lógica da carreira tradicional que via o ator de carreira como passivo perante as mudanças ambientais (ARTHUR, 1994; ARTHUR et al, 1999).

A carreira sem fronteiras busca olhar também o lado subjetivo da carreira, além do lado objetivo, balanceando esses dois elementos (ARTHUR et al, 1999). Enfatiza as inúmeras possibilidades que a carreira apresenta, ou seja, ela não é relacionada a uma única organização e não é representada em uma sequência ordenada, vertical. A carreira sem fronteiras é apoiada por redes de fora da organização, reconhece que relações familiares e pessoais têm um impacto significativo e que a carreira deve ser interpretada de forma subjetiva pelo próprio ator (BRISCOE; HALL, 2006; ARTHUR, 1994).

Atuando em "negócios inteligentes" (“intelligente enterprises”) os indivíduos desenvolvem "carreiras inteligentes" ("intelligent careers") que buscam o desenvolvimento de três competências (ARTHUR et al, 1995):

- Knowing-why ou saber por que: natureza e extensão da identificação do empregado com a cultura e objetivos da organização empregadora.

- Knowing-how ou o saber como: capacidades e conhecimentos que o empregado traz para o know-how geral da organização. 
- Knowing-who ou o saber quem: um conjunto de relacionamentos interpessoais com o qual um empregado contribui para a rede de relacionamentos da organização.

Essas competências individuais são fundamentais para a construção das competências essenciais das organizações empregadoras e contribuem para que elas se tornem negócios inteligentes.

Sullivan e Arthur (2006) descrevem a carreira sem fronteiras em duas dimensões principais: a mobilidade física e a mobilidade psicológica. $\mathrm{O}$ ator de carreira pode manifestar um maior grau de mobilidade física quando se move entre empregadores e um maior grau de mobilidade psicológica quando demonstra uma atitude de iniciar ou procurar relacionamentos profissionais além das fronteiras de um único empregador. Os autores destacam essas duas dimensões enfatizando que a carreira sem fronteiras não é apenas baseada na mobilidade física e que o fato de um indivíduo permanecer em uma única organização não quer dizer que ele não possua uma mentalidade sem fronteiras.

Os autores defendem que ter uma carreira sem fronteiras não se trata de possuir um ou outro tipo de mobilidade e sim das diferentes combinações desses dois tipos de mobilidade. Essas duas dimensões devem ser analisadas em um continuum. Para explicar esse conceito, eles apresentam a Ilustração 3 que representa essas diferentes combinações em 4 quadrantes. A carreira sem fronteiras pode ser vista e operacionalizada pelo grau de mobilidade exibida pelo ator de carreira ao longo do continuum de mobilidade física e ao longo do continuum de mobilidade psicológica. 


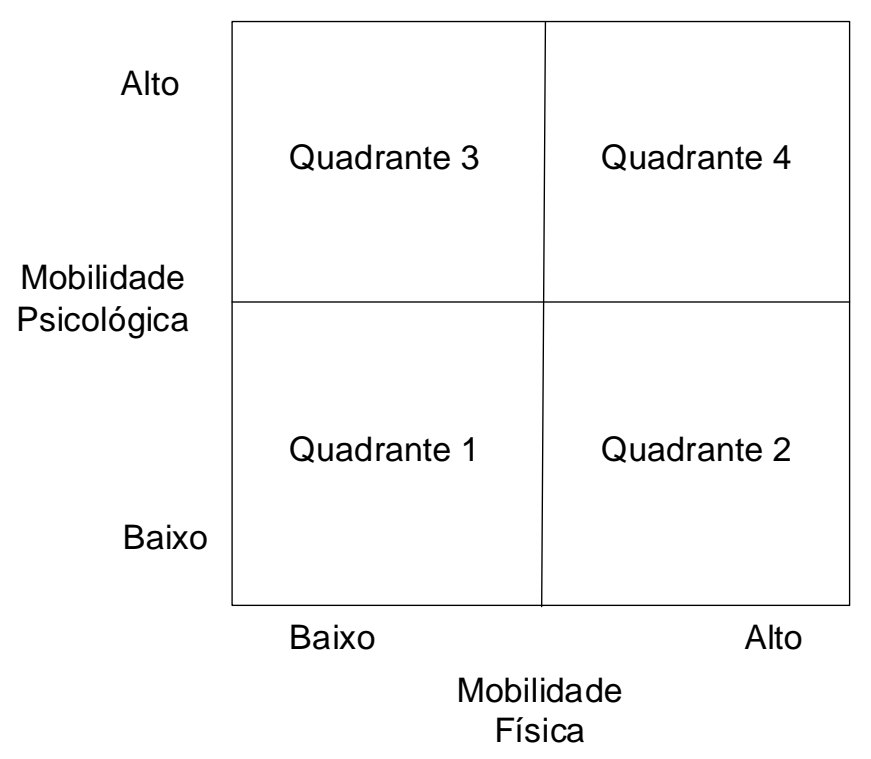

Ilustração 3 - Duas dimensões da carreira sem fronteiras Fonte: SULLIVAN; ARTHUR, 2006, p. 22 (tradução da autora)

Os quatro quadrantes são definidos por Sullivan e Arthur (2006) da seguinte forma:

- Quadrante 1: baixa mobilidade física e psicológica. Composto por pessoas que têm conhecimentos muito específicos que se aplicam a determinado contexto de organização e indústria, por pessoas que buscam estabilidade profissional, por pessoas que não possuem qualificação para ocupar outras posições ou pelos desempregados.

- Quadrante 2: alta mobilidade física e baixa mobilidade psicológica. Composto por pessoas que estão dispostas a mudanças físicas de local de trabalho ou organização por motivos pessoais, mas que buscam continuidade e similaridade entre essas diferentes ocupações.

- Quadrante 3: baixa mobilidade física e alta mobilidade psicológica. Composto por pessoas que têm altas expectativas de empregabilidade sem necessitar se mover fisicamente.

- Quadrante 4: alta mobilidade física e psicológica. Composto por pessoas que apresentam muitas mudanças físicas enquanto mudam sua orientação psicológica de carreira frequentemente, tais como, indivíduos que mudam de emprego e buscam novas oportunidades de aprendizado e desafios ou buscam atender necessidades pessoais ou familiares. 
Existem diversos tipos de mobilidade. Ela pode ocorrer cruzando fronteiras dentro da organização e ser departamental, divisional, hierárquica ou geográfica, e pode ocorrer cruzando fronteiras entre organizações, entre profissões, indústrias e vida profissional e familiar (SULLIVAN; ARTHUR, 2006).

Briscoe e Finkelstein (2009) concluíram que existe uma correlação negativa entre mobilidade física e diversas bases de comprometimento organizacional, no entanto, não encontraram evidências de relação entre comprometimento afetivo e a carreira sem fronteiras. Os pesquisadores também observaram que menores oportunidades de desenvolvimento resultaram em menor comprometimento para aqueles indivíduos com altos níveis de mobilidade psicológica. A violação no contrato psicológico de trabalho pode influenciar negativamente de forma mais consistente o comprometimento organizacional dos indivíduos cuja carreira seja do tipo sem fronteiras.

\subsubsection{Carreira proteana}

O conceito de carreira proteana também surge como uma resposta para explicar a carreira perante as inúmeras transformações que as organizações e o ambiente em que estão inseridas enfrentaram nos últimos anos. Perante um mundo baseado em velocidade e complexidade, o contrato de trabalho passa a ter uma visão de mais curto prazo, sendo renovado diariamente, apoiado em necessidades atuais e desempenho. A carreira proteana é caracterizada pela mudança frequente e autoinvenção, autonomia e autogestão - direcionadas pelas necessidades do indivíduo ao invés da necessidade da organização. Daí surge o termo proteana, que provém do nome do deus grego Proteus que muda sua forma de acordo com sua vontade (HALL, 2002). A palavra "proteana" é sinônimo de flexibilidade com uma conotação especial de mudar de forma. O poder do conceito de carreira proteana está relacionado em parte com sua ressonância com as questões modernas de trabalho flexível e contingente (INKSON, 2006).

A carreira proteana é gerenciada pelo ator de carreira, e não pela organização, de acordo com suas próprias necessidades, valores e busca de seu sucesso psicológico, ao invés de uma definição externa de sucesso. A organização oferece menos segurança, mas há mais liberdade e oportunidade de criar segurança através de habilidades e capacidade de aprender. 
Para que o ator de carreira proteana tenha sucesso em sua carreira é necessário que ele seja altamente flexível e adaptativo. Todavia a adaptabilidade deve ser guiada por um forte e claro senso de identidade. A identidade e a autoconsciência funcionam como uma bússola interna para as decisões de carreira (HALL, 2002).

Hall (2002) aponta dois elementos principais da carreira proteana: o autoconhecimento e a adaptabilidade. Ele considera esses elementos metacompetências, porque são capacidades necessárias para aprender a aprender.

Dentro da abordagem da carreira proteana, o empregador tem o papel de prover oportunidades, flexibilidade e recursos para possibilitar que o empregado desenvolva essas metacompetências e esteja no comando da própria carreira. Essa é uma importante moeda de troca na relação entre empregado e empregador, ou seja, o empregador oferece oportunidades de desenvolvimento e ganhos de curto prazo para o empregado que, por sua vez, oferece desempenho e esforço adicional, dentro do contrato psicológico desenvolvido entre as partes (HALL, 2002).

O contrato da carreira proteana é definido por Hall (2002) da seguinte forma:

- A carreira é gerenciada pela pessoa, não pela organização;

- A carreira é uma série de experiências, habilidades, aprendizados, transições e mudanças de identidade ao longo da vida;

- Desenvolvimento é aprendizado contínuo, autodirecionado, relacional e é promovido em desafios de trabalho;

- Desenvolvimento não é necessariamente treinamento formal ou mobilidade vertical;

- Os ingredientes do sucesso mudaram: de saber fazer para saber aprender; de estabilidade para empregabilidade, de carreira organizacional para carreira proteana, de vida no trabalho para vida integral;

- A organização provê: tarefas desafiadoras, relacionamentos que trazem desenvolvimento, informação e outros recursos para desenvolvimento;

- O objetivo é sucesso psicológico. 
O contrato de trabalho na carreira proteana aborda um forte sentido pessoal, observando também o equilíbrio entre vida pessoal e trabalho. A busca da satisfação é relacionada ao trabalho realizado e não a empresa empregadora (HALL, 2002).

As grandes cidades, como São Paulo, favorecem o desenvolvimento de uma carreira proteana, por concentrarem elementos que facilitam o fortalecimento do indivíduo, tais como, educação, número de empregos, nível de investimento financeiro, serviços de saúde, etc. (RIBEIRO et al, 2009).

Briscoe e Finkelstein (2009) não encontraram evidências de qualquer relação entre as dimensões da carreira proteana e comprometimento organizacional, ou seja, apesar de terem uma carreira autogerenciada e focada em suas necessidades e interesses pessoais, os atores de carreira proteana não necessariamente apresentam menor comprometimento com suas organizações empregadoras.

Briscoe e Hall (2006) definem duas dimensões principais da carreira proteana. A primeira é que o indivíduo tem um autodirecionamento na gestão de sua carreira, tendo a habilidade de se adaptar em termos de demandas de desempenho e aprendizado. A segunda é que as pessoas são direcionadas por seus valores pessoais, no sentido em que os valores pessoais provêm direcionamento e mensuram o sucesso na carreira, ao invés de motivadores extrínsecos como cargos, salário, etc.

Uma pesquisa qualitativa conduzida na Austrália por Sargent e Domberger (2007) explorou o desenvolvimento da carreira proteana, principalmente o desenvolvimento da orientação pelos valores entre jovens no início da carreira. Foram identificados dois valores principais que norteiam as decisões profissionais dos jovens entrevistados: contribuição social através do trabalho e equilíbrio entre vida profissional e pessoal.

A carreira proteana inicia seu desenvolvimento, quando o indivíduo observa e se identifica com seus familiares, pares e colegas, utilizando-os como modelos a partir dos quais ele pode imaginar seu eu ideal ou possível. Após isso, com a experiência prática de trabalho, o indivíduo testa funções e trajetórias de carreira e os compara com seus valores emergentes. Nessa vivência, os valores podem ser confirmados ou rejeitados a partir da preferência pessoal do ator de carreira. Durante a trajetória profissional, existem momentos críticos, tais 
como, mudanças no status do trabalho ou a falta de uma promoção esperada, que geram dilema e reflexão para o ator de carreira proteana. Diante dessa situação, ele questiona seus valores, objetivos e planos de carreira, avaliando a compatibilidade entre eles. Nesses momentos, objetivos e planos incompatíveis com os valores são rejeitados e alternativas melhores são elaboradas (SARGENT; DOMBERGER, 2007).

\subsubsection{Críticas às novas carreiras}

A literatura atual sobre carreiras tem se dedicado ao estudo das novas carreiras e seus desdobramentos para indivíduos e organizações, no entanto, existem críticas quanto à operacionalização desses conceitos, principalmente o conceito de carreira sem fronteiras que é descrito como "confuso" por Rodrigues e Guest (2010, p. 1157).

Esses autores buscaram confirmar se as carreiras atualmente são sem fronteiras com base nas principais evidências apresentadas pelos autores seminais no assunto: o aumento da rotatividade e a redução do tempo de empresa dos empregados. Analisando dados dos Estados Unidos e de diversos países da Europa concluíram que as estatísticas não corroboram essa premissa, já que não houve alterações significativas nessas duas variáveis desde 1992.

Diversos limites de carreira são conhecidos na literatura, tais como, profissão, localização geográfica do trabalho, natureza do contrato de trabalho e família. Apesar disso, a academia os examina isoladamente ao invés de serem analisados de forma sistemática e integrada (RODRIGUES; GUEST, 2010). Estudos apontam que a possibilidade de cruzamento de um tipo de fronteira, por exemplo, organizacional, inibe o cruzamento de outras fronteiras, por exemplo, profissão ou indústria (INKSON, 2006).

Além disso, Rodrigues e Guest (2010) apontam que a autogestão de carreira ainda não é uma realidade para grande parte dos trabalhadores que esperam suporte e direcionamento das organizações em que trabalham. Mobilidade pode ser resultado não de uma orientação proativa e de autovalidação de carreira, mas de incapacidade ou marginalização (INKSON, 2006).

Considerando que nem todos percebem suas carreiras com as características das carreiras modernas, Rodrigues e Guest (2010) apontam que essas podem ser modelos interessantes para 
determinados tipos de ocupação e mercado, como por exemplo, os empregados de Tecnologia da Informação do Vale do Silício norte-americano.

Sommerlund e Boutaiba (2007) concluem que uma distinção rígida entre carreiras antigas e novas é problemática porque, as duas carreiras, tanto a antiga quanto a nova, ainda estão presentes e elas são pré-requisitos uma da outra e não contrastantes.

Uma perspectiva crítica no debate atual sobre carreiras é visto como raro por Sommerlund e Boutaiba (2007), pois o ideal de liberdade é uma noção tão saturada de valor positivo que parece contraintuitivo contestar. No entanto, existem boas razões para interpretar o tom ideológico de liberdade com suspeita, principalmente quando ele age sobre o indivíduo como um regime institucionalizado e de incessante autorreflexão, exigindo esforço permanente de invenção e reconstrução de si. Nesse contexto, a liberdade é vista por esses autores como um panóptico sofisticado, estendido no tempo, ao invés do espaço, que desempenha um controle interno sutil e eficiente.

Sullivan e Arthur (2006) expressam a necessidade do estudo da mobilidade psicológica, já que muitos pesquisadores analisam as carreiras sem fronteiras pela perspectiva da mobilidade física exclusivamente, já que ela é mais facilmente mensurada contando-se o número de vezes que uma pessoa mudou de trabalho, empregadores ou profissões.

Inkson (2006) analisa as carreiras proteana e sem fronteiras como metáforas. A visão desses constructos como metáforas pode reforçar seus significados e estimular o desenvolvimento criativo. Por outro lado, pode ser restritiva no sentido de criar estereótipos, simplificar ou distorcer realidades. $\mathrm{O}$ autor defende as carreiras sem fronteiras como "carreiras de cruzamento de fronteiras ${ }^{2}$, , pois ao cruzarmos fronteiras elas são transcendidas, mas não removidas.

A busca dos termos carreira proteana e carreira sem fronteiras em bases de dados acadêmicas e livros sobre comportamento organizacional, gestão de recursos humanos e gestão de carreiras sugere que o conceito de carreira sem fronteiras tem sido mais utilizado do que o de carreira proteana. Inkson (2006) atribui esse resultado a estratégia de Arthur e Rousseau

\footnotetext{
${ }^{2}$ Boundary-crossing career
} 
(1996) de incluir o nome da metáfora como título de um livro importante, mostrando a eficácia do conceito dentro da nova economia e convidando comentadores de disciplinas não relacionadas à carreira, como Karl Weick e Charles Perrow, para relacionar as carreiras sem fronteiras com fenômenos organizacionais e sociais mais amplos.

O movimento de desenvolvimento de carreira foca principalmente as dinâmicas psicológicas da escolha e processo decisório na carreira e ignora questões de organizações e mercado de trabalho. Estudos empíricos sobre as dinâmicas das novas formas de carreira são extremamente necessários (INKSON, 2006).

No Brasil, a dinâmica foi inversa. Nos anos 80, uma atenção especial foi dada ao estudo das carreiras nas organizações e no mercado de trabalho. Somente no final da década de 80 e início da de 90 é que os trabalhos de pesquisa se voltaram para a pessoa (DUTRA, 2010).

Observa-se no Brasil uma grande resistência ao planejamento individual de carreira. As pessoas tendem a guiar suas carreiras mais por apelos externos, tais como, remuneração, prestígio e etc., do que por preferências pessoais. Além disso, as pessoas encaram suas carreiras como identificação de oportunidades na organização onde atuam ou no mercado de trabalho. Essa postura conduz a um movimento motivado pelo externo, em que as possibilidades oferecidas influenciam as escolhas. Essa forma de pensar a carreira leva as pessoas a cometer alguns equívocos importantes, tais como: a visão restrita de oportunidades, armadilhas profissionais e a subutilização da capacidade profissional (DUTRA, 2010).

\subsubsection{Perfis de carreira}

Os constructos de carreira proteana e sem fronteiras têm amparado as pesquisas recentes sobre carreiras, mas existia uma lacuna em relação a uma avaliação empírica destes fenômenos. Buscando corrigir essa situação, Briscoe et al (2006) propõem uma forma empírica de analisar os modelos de carreira proteana e sem fronteiras. Os autores desenvolveram e validaram um modelo com quatro escalas para medir atitudes de carreira proteana e sem fronteiras.

As escalas referentes ao modelo de carreira sem fronteiras medem: 
- Mobilidade psicológica: a mentalidade sem fronteiras, ou seja, a atitude geral do indivíduo de trabalhar além das fronteiras organizacionais, demonstrando interesse em interagir com pessoas de fora da organização, em ter novas experiências e aprendizado constante;

- Mobilidade física: a preferência de mobilidade organizacional, ou seja, o nível de interesse em se mover entre diferentes empregadores.

As escalas referentes ao modelo de carreira proteana medem:

- Autodirecionamento: a gestão da carreira direcionada pelo indivíduo que cria suas próprias oportunidades de desenvolvimento. Está relacionado à adaptabilidade e a responsabilidade pela própria carreira

- Orientação pelos valores pessoais: o indivíduo prioriza seus valores pessoais ao estabelecer prioridades, objetivos e tomar suas decisões de carreira. Os valores também são a medida de sucesso na carreira.

Apesar de ambos os constructos, tanto o da carreira proteana, quanto o da carreira sem fronteiras, terem surgido como uma resposta para observar a carreira dentro da nova realidade econômica, social e organizacional, é possível observar diferenças entre essas abordagens. De acordo com os estudos conduzidos por Briscoe et al (2006) utilizando a escala descrita acima, os dois constructos são relacionados, mas são diferentes entre si. Outro achado importante dessa pesquisa se refere à questão da mobilidade: a mobilidade não pode ser julgada como necessária para uma atitude de carreira proteana ou sem fronteiras, ou seja, é possível possuir atitudes de carreira proteana ou sem fronteiras permanecendo em um único empregador.

De Bruin e Buchner (2010) realizaram uma nova validação das escalas de atitude proteana e sem fronteiras em indivíduos da África do Sul. Esse estudo foi motivado pela identificação por parte dos autores sul-africanos de problemas no artigo original de Briscoe et al (2006). As principais críticas dizem respeito a baixas cargas fatoriais e escores em indicadores de confiabilidade, técnicas utilizadas e o modo de testar os fatores, já que cada escala foi testada separadamente. Outro objetivo da pesquisa foi a avaliação da validade do instrumento fora dos Estados Unidos. 
Diante desse novo teste, os autores identificaram que o fator Orientação pelos Valores poderia ser dividido em dois e que as questões 1, 8, 15, 21 e 23 apresentaram resultados insatisfatórios nas análises fatoriais, sugerindo que elas sejam alteradas e novamente testadas em estudos futuros. Os autores apontam limitações no estudo, já que apenas uma amostra foi analisada, e sugerem que os resultados encontrados devem ser comparados com os de outras amostras e em outros contextos culturais.

No Brasil, Silva (2009) realizou a validação semântica da escala proposta por Briscoe et al (2006). Além disso, o pesquisador também concluiu a validação estatística com resultados satisfatórios dos testes de confiabilidade e consistência interna utilizando o coeficiente alfa de Cronbach, análise do coeficiente meio a meio de Spearman-Brown e a avaliação do efeito piso e teto. Para a validação semântica, o pesquisador utilizou a técnica de back-translation e um pré-teste foi realizado com um grupo de 15 pessoas. Após isso, o instrumento foi aplicado junto a 516 estudantes de graduação em Administração da Universidade de Uberaba, em Minas Gerais, onde 426 tiveram seus escores validados após análise de dados perdidos. Os resultados indicaram presença moderada de atitudes inerentes aos dois modelos, bem como apontou uma significante relação direta entre a carreira proteana e carreira sem fronteiras.

O pesquisador encontrou uma pequena relação positiva entre mobilidade psicológica e idade e tempo de empresa e uma fraca correlação positiva entre mobilidade psicológica e o fato do respondente estar empregado. A mobilidade física apresentou fraca relação inversa com a idade e com o tempo de empresa (SILVA, 2009).

Em uma tentativa de tornar esses conceitos mais acessíveis para indivíduos e organizações, Briscoe e Hall (2006) propuseram categorias de novas carreiras que utilizam combinações entre as carreiras proteanas e sem fronteiras. Essas categorias ou perfis de carreira facilitam a identificação por parte dos indivíduos de suas próprias identidades e oportunidades de carreira, buscando oferecer, de forma simples e clara, opções mais amplas para identificação do que simplesmente os constructos de carreira proteana e sem fronteiras.

Briscoe e Hall (2006) sugeriram oito perfis de carreira baseados na combinação dos níveis de presença das atitudes de carreira proteana e nos níveis de presença das atitudes da carreira sem fronteiras utilizadas na pesquisa de Briscoe et al (2006). Observando-se as possibilidades da combinação das quatro dimensões, calculam-se dezesseis perfis de carreira, mas apenas 
oito foram apontados, baseados na possibilidade de gerar exemplos reais que se adequassem a dada combinação, considerando a experiência prática dos autores. Os oito perfis de carreira apontados estão descritos no quadro 1:

Quadro 1 - Perfis de carreira

\begin{tabular}{|c|c|c|c|c|c|}
\hline $\begin{array}{l}\text { Perfis de } \\
\text { carreira }\end{array}$ & $\begin{array}{l}\text { Proteana: } \\
\text { auto- } \\
\text { direciona- } \\
\text { mento }\end{array}$ & $\begin{array}{l}\text { Proteana: } \\
\text { orientação } \\
\text { pelos } \\
\text { valores }\end{array}$ & $\begin{array}{l}\text { Sem } \\
\text { fronteiras: } \\
\text { mobilidade } \\
\text { psicológica }\end{array}$ & $\begin{array}{l}\text { Sem } \\
\text { fronteiras: } \\
\text { mobilidade } \\
\text { física }\end{array}$ & $\begin{array}{l}\text { Desafios pessoais do ator para } \\
\text { manutenção do status-quo }\end{array}$ \\
\hline $\begin{array}{l}\text { "Perdido" ou } \\
\text { "Preso" }\end{array}$ & Baixo & Baixo & Baixo & Baixo & $\begin{array}{l}\text { Reage rapidamente as oportunidades, } \\
\text { sobrevive }\end{array}$ \\
\hline "Seguro" & Baixo & Alto & Baixo & Baixo & $\begin{array}{l}\text { Procura estabilidade, oportunidades } \\
\text { em organizações previsíveis e } \\
\text { alinhada aos valores individuais }\end{array}$ \\
\hline "Andarilho" & Baixo & Baixo & Baixo & Alto & $\begin{array}{l}\text { Procura continuamente novos } \\
\text { caminhos para trilhar }\end{array}$ \\
\hline "Idealista" & Baixo & Alto & Alto & Baixo & $\begin{array}{l}\text { Procura organizações alinhadas aos } \\
\text { valores individuais e curiosidade, } \\
\text { mas não demanda mobilidade }\end{array}$ \\
\hline $\begin{array}{l}\text { "Organiza- } \\
\text { cional" }\end{array}$ & Alto & Baixo & Alto & Baixo & $\begin{array}{l}\text { Procura organizações estáveis em que } \\
\text { competências de desempenho básico } \\
\text { possam ser demonstradas }\end{array}$ \\
\hline $\begin{array}{l}\text { “Cidadão } \\
\text { sólido" }\end{array}$ & Alto & Alto & Alto & Baixo & $\begin{array}{l}\text { Alinhamento entre pessoa e } \\
\text { organização é fundamental. } \\
\text { Mobilidade é uma ameaça. }\end{array}$ \\
\hline $\begin{array}{c}\text { "Contrata- } \\
\text { do" }\end{array}$ & Alto & Baixo & Alto & Alto & $\begin{array}{l}\text { Identifica e responde as melhores } \\
\text { oportunidades para prover serviços } \\
\text { através das fronteiras. }\end{array}$ \\
\hline $\begin{array}{l}\text { "Arquiteto } \\
\text { da carreira } \\
\text { proteana" }\end{array}$ & Alto & Alto & Alto & Alto & $\begin{array}{l}\text { Alavanca capacidade para um } \\
\text { impacto significativo }\end{array}$ \\
\hline
\end{tabular}

Fonte: adaptado de BRISCOE; HALL, 2006, p. 8 (tradução da autora)

Briscoe e Hall (2006) descreveram as características de cada perfil de carreira conforme exposto abaixo, destacando os desafios de ator de determinado perfil e oferecendo sugestões para o seu desenvolvimento:

- "Perdido" ou "Preso": as pessoas desse perfil são consideradas "perdidas" ou "presas" no sentido da falta de ênfase em seus valores pessoais, que poderiam direcioná-las, e na fala de ênfase em perspectivas sem fronteiras, que poderiam lhes prover mais opções. Logo, elas estão restritas às poucas possibilidades dentro das quais elas têm pouco controle. São as pessoas que mais precisam se adaptar a economia moderna. Dessa forma o desafio está em reagir rapidamente para sobreviver, buscando mais a sorte do que qualquer coisa em seu controle. Essas pessoas podem ser ajudadas com processos básicos de desenvolvimento de carreira, tais como, clareza dos valores e aumento da autoeficácia 
relacionada à carreira. Atividades exploratórias de carreira podem ajudar a motivá-los a buscar novas oportunidades baseadas em seus valores e interesses. É interessante a exposição a pessoas e grupos de fora de suas organizações e indústrias que lhes deem a oportunidade de serem mais sem fronteiras no pensamento e na ação. Esses indivíduos deveriam ser responsabilizados por seus comportamentos de forma a encorajar e reforçar autonomia. A abertura para novas experiências é fundamental para o desenvolvimento de novas atitudes de carreira nesses indivíduos.

- "Seguro": esse ator de carreira tem valores pessoais claros, mas é inflexível em sua habilidade de direcionar seus próprios comportamentos de carreira e reconhecer oportunidades além das fronteiras psicológicas e físicas. Buscam situações estáveis onde seus valores sejam respeitados, geralmente em funções, organizações ou oportunidades que possam oferecer isso. O fluxo da nova economia faz com que seja difícil encontrar essas pessoas, já que as organizações e condições mudam e a continuidade em uma situação de alinhamento com os valores pode não ser sustentável por muito tempo. Para desenvolver esse tipo de ator de carreira deve-se estimular a consciência e exploração de oportunidades além das fronteiras e a independência para buscar novas oportunidades.

- "Andarilho": a limitação desse ator de carreira é que sua mobilidade psicológica não é tão sofisticada quanto sua mobilidade física. Sua falta de autodirecionamento e orientação pelos valores faz com que eles sejam controlados pelas oportunidades ao invés de controlá-las. A busca é por novas oportunidades para manutenção do status-quo. O aprendizado está em buscar clareza em relação aos valores pessoais e procurar maior proatividade no comando da carreira.

- "Idealista": são pessoas orientadas por seus valores e que apresentam mentalidade sem fronteiras, mas não necessariamente fazem uma gestão efetiva de suas carreiras ou apresentam mobilidade física. Esses indivíduos buscam oportunidades que permitam a manutenção de seu idealismo sem a necessidade de flexibilidade e movimentação. $O$ desafio é retirá-los da zona de conforto e encorajá-los a gerenciar suas próprias carreiras. Isso pode ser desenvolvido através a imersão em oportunidades de mobilidade física como intercâmbios, expatriações, licenças, participação em grupos externos e também através da participação em programas de mentoring. 
- "Organizacional”: são pessoas com fortes habilidades de direcionar suas carreiras, mas que não têm muita clareza de seus valores pessoais. São hábeis em trabalhar além de fronteiras psicológicas, mas não das fronteiras físicas. Essas pessoas adaptam sua carreira de acordo com a necessidade de terceiros, geralmente das organizações, ao invés de suas próprias necessidades ou seus valores pessoais. Indivíduos desse perfil tem um risco de não alcançar seu máximo potencial advindo do alinhamento do trabalho executado com seus valores pessoais. Experiências que forçam as pessoas para fora de sua zona de conforto podem causar grande introspecção e reflexão sobre os valores. Uma abordagem é a maior exposição à mobilidade física, buscando novas perspectivas e experiências.

- "Cidadão Sólido": apresentam autodirecionamento da carreira, são orientados pelos valores pessoais, apresentam mobilidade psicológica, mas não demonstram mobilidade física, seja por uma questão de preferência ou de circunstância. Essas pessoas idealmente precisam buscar um lugar para desenvolver suas carreiras que combine com seus fortes valores pessoais, permitindo autonomia, aprendizado e a satisfação de sua curiosidade no trabalho. Organizações, parceiros e outros que se relacionam com o "cidadão sólido" precisam reconhecer suas limitações em termos de mobilidade física, mas também alavancar sua valiosa contribuição. Além disso, é importante manter a diversidade de tipos de colaboradores no sentido de ter pessoas que demonstrem alta mobilidade física, de acordo com necessidades do negócio e da organização.

- "Contratado": são pessoas que gerenciam suas carreiras, que tem interesse em trabalhar além das fronteiras física e psicológica, mas não são orientadas por seus valores pessoais, ou seja, não tem um forte senso de prioridade para sua carreira. Eles não são muito bons em definir e responder a seus valores pessoais e buscam identificar as melhores oportunidades para obter retorno sobre suas habilidades. O ponto de desenvolvimento é buscar desenvolver a dimensão de valores nessas pessoas, estimulando-os a serem líderes de si mesmos ou líderes de equipes. Sem a dimensão de valores, o "contratado" pode se tornar uma ferramenta de trabalho, mas não ser capaz de dirigir a mudança.

- “Arquiteto da Carreira Proteana”: é o indivíduo psicologicamente e fisicamente sem fronteiras, que ativamente gerencia sua própria carreira e é orientado por seus valores pessoais em sua jornada para definir sentido e sucesso ao longo da carreira. Ele combina 
todo o potencial das perspectivas de carreira proteana e sem fronteiras. $\mathrm{O}$ desafio desse ator pode ser em decidir onde aplicar sua habilidade e em identificar trabalhos que gerem resultados alinhados a seus valores. Questões de equilíbrio podem se tornar um desafio para o "arquiteto da carreira proteana". Os desafios para as organizações em gerir esses indivíduos são os de fazer uma gestão sem fronteiras, adaptando suas políticas e práticas a essa nova mentalidade.

A identificação de perfis de carreira permite a exploração de desafios pessoais que um determinado ator de carreira pode enfrentar para a manutenção de seu status-quo. Também direciona os desafios e oportunidades de desenvolvimento que se apresentam para aqueles que querem fortalecer seus perfis de carreira, assim como para organizações, grupos de suporte, conselheiros de carreira, mentores e outros interessados em ajudar as pessoas em seu desenvolvimento de carreira. Entender os pontos fortes de um determinado perfil de carreira permite um desenvolvimento mais cuidadoso de combinações poderosas de competências de carreira (BRISCOE; HALL, 2006).

Segers et al (2008) adaptaram os itens de um questionário de motivação para as quatro dimensões de carreira propostas por Briscoe et al (2006). Foram utilizados nesse estudo as respostas de 13.000 indivíduos residentes na Europa para análise da relação entre as dimensões de carreira desses indivíduos e suas características demográficas e também para o desenvolvimento de clusters que foram posteriormente comparados com os descritos por Briscoe e Hall (2006).

Os resultados das análises de regressão confirmaram a maioria das hipóteses sobre a influência do gênero, idade, educação e experiência gerencial dos respondentes em suas atitudes de carreira. Os principais achados dessas relações analisadas foram:

- Gênero: mulheres apresentaram maior mobilidade psicológica e homens apresentaram maior mobilidade física, conforme proposto por Sullivan e Arthur (2006). Esses achados são justificados com base nas descontinuidades de carreira que acontecem com as mulheres decorrentes do nascimento de filhos e das expectativas sociais quanto ao papel do homem no sustento da casa e da família. 
- Idade: os mais jovens apresentam maior mobilidade psicológica pelo interesse em se relacionar com várias pessoas e apresentam menor orientação a valores. Pessoas entrando na força de trabalho passam por uma fase de tentativa e erro tentando descobrir como e onde elas podem gerenciar suas carreiras. $\mathrm{O}$ desejo de se mover fisicamente reduz-se com o aumento da idade.

- Educação: indivíduos com maior escolaridade apresentam maior autodirecionamento, mobilidade física e psicológica e menor orientação a valores.

- Experiência profissional em posições de gestão: indivíduos com maior experiência profissional apresentam maior autodirecionamento, mobilidade física e psicológica.

Além disso, foram identificados quatro clusters, sendo que três deles foram descritos por Briscoe e Hall (2006): "Perdido", "Contratado" e "Arquiteto da Carreira Proteana". Um quarto clusters não descrito anteriormente foi encontrado apresentando baixos resultados nas dimensões de carreira proteana e altos resultados nas dimensões de carreira sem fronteiras. Esse último cluster foi classificado como "Curioso" ou "Andarilho", já que o perfil é similar ao do "Andarilho", mas compartilha a curiosidade do perfil "Idealista".

Os autores também identificaram o perfil demográfico predominante nos quatro clusters encontrados, conforme descrito no Quadro 2.

Quadro 2 - Relação entre características demográficas e perfis de carreira

\begin{tabular}{|l|l|l|l|l|}
\hline \multicolumn{1}{|c|}{$\begin{array}{c}\text { Perfil de } \\
\text { Carreira }\end{array}$} & \multicolumn{1}{|c|}{ Gênero } & \multicolumn{1}{|c|}{ Idade } & Educação & Experiência profissional \\
\hline $\begin{array}{l}\text { Perdido ou } \\
\text { Preso }\end{array}$ & $\begin{array}{l}\text { Predominantemente } \\
\text { masculino }\end{array}$ & $\begin{array}{l}\text { Mais de 30 anos, } \\
\text { sendo a maioria com } \\
\text { idade entre 40 e 50 } \\
\text { anos }\end{array}$ & $\begin{array}{l}\text { Até Ensino } \\
\text { Médio }\end{array}$ & $\begin{array}{l}\text { Mais de } 10 \text { anos de } \\
\text { experiência profissional }\end{array}$ \\
\hline Curioso & $\begin{array}{l}\text { Predominantemente } \\
\text { feminino }\end{array}$ & Menos de 30 anos & $\begin{array}{l}\text { Até Ensino } \\
\text { Médio }\end{array}$ & $\begin{array}{l}\text { De 0 a 5 anos de } \\
\text { experiência profissional }\end{array}$ \\
\hline $\begin{array}{l}\text { Contratado } \\
\text { da carreira } \\
\text { proteana }\end{array}$ & $\begin{array}{l}\text { Predominantemente } \\
\text { masculino }\end{array}$ & Menos de 40 anos & $\begin{array}{l}\text { Ensino } \\
\text { Superior ou } \\
\text { acima }\end{array}$ & $\begin{array}{l}\text { De 3 a 10 anos de } \\
\text { experiência profissional }\end{array}$ \\
\hline
\end{tabular}

Fonte: adaptado de SEGERS et al (2008) 
Apresentados todos os aspectos teóricos de Carreira relevantes para esse estudo, segue-se para o aprofundamento da base teórica ingressando no tema Geração.

\subsection{Geração}

\subsubsection{Conceito de geração}

Pesquisas em diversas áreas das ciências sociais apontam a importância das questões geracionais. Observando o debate sobre o desenvolvimento de uma cultura global dos jovens socializados e influenciados pelas mesmas mídias sociais, programas de televisão, filmes e músicas, surge a questão se os jovens que estão ingressando no mercado de trabalho diferem sistematicamente e globalmente das gerações de seus pais (BRISCOE et al, 2012).

O conceito de geração tem sido um tema relevante nas ciências humanas e sociais. Ele exerce uma função de identidade, na medida em que posiciona o indivíduo dentro de um tempo social e coloca a sua própria história em uma história mais ampla. Apesar de sua relevância, ele ainda não teve uma atualização de suas bases teóricas e metodológicas (FEIXA; LECCARDI, 2010; EDMUNDS; TURNER, 2005).

Observa-se um interesse crescente no tema devido a mudanças demográficas, econômicas e culturais, tais como, o envelhecimento da população, a pressão sobre a previdência e os sistemas de saúde nacionais e o maior risco de conflito geracional decorrente de escassez de recursos, de empregos e das mudanças das políticas atuais (EDMUNDS; TURNER, 2005).

Em termos sociológicos, o conceito de geração foi inicialmente delimitado por Auguste Comte no século XIX. O quadro 3 resume as definições dos autores seminais sobre o assunto.

\section{Quadro 3 - Definições de geração}

\begin{tabular}{|l|l|}
\hline \multicolumn{1}{|c|}{ Autor } & \multicolumn{1}{c|}{ Definição de Geração } \\
\hline $\begin{array}{l}\text { Auguste Comte } \\
(1798-1857)\end{array}$ & $\begin{array}{l}\text { Geração medida pelo tempo linear de 30 anos. O progresso é identificado com as novas } \\
\text { gerações. }\end{array}$ \\
\hline $\begin{array}{l}\text { Wilhelm Dilthey } \\
(1833-1911)\end{array}$ & $\begin{array}{l}\text { Gerações são definidas em termos de contemporaneidade e consistem em um conjunto de } \\
\text { pessoas sujeitas ao mesmo conjunto de experiências e influências históricas comuns em } \\
\text { seus anos de maleabilidade máxima. }\end{array}$ \\
\hline
\end{tabular}




\begin{tabular}{|l|l|}
\hline \multicolumn{1}{|c|}{ Autor } & \multicolumn{1}{c|}{ Definição de Geração } \\
\hline José Ortega Y \\
$\begin{array}{l}\text { Gasset (1883- } \\
1955)\end{array}$ & $\begin{array}{l}\text { As pessoas nascidas em um mesmo tempo partilham da mesma "sensibilidade vital" que } \\
\text { se opõe às gerações anteriores e mais recentes e que define sua "missão histórica". Cada } \\
\text { geração acontece em um intervalo de 15 anos. }\end{array}$ \\
\hline $\begin{array}{l}\text { Karl Mannheim } \\
(1893-1947)\end{array}$ & $\begin{array}{l}\text { A geração é parte do processo histórico que jovens da mesma idade-classe de fato } \\
\text { compartilham. A data de nascimento é potencial para isso, mas não define a geração. } \\
\text { Existem dois elementos centrais para a constituição de uma geração: presença de eventos }\end{array}$ \\
& $\begin{array}{l}\text { que quebram a continuidade histórica e a vivência desse momento por membros de um } \\
\text { grupo etário durante seu processo de socialização (adolescência e início da idade adulta), } \\
\text { predispondo-os a certos modos de pensar e experiências. }\end{array}$ \\
\hline
\end{tabular}

Fonte: adaptado de FEIXA; LECCARDI, 2010; MANNHEIM, 1993

É possível notar no quadro 3, diferenças entre os autores no que se refere à definição de um tempo preciso para posicionar diferentes gerações. Comte e Ortega y Gasset definem tempos lineares de 30 e 15 anos respectivamente. Já Dilthey e Mannheim têm uma visão qualitativa do assunto, observando a internalização do momento e fatos históricos vividos em conjunto na fase de socialização de um determinado grupo. Mannheim vai além de Dilthey na medida em que traz mais um elemento, a classe social.

Um elemento comum a maioria dos conceitos é a vivência de experiências e de um momento histórico em comum na fase de formação de identidade e de socialização.

Para a presente dissertação será utilizado o conceito de Mannheim (1993) conforme descrito no quadro 3, pois é indicado pela literatura como o conceito mais influente atualmente (FEIXA; LECCARDI, 2010; PARRY; URWIN, 2010, WELLER, 2010; DENCKER et al, 2007; EDMUNDS; TURNER, 2005).

O que caracteriza uma posição comum dos nascidos em um mesmo tempo cronológico é a potencialidade de presenciar os mesmos acontecimentos, de vivenciar experiências semelhantes, mas, sobretudo, de processar esses acontecimentos ou experiências de forma semelhante.

A globalização e os meios modernos de comunicação, principalmente, a internet, ampliaram as possibilidades de participação de jovens de diferentes países em um conjunto de acontecimentos e experiências semelhantes colocando-os em uma mesma posição geracional (TAPSCOTT, 2010; EDMUNDS; TURNER, 2005). 
O conceito de geração de Mannheim rompe com a ideia de uma unidade de geração concreta e coesa e instiga a centrar as análises nas intenções observadas através de ações e expressões de determinados grupos, ao invés de buscar caracterizar suas especificidades. Perguntar-se pelos motivos das ações desses atores coletivos envolvidos em um processo de constituição de gerações, implica ainda em uma análise da conjuntura histórica, política e social a partir de uma perspectiva que pode se situar no nível macro, bem como do conhecimento adquirido pelos atores nos espaços sociais de experiências em conjunto, e que se pode denominar como sendo uma análise no campo micro (WELLER, 2010).

Dencker et al (2007) descrevem que as experiências comuns de pessoas de idades semelhantes atuam como lentes que proporcionam um determinado foco através das quais os eventos são interpretados. Segundo os autores, o foco da lente difere entre gerações provendo diferentes respostas em suas interações atuais.

Sociólogos modernos seguidores de Mannheim abriram o foco de eventos históricos para examinar elementos culturais como música, estrelas de cinema, moda, esporte, lazer, tecnologia e outros tipos de cultura popular (PARRY; URWIN, 2010).

Diversos autores utilizam o termo coorte como equivalente ao termo Geração. A diferença entre esses dois conceitos reside em seu ponto de origem e término. Para definição de uma coorte inicia-se pela determinação de uma faixa etária e depois se analisa a diferença entre essa faixa e as demais, encontrando diferenças em relação a valores, atitudes e comportamento entre indivíduos dos diversos grupos. A definição de uma geração inicia-se pela análise de eventos históricos, políticos ou sociais que geram um impacto em valores, atitudes e comportamentos das pessoas que viveram esses momentos em sua fase de socialização e posteriormente as datas de nascimento potenciais são definidas (PARRY; URWIN, 2010; DENCKER et al, 2007).

Nesse sentido destaca-se o estudo conduzido por Schuman e Scott (1989) nos Estados Unidos. Os pesquisadores pediram a uma amostra nacional representativa de indivíduos para relembrarem de eventos históricos críticos importantes para eles e então explicar o motivo da escolha desses eventos. Além disso, foram conduzidas entrevistas desenhadas para estimular reações dos respondentes a respeito de fatos históricos. Através desse estudo, concluiu-se que diferentes gerações se lembram de diferentes eventos e que seus anos formativos tem um 
papel chave nas memórias coletivas, conforme teoria de Mannheim, confirmando empiricamente sua definição de geração.

Diferenças regionais e atributos pessoais, tais como idade, educação, gênero e raça também têm um papel importante nas memórias coletivas, trazendo diferenças entre os grupos geracionais (DENCKER et al, 2008).

Efeitos de idade ou maturidade, ou seja, resultantes da faixa etária e amadurecimento do indivíduo, e efeitos do período, ou seja, os impactos do ambiente, devem ser considerados nos estudos de gerações. Existe uma dificuldade metodológica em separar o efeito da idade, os efeitos do período e os efeitos geracionais em uma análise (DENCKER et al, 2007). Para minimizar essa dificuldade, Parry e Urwin (2010) recomendam estudos longitudinais para determinação de efeitos geracionais.

Entretanto, a literatura sobre o assunto vai ao sentido inverso, apresentando diversas pesquisas quantitativas e qualitativas transversais para determinação de valores, expectativas e perfil das diferentes gerações. Como consequência, alguns estudos encontram diferenças entre gerações e outros não, além de divergirem quanto às datas de início e características das gerações (PARRY; URWIN, 2010).

\subsubsection{Gerações nas organizações}

Dencker et al (2008) fizeram uma profunda análise sociológica e psicológica para estabelecer a relação entre geração e o comportamento no trabalho. Os autores iniciaram sua construção com base na pesquisa sociológica de memórias coletivas. As memórias coletivas indicam que os eventos formadores tiveram impacto sobre os indivíduos de uma dada geração modelando seus valores e comportamentos e, consequentemente, suas expectativas sociais e em relação ao trabalho. Ao ingressar na organização, o indivíduo estabelece um contrato psicológico com o empregador baseado nessas expectativas. O cumprimento do contrato leva a emoções positivas que afetam positivamente o comprometimento, a satisfação e reduzem a intenção de sair da organização. $\mathrm{O}$ descumprimento ou rompimento do contrato afeta negativamente o comprometimento, a satisfação e aumenta a intenção do indivíduo em deixar a organização. 
Joshi et al (2010) após analisar diversos estudos sobre gerações nas organizações, identificaram três faces de identidade geracional utilizadas e que podem ser usadas como forma de categorização. Os autores propõe a utilização do conceito de geração de uma forma mais ampla, observando além da idade e considerando a importância de eventos históricos importantes ocorridos inclusive dentro da organização para a formação de gerações em micro ambientes. A primeira face é baseada em incumbência, ou seja, é relacionada à ocupação de um papel por um determinado período de tempo. A segunda é a baseada em coortes, que tem relação com a filiação do grupo de um mesmo tempo de empresa. A terceira face é baseada na idade, que tem relação com o conceito de geração de Mannheim e com indivíduos que compartilham idades semelhantes. O quadro 4 descreve essas faces:

Quadro 4 - Faces dos estudos sobre gerações nas organizações

\begin{tabular}{|l|l|l|l|}
\hline $\begin{array}{c}\text { Faces da } \\
\text { identidade } \\
\text { geracional }\end{array}$ & Referências teóricas & \multicolumn{1}{|c|}{ Definição } & \multicolumn{1}{c|}{$\begin{array}{c}\text { Processos relacionais entre } \\
\text { gerações }\end{array}$} \\
\hline $\begin{array}{l}\text { Baseada na } \\
\text { Incumbência }\end{array}$ & $\begin{array}{l}\text { Sociologia da família / } \\
\text { Antropologia social }\end{array}$ & $\begin{array}{l}\text { Baseado na ocupação de um } \\
\text { papel por um determinado } \\
\text { período de tempo }\end{array}$ & $\begin{array}{l}\text { Baseados em habilidades, } \\
\text { conhecimentos e decisões } \\
\text { diferentes, mas interdependentes, } \\
\text { associados a um cargo. }\end{array}$ \\
\hline $\begin{array}{l}\text { Baseada em } \\
\text { coortes }\end{array}$ & $\begin{array}{l}\text { Sociologia política / } \\
\text { Demografia } \\
\text { organizacional }\end{array}$ & $\begin{array}{l}\text { Baseado na filiação de um } \\
\text { grupo que compartilha } \\
\text { tempo de empresa } \\
\text { semelhante }\end{array}$ & $\begin{array}{l}\text { Baseados em diferentes formas } \\
\text { de emprego e experiências de } \\
\text { socialização organizacional }\end{array}$ \\
\hline $\begin{array}{l}\text { Baseada em } \\
\text { idade }\end{array}$ & $\begin{array}{l}\text { Sociologia / } \\
\text { Gerontologia }\end{array}$ & $\begin{array}{l}\text { Baseado na filiação de } \\
\text { grupo etário que divide } \\
\text { memórias coletivas em seus } \\
\text { anos formativos }\end{array}$ & $\begin{array}{l}\text { Baseados em diferentes } \\
\text { atitudes/valores a respeito do } \\
\text { trabalho e emprego }\end{array}$ \\
\hline
\end{tabular}

Fonte: JOSHI et al, 2010, p. 395 (tradução da autora)

Wade-Benzoni (2002) é um autor que utiliza a face da identidade geracional baseada na incumbência. Ele descreve que conjuntos de atores organizacionais do passado, presente e futuro podem ser pensados como diferentes gerações nas organizações. O enfoque do artigo é o conflito intergeracional, que ocorre quando uma geração de atores encara a decisão de assumir ou não os custos dos benefícios gerados às outras gerações. Isso é baseado na assimetria de poder, já que a geração mais antiga tem maior poder de decisão em detrimento das novas gerações.

O autor define que uma geração ocupa um papel que pode ser um escritório, status ou conjunto de responsabilidades e o tempo nesse papel é limitado no sentido de que uma geração não o ocupa indefinitamente. Em determinado momento, a transição geracional 
ocorre. Isso se dá quando uma geração sucede outra e vem a ocupar os papéis antes ocupados pela geração substituída.

A geração pode ser composta de um indivíduo em um determinado papel, como por exemplo, um presidente de uma organização. A presente geração é o indivíduo que hoje ocupa esse papel e a próxima geração será o indivíduo que ocupará esse papel no futuro. A geração também pode ser composta por um grupo de indivíduos, por exemplo, um grupo de trainees que ingressa ao mesmo tempo e na mesma posição na organização (WADE-BENZONI, 2002).

Wade-Benzoni (2002) defende em seu artigo a importância da reciprocidade moral no sentido da geração atual tratar a geração futura da mesma forma que ela gostaria de ter sido tratada pela geração anterior e analisa como diferentes relações entre gerações geram conflitos e impactam na efetividade organizacional.

Um exemplo do uso da face da identidade geracional baseada em coorte é o artigo publicado por Liu (2003). Ela constatou duas gerações em uma organização chinesa, a primeira formada por empregados que foram contratados antes de 1980, ano da reforma econômica da China, e a segunda pelos contratados após essa data. Apesar de os dois grupos terem vivido a mesma mudança, o novo regime trouxe impactos culturais distintos para o grupo que ingressou na organização após o evento. Esse artigo utiliza a face baseada em coorte, pois separa os indivíduos tendo como base o tempo de empresa e experiências de socialização, classificando-os como diferentes gerações dentro da organização estudada.

Apesar de alguns autores trabalharem com as faces baseadas em incumbência e coorte, a maioria dos autores encontrados na pesquisa bibliográfica para realização dessa dissertação utilizam a face baseada em idade, utilizando conceitos da sociologia e dividindo os indivíduos em diferentes gerações baseados em suas datas de nascimento. Essa também é a face que orienta essa dissertação.

Outra forma de explorar o impacto das gerações no ambiente de trabalho é observar a distribuição de indivíduos de diferentes gerações dentro de uma organização como uma característica da demografia organizacional e a geração como um atributo demográfico. Um atributo demográfico é qualquer característica relativamente estável de um indivíduo que 
pode ser usada para categorizá-lo. Os atributos demográficos tem importância nas decisões, comportamentos e ações porque eles são utilizados pelas pessoas como base de comparação social, gerando um padrão ou norma de comportamento (LAWRENCE; TOLBERT, 2007).

Quando um indivíduo dentro de uma organização se pergunta "O que acontece com um indivíduo como eu nessa organização?” ele geralmente olha para as demais pessoas e busca como base de comparação indivíduos que tenham atributos demográficos similares ao dele. As normas de comportamento surgem do julgamento compartilhado pelos membros da organização a respeito de comportamentos e ações relacionados a indivíduos com determinados atributos demográficos. Logo, essas normas afetam como as pessoas respondem e interagem com as outras (LAWRENCE; TOLBERT, 2007).

As respostas da organização a indivíduos de uma determinada demografia criam um padrão de comportamento que orienta o comportamento de outros indivíduos que compartilham essa característica, transmitindo mensagens que podem levar a diferentes respostas como maior ou menor comprometimento, busca de uma nova posição dentro ou fora da organização, atitudes discriminatórias, etc. (LAWRENCE; TOLBERT, 2007).

A demografia organizacional tem impacto direto da demografia nacional. O aumento da diversidade etária na sociedade, aumento da expectativa de vida e do tempo de permanência no mercado de trabalho geram mudanças nas normas demográficas e uma pressão sob a gestão das pessoas nas organizações no sentido de ampliar a necessidade de rever suas estratégias e práticas e de lidar com o conflito intergeracional emergente (DENCKER et al, 2008; BENSON; BROWN, 2011; CAPELLI, 2005).

Como um fator demográfico as gerações exercem influência nas organizações, na medida em que gera normas de comportamento esperadas impactando nas dinâmicas dos grupos e nos relacionamentos interpessoais. Cada geração tem características próprias que sustentam a criação de normas de comportamento que podem agir de forma a beneficiar ou prejudicar as estratégias e objetivos organizacionais. Dessa forma, a gestão das diferenças geracionais emerge como elemento de atenção no campo da administração. A área de gestão de pessoas pode exercer um papel importante através de políticas e práticas atualizadas e flexíveis que considerem diferentes expectativas dos trabalhadores, influenciando de modo que os impactos da diversidade sejam positivos para a organização. 


\subsubsection{Gerações atuais}

É senso comum entre os pesquisadores do assunto que existem quatro gerações atualmente coexistindo no ambiente de trabalho: os Veteranos, Baby Boomers, Geração X e Geração Y (UNITE et $a l, 2012$ ). Os autores diferem quanto às datas de nascimento que separam as gerações, mas não diferem significativamente quanto a suas características (VELOSO et al 2008).

Baseados em pesquisas conduzidas nos Estados Unidos, Dencker et al (2007) apontam as gerações e seus fatos históricos chave, conforme quadro 5.

Quadro 5 - Descrições das gerações contemporâneas nos Estados Unidos

\begin{tabular}{|c|}
\hline $\begin{array}{l}\text { Coorte da Depressão (nascidos de } 1912 \text { a 1921) } \\
\text { Eventos memoráveis: a grande depressão, altos níveis de desemprego, pobreza } \\
\text { Características-chave: busca de segurança financeira, aversão ao risco }\end{array}$ \\
\hline $\begin{array}{l}\text { Coorte da } 2^{\circ} \text { Guerra Mundial (nascidos de } 1922 \text { a 1927) } \\
\text { Eventos memoráveis: homens indo a Guerra e muitos não retornando, a experiência pessoal da Guerra, } \\
\text { mulheres trabalhando em fábricas, foco em defender-se de um inimigo comum } \\
\text { Características-chave: a nobreza do sacrifício pelo bem comum, patriotismo, trabalho em equipe }\end{array}$ \\
\hline $\begin{array}{l}\text { Coorte pós-guerra (nascidos de } 1928 \text { a 1945) } \\
\text { Eventos memoráveis: crescimento econômico sustentado, tranquilidade social, McCarthyism } \\
\text { Características-chave: conformidade, conservacionismo, valores familiares tradicionais }\end{array}$ \\
\hline $\begin{array}{l}\text { Coorte Baby boomer } \mathbf{n}^{\circ} \mathbf{1} \text { (nascidos de } \mathbf{1 9 4 6} \text { a 1954) } \\
\text { Eventos memoráveis: assassinato de John F. Kennedy, Robert Kennedy e Martin Luther King, homem na lua, } \\
\text { Guerra do Vietnã, protestos contra a guerra, experimentação social, liberdade sexual, movimento dos direitos } \\
\text { civis, movimento em prol do meio ambiente, movimento das mulheres, protestos e tumultos } \\
\text { Características-chave: experimental, individualismo, espírito livre, orientação a uma causa social }\end{array}$ \\
\hline $\begin{array}{l}\text { Coorte Baby boomer } \mathbf{n}^{\circ} \mathbf{2} \text { (nascidos de } 1955 \text { a 1964) } \\
\text { Eventos memoráveis: Watergate, renúncia de Nixon, Guerra fria, embargo ao petróleo, inflação crescente, } \\
\text { falta de gasolina } \\
\text { Características-chave: menos otimismo, desconfiança do governo, cinismo geral }\end{array}$ \\
\hline $\begin{array}{l}\text { Coorte Geração X (nascidos de } 1965 \text { a 1976) } \\
\text { Eventos memoráveis: explosão do Challenger, mal-estar social, AIDS, sexo seguro, queda do Muro de } \\
\text { Berlim, famílias de pais solteiros } \\
\text { Características-chave: busca por segurança emocional, independência, informalidade, empreendedorismo }\end{array}$ \\
\hline $\begin{array}{l}\text { Coorte da Geração Y (nascidos de } 1977 \text { até o presente) } \\
\text { Eventos memoráveis: ascensão da internet, ataque de } 11 \text { de setembro, diversidade cultural, duas guerras no } \\
\text { Iraque } \\
\text { Características-chave: busca por segurança física e patrimonial, patriotismo, medos exacerbados, aceitação da } \\
\text { mudança, conhecimento técnico }\end{array}$ \\
\hline
\end{tabular}

Fonte: DENCKER et al, 2007, p. 213 (tradução da autora)

Grande parte da produção sobre Gerações é norte-americana (UNITE et al, 2012). Considerando o conceito de Geração definido por Mannheim, faz-se necessário o estudo das gerações em contextos nacionais. Não é possível transpor descrições de gerações de outras nacionalidades e culturas para a realidade Brasileira sem o olhar dos fatos históricos, 
econômicos, políticos, sociais, demográficos e tecnológicos do país (PARRY; URWIN, 2010; DENCKER et al, 2008). UNITE et al (2012) puderam comprovar isso através de pesquisa empírica comparando a definição de sucesso de carreira de indivíduos de diferentes gerações em 11 países e observando que as diferenças culturais têm forte influência sobre as características das gerações de cada local.

O quadro 6 reúne os principais aspectos históricos, econômicos, tecnológicos, políticos e culturais que essas quatro gerações tiveram como fatores formadores no Brasil, utilizando-se os anos de separação entre gerações propostos por Amaral (2004), que tem pesquisado esse tema nos últimos dez anos no país. São apresentados os aspectos que influenciaram os jovens dessas gerações em seus processos de socialização. Esse é um levantamento teórico sobre essas divisões, sendo necessários estudos empíricos que comprovem esses fatos relevantes e identifiquem seus impactos nas respectivas gerações.

\section{Quadro 6 - Principais aspectos históricos, econômicos, tecnológicos, políticos e culturais formadores das} gerações no Brasil

\begin{tabular}{|c|c|}
\hline Geração & Principais aspectos históricos, econômicos, tecnológicos, políticos e culturais no Brasil \\
\hline $\begin{array}{l}\text { Veteranos } \\
(\mathbf{1 9 2 0 - 1 9 4 4 )}\end{array}$ & $\begin{array}{l}\text { Nascidos entre guerras e sob o signo do tenentismo, com visão de "ordem e progresso" } \\
\text { baseada em estratégias militares. Passaram a adolescência na Era Vargas, regime totalitarista } \\
\text { patriarcal. Vivenciaram a criação das leis do trabalho e tiveram acesso restrito a educação. } \\
\text { Momento de forte nacionalismo. Era mais importante ser alguém do que ter algo. }\end{array}$ \\
\hline $\begin{array}{l}\text { Baby } \\
\text { Boomers } \\
(\mathbf{1 9 4 5 - 1 9 6 0 )}\end{array}$ & $\begin{array}{l}\text { Protestaram contra a ditadura militar, se tornaram altamente politizados. Viveram um período } \\
\text { de forte industrialização e crescimento econômico com o milagre econômico. Viram o } \\
\text { nascimento do "rock \& roll" e da bossa nova. Na fase adulta viveram a repressão militar e a } \\
\text { década perdida, momento de estagnação econômica deflagrada pelo crash da bolsa de valores } \\
\text { de Nova York em 1987. Viveram o aumento da mão de obra feminina e o início da } \\
\text { emancipação das mulheres com a pílula anticoncepcional }\end{array}$ \\
\hline $\begin{array}{l}\text { Ge } \\
(19 \\
198\end{array}$ & $\begin{array}{l}\text { População urbana brasileira superou a rural na década de } 70 \text { aumentando tendência de } \\
\text { distanciamento entre as pessoas refletindo na enorme diversidade de tribos que coexistiam na } \\
\text { década de } 80 \text {. Surgimento da filosofia yuppie, que dava importância máxima ao dinheiro, e, de } \\
\text { outro lado, o movimento punk, com suas ideias anarquistas e desprezo pelo excesso de } \\
\text { conforto material. Cresceram vendo televisão. Forte influência da cultura americana após a } \\
\text { abertura do mercado nacional às importações. Forte internacionalização e onda de } \\
\text { privatizações e terceirizações. Movimentos de reengenharia e downsizing, reduzindo a } \\
\text { lealdade às organizações. Surgimento da AIDS, aumento da violência e do uso de drogas. } \\
\text { Frustração pelo fracasso dos planos econômicos para controle da inflação. }\end{array}$ \\
\hline $\begin{array}{l}\text { Gera } \\
(198\end{array}$ & $\begin{array}{l}\text { Cresceram com a TV a cabo, videogames, computadores, internet e telefones celulares em um } \\
\text { mundo eminentemente virtual e global. São os nativos digitais. Foram marcados pelo } 11 \text { de } \\
\text { setembro. Nasceram em um mundo globalizado. A partir dos anos } 2000 \text {, viveram o plano real } \\
\text { com uma moeda forte e estável, o aumento do poder de consumo, a consolidação da economia } \\
\text { e do comércio internacional. }\end{array}$ \\
\hline
\end{tabular}

Fonte: adaptado de AMARAL, 2004; CASADO, 2007; FLEURY; FISCHER, 1992; IKEDA et al, 2008; SILVA et al, 2011 
Quatro estudos internacionais longitudinais sobre gerações se destacam no sentido de comprovar a existência dos efeitos geracionais no comportamento e nos valores relacionados ao trabalho.

O primeiro é o de Smola e Sutton (2002) que fizeram uma pesquisa para analisar a diferenças geracionais de valores relacionados ao trabalho e como esses valores mudavam com o envelhecimento. Os autores observaram a atitude em relação ao trabalho de indivíduos em 1999 da geração X e Baby Boomers comparando com os resultados de um instrumento similar aplicado em 1974 também com indivíduos dessas gerações. Os resultados indicaram que os indivíduos da Geração X têm um desejo maior de serem promovidos mais rapidamente e tem uma crença menor de que o trabalho é a parte mais importante da vida. Eles concluíram que os valores relacionados a trabalho têm maior relação com a geração do que com efeitos de idade ou maturidade.

O segundo estudo longitudinal que se destaca é o de Twenge e Campbell (2008) que comparou os traços de personalidade da Geração Y com os de jovens de gerações anteriores, utilizando dados secundários coletados de artigos e dissertações desde 1930 que utilizaram as mesmas escalas aplicadas em jovens ao longo dos anos. Seus achados principais são que a Geração Y tem maior autoestima, narcisismo, ansiedade e depressão, menor necessidade de autoaprovação e um lócus de controle mais externo do que jovens de outras gerações.

O terceiro estudo é de Twenge et al (2010) que utilizaram dados de pesquisas realizadas em 1976, 1991 e 2006 com jovens americanos último-anistas do ensino médio sobre seus valores relacionados ao trabalho, representando Baby Boomers, a Geração X e a Geração Y em sua juventude, isolando efeitos de idade. Valores relacionados ao lazer aumentaram com o passar das gerações e os valores relacionados ao trabalho declinaram. Valores extrínsecos, tais como status e dinheiro, são mais altos para a Geração Y do que para os Baby Boomers. Ao contrário do divulgado na mídia, a Geração Y não privilegia valores altruístas (ajuda, valor social) no trabalho mais do que outras gerações. Os valores sociais, tais como fazer amigos, e valores intrínsecos, tais como, um trabalho interessante ou orientado ao resultado, foram avaliados com prioridade mais baixa para a Geração Y do que para Baby Boomers.

O quarto estudo é de Lippmann (2008) que analisou os dados colhidos bianualmente pelo censo norte-americano sobre desligamento e recolocação desde meados da década de 80, 
cobrindo informações de mais de 48.000 desligamentos involuntários, excluindo efeitos de maturidade e permitindo uma análise sobre as gerações. Os resultados comprovaram que a idade se torna significativa e negativamente relacionada com a duração do desemprego, mas a geração é indicada como um melhor preditor das consequências do desemprego do que a idade, incluindo a duração do desemprego e a chance de mudança de profissão durante a recolocação.

A autora justifica seus achados tendo como base a teoria institucional, pois indivíduos nascidos em um determinado tempo são socializados em um ambiente normativo que reflete padrões e estruturas institucionais vigentes. A mudança na forma de emprego e no contrato psicológico de trabalho que a nova economia trouxe fez com que os indivíduos que ingressaram no mercado de trabalho dentro do antigo contrato tivessem maior dificuldade de adaptação, gerando dificuldades em buscar novas posições.

O quadro 7 reúne os achados dos estudos longitudinais que comparam as características de diferentes gerações e excluem efeitos de maturidade e do período atribuindo suas conclusões exclusivamente ao efeito geracional, comprovando esse efeito empiricamente. Todos os estudos citados abaixo foram conduzidos nos Estados Unidos.

\section{Quadro 7 - Estudos longitudinais sobre gerações}

\begin{tabular}{|l|l|l|}
\hline \multicolumn{1}{|c|}{ Fonte } & Foco do estudo & \multicolumn{1}{c|}{ Achados } \\
\hline $\begin{array}{l}\text { Smola e } \\
\text { Sutton } \\
(2002)\end{array}$ & $\begin{array}{l}\text { Valores } \\
\text { relacionados ao } \\
\text { trabalho }\end{array}$ & $\begin{array}{l}\text { Indivíduos da Geração X têm um desejo maior de serem promovidos mais } \\
\text { rapidamente e tem uma crença menor de que o trabalho é a parte mais } \\
\text { importante da vida do que os Baby Boomers. Os valores relacionados ao } \\
\text { trabalho têm maior relação com a geração do que com efeitos de idade ou } \\
\text { maturidade. }\end{array}$ \\
\hline $\begin{array}{l}\text { Twenge e } \\
\text { Campbell } \\
(2008)\end{array}$ & $\begin{array}{l}\text { Traços de } \\
\text { Personalidade }\end{array}$ & $\begin{array}{l}\text { Geração Y tem maior autoestima, narcisismo, ansiedade e depressão, menor } \\
\text { necessidade de autoaprovação e um lócus de controle mais externo do que } \\
\text { jovens de outras gerações. }\end{array}$ \\
\hline $\begin{array}{l}\text { Twenge } e t \\
\text { al (2010) }\end{array}$ & $\begin{array}{l}\text { Valores } \\
\text { relacionados ao } \\
\text { trabalho }\end{array}$ & $\begin{array}{l}\text { Valores relacionados ao lazer aumentaram com o passar das gerações e os } \\
\text { valores relacionados ao trabalho declinaram. Valores extrínsecos, tais como } \\
\text { status e dinheiro, são mais altos para a Geração Y do que para os Baby } \\
\text { Boomers. A Geração Y não privilegia valores altruístas (ajuda, valor social) } \\
\text { no trabalho mais do que outras gerações. Os valores sociais, tais como fazer } \\
\text { amigos, e valores intrínsecos, tais como, um trabalho interessante ou } \\
\text { orientado ao resultado, foram avaliados com prioridade mais baixa para a } \\
\text { Geração Y do que para Baby Boomers. }\end{array}$ \\
\hline $\begin{array}{l}\text { Lippmann } \\
(2008)\end{array}$ & $\begin{array}{l}\text { Relação entre } \\
\text { geração e } \\
\text { desemprego }\end{array}$ & $\begin{array}{l}\text { gesemão é indicada como um melhor preditor das consequências do } \\
\text { de mudança de profissão durante a recolocação. }\end{array}$ \\
\hline
\end{tabular}


Obtendo resultados diferentes dos encontrados pelos autores citados acima, Pralong (2010), pesquisador francês, realizou um estudo com 400 indivíduos para comparação dos mapas mentais de três grupos. O primeiro era de estudantes de engenharia da Geração Y (nascidos entre 1979 e 1999) que nunca haviam trabalhado, o segundo era de engenheiros formados da geração Y que estavam no mercado de trabalho e o terceiro era de engenheiros da geração anterior que também estavam trabalhando. Os mapas mentais demonstram as formas que os indivíduos interpretam a realidade e abordam sua forma de agir. Apesar dos mapas serem individuais, eles são influenciados pelo contexto, cultura e socialização.

Nesse estudo, foram feitos os mapas mentais sobre o trabalho dos respondentes a partir de assertivas sobre esse tema e análise estatística das relações dessas assertivas, seguindo metodologia proposta pelo próprio autor. A pesquisa mostrou que a geração não proporciona diferenças nos padrões cognitivos relacionados com o emprego e a carreira, já que os resultados do primeiro grupo foram diferentes dos demais grupos e os dois outros grupos, ou seja, de trabalhadores das duas gerações diferentes, apresentavam similaridades, provando que o contexto do trabalho e a socialização no trabalho têm maior impacto sob os mapas cognitivos individuais do que a geração (PRALONG, 2010).

A escolha da mesma formação e profissão foi feita no estudo para minimizar outros efeitos culturais que poderiam causar divergências nos mapas cognitivos dos respondentes não advindos da geração, em uma tentativa de reduzir os erros de uma pesquisa comparativa entre gerações não-longitudinal. O pesquisador aponta a impossibilidade de generalização de seus resultados devido a amostra reduzida e a necessidade de uma pesquisa longitudinal para comprovação dos mesmos (PRALONG, 2010).

Os estudos acadêmicos nacionais sobre gerações e gestão de pessoas estão começando a surgir nos últimos anos. Os primeiros estudos procuram comparar as gerações e identificar semelhanças e diferenças quanto a valores, comprometimento organizacional e expectativas de carreira. Destaca-se o interesse pela geração Y, considerando o número de pesquisas conduzidas sobre essa geração.

Os autores brasileiros partem de uma breve definição de geração, utilizando diferentes referências, e aprofundam o tema descrevendo cada geração atual, basicamente citando bibliografia internacional, inclusive para definição dos anos de divisão das gerações. Nenhum 
dos estudos é longitudinal, logo não é possível distinguir os efeitos da geração dos efeitos da maturidade. Veloso et al (2011) e Pinho et al (2011) apontam a necessidade de pesquisas nacionais para aprofundamento do tema no Brasil.

Um dos primeiros estudos sobre a Geração Y foi conduzido por Coimbra e Schikmann (2001) e observou que apesar dessa geração ter forte relação com a tecnologia, a maioria (89\%) dos respondentes ainda trabalhava em empresas da velha economia. A maioria dos pesquisados consideraram um profissional de sucesso aquele que alcança seus objetivos, equilibra trabalho e vida pessoal e faz o que gosta. $O$ estudo foi quantitativo e envolveu 202 jovens universitários de São Paulo com idade entre 20 e 24 anos.

Veloso et al (2008) utilizaram a base de dados das "150 Melhores Empresas para Você Trabalhar", edição 2007, para identificar diferenças entre percepções das gerações sobre as competências das carreiras inteligentes: knowing-how, knowing-why e knowing-whom. Os pesquisadores identificaram que os Baby boomers percebem mais positivamente os três grupos de competências, principalmente o knowing-why, demonstrando maior grau de identificação com o trabalho; e que entre a Geração X e Y, a Y está mais favorável às afirmativas do knowing-how e knowing-whom, principalmente ligado a questões relacionadas a carreira e a X está mais favorável às afirmativas do knowing-why.

Vasconcelos et al (2009) buscaram identificar as âncoras de carreira de jovens do Espírito Santo nascidos a partir de 1978. A âncora com maior destaque foi Estilo de Vida, demonstrando a busca por oportunidades que permitam conciliar e integrar necessidades pessoais, familiares e as exigências da carreira.

Cavazotte et al (2010) publicaram um estudo qualitativo com 22 estudantes do Rio de Janeiro com idades entre 20 e 28 anos para explorar suas expectativas em relação ao trabalho em relação a recompensas tangíveis e intangíveis. Os pesquisadores encontraram expectativas iguais a de outras gerações, tais como, crescimento na empresa (mas com maior velocidade do que outras gerações), estabilidade e bom salário. Dentre as expectativas exclusivas da Geração Y, foram identificadas: desafios e dinamismo, prazer no trabalho, flexibilidade, qualidade de vida, reconhecimento e feedback, bom relacionamento com as pessoas, bom ambiente e o interesse em trabalhar em uma organização socialmente responsável. 
Em 2010, Silva et al (2011) realizaram uma pesquisa com 203 estudantes de pós-graduação para determinação das atitudes de carreira e análise da relação dessas atitudes com as características demográficas dessa amostra. Nesse estudo não foi possível a distinção estatística das atitudes de carreira proteana e sem fronteiras, mas foram identificadas diferenças associadas ao gênero e geração do respondente. Os Baby Boomers e Geração Y apresentaram proporção maior de respondentes no grupo das novas carreiras enquanto a Geração X se destacou na carreira tradicional.

Nogueira et al (2011) e Vale et al (2011) conduziram estudos para analisar as diferenças em termos de comprometimento organizacional de indivíduos de diferentes gerações utilizando o mesmo instrumento de coleta de dados, a Escala de Bases do Comprometimento Organizacional (EBACO). Nogueira et al (2011) compararam as gerações X e Y tendo como universo os 613 oficiais intendentes da aeronáutica, em diferentes cargos e níveis hierárquicos e Vale et al (2011) analisaram as diferenças entre as gerações Veteranos, Baby Boomers, X e Y tendo como amostra 116 servidores técnico-administrativos da Universidade Federal do Ceará em diferentes setores e ambientes da instituição pesquisada. O primeiro estudo apontou que os indivíduos da Geração Y apresentaram níveis mais baixos de comprometimento organizacional do que os da geração $\mathrm{X}$ em diversas bases, já o segundo estudo aponta que as diferenças geracionais não impactam nas bases de comprometimento dos sujeitos, mas sim apontam bases de comprometimento predominantes.

Veloso et al (2011) voltaram a pesquisar a relação entre a percepção sobre o desenvolvimento das competências das carreiras inteligentes e a percepção sobre crescimento profissional nas organizações, considerando as distintas preferências e visões de mundo das gerações Baby Boomers, X e Y. Entre as descobertas do estudo, é possível destacar que a percepção sobre a competência Knowing whom influencia mais a visão dos Baby Boomers sobre crescimento profissional, do que as pessoas das gerações X e Y. Concluiu-se então que os Baby Boomers utilizam melhor a influência política nas organizações do que as outras gerações. Por outro lado, as gerações X e Y, por serem mais questionadoras, apresentam influência mais positiva da percepção de Knowing why sobre sua percepção sobre crescimento profissional. Sobre a percepção de Knowing how, não foram constatadas diferenças entre as gerações quanto à sua influência sobre a percepção de crescimento profissional, pois tal influência é altamente positiva para as três gerações. 
A primeira meta análise da produção acadêmica nacional sobre a Geração Y foi desenvolvida em 2011 por Pinho et al (2011) com base na produção dos últimos dez anos. As autoras identificaram a pequena produção nacional sobre o tema e a grande e crescente quantidade de produção internacional, que utilizam surveys e técnicas estatísticas para análise dos resultados.

O quadro 8 reúne os principais achados dos estudos nacionais sobre Gerações. Para a presente dissertação, foram procurados artigos sobre gerações em periódicos acadêmicos nacionais, no entanto, apenas foram encontrados artigos publicados em congressos como o ENANPAD, SemeAd e EnGPR demonstrando o crescimento do interesse acadêmico e das pesquisas sobre gerações no campo de gestão de pessoas no Brasil.

\section{Quadro 8 - Estudos nacionais sobre gerações}

\begin{tabular}{|c|c|c|}
\hline Fonte & Tema & Principais Resultados \\
\hline $\begin{array}{l}\text { Coimbra e } \\
\text { Schikmann } \\
(2001)\end{array}$ & Geração Y no trabalho & $\begin{array}{l}\text { A maioria }(89 \%) \text { dos indivíduos da Geração Y trabalhava em } \\
\text { empresas da velha economia e consideraram um profissional de } \\
\text { sucesso aquele que alcança seus objetivos, equilibra trabalho e } \\
\text { vida pessoal e faz o que gosta. }\end{array}$ \\
\hline $\begin{array}{l}\text { Veloso et } \\
\text { al (2008) }\end{array}$ & $\begin{array}{l}\text { Percepção das gerações } \\
\text { sobre as competências das } \\
\text { carreiras inteligentes }\end{array}$ & $\begin{array}{l}\text { Os Baby boomers percebem mais positivamente os três grupos } \\
\text { de competências, principalmente o knowing-why, demonstrando } \\
\text { maior grau de identificação com o trabalho. Entre a Geração X e } \\
\text { Y, a Y está mais favorável às afirmativas do knowing-how e } \\
\text { knowing-whom, principalmente ligado a questões relacionadas à } \\
\text { carreira e a X está mais favorável às afirmativas do knowing- } \\
\text { why. }\end{array}$ \\
\hline $\begin{array}{l}\text { Vasconcel } \\
\text { os et al } \\
(2009)\end{array}$ & $\begin{array}{l}\text { Âncoras de carreira da } \\
\text { Geração Y }\end{array}$ & $\begin{array}{l}\text { A âncora com maior destaque foi Estilo de Vida, demonstrando } \\
\text { a busca por oportunidades que permitam conciliar e integrar } \\
\text { necessidades pessoais, familiares e as exigências da carreira. }\end{array}$ \\
\hline $\begin{array}{l}\text { Cavazotte, } \\
\text { et al } \\
(2010)\end{array}$ & $\begin{array}{l}\text { Expectativas em relação ao } \\
\text { trabalho quanto a } \\
\text { recompensas tangíveis e } \\
\text { intangíveis dos jovens da } \\
\text { Geração Y }\end{array}$ & $\begin{array}{l}\text { Dentre as expectativas exclusivas da Geração Y, foram } \\
\text { identificadas: desafios e dinamismo, prazer no trabalho, } \\
\text { flexibilidade, qualidade de vida, reconhecimento e feedback, } \\
\text { bom relacionamento com as pessoas, bom ambiente e o } \\
\text { interesse em trabalhar em uma organização socialmente } \\
\text { responsável. }\end{array}$ \\
\hline $\begin{array}{l}\text { Silva et al } \\
(2011)\end{array}$ & $\begin{array}{l}\text { Relação entre atitudes de } \\
\text { carreira e gerações }\end{array}$ & $\begin{array}{l}\text { Não foi possível a distinção estatística das atitudes de carreira } \\
\text { proteana e sem fronteiras. Os Baby Boomers e Geração Y } \\
\text { apresentaram proporção maior de respondentes no grupo das } \\
\text { novas carreiras enquanto a Geração X se destacou na carreira } \\
\text { tradicional. }\end{array}$ \\
\hline $\begin{array}{l}\text { Nogueira, } \\
\text { et al } \\
(2011) \\
\end{array}$ & \multirow{2}{*}{$\begin{array}{l}\text { Análise das diferenças em } \\
\text { termos de comprometimento } \\
\text { organizacional de indivíduos } \\
\text { de diferentes gerações } \\
\text { utilizando a Escala de Bases } \\
\text { do Comprometimento } \\
\text { Organizacional (EBACO) } \\
\end{array}$} & $\begin{array}{l}\text { Indivíduos da Geração Y apresentaram níveis mais baixos de } \\
\text { comprometimento organizacional do que os da geração X em } \\
\text { diversas bases. }\end{array}$ \\
\hline $\begin{array}{l}\text { Vale et al } \\
(2011)\end{array}$ & & $\begin{array}{l}\text { As diferenças geracionais não impactam nas bases de } \\
\text { comprometimento dos sujeitos, mas sim apontam bases de } \\
\text { comprometimento predominantes. }\end{array}$ \\
\hline $\begin{array}{l}\text { Veloso et } \\
\text { al (2011) }\end{array}$ & $\begin{array}{l}\text { Relação entre a percepção } \\
\text { sobre o desenvolvimento das } \\
\text { competências das carreiras }\end{array}$ & $\begin{array}{l}\text { A percepção sobre a competência Knowing whom influencia } \\
\text { mais a visão dos Baby Boomers sobre crescimento profissional, } \\
\text { do que as pessoas das gerações X e Y e eles utilizam melhor a }\end{array}$ \\
\hline
\end{tabular}




\begin{tabular}{|l|l|l|}
\hline \multicolumn{1}{|c|}{ Tema } & \multicolumn{1}{|c|}{ Principais Resultados } \\
\hline & $\begin{array}{l}\text { inteligentes e a percepção } \\
\text { sobre crescimento } \\
\text { profissional das diferentes } \\
\text { gerações }\end{array}$ & $\begin{array}{l}\text { influência política nas organizações do que as outras gerações. } \\
\text { Por outro lado, as gerações X e Y, por serem mais } \\
\text { questionadoras, apresentam influência mais positiva da } \\
\text { percepção de Knowing why sobre sua percepção sobre } \\
\text { crescimento profissional. Sobre a percepção de Knowing how, } \\
\text { não foram constatadas diferenças entre as gerações. }\end{array}$ \\
\hline $\begin{array}{l}\text { Pinho } \text { et al } \\
(2011)\end{array}$ & $\begin{array}{l}\text { Meta análise da produção } \\
\text { acadêmica nos últimos 10 } \\
\text { anos sobre a Geração Y }\end{array}$ & $\begin{array}{l}\text { Pequena produção nacional sobre o tema e grande e crescente } \\
\text { produção internacional, que utiliza surveys e técnicas } \\
\text { estatísticas para análise dos resultados. }\end{array}$ \\
\hline
\end{tabular}

Os artigos internacionais que tratam do tema geração são na maioria teóricos e utilizam autores da sociologia, tais como Mannheim, Ryder, Schuman e Scott, e da psicologia para estabelecer uma base conceitual sobre gerações. A profundidade técnica dos artigos internacionais é maior do que a dos artigos nacionais, pois eles trabalham mais sobre o conceito do que sobre as características de determinadas gerações. Os artigos teóricoempíricos internacionais utilizam análises longitudinais (SMOLA; SUTTON, 2002, TWENGE; CAMPBELL, 2008; TWENGE et al, 2010 e LIPPMANN, 2008) ou técnicas estatísticas que controlam o impacto da idade sobre o modelo (BENSON; BROWN, 2011), o que os coloca a frente dos estudos nacionais quanto ao método recomendado para estudo de gerações (PARRY; URWIN, 2010).

Uma pesquisa não acadêmica de destaque é a realizada pela Cia de Talentos há mais de dez anos intitulada "A empresa dos sonhos dos jovens" que investiga as organizações e características das organizações que os jovens desejam trabalhar e o que eles pensam sobre sucesso e liderança. A pesquisa 2011 contou com 40.445 respondentes no Brasil todo. A amostra foi composta por universitários e recém-formados com idade entre 17 e 28 anos (CIA DE TALENTOS, 2012). Os resultados da pesquisa revelam que os fatores que definem o sucesso para os jovens são relacionados com a capacidade de aproveitar as oportunidades e de fazer aquilo gosta.

Essa pesquisa também apontou que os principais motivos da escolha das melhores empresas estão relacionados à: desenvolvimento profissional, desafios, boa imagem no mercado, bom ambiente de trabalho e carreira internacional. Esses motivos podem ser analisados nos últimos 6 anos, conforme quadro 9. 
Quadro 9 - Motivos das escolhas das Empresas dos Sonhos dos Jovens nos últimos 6 anos

\begin{tabular}{|c|c|c|c|c|c|}
\hline 2006 & 2007 & 2008 & 2009 & 2010 & 2011 \\
\hline $\begin{array}{l}\text { Boa imagem } \\
\text { no mercado }\end{array}$ & Desafios & $\begin{array}{l}\text { Salários e } \\
\text { Benefícios }\end{array}$ & $\begin{array}{l}\text { Crescimento } \\
\text { Profissional }\end{array}$ & $\begin{array}{c}\text { Bom ambiente de } \\
\text { trabalho }\end{array}$ & $\begin{array}{c}\text { Desenvolvimento } \\
\text { Profissional }\end{array}$ \\
\hline $\begin{array}{l}\text { Salários e } \\
\text { Benefícios }\end{array}$ & $\begin{array}{l}\text { Crescimento } \\
\text { Profissional }\end{array}$ & $\begin{array}{l}\text { Crescimento } \\
\text { Profissional }\end{array}$ & $\begin{array}{c}\text { Desenvolvimen- } \\
\text { to Profissional }\end{array}$ & $\begin{array}{l}\text { Desenvolvimento } \\
\text { Profissional }\end{array}$ & Desafios \\
\hline Desafios & $\begin{array}{l}\text { Boa intra- } \\
\text { estrutura }\end{array}$ & $\begin{array}{l}\text { Boa imagem } \\
\text { no mercado }\end{array}$ & $\begin{array}{c}\text { Bom ambiente } \\
\text { de trabalho }\end{array}$ & Qualidade de vida & $\begin{array}{c}\text { Boa imagem no } \\
\text { mercado }\end{array}$ \\
\hline $\begin{array}{c}\text { Negócio onde } \\
\text { atua }\end{array}$ & $\begin{array}{c}\text { Boa imagem } \\
\text { no mercado }\end{array}$ & $\begin{array}{c}\text { Cursos e } \\
\text { Treinamentos }\end{array}$ & $\begin{array}{c}\text { Bons salários e } \\
\text { Benefícios }\end{array}$ & $\begin{array}{l}\text { Crescimento } \\
\text { Profissional }\end{array}$ & $\begin{array}{c}\text { Bom ambiente de } \\
\text { trabalho }\end{array}$ \\
\hline $\begin{array}{c}\text { Cursos e } \\
\text { Treinamentos } \\
\end{array}$ & $\begin{array}{l}\text { Salários e } \\
\text { Benefícios } \\
\end{array}$ & $\begin{array}{c}\text { Qualidade de } \\
\text { Vida } \\
\end{array}$ & $\begin{array}{c}\text { Cursos e } \\
\text { Treinamentos } \\
\end{array}$ & $\begin{array}{c}\text { Boa imagem no } \\
\text { mercado }\end{array}$ & $\begin{array}{c}\text { Carreira } \\
\text { internacional }\end{array}$ \\
\hline
\end{tabular}

Fonte: adaptado de CIA DE TALENTOS, 2011; CIA DE TALENTOS, 2012

Analisando o quadro 9, observa-se que ao longo dos últimos seis anos essa sequência tem se alterado e a prioridade da imagem no mercado e dos benefícios tangíveis têm ocupado posições inferiores na lista e os aspectos do ambiente de trabalho e do desenvolvimento profissional tem sido mais valorizados, demonstrando uma tendência de valorização de benefícios intangíveis e da busca da realização, desenvolvimento e bem-estar no trabalho.

A ausência desses elementos valorizados são os principais motivos apontados na pesquisa para que os jovens deixem as organizações. Apenas 5\% dos jovens apontaram a remuneração como fator de estímulo à saída (EMPRESAS, 2010).

Com base em sua experiência profissional desenvolvida ao longo de anos de coordenação da pesquisa "Empresas dos Sonhos dos Jovens" e na direção da Cia de Talentos, Amaral (2004) propõe a divisão e características das gerações no Brasil conforme quadro 10:

Quadro 10 - Características das gerações no Brasil

\begin{tabular}{|l|l|l|l|}
\hline & Baby Boomers & Geração X & Geração Y \\
\hline $\begin{array}{l}\text { Ano de } \\
\text { nascimento }\end{array}$ & 1945-1960 & $1961-1980$ & $1981-?$ \\
\hline Valores & $\begin{array}{l}\text { Trabalho em primeiro lugar. } \\
\text { Preocupação com } \\
\text { estabilidade financeira para } \\
\text { não ter privações como os } \\
\text { pais tiveram. }\end{array}$ & $\begin{array}{l}\text { Individualistas, necessidade } \\
\text { de comunicar suas ideias e } \\
\text { sentimentos. }\end{array}$ & $\begin{array}{l}\text { Agem, pensam e tomam } \\
\text { decisões na velocidade de } \\
\text { computadores de última } \\
\text { geração. Tudo é temporário e } \\
\text { moldável, inclusive estilos de } \\
\text { vida, crenças e convicções. }\end{array}$ \\
\hline
\end{tabular}




\begin{tabular}{|c|c|c|c|}
\hline & Baby Boomers & Geração X & Geração Y \\
\hline $\begin{array}{l}\text { No } \\
\text { trabalho }\end{array}$ & $\begin{array}{l}\text { Redução de níveis } \\
\text { hierárquicos por mudanças } \\
\text { estruturais. Viveram o } \\
\text { downsizing dos anos } 80 \text { e } 90 \text {. }\end{array}$ & $\begin{array}{l}\text { Além de um bom salário, } \\
\text { buscavam prazer e sentido } \\
\text { nas tarefas que realizavam. } \\
\text { Desenvolveram autonomia e } \\
\text { autossuficiência no trabalho. } \\
\text { Buscam apoio com } \\
\text { liberdade. Necessidade de } \\
\text { encontrar sentido nas } \\
\text { pequenas coisas cotidianas, } \\
\text { de ter feedback constante } \\
\text { sobre o que estão } \\
\text { produzindo e criando. } \\
\text { Precisam saber como e por } \\
\text { que devem trabalhar em } \\
\text { determinado projeto. }\end{array}$ & $\begin{array}{l}\text { Expectativa de "queimar etapas" } \\
\text { e crescer rapidamente. Esperam } \\
\text { que os líderes pratiquem o que } \\
\text { pregam, sejam coerentes com } \\
\text { seus discursos e cumpram as } \\
\text { promessas estabelecidas. } \\
\text { Precisam de supervisão com } \\
\text { liberdade. Gostam de trabalhar } \\
\text { com pessoas idealistas e } \\
\text { empenhadas e prezam empresas } \\
\text { que se preocupam com as } \\
\text { questões sociais e a preservação } \\
\text { do planeta. }\end{array}$ \\
\hline Família & $\begin{array}{l}\text { Família em segundo plano, o } \\
\text { trabalho vinha primeiro. As } \\
\text { mulheres começam a entrar } \\
\text { no mercado de trabalho. }\end{array}$ & $\begin{array}{l}\text { Pais focados no trabalho e } \\
\text { mães trabalhando fora. } \\
\text { Tiveram que aprender a se } \\
\text { virar sozinhos. }\end{array}$ & $\begin{array}{l}\text { Pais próximos e protetores. } \\
\text { Filhos únicos. }\end{array}$ \\
\hline $\begin{array}{l}\text { Caracte- } \\
\text { rísticas }\end{array}$ & $\begin{array}{l}\text { - Engajar-se em questões } \\
\text { políticas; } \\
\text { - Crer no progresso } \\
\text { econômico e social; } \\
\text { - Gerir por consenso; } \\
\text { - Ser otimista; } \\
\text { - Ser obcecado pelo } \\
\text { trabalho, mesmo em } \\
\text { detrimento da vida familiar; } \\
\text { - Achar-se capaz de resolver } \\
\text { tudo sozinho. }\end{array}$ & $\begin{array}{l}\text { - Autoconfiança e ceticismo; } \\
\text { - Tentar equilibrar vida } \\
\text { profissional e familiar; } \\
\text { - Cumprir objetivos; } \\
\text { - Ser informal no modo de } \\
\text { vestir-se e de relacionar-se } \\
\text { com as pessoas; } \\
\text { - Ter aversão a estruturas } \\
\text { hierárquicas muito rígidas } \\
\text { - Buscar trabalhos que lhe } \\
\text { permitam ter liberdade de } \\
\text { pensar e agir por conta } \\
\text { própria. }\end{array}$ & $\begin{array}{l}\text { - Otimismo em relação ao } \\
\text { futuro; } \\
\text { - Rejeição a categorizações de } \\
\text { raça, cor, religião e nível social; } \\
\text { - Rapidez de raciocínio; } \\
\text { - Capacidade de fazer mais de } \\
\text { uma coisa ao mesmo tempo; } \\
\text { - Absorção de um grande } \\
\text { número de informações; } \\
\text { - Certo grau de dificuldade de } \\
\text { correlacionar conteúdos; } \\
\text { - Exigir que seus líderes } \\
\text { pratiquem o que pregam } \\
\text { - Não abrir mão de tempo livre } \\
\text { para lazer e ócio; } \\
\text { - Ser apolíticos. }\end{array}$ \\
\hline
\end{tabular}

Fonte: adaptado de AMARAL, 2004

Observando o quadro acima, fica claro que as diferentes gerações têm percepções e atitudes diferentes em relação ao trabalho e a carreira. Os Baby Boomers demonstram um forte compromisso com o trabalho e procuram estabilidade e segurança nessa relação. A Geração X busca um trabalho que tenha um sentido claro, com autonomia e liberdade e inicia o movimento de busca de equilíbrio entre vida profissional e pessoal. Já a Geração Y tem uma visão mais acelerada da carreira e busca identificação com o trabalho, com uma tendência a mobilidade no caso de insatisfação ou percepção de um ambiente com incoerência entre o que se diz e o que se pratica (AMARAL, 2004).

Os estudos nacionais, com exceção do realizado pela Cia de Talentos, utilizam como referência estudos internacionais para definição das gerações, seus valores e características, 
tendo como data de corte para a Geração Y o ano de 1977 ou 1978. Nem mesmo os estudos internacionais apresentam convergência quanto aos anos de início e término de cada geração (PARRY; URWIN, 2010).

Parry e Urwin (2010) recomendam a consideração da cultura nacional para determinação das gerações, baseada em marcos históricos, econômicos, políticos e sociais. Buscando atender a essa recomendação, esse estudo utilizou as datas limites das gerações propostas por Amaral (2004) como sendo representativa da realidade brasileira, pois é baseada em uma pesquisa nacional, longitudinal que possui um número expressivo de respondentes.

Nas pesquisas internacionais consultadas, os trabalhos sobre gerações realizados nos Estados Unidos e Europa têm como foco principal o envelhecimento da população (aging population), buscando analisar a continuidade das pessoas que estão em idade de se aposentar no mercado de trabalho. Esse interesse é fundamentado pela inversão da pirâmide etária desses países, que traz impactos na economia, na previdência, em gastos com saúde e também na produtividade das organizações, devido a redução da força de trabalho em idade economicamente ativa. Profissionais e especialistas de RH colocam o grande número de Baby Boomers deixando as organizações ao mesmo tempo como sexta prioridade em gestão de pessoas internacional para 2011 (SHRM, 2011).

Entretanto, nas pesquisas nacionais consultadas para esse estudo, encontrou-se uma concentração de artigos sobre as gerações mais novas e a entrada delas no mercado de trabalho, confirmando a pesquisa sobre Tendências em Gestão de Pessoas nas Empresas Brasileiras que colocam a integração das diferentes gerações no trabalho como quinto tema mais relevante como tendência para a gestão de pessoas em 2015 no Brasil (FISCHER; ALBUQUERQUE, 2011).

O estudo das diferenças geracionais no trabalho e seu impacto na gestão de pessoas mostrouse um amplo campo de estudo para a Administração, na busca da redução dos impactos do choque geracional e no desenvolvimento de um ambiente de trabalho agradável e produtivo a indivíduos de diferentes gerações. Em especial, é um campo fértil de estudos para a gestão de carreiras, já que indivíduos de diferentes gerações tem diferentes comportamentos e valores relacionados ao trabalho, desenvolvendo novos olhares e possibilidades para sua carreira e oferecendo novos desafios às organizações no sentido da atração e retenção de talentos. 


\subsection{Carreira e gerações}

A gestão de carreiras é o espaço de mediação das expectativas dos indivíduos e das organizações, logo, é espaço de diálogo e de compreensão das diferenças. Inserir o tema geração nessa análise proporciona mais uma abordagem para o maior entendimento das expectativas de diferentes atores de carreira e o desenvolvimento de soluções em gestão de pessoas mais adequadas a essas expectativas, ampliando a efetividade da gestão de carreiras e da gestão de pessoas dentro das organizações.

A crescente preocupação de profissionais em gestão de pessoas no Brasil e no mundo com as questões demográficas, principalmente com a questão das gerações, aponta a necessidade do diálogo entre esses dois campos de estudo. As dificuldades em gerir uma força de trabalho diversa do ponto de vista geracional, em adequar as práticas e políticas da organização a essa nova realidade, em reter os talentos são temas frequentemente discutidos nas organizações e na mídia.

Diversos autores descrevem a necessidade de mais estudos sobre as diferenças entre gerações e seus efeitos no trabalho (VELOSO et al, 2011; PARRY; URWIN, 2010; JOSHI et al, 2010, BENSON; BROWN, 2011). O campo de carreira também sofre escassez de estudos nacionais (VELOSO, 2009). O desenvolvimento de pesquisas empíricas sobre esses temas colaboram para a evolução desses campos de estudo proporcionando bases e questões para pesquisas futuras.

As teorias modernas de carreira foram desenvolvidas para explicar os movimentos dos trabalhadores no mundo atual. Elas têm como base o momento econômico, político, social e tecnológico vigente. As dimensões principais dessas teorias são reflexo da modernidade. Por outro lado, tem-se um grupo grande de trabalhadores que estão nesse momento ingressando no mercado de trabalho e que só conhecem essa realidade e, consequentemente, são altamente influenciados por ela, são os jovens da Geração Y.

Existe uma relação direta entre a evolução das teorias de carreira e as descrições das gerações. Fazendo um paralelo com as teorias modernas de carreira, observa-se que as novas teorias 
surgem na entrada da Geração X no ambiente de trabalho e se posiciona com maior força durante o ingresso da Geração Y. Essa relação fica clara ao observar a fonte comum, ou seja, os movimentos socioeconômicos que impactaram o mercado de trabalho e também o ambiente em que esses indivíduos estavam formando sua identidade profissional.

Por exemplo, um indivíduo da Geração Y que vê seus pais serem demitidos repentinamente em um momento de reestruturação, após longos anos de dedicação ao trabalho e à organização, desenvolve valores e uma relação diferente com o trabalho. A premissa de que o trabalho está em primeiro lugar e o comprometimento com a organização defendidos por seus pais passam para um segundo plano e o individualismo e a busca de satisfação e aprendizado no trabalho sobem para primeiro plano (AMARAL, 2004).

Briscoe et al (2012), ao realizarem uma pesquisa envolvendo diversos países, observaram que o fenômeno da quebra do contrato psicológico é presente principalmente em países que foram fortemente afetados por crises econômicas, como aconteceu com o Brasil. Esse estudo concluiu que países que viveram essas crises fizeram com os mais jovens vivenciassem um ambiente de trabalho diferente dos mais velhos, trazendo maior divergência entre esses grupos quanto a percepção de carreira do que indivíduos de diferentes gerações em países de maior estabilidade econômica.

A teoria de gerações indica que as novas gerações caminham para modelos modernos de carreira. Briscoe et al (2012) encontraram evidências de que os indivíduos mais jovens de diversos países apresentam autodirecionamento em suas definições de sucesso de carreira e maior interesse em gerenciar suas próprias carreiras. Resultados de pesquisas nacionais apontam a busca pela realização e satisfação no trabalho e pelo equilíbrio entre vida pessoal e profissional entre os jovens. No entanto, esses são estudos iniciais e ainda existe pouco conhecimento sobre como diferentes grupos etários e diferentes gerações vivenciam suas carreiras, sendo esse um campo amplo de estudos.

Um estudo recente conduzido por um grupo internacional de pesquisa sobre carreira e cultura analisou as diferenças entre novas gerações e antigas gerações em diferentes contextos nacionais (BRISCOE et al, 2012). Apesar de não ser possível separar as diferenças entre os efeitos da maturidade e da geração, pois a pesquisa foi transversal, os achados indicam 
hipóteses a serem testadas em estudos futuros. Os principais achados estão resumidos no quadro 11.

Quadro 11 - Diferenças entre antigas e novas gerações em relação à carreira em diferentes contextos nacionais

\begin{tabular}{|c|l|l|}
\hline $\begin{array}{c}\text { Aspecto da } \\
\text { Carreira }\end{array}$ & \multicolumn{1}{|c|}{ Antigas Gerações } & \multicolumn{1}{c|}{ Novas Gerações } \\
\hline \multirow{3}{*}{$\begin{array}{c}\text { Sucesso na } \\
\text { Carreira }\end{array}$} & $\begin{array}{l}\text { Temas heterogêneos relacionados a sucesso } \\
\text { na carreira }\end{array}$ & $\begin{array}{l}\text { Grupo mais homogêneo quanto a importância } \\
\text { da autorrealização como um elemento principal } \\
\text { do sucesso na carreira }\end{array}$ \\
\cline { 2 - 3 } & $\begin{array}{l}\text { Países que sofreram grandes mudanças socioeconômicas apresentaram maiores diferenças } \\
\text { entre as respostas entre a antiga e nova geração }\end{array}$ \\
\hline $\begin{array}{c}\text { Transição } \\
\text { de } \\
\text { Carreira }\end{array}$ & $\begin{array}{l}\text { Transição orientada e motivada mais por } \\
\text { motivos extrínsecos. Ex.: reestruturação, } \\
\text { mudanças na liderança }\end{array}$ & $\begin{array}{l}\text { Transição orientada e motivada mais pelos } \\
\text { motivos intrínsecos. Ex.: desejo de fazer algo } \\
\text { novo, desenvolvimento }\end{array}$ \\
\hline
\end{tabular}

Fonte: adaptado de BRISCOE et al, 2012

Esse estudo também indicou que os membros mais jovens vivenciavam suas carreiras de modo mais similar entre diferentes países do que os mais velhos. Essa diferença é atribuída à tecnologia que gera uma linguagem universal e cria experiências em comum entre jovens do mundo todo, no entanto, ainda foram encontradas diferenças entre países, demonstrando pouca evidência de uma geração global entre os respondentes. Uma implicação desse achado é que os empregadores podem aplicar mais métodos universais de gestão de carreira e gestão de pessoas para seus empregados mais jovens do que para os mais velhos (BRISCOE et al, 2012).

Os resultados da pesquisa sugerem que abordagens de carreira e de remuneração genéricas não serão suficientes para motivar e reter trabalhadores de todas as idades e culturas. $\mathrm{O}$ uso de práticas de remuneração, de práticas de carreira e de benefícios flexíveis reconhecem as diferenças individuais e pode ajudar na atração e retenção de pessoas talentosas.

Nesse sentido, a perspectiva contextual sugerida por Briscoe et al (2012) para tratar da carreira, traz luz a essas diferenças, destacando a importância do ambiente externo para a definição e percepção de carreira em cada cultura nacional e para cada geração.

Entende-se que se existem diferenças entre gerações, esses indivíduos têm expectativas e atitudes diversas em relação a suas carreiras e, consequentemente, as organizações devem adotar estratégias e perspectivas para assumir sua função de mediação dessa variedade de 
expectativas. Dessa forma, a organização pode desenvolver de forma efetiva sua função de atração e retenção de talentos que garantirá sua produtividade e lucratividade no longo prazo.

\subsection{Síntese da revisão da literatura}

Buscando sintetizar a revisão da literatura feita para a presente dissertação, abaixo serão descritas as principais definições e referências para a pesquisa realizada e para a análise de dados.

\section{Carreiras}

De acordo com Hall (2002, p. 12): “A carreira é a sequência individualmente percebida de atitudes e comportamentos associados com experiências e atividades relacionadas ao trabalho durante a vida de uma pessoa.”.

Considerando as mudanças advindas pela Nova Economia, tais como, a descentralização da força de trabalho de grandes organizações para organizações menores, redução de níveis hierárquicos e da autoridade e o crescente número de movimentações de indivíduos entre organizações, Arthur (1994) e Hall (2002) buscaram reposicionar o conceito de carreira adaptando-o a essa nova realidade e propondo duas teorias e carreira:

\section{Quadro 12 - Síntese dos conceitos de carreira sem fronteiras e de carreira proteana}

\begin{tabular}{|c|c|}
\hline $\begin{array}{l}\text { Carreira sem fronteiras } \\
\text { Michael Arthur (1994) }\end{array}$ & $\begin{array}{c}\text { Carreira Proteana } \\
\text { Douglas Hall (2002) }\end{array}$ \\
\hline $\begin{array}{l}\text { - Destaca a mobilidade, ou seja, o interesse em } \\
\text { movimentar-se entre empregadores e a atitude geral } \\
\text { de trabalhar além das fronteiras organizacionais } \\
\text { - O ator de carreira é influenciado pelo ambiente, } \\
\text { mas também influencia o ambiente } \\
\text { - A carreira é apoiada por redes de fora da } \\
\text { organização, reconhece que relações familiares e } \\
\text { pessoais têm um impacto significativo } \\
\text { - A carreira deve ser interpretada de forma subjetiva } \\
\text { pelo próprio ator }\end{array}$ & $\begin{array}{l}\text { - Destaca a prioridade dos indivíduos em fazer } \\
\text { escolhas de carreira relacionadas a seus valores } \\
\text { pessoais e na autogestão de sua carreira. } \\
\text { - A carreira é caracterizada pela mudança frequente } \\
\text { e autoinvenção, autonomia e autogestão - } \\
\text { direcionadas pelas necessidades do indivíduo ao } \\
\text { invés da necessidade da organização. } \\
\text { - Para que o ator de carreira proteana tenha sucesso } \\
\text { em sua carreira é necessário que ele seja altamente } \\
\text { flexível e adaptativo. } \\
\text { - A identidade e a autoconsciência funcionam como } \\
\text { uma bússola interna para as decisões de carreira }\end{array}$ \\
\hline
\end{tabular}


Briscoe et al (2006) propõem uma forma empírica de analisar os modelos de carreira proteana e sem fronteiras. Os autores desenvolveram e validaram um modelo com quatro escalas para medir atitudes de carreira proteana e sem fronteiras. $\mathrm{O}$ quadro 13 descreve as dimensões de carreira sem fronteiras e proteana:

\section{Quadro 13 - Síntese das dimensões da carreira sem fronteiras e da carreira proteana}

\begin{tabular}{|l|l|}
\hline \multicolumn{1}{|c|}{ Carreira sem fronteiras } & \multicolumn{1}{|c|}{ Carreira Proteana } \\
\hline $\begin{array}{l}\text { Mobilidade psicológica: a mentalidade sem } \\
\text { fronteiras, ou seja, a atitude geral do indivíduo de } \\
\text { trabalhar além das fronteiras organizacionais, } \\
\text { demonstrando interesse em interagir com pessoas de } \\
\text { fora da organização, em ter novas experiências e } \\
\text { aprendizado constante. }\end{array}$ & $\begin{array}{l}\text { Autodirecionamento: a gestão da carreira } \\
\text { direcionada pelo indivíduo que cria suas próprias } \\
\text { oportunidades de desenvolvimento e desenvolve a } \\
\text { habilidade de se adaptar em termos de demandas de } \\
\text { desempenho. }\end{array}$ \\
\hline $\begin{array}{l}\text { Mobilidade física: a preferência de mobilidade } \\
\text { organizacional, ou seja, o nível de interesse em se } \\
\text { mover entre diferentes empregadores. }\end{array}$ & $\begin{array}{l}\text { Orientação pelos valores pessoais: o indivíduo } \\
\text { prioriza seus valores pessoais ao estabelecer } \\
\text { prioridades, objetivos e tomar suas decisões de } \\
\text { carreira. Os valores pessoas mensuram o sucesso na } \\
\text { carreira ao invés de motivadores extrínsecos como } \\
\text { cargo, salário, etc. }\end{array}$ \\
\hline
\end{tabular}

Fonte: adaptado de BRISCOE et al, 2006

Em uma tentativa de tornar esses conceitos mais acessíveis para indivíduos e organizações, Briscoe e Hall (2006) propuseram perfis de carreiras que utilizam combinações entre as duas dimensões da carreira proteana e as duas dimensões da carreira sem fronteiras. Esses perfis facilitam a identificação por parte dos indivíduos de suas próprias identidades e oportunidades de carreira, colocando em prática esses constructos. São sugeridos oito perfis de carreira baseados na combinação mais prováveis, considerando a experiência prática dos autores.

O mapeamento dos perfis de carreira permite o desenvolvimento por parte das organizações de soluções adequadas a essas pessoas com a revisão de seus processos, programas de desenvolvimento, programas de remuneração, pacotes de benefícios e planos de carreira e de retenção.

\section{Geração}

O conceito de geração indicado pela literatura como mais influente atualmente (FEIXA; LECCARDI, 2010; PARRY; URWIN, 2010, WELLER, 2010; DENCKER et al, 2007; EDMUNDS; TURNER, 2005) é o de Mannheim (1993). De acordo o autor, geração é parte 
do processo histórico que jovens da mesma idade-classe de fato compartilham. A data de nascimento é potencial para isso, mas não define a geração. Existem dois elementos centrais para a constituição de uma geração: presença de eventos que quebram a continuidade histórica e a vivência desse momento por membros de um grupo etário durante seu processo de socialização (adolescência e início da idade adulta), predispondo-os a certos modos de pensar e experiências.

Os efeitos da geração devem ser separados dos efeitos de idade (resultantes da faixa etária e amadurecimento do indivíduo) e dos efeitos do período (impactos do ambiente) para uma análise efetiva (DENCKER et al, 2007). Existe uma dificuldade metodológica em separar esses distintos efeitos. Para minimizar essa dificuldade, Parry e Urwin (2010) recomendam estudos longitudinais para determinação de efeitos geracionais.

As gerações podem variar de acordo com o contexto nacional, pois indivíduos em diferentes países vivem momentos históricos, sociais, econômicos e culturais distintos, o que pode interferir nas características e separações entre gerações (PARRY; URWIN, 2010; UNITE et al, 2012).

É senso comum entre os pesquisadores do assunto que existem quatro gerações atualmente coexistindo no ambiente de trabalho: os Veteranos, Baby Boomers, Geração X e Geração Y (UNITE et al, 2012). Os jovens nascidos a partir de 1981 são classificados como Geração Y, de acordo com classificação proposta para o Brasil por Amaral (2004).

Diversos aspectos culturais, sociais e políticos trazem diferenças para essas gerações. A geração Y tem como principal aspecto que a distingue das demais o fato de ter crescido em um ambiente digital (com a presença de computadores, celulares, internet, etc.) e, por esse motivo, Tapscott (2010) a chama de Geração Internet. A globalização e os meios modernos de comunicação, principalmente, a internet, ampliaram as possibilidades de participação de jovens de diferentes países em um conjunto de acontecimentos e experiências semelhantes colocando-os em uma mesma posição geracional (TAPSCOTT, 2010; EDMUNDS; TURNER, 2005).

Os estudos acadêmicos nacionais sobre Gerações e Gestão de Pessoas estão começando a surgir nos últimos anos. Os primeiros estudos têm como foco a comparação das gerações e a 
identificação de semelhanças e diferenças quanto a valores, comprometimento organizacional e expectativas de carreira. Existe um interesse maior pela geração Y, de acordo com o número de publicações nos últimos anos. Os autores brasileiros partem de uma breve definição de geração, utilizando diferentes referências, e aprofundam o tema descrevendo cada geração atual, basicamente citando bibliografia internacional, inclusive para definição dos anos de divisão das gerações. Nenhum dos estudos acadêmicos nacionais é longitudinal, logo não é possível distinguir os efeitos de geração dos efeitos de idade.

Os artigos internacionais que tratam do tema geração são na maioria teóricos e utilizam autores da sociologia, tais como Mannheim, Ryder, Schuman e Scott, e da psicologia para estabelecer a base conceitual. A profundidade técnica dos artigos internacionais é maior do que a dos artigos nacionais, pois eles trabalham mais sobre o conceito do que sobre as características de determinadas gerações. Os artigos teórico-empíricos internacionais utilizam análises longitudinais (SMOLA; SUTTON, 2002, TWENGE; CAMPBELL, 2008; TWENGE et al, 2010 e LIPPMANN, 2008) ou técnicas estatísticas que controlam o impacto da idade sobre o modelo (BENSON; BROWN, 2011), o que os coloca a frente dos estudos nacionais quanto ao método recomendado para estudo de gerações (PARRY; URWIN, 2010).

O quadro 14 resume os principais achados de estudos nacionais e internacionais sobre a Geração Y e gestão de pessoas.

Quadro 14 - Síntese dos principais achados de estudos nacionais e internacionais sobre a Geração Y e gestão de pessoas

\begin{tabular}{|l|l|l|}
\hline \multicolumn{1}{|c|}{ Autor } & $\begin{array}{l}\text { Característi- } \\
\text { ca do Estudo }\end{array}$ & \multicolumn{1}{c|}{ Achados sobre a Geração Y } \\
\hline $\begin{array}{l}\text { Twenge e } \\
\text { Campbell } \\
(2008)\end{array}$ & $\begin{array}{l}\text { Internacional, } \\
\text { longitudinal, } \\
\text { quantitativo }\end{array}$ & $\begin{array}{l}\text { A geração Y tem maior autoestima, narcisismo, ansiedade e depressão, } \\
\text { menor necessidade de autoaprovação e um lócus de controle mais externo do } \\
\text { que jovens de outras gerações }\end{array}$ \\
\hline $\begin{array}{l}\text { Twenge } \text { et al } \\
(2010)\end{array}$ & $\begin{array}{l}\text { Internacional, } \\
\text { longitudinal, } \\
\text { quantitativo }\end{array}$ & $\begin{array}{l}\text { Valores relacionados ao lazer aumentaram com o passar das gerações e os } \\
\text { valores relacionados ao trabalho declinaram. Valores extrínsecos, tais como } \\
\text { status e dinheiro, são mais altos para a Geração Y do que para os Baby } \\
\text { Boomers. A Geração Y não privilegia valores altruístas (ajuda, valor social) } \\
\text { no trabalho mais do que outras gerações. Os valores sociais, tais como fazer } \\
\text { amigos, e valores intrínsecos, tais como, um trabalho interessante ou } \\
\text { orientado ao resultado, foram avaliados com prioridade mais baixa para a } \\
\text { Geração Y do que para Baby Boomers. }\end{array}$ \\
\hline $\begin{array}{l}\text { Lippmann } \\
(2008)\end{array}$ & $\begin{array}{l}\text { Internacional, } \\
\text { longitudinal, } \\
\text { quantitativo }\end{array}$ & $\begin{array}{l}\text { Os jovens da Geração Y se recolocam mais rápido após o desemprego e tem } \\
\text { menor chance de mudança de profissão durante a recolocação do que jovens } \\
\text { de outras gerações. }\end{array}$ \\
\hline $\begin{array}{l}\text { Coimbra e } \\
\text { Schikmann } \\
(2001)\end{array}$ & $\begin{array}{l}\text { Nacional, } \\
\text { transversal, } \\
\text { quantitativo }\end{array}$ & $\begin{array}{l}\text { Jovens da Geração Y consideraram um profissional de sucesso aquele que } \\
\text { alcança seus objetivos, equilibra trabalho e vida pessoal e faz o que gosta. }\end{array}$ \\
\hline
\end{tabular}




\begin{tabular}{|c|c|c|}
\hline Autor & $\begin{array}{l}\text { Característi- } \\
\text { ca do Estudo }\end{array}$ & Achados sobre a Geração Y \\
\hline $\begin{array}{l}\text { Veloso et al } \\
(2008)\end{array}$ & $\begin{array}{l}\text { Nacional, } \\
\text { transversal, } \\
\text { quantitativo }\end{array}$ & $\begin{array}{l}\text { A geração Y está mais favorável às afirmativas do knowing-how e knowing- } \\
\text { whom, principalmente ligado a questões relacionadas a carreira, e menos } \\
\text { favorável às afirmativas do knowing-why do que a Geração X. }\end{array}$ \\
\hline $\begin{array}{l}\text { Vanconcelos } \\
\text { et al (2009) }\end{array}$ & $\begin{array}{l}\text { Nacional, } \\
\text { transversal, } \\
\text { quantitativo }\end{array}$ & $\begin{array}{l}\text { A âncora com maior destaque entre os jovens da Geração Y foi Estilo de } \\
\text { Vida, demonstrando a busca por oportunidades que permitam conciliar e } \\
\text { integrar necessidades pessoais, familiares e as exigências da carreira. }\end{array}$ \\
\hline $\begin{array}{l}\text { Cavazotte et } \\
\text { al (2010) }\end{array}$ & $\begin{array}{l}\text { Nacional, } \\
\text { transversal, } \\
\text { qualitativo }\end{array}$ & $\begin{array}{l}\text { A geração Y tem expectativas iguais a de outras gerações, tais como, } \\
\text { crescimento na empresa (mas com maior velocidade do que outras } \\
\text { gerações), estabilidade e bom salário. Dentre as expectativas exclusivas da } \\
\text { Geração Y, foram identificadas: desafios e dinamismo, prazer no trabalho, } \\
\text { flexibilidade, qualidade de vida, reconhecimento e feedback, bom } \\
\text { relacionamento com as pessoas, bom ambiente e o interesse em trabalhar em } \\
\text { uma organização socialmente responsável. }\end{array}$ \\
\hline $\begin{array}{l}\text { Silva et al } \\
(2011)\end{array}$ & $\begin{array}{l}\text { Nacional, } \\
\text { transversal, } \\
\text { quantitativo }\end{array}$ & $\begin{array}{l}\text { A geração Y apresentara proporção maior de respondentes no grupo das } \\
\text { novas carreiras. }\end{array}$ \\
\hline $\begin{array}{l}\text { Nogueira et } \\
\text { al (2011) }\end{array}$ & $\begin{array}{l}\text { Nacional, } \\
\text { transversal, } \\
\text { quantitativo }\end{array}$ & $\begin{array}{l}\text { Indivíduos da Geração Y apresentaram níveis mais baixos de } \\
\text { comprometimento organizacional do que os da geração X em diversas bases. }\end{array}$ \\
\hline $\begin{array}{l}\text { Vale et al } \\
(2011)\end{array}$ & $\begin{array}{l}\text { Nacional, } \\
\text { transversal, } \\
\text { quantitativo }\end{array}$ & $\begin{array}{l}\text { As diferenças geracionais não impactam nas bases de comprometimento dos } \\
\text { sujeitos. }\end{array}$ \\
\hline $\begin{array}{l}\text { Veloso et al } \\
\text { (2011) }\end{array}$ & $\begin{array}{l}\text { Nacional, } \\
\text { transversal, } \\
\text { quantitativo }\end{array}$ & $\begin{array}{l}\text { A percepção sobre a competência Knowing whom influencia mais a visão } \\
\text { dos Baby Boomers sobre crescimento profissional, do que as pessoas das } \\
\text { gerações X e Y e eles utilizam melhor a influência política nas organizações } \\
\text { do que as outras gerações. Por outro lado, as gerações X e Y, por serem mais } \\
\text { questionadoras, apresentam influência mais positiva da percepção de } \\
\text { Knowing why sobre sua percepção sobre crescimento profissional. }\end{array}$ \\
\hline $\begin{array}{l}\text { Cia de } \\
\text { Talentos } \\
(2012)\end{array}$ & $\begin{array}{l}\text { Nacional, } \\
\text { longitudinal, } \\
\text { quantitativo }\end{array}$ & $\begin{array}{l}\text { Os fatores que definem o sucesso para os jovens são relacionados com a } \\
\text { capacidade de aproveitar as oportunidades e de fazer o que gosta. Os } \\
\text { principais motivos da escolha das empresas dos sonhos estão relacionados à: } \\
\text { desenvolvimento profissional, desafios, boa imagem no mercado, bom } \\
\text { ambiente de trabalho e carreira internacional. Ao longo dos últimos cinco } \\
\text { anos essa sequência tem se alterado indicando uma tendência de valorização } \\
\text { de benefícios intangíveis e da busca da realização, desenvolvimento e bem- } \\
\text { estar no trabalho. }\end{array}$ \\
\hline $\begin{array}{l}\text { Chudzikows } \\
\text { ki et al } \\
(2012)\end{array}$ & $\begin{array}{l}\text { Internacional, } \\
\text { transversal, } \\
\text { qualitativo }\end{array}$ & $\begin{array}{l}\text { Geração Y é um grupo mais homogêneo quanto à importância da } \\
\text { autorrealização como um elemento principal do sucesso na carreira do que } \\
\text { as outras gerações. Países que sofreram grandes mudanças socioeconômicas } \\
\text { apresentaram maiores diferenças entre as respostas entre a antiga e nova } \\
\text { geração quanto ao sucesso na carreira. Transição de carreira dos jovens é } \\
\text { orientada e motivada mais pelos motivos intrínsecos. Ex.: desejo de fazer } \\
\text { algo novo, desenvolvimento. Membros mais jovens vivenciavam suas } \\
\text { carreiras de modo mais similar entre diferentes países do que os mais velhos }\end{array}$ \\
\hline
\end{tabular}

Indivíduos de diferentes gerações apresentam diferentes percepções, expectativas e atitudes quanto à carreira. Tanto a teoria de gerações quanto estudos sobre carreiras apontam que indivíduos da Geração Y tendem a ter atitudes mais modernas de carreira. No entanto, essa relação entre geração e carreira pode variar de acordo com o contexto nacional e de acordo com outras variáveis sócio-demográficas. 


\section{PROCEDIMENTOS METODOLÓGICOS}

O intuito desse capítulo é apresentar a metodologia utilizada para a condução da pesquisa tendo como base o objetivo principal e os objetivos específicos detalhados no capítulo 2.

Serão apresentados o delineamento da pesquisa, o modelo conceitual do estudo, as definições operacionais, a amostra, o instrumento de coleta de dados, o método de coleta de dados, os resultados do pré-teste realizado e as técnicas de tratamento e análise de dados.

\subsection{Delineamento da pesquisa}

Antes do início do esforço de pesquisa, faz-se necessário a definição do método. De acordo com Marconi e Lakatos (2003, p. 83), o método é “o conjunto das atividades sistemáticas e racionais que, com maior segurança e economia, permite alcançar o objetivo - conhecimentos válidos e verdadeiros -, traçando o caminho a ser seguido, detectando erros e auxiliando as decisões do cientista.".

Esse estudo é do tipo empírico-analítico, de acordo com a classificação de Martins (2007), pois se dedica a codificação dos aspectos mensuráveis da realidade social, utilizando técnicas de coleta, tratamento e análise de dados marcadamente quantitativas. Ele também pode ser identificado como descritivo, conforme classificação proposta por Vergara (2009), pois busca descrever as características de uma determinada população e estabelecer correlações entre variáveis.

A identificação do perfil de carreira de indivíduos da Geração Y é uma forma de mensuração da realidade social e entendimento das características desse grupo, buscando estabelecer relações entre a geração a qual ele pertence e suas atitudes de carreira.

Como decorrência do tipo de pesquisa e do posicionamento quantitativo da mesma, faz-se necessário o uso do método estatístico para análise dos resultados, buscando obter de um 
conjunto complexo de informações representações simples e constatar as relações entre as variáveis estudadas (MARCONI; LAKATOS, 2003).

Para o levantamento dos dados necessários para a análise estatística será utilizado um questionário, aplicando-se a técnica conhecida como survey que busca as informações necessárias “(...) junto às fontes primárias geralmente através de aplicação de questionários para grande quantidade de pessoas." (MARTINS, 2007, p. 36). Esse método é utilizado para o estudo das relações entre características de pessoas ou grupos, da forma como ocorrem em situações naturais (MARTINS; THEÓPHILO, 2009).

As perguntas que compõem uma survey devem cobrir quatro áreas fundamentais, conforme sugere Martins e Theóphilo (2009, p. 61): dados pessoais, dados sobre comportamento, dados relativos ao ambiente (circunstâncias em que os respondentes vivem) e dados sobre nível de informações, opiniões, atitudes, mensurações e expectativas. "Os levantamentos que objetivam o estudo conjunto desses dados, quando possível, são muito mais produtivos do que os que pretendem focar apenas um desses aspectos." (Ibid., p. 61). Aplicando-se a recomendação acima, será possível comparar resultados de subgrupos dentro da amostra estudada, analisando a relação entre os resultados de perfil de carreira e outras variáveis, tais como, renda, escolaridade, experiência profissional, etc.

\subsection{Modelo conceitual}

O quadro 15 foi inspirado na matriz de amarração de Mazzon (TELLES, 2001) e também no desenho proposto por Nakata (2009) em sua dissertação de mestrado e resume as informações metodológicas fornecidas até o momento pelo presente estudo. 
Quadro 15 - Desenho do estudo

\begin{tabular}{|c|c|}
\hline Questão de Pesquisa & $\begin{array}{l}\text { Quais são os perfis de carreira dos indivíduos da Geração Y no } \\
\text { Brasil? }\end{array}$ \\
\hline Fundamentação Teórica & $\begin{array}{l}\text { - Carreira sem fronteiras } \\
\text { - Carreira proteana } \\
\text { - Escalas de atitudes de carreira de Briscoe et al (2006), traduzida } \\
\text { e validada por Silva (2009) } \\
\text { - Perfil de carreira (BRISCOE; HALL, 2006) } \\
\text { - Geração Y }\end{array}$ \\
\hline Pontos de investigação & $\begin{array}{l}\text { Características demográficas dos respondentes } \\
\text { Autoavaliação quanto a suas atitudes de carreira }\end{array}$ \\
\hline Tipo & Empírica-analítica ou Descritiva \\
\hline Coleta de dados & Survey \\
\hline Análise dos dados & Estatística \\
\hline Resultado esperado & $\begin{array}{l}\text { - Validar as escalas de atitudes de carreira sem fronteiras e } \\
\text { proteana para a amostra estudada; } \\
\text { - Classificar os indivíduos da Geração Y conforme suas atitudes } \\
\text { de carreira; } \\
\text { - Investigar a influência das características demográficas e } \\
\text { profissionais nas atitudes de carreira; } \\
\text { - Investigar a influência das características demográficas e } \\
\text { profissionais nos perfis de carreira encontrados. }\end{array}$ \\
\hline $\begin{array}{l}\text { Apresentação do } \\
\text { resultado }\end{array}$ & $\begin{array}{l}\text {-Descritivo } \\
\text {-Tabelas } \\
\text {-Quadros } \\
\text {-Gráficos }\end{array}$ \\
\hline
\end{tabular}

Fonte: adaptado de TELLES, 2001; NAKATA, 2009

Para aprofundamento do modelo conceitual, a ilustração 4 mostra o problema de pesquisa proposto dentro da estrutura proposta pelo Paradigma de Rubinstein. 


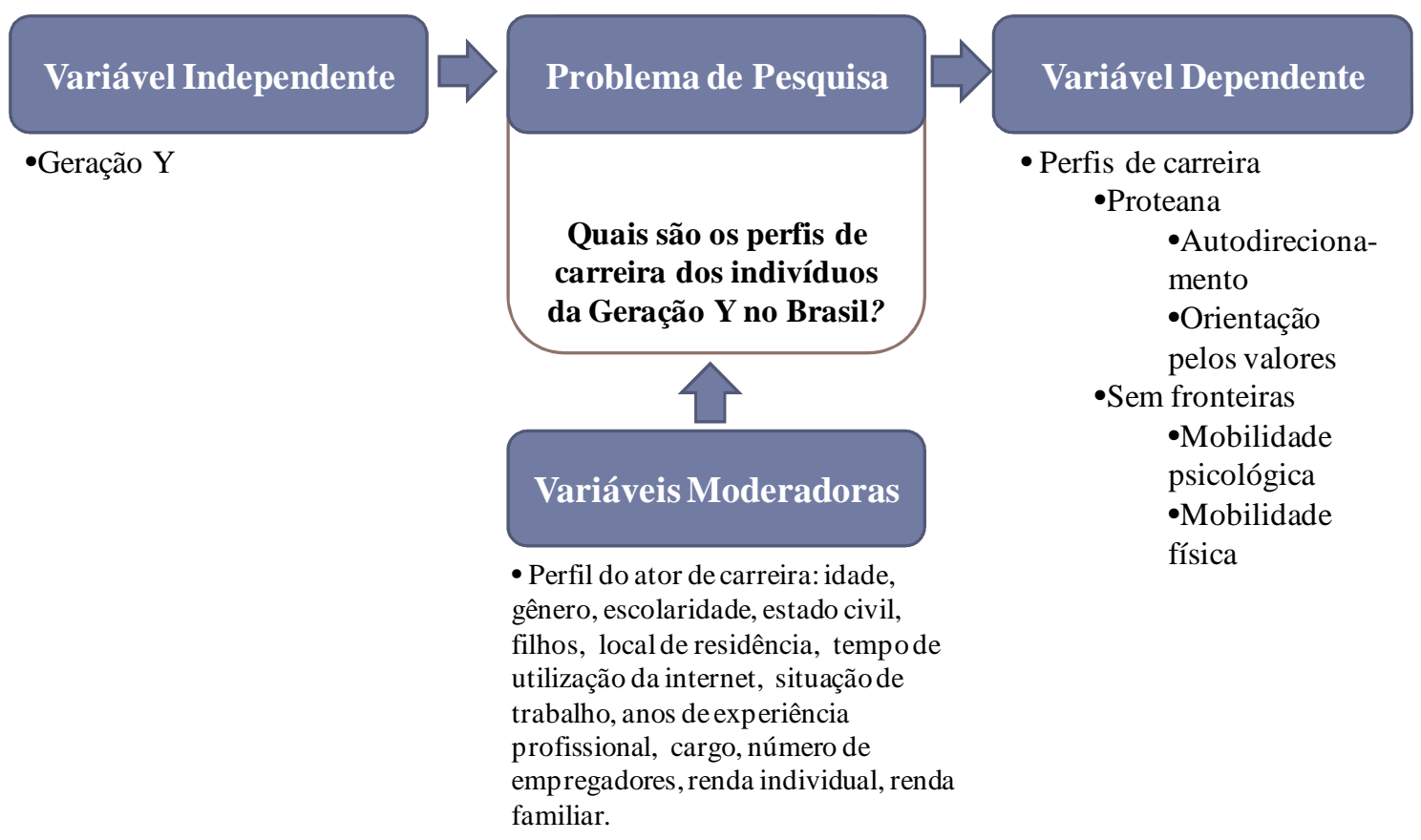

Ilustração 4 - Paradigma de Rubinstein

A variável independente influencia outra variável e é fator determinante ou condição para determinado resultado, efeito ou consequência (MARCONI; LAKATOS, 2003). Logo, a Geração Y é a variável independente principal nesse estudo, pois se busca o entendimento de como ser membro de uma determinada geração afeta as atitudes de carreira de um indivíduo.

As variáveis dependentes são fatores a serem explicados ou descobertos, em virtude de serem influenciados ou determinados pela variável independente (ibid.). Logo, as atitudes de carreira apresentadas pelos indivíduos da Geração Y são variáveis dependentes.

As variáveis moderadoras são condições dadas como constantes no estudo, no caso, o perfil demográfico e profissional da amostra estudada, que pode influenciar as variáveis dependentes, mas não pode ser manipulado.

\subsection{Definições operacionais}

Como mencionado no capítulo 2, a questão de pesquisa proposta é:

Quais são os perfis de carreira dos indivíduos da Geracão Y no Brasil? 
Para esclarecimento da questão de pesquisa faz-se necessário estabelecer as seguintes definições operacionais:

a) perfis de carreira: categorias nas quais os atores de carreira podem ser classificados a partir do grau de presença das duas dimensões de carreira proteana (autodirecionamento de carreira e orientação pelos valores) e das duas dimensões de carreira sem fronteiras (mobilidade física e mobilidade psicológica). Essas categorias serão desenvolvidas com base nos resultados da própria amostra a partir da análise de agrupamentos e também tendo como referencial conceitual o modelo de perfis de carreira propostos por Briscoe e Hall (2006).

b) indivíduos da Geração Y no Brasil: indivíduos da Geração Y, nascidos entre 1982 e 1994 com experiência profissional mínima de 1 ano. Essa limitação de idade e tempo de experiência profissional busca selecionar indivíduos que já tenham uma vivência profissional mínima que os ampare no desenvolvimento de expectativas e percepções em relação a sua própria carreira e permitam que eles ofereçam respostas consistentes às questões propostas.

\subsection{Amostra}

Com o intuito de buscar uma amostra dos jovens da Geração Y no Brasil foi firmada uma parceria com a Nextview, empresa de pesquisa sobre tendências em Gestão e Desenvolvimento de Pessoas, responsável por uma das maiores pesquisas nacionais envolvendo jovens. A Nextview enviou o questionário para jovens da Geração Y que fazem parte do banco de dados da Cia de Talentos, empresa que, assim como a Nextview, faz parte do Grupo DMRH.

A Cia de Talentos construiu seu banco de dados através da gestão de processos seletivos para diversas empresas clientes e hoje conta com mais de 400.000 pessoas cadastradas. O link de acesso ao questionário foi enviado através de um e-mail para um público de 40.000 jovens que fazem parte do banco de dados da Cia de Talentos e que haviam se prontificado a participar de pesquisas. Além disso, a pesquisa foi divulgada no site de internet ClickCarreira 
(vide anexo A).

Logo, a amostra é composta por jovens da Geração Y, nascidos entre 1982 e 1994, que possuem pelo menos um ano de experiência profissional e que se dispuseram a responder a pesquisa. A amostra é composta por pessoas que fazem parte do banco de dados da Cia de Talentos, consequentemente estiveram ou estão em busca de posições de trabalho.

A amostra utilizada nesse estudo é não-probabilística e intencional (MARTINS, 2007), pois há uma escolha deliberada dos elementos da amostra, baseada no acesso aos indivíduos estudados e na disponibilidade dos mesmos em responder a pesquisa.

\subsection{Instrumento de coleta de dados}

Dada a questão de pesquisa, a natureza descritiva e o uso da técnica de survey, far-se-á uso de um questionário para coleta de dados. Um questionário é “(...) um conjunto ordenado e consistente de perguntas a respeito de variáveis e situações que se deseja medir ou descrever." (MARTINS; THEÓPHILO, 2009, p. 93).

O instrumento de coleta tem como base as escalas de atitudes de carreira proteana e sem fronteiras desenvolvida por Briscoe et al (2006), traduzidas para o Português e validadas no Brasil por Silva (2009). A partir do trabalho de Silva (2009) foram feitos pequenos ajustes em palavras ou ordem das palavras para melhorar o entendimento das questões por parte dos respondentes.

A comparação entre esses 3 questionários, o elaborado por Briscoe et al (2006), o questionário traduzido e validado por Silva (2009) e o utilizado nessa dissertação está organizada no apêndice 1 .

Os cinco pontos da escala de resposta de cada questão também tiveram suas descrições adaptadas para esse estudo e a comparação entre essas descrições utilizadas originalmente por Briscoe et al (2006), Silva (2009) e a utilizada nessa dissertação consta no apêndice 2.

O questionário foi dividido em 3 partes: 
Parte 1 - Atitudes de carreira proteana: questões que avaliam o grau de concordância dos respondentes em relação a atitudes associadas às duas dimensões da carreira proteana (autodirecionamento de carreira e orientação pelos valores). A atitude está relacionada com o comportamento do sujeito em relação à situação que lhe é exposta e é indicadora de conduta, ou seja, gera uma pré-disposição a um determinado comportamento. As atitudes podem ser positivas ou negativas, quando é avaliada a direção, e alta ou baixa, quando é avaliada a intensidade (MARTINS; THEÓPHILO, 2009). Para tanto, as questões serão compostas de afirmativas para que o sujeito externe sua reação, escolhendo um dos cinco pontos de uma escala e manifestando o grau de concordância com as afirmações apresentadas, ou seja, dentro de uma escala Likert.

O quadro 16 apresenta as questões aplicadas nesta pesquisa.

Quadro 16 - Questões da escala de atitude da carreira proteana

\begin{tabular}{|c|c|}
\hline Dimensão & Questão \\
\hline Autodirecionamento & $\begin{array}{l}\text { 1. Quando oportunidades de desenvolvimento não me foram oferecidas por minha } \\
\text { empresa, busquei-as por mim mesmo }\end{array}$ \\
\hline Autodirecionamento & 2. Sou responsável por meu sucesso ou fracasso em minha carreira \\
\hline Autodirecionamento & 3. De um modo geral, tenho uma carreira bastante independente e dirigida por mim \\
\hline Autodirecionamento & $\begin{array}{l}\text { 4. Liberdade para escolher minha própria trajetória de carreira é um dos meus } \\
\text { valores mais importantes }\end{array}$ \\
\hline Autodirecionamento & 5. Estou no comando de minha própria carreira \\
\hline Autodirecionamento & 6. No final das contas, dependo de mim mesmo para avançar em minha carreira \\
\hline Autodirecionamento & 7. No que diz respeito à minha carreira, quem toma as decisões sou eu \\
\hline Autodirecionamento & $\begin{array}{l}\text { 8. Em minhas experiências passadas, confiei mais em mim mesmo do que em outras } \\
\text { pessoas para encontrar um novo emprego, quando necessário }\end{array}$ \\
\hline $\begin{array}{l}\text { Orientação pelos } \\
\text { valores }\end{array}$ & $\begin{array}{l}\text { 9. Eu conduzo minha própria carreira, baseado(a) em minhas prioridades pessoais e } \\
\text { não nas prioridades de meu empregador }\end{array}$ \\
\hline $\begin{array}{l}\text { Orientação pelos } \\
\text { valores }\end{array}$ & $\begin{array}{l}\text { 10. Não é muito importante para mim a forma com que as pessoas avaliam as } \\
\text { escolhas que eu faço em minha carreira }\end{array}$ \\
\hline $\begin{array}{l}\text { Orientação pelos } \\
\text { valores }\end{array}$ & $\begin{array}{l}\text { 11. O que mais importa para mim é como eu me sinto em relação a meu sucesso na } \\
\text { carreira e não como outras pessoas se sentem a respeito disso }\end{array}$ \\
\hline $\begin{array}{l}\text { Orientação pelos } \\
\text { valores }\end{array}$ & $\begin{array}{l}\text { 12. Sigo a minha própria consciência se a minha empresa solicitar que eu faça algo } \\
\text { que seja contra os meus valores }\end{array}$ \\
\hline $\begin{array}{l}\text { Orientação pelos } \\
\text { valores }\end{array}$ & $\begin{array}{l}\text { 13. O que eu acho que está certo em minha carreira é mais importante para mim do } \\
\text { que o que minha empresa acha }\end{array}$ \\
\hline $\begin{array}{l}\text { Orientação pelos } \\
\text { valores }\end{array}$ & $\begin{array}{l}\text { 14. Em minhas experiências passadas, eu segui meus próprios valores mesmo } \\
\text { quando a empresa me pediu para fazer algo com o qual eu não concordava }\end{array}$ \\
\hline
\end{tabular}

Fonte: adaptado de SILVA, 2009; BRISCOE et al, 2006

Parte 2 - Atitudes de carreira sem fronteiras: questões que avaliam a concordância dos respondentes a atitudes relacionadas às duas dimensões da carreira sem fronteiras (mobilidade psicológica e mobilidade física), conforme apresentado no quadro 17. 
Quadro 17 - Questões da escala de atitude da carreira sem fronteiras

\begin{tabular}{|c|c|}
\hline Dimensão & Questão \\
\hline Mobilidade psicológica & 15. Procuro tarefas que me permitam aprender algo novo \\
\hline Mobilidade psicológica & 16. Gostaria de trabalhar em projetos com pessoas de várias organizações \\
\hline Mobilidade psicológica & 17. Gosto de tarefas que requeiram que eu trabalhe fora da organização \\
\hline Mobilidade psicológica & $\begin{array}{l}\text { 18. Gosto de tarefas em meu trabalho que requeiram que eu trabalhe além do } \\
\text { meu próprio departamento }\end{array}$ \\
\hline Mobilidade psicológica & 19. Gosto de trabalhar com pessoas fora da minha organização \\
\hline Mobilidade psicológica & $\begin{array}{l}\text { 20. Gosto de trabalhos que requeiram que eu interaja com pessoas de várias } \\
\text { organizações diferentes }\end{array}$ \\
\hline Mobilidade psicológica & $\begin{array}{l}\text { 21. No passado, busquei oportunidades que me permitissem trabalhar fora da } \\
\text { organização }\end{array}$ \\
\hline Mobilidade psicológica & 22. Sinto-me motivado quando enfrento experiências e situações novas \\
\hline Mobilidade física & $\begin{array}{l}\text { 23. Gosto da previsibilidade decorrente de se trabalhar continuamente para a } \\
\text { mesma organização }\end{array}$ \\
\hline Mobilidade física & $\begin{array}{l}\text { 24. Eu me sentiria bastante perdido se não pudesse trabalhar para a minha atual } \\
\text { organização }\end{array}$ \\
\hline Mobilidade física & $\begin{array}{l}\text { 25. Prefiro permanecer em uma empresa com a qual eu esteja familiarizado do } \\
\text { que procurar por outro emprego em outro lugar }\end{array}$ \\
\hline Mobilidade física & $\begin{array}{l}\text { 26. Se minha empresa proporcionasse emprego vitalício, eu nunca iria querer } \\
\text { procurar trabalho em outras organizações }\end{array}$ \\
\hline Mobilidade física & 27. O meu ideal de carreira seria trabalhar apenas para uma única organização \\
\hline
\end{tabular}

Fonte: adaptado de SILVA, 2009; BRISCOE et al, 2006

Parte 3 - Perfil demográfico: busca compreender as características dos respondentes e permitirá a análise da associação entre essas características e a atitude/perfil de carreira de um determinado indivíduo. Essas variáveis demográficas foram definidas a partir da análise da literatura sobre Gerações e Carreiras e a partir da identificação das questões que podem impactar os perfis de carreira de um indivíduo (SEGERS et al, 2008; SILVA et al, 2011; SCALABRIN, 2008; SULLIVAN; ARTHUR, 2006). O quadro 18 detalha essas questões.

\section{Quadro 18 - Questões demográficas}

\begin{tabular}{|c|c|c|c|c|}
\hline $\begin{array}{c}\text { Questões } \\
\text { Demográficas }\end{array}$ & $\begin{array}{c}\text { Tipo de } \\
\text { pergunta }\end{array}$ & $\begin{array}{c}\text { Valores que as variáveis } \\
\text { podem assumir }\end{array}$ & $\begin{array}{c}\text { Tipo de } \\
\text { variável }\end{array}$ & \multicolumn{1}{|c|}{ Porque incluir essa variável } \\
\hline $\begin{array}{c}\text { Ano de } \\
\text { nascimento }\end{array}$ & $\begin{array}{c}\text { Múltipla } \\
\text { escolha }\end{array}$ & Entre 1920 e 2000 & $\begin{array}{l}\text { - Garantir que o respondente seja } \\
\text { da geração Y. A idade impacta a } \\
\text { atitude de carreira (SEGERS } \text { et al, } \\
\text { 2008). A geração pode impactar a } \\
\text { atitude de carreira (SULLIVAN; } \\
\text { ARTHUR, 2006) }\end{array}$ \\
\hline Gênero & $\begin{array}{c}\text { Dicotômi } \\
\text { ca }\end{array}$ & $\begin{array}{l}\text { Masculino } \\
\text { Feminino }\end{array}$ & Nominal & $\begin{array}{l}\text { - Caracterizar o respondente, } \\
\text { sendo que o gênero é uma }\end{array}$ \\
\hline
\end{tabular}




\begin{tabular}{|c|c|c|c|c|}
\hline $\begin{array}{c}\text { Questões } \\
\text { Demográficas }\end{array}$ & $\begin{array}{c}\text { Tipo de } \\
\text { pergunta }\end{array}$ & $\begin{array}{c}\text { Valores que as variáveis } \\
\text { podem assumir }\end{array}$ & $\begin{array}{c}\text { Tipo de } \\
\text { variável }\end{array}$ & Porque incluir essa variável \\
\hline & & & & $\begin{array}{l}\text { variável que pode impactar na } \\
\text { atitude de carreira (SEGERS et al, } \\
\text { 2008; SILVA et al, 2011; } \\
\text { SCALABRIN, 2008; } \\
\text { SULLIVAN; ARTHUR, 2006) }\end{array}$ \\
\hline Escolaridade & $\begin{array}{l}\text { Múltipla } \\
\text { escolha }\end{array}$ & $\begin{array}{l}\text { Ensino fundamental } \\
\text { Ensino médio } \\
\text { Ensino superior } \\
\text { Pós-graduação }\end{array}$ & Nominal & $\begin{array}{l}\text { - Caracterizar o respondente, } \\
\text { sendo que escolaridade é uma } \\
\text { variável que pode impactar na } \\
\text { atitude de carreira (BRISCOE et } \\
a l, 2006 ; \text { SEGERS et al, 2008) }\end{array}$ \\
\hline Estado Civil & $\begin{array}{l}\text { Múltipla } \\
\text { escolha }\end{array}$ & $\begin{array}{l}\text { Solteiro } \\
\text { Casado / União Estável } \\
\text { Divorciado / Separado }\end{array}$ & Nominal & $\begin{array}{l}\text { - Caracterizar o respondente, } \\
\text { sendo que o estado civil é uma } \\
\text { variável que pode impactar na } \\
\text { atitude de carreira (SCALABRIN, } \\
\text { 2008) }\end{array}$ \\
\hline Tem filhos? & $\begin{array}{l}\text { Múltipla } \\
\text { escolha }\end{array}$ & $\begin{array}{l}\text { Não tenho filhos } \\
\text { Sim, tenho } 1 \\
\text { Sim, tenho } 2 \\
\text { Sim, tenho } 3 \text { ou mais }\end{array}$ & Nominal & $\begin{array}{l}\text { - Caracterizar o respondente, } \\
\text { sendo que o número de filhos é } \\
\text { uma variável que pode impactar } \\
\text { na atitude de carreira } \\
\text { (SCALABRIN, 2008) }\end{array}$ \\
\hline $\begin{array}{l}\text { Estado em } \\
\text { que reside }\end{array}$ & $\begin{array}{l}\text { Múltipla } \\
\text { escolha }\end{array}$ & (lista de estados) & Nominal & $\begin{array}{l}\text { - Caracterizar o respondente, } \\
\text { sendo que o local de residência } \\
\text { pode impactar na atitude de } \\
\text { carreira (RIBEIRO et al, 2009) }\end{array}$ \\
\hline $\begin{array}{l}\text { Cidade em } \\
\text { que reside }\end{array}$ & Aberta & (texto livre) & Nominal & $\begin{array}{l}\text { - Caracterizar o respondente, } \\
\text { sendo que o local de residência } \\
\text { pode impactar na atitude de } \\
\text { carreira (RIBEIRO } \text { et al, 2009) }\end{array}$ \\
\hline $\begin{array}{l}\text { Tempo médio } \\
\text { diário de } \\
\text { utilização da } \\
\text { internet }\end{array}$ & $\begin{array}{l}\text { Múltipla } \\
\text { escolha }\end{array}$ & $\begin{array}{l}\text { Menos de } 1 \text { hora } \\
\text { De } 1 \text { a } 2 \text { horas } \\
\text { De } 2 \text { a } 4 \text { horas } \\
\text { De } 4 \text { a } 8 \text { horas } \\
\text { Mais de } 8 \text { horas }\end{array}$ & Intervalar & $\begin{array}{l}\text { - Caracterizar respondente quanto } \\
\text { a uma das características mais } \\
\text { descritas da Geração Y, o acesso } \\
\text { frequente a internet }\end{array}$ \\
\hline $\begin{array}{c}\text { Está } \\
\text { trabalhando } \\
\text { atualmente? }\end{array}$ & $\begin{array}{l}\text { Dicotômi } \\
\text { ca }\end{array}$ & $\begin{array}{l}\text { Sim } \\
\text { Não }\end{array}$ & Nominal & - Caracterizar o respondente \\
\hline $\begin{array}{l}\text { Anos de } \\
\text { experiência } \\
\text { profissional } \\
\text { (incluindo } \\
\text { estágio) }\end{array}$ & $\begin{array}{l}\text { Múltipla } \\
\text { escolha }\end{array}$ & $\begin{array}{l}\text { Não tenho experiência } \\
\text { profissional } \\
\text { Menos de } 1 \text { ano } \\
\text { Entre } 1 \text { e } 2 \text { anos } \\
\text { Entre } 2 \text { e } 3 \text { anos } \\
\text { Entre } 3 \text { e } 5 \text { anos } \\
\text { Entre } 5 \text { e } 7 \text { anos } \\
\text { Mais de } 7 \text { anos }\end{array}$ & Intervalar & $\begin{array}{l}\text { - Caracterizar o respondente, } \\
\text { sendo que indivíduos de maior } \\
\text { experiência profissional têm } \\
\text { identidade profissional } \\
\text { consolidada. }\end{array}$ \\
\hline Cargo & $\begin{array}{l}\text { Múltipla } \\
\text { escolha }\end{array}$ & $\begin{array}{l}\text { - Diretor / Gerente } \\
\text { - Coordenador / Supervisor / } \\
\text { Consultor } \\
\text { - Analista / Auxiliar / } \\
\text { Assistente } \\
\text { - Trainee } \\
\text { - Estagiário } \\
\text { - Outro (especifique) }\end{array}$ & Nominal & $\begin{array}{l}\text { - Caracterizar o respondente, } \\
\text { sendo que a experiência em } \\
\text { posição executiva é uma variável } \\
\text { que pode impactar na atitude de } \\
\text { carreira (SEGERS et al, 2008) }\end{array}$ \\
\hline $\begin{array}{l}\text { Número de } \\
\text { empregado- }\end{array}$ & $\begin{array}{l}\text { Múltipla } \\
\text { escolha }\end{array}$ & Entre 0 e 15 & Ordinal & - Analisar mobilidade física \\
\hline
\end{tabular}




\begin{tabular}{|c|c|c|c|c|}
\hline $\begin{array}{c}\text { Questões } \\
\text { Demográficas }\end{array}$ & $\begin{array}{c}\text { Tipo de } \\
\text { pergunta }\end{array}$ & $\begin{array}{c}\text { Valores que as variáveis } \\
\text { podem assumir }\end{array}$ & $\begin{array}{c}\text { Tipo de } \\
\text { variável }\end{array}$ & Porque incluir essa variável \\
\hline \multicolumn{5}{|l|}{$\begin{array}{l}\text { res para os } \\
\text { quais já } \\
\text { trabalhou nos } \\
\text { últimos } 5 \\
\text { anos }\end{array}$} \\
\hline $\begin{array}{c}\text { Renda } \\
\text { individual } \\
\text { média mensal }\end{array}$ & $\begin{array}{l}\text { Múltipla } \\
\text { escolha }\end{array}$ & $\begin{array}{l}\text { Sem rendimento } \\
\text { Até } \mathrm{R} \$ 622,00 \\
\text { Entre } \mathrm{R} \$ 622,00 \text { e } \mathrm{R} \$ \\
1.244,00 \\
\text { Entre } \mathrm{R} \$ 1.244,00 \text { e } \mathrm{R} \$ \\
1.866,00 \\
\text { Entre } \mathrm{R} \$ 1.866,00 \text { e } \mathrm{R} \$ \\
3.110,00 \\
\text { Entre } \mathrm{R} \$ 3.110,00 \text { e } \mathrm{R} \$ \\
6.220,00 \\
\text { Mais de } \mathrm{R} \$ 6.220,00\end{array}$ & Intervalar & $\begin{array}{l}\text { - Caracterizar o respondente. A } \\
\text { classe social é parte na definição } \\
\text { de geração (MANNHEIM, 1993) } \\
\text { e pode impactar na atitude de } \\
\text { carreira (SULLIVAN; ARTHUR, } \\
\text { 2006). Baseado em números de } \\
\text { salários mínimos (1 salário } \\
\text { mínimo = R\$ 622,00). Faixas } \\
\text { respeitam o critério utilizado pelo } \\
\text { IBGE no Censo 2010. }\end{array}$ \\
\hline $\begin{array}{c}\text { Renda } \\
\text { familiar } \\
\text { média mensal }\end{array}$ & $\begin{array}{l}\text { Múltipla } \\
\text { escolha }\end{array}$ & $\begin{array}{l}\text { Até } \mathrm{R} \$ 1.224,00 \\
\text { Entre } \mathrm{R} \$ 1.224,00 \text { e } \mathrm{R} \$ \\
2.488,00 \\
\text { Entre } \mathrm{R} \$ 2.488,00 \text { e } \mathrm{R} \$ \\
6.220,00 \\
\text { Entre } \mathrm{R} \$ 6.220,00 \text { e } \mathrm{R} \$ \\
12.440,00 \\
\text { Mais de } \mathrm{R} \$ 12.440,00\end{array}$ & Intervalar & $\begin{array}{l}\text { - Caracterizar o respondente. A } \\
\text { classe social é parte da definição } \\
\text { de geração (MANNHEIM, 1993) } \\
\text { e pode impactar na atitude de } \\
\text { carreira (SULLIVAN; ARTHUR, } \\
\text { 2006). Baseado em números de } \\
\text { salários mínimos (1 salário } \\
\text { mínimo = R\$ 622,00). }\end{array}$ \\
\hline
\end{tabular}

Apresentado o instrumento de coleta, a próxima subseção definirá os procedimentos de coleta de dados utilizados.

\subsection{Coleta de dados}

Os dados foram coletados através de um questionário eletrônico, disponível em uma página na internet, utilizando-se o software SurveyMonkey. O endereço eletrônico para acessar o questionário foi enviado por correio eletrônico aos potenciais respondentes pela Cia de Talentos, detentora da lista de e-mails. O texto enviado está descrito no apêndice 3. O questionário eletrônico pode ser visualizado no apêndice 4. Além disso, a pesquisa também foi divulgada na internet através do site ClickCarreira (vide anexo A).

Para realização de um questionário eletrônico, os mesmos cuidados com o uso do questionário em papel devem ser tomados, mas esse método exige a verificação de certas particularidades (MARTINS; THEÓPHILO, 2009; VASCONCELLOS; GUEDES, 2007). Devem-se observar as vantagens e buscar formas de minimizar as desvantagens apresentadas no quadro 19 . 
Quadro 19 - Vantagens e desvantagens do questionário eletrônico

\begin{tabular}{|c|c|}
\hline Vantagens & Desvantagens \\
\hline $\begin{array}{l}\text { - } \text { Menor custo } \\
\text { Maior velocidade na } \\
\text { aplicação, controle e follow- } \\
\text { up das respostas e na } \\
\text { tabulação de resultados } \\
\text { - } \text { Possibilidade de distribuição a } \\
\text { grande número de } \\
\text { respondentes } \\
\text { - Exigência de resposta } \\
\text { completa. } \\
\text { Atratividade, facilidade e } \\
\text { agilidade para o respondente }\end{array}$ & $\begin{array}{l}\text { - Limita-se a potenciais respondentes que tenham acesso à internet e } \\
\text { conhecimento técnico de informática } \\
\text { - Baixa confiabilidade nos dados, uma vez que muitos respondentes } \\
\text { podem falsificar informações demográficas e responder mais de uma } \\
\text { vez. } \\
\text { - Amostra representativa da população e viés dos respondentes terem, } \\
\text { com relação à média da população, maior nível de escolaridade e } \\
\text { maior renda } \\
\text { - Respondentes podem considerar o recebimento da mensagem de e- } \\
\text { mail não desejada como uma invasão de privacidade ou "lixo } \\
\text { eletrônico" } \\
\text { - Baixo índice de resposta, menores que todos os outros métodos de } \\
\text { aplicação de questionário; } \\
\text { Erros na coleta dos dados através de questionários autopreenchidos } \\
\text { surgem do lado do respondente (falta de motivação, problemas de } \\
\text { compreensão, distorção deliberada etc.) ou do instrumento em si (texto } \\
\text { de difícil entendimento, desenho inadequado, falhas técnicas etc.). }\end{array}$ \\
\hline
\end{tabular}

Fonte: adaptado de MARTINS; THEÓPHILO, 2009; VASCONCELLOS; GUEDES, 2007

Considerando que o público-alvo da pesquisa são indivíduos da Geração Y, espera-se um alto uso e facilidade de acesso a internet pelos potenciais respondentes. Além disso, a lista de $e$ mails utilizada é atual e ativa, já que é a forma de contato para a gestão de processos seletivos, reduzindo algumas das desvantagens desse instrumento. Todos os cuidados com formatação, entendimento das questões e aspectos técnicos foram tomados, inclusive com a realização do pré-teste que avaliou e refinou esses quesitos.

O e-mail que foi enviado ao público alvo pode ser consultado no apêndice 3. Nesse documento foi fornecido a explicação da pesquisa, a identificação da pesquisadora e da instituição e o tempo necessário para a resposta. Além disso, o e-mail também oferece um relatório chamado "perfil de carreira", que consiste no resultado do tipo de perfil que o respondente individual foi classificado no final da pesquisa, indicando sugestões para desenvolvimento da carreira. Esse relatório foi oferecido como forma de estímulo à participação e à resposta sincera e será enviado após a finalização da pesquisa.

A coleta de dados foi realizada de 8 de março à 14 de maio de 2012 .

O software SurveyMonkey gerou um banco de dados com todas as respostas coletadas que foi utilizado como base para a análise dos dados. 


\subsection{Pré-teste}

O questionário foi submetido a um pré-teste antes do envio aos respondentes com o objetivo de identificar possíveis falhas, inconsistências, ambiguidades, linguagem inadequada, etc. O objetivo do pré-teste é o “(...) aprimoramento da confiabilidade e validade, ou seja, garantias de que o instrumento se ajuste totalmente a finalidade da pesquisa (...)" (MARTINS; THEÓPHILO, 2009).

O e-mail convite e o link para o modelo de questionário inicial foi enviado por e-mail para 11 indivíduos da Geração Y que fazem parte do grupo de contatos da pesquisadora no dia 7 de fevereiro de 2012. Foi solicitado o preenchimento do questionário e posterior feedback por email sobre os seguintes aspectos: clareza do e-mail, atratividade para responder a pesquisa, acesso e navegação na página eletrônica do questionário, clareza das perguntas e eventuais dificuldades ou problemas técnicos.

Nove pessoas $(82 \%)$ responderam a pesquisa e forneceram seus feedbacks por e-mail, quantidade adequada para a validação do instrumento, conforme Martins e Theóphilo (2009). Os feedbacks foram positivos destacando a facilidade de acesso e navegação e rapidez ao preencher o questionário. Foram utilizados em média 10 minutos no processo. Não foram relatados problemas técnicos ou dificuldades no acesso ou ao responder a pesquisa. $\mathrm{O}$ principal ponto de melhoria apontado no pré-teste foi em relação ao e-mail convite, mostrando a necessidade de um convite mais curto e informal. Alguns respondentes do préteste também forneceram sugestões para deixar mais claras as perguntas demográficas. Todas as sugestões e recomendações foram acatadas e resultaram no e-mail convite (apêndice 3) e no perfil demográfico utilizados.

O questionário foi considerado de linguagem clara, mas alguns respondentes apontaram a semelhança entre algumas perguntas. Considerando o uso de uma escala já validada, optou-se por manter o questionário da forma que estava. 


\subsection{Tratamento e análise dos dados}

Considerando que essa é uma pesquisa quantitativa, a base para análise dos resultados será a estatística, especificamente, a análise multivariada, tendo em vista que as variáveis estudadas são aleatórias e inter-relacionadas e o objetivo é medir, explicar e prever o grau de relação entre variáveis estatísticas (HAIR et al, 2009). Os dados coletados pelo SurveyMonkey foram tratados e analisados com o uso dos softwares Excel e Statistical Package for the Social Sciences v. 20 (SPSS).

Foram obtidas respostas de 3.056 participantes. A partir dessa base inicial, iniciou-se o tratamento da base de dados, identificando-se os outliers. Foram eliminados os casos descritos a seguir:

- 45 respondentes com respostas e e-mails duplicados. Foi mantida apenas uma resposta relativa a cada e-mail;

- 11 respondentes com respostas diferentes e e-mails duplicados. Foi considerada somente a última resposta, baseada na data de acesso, de cada participante, identificado pelo seu email;

- 6 respondentes que concentraram suas respostas em um único ponto da escala;

- 330 respondentes que nasceram antes de 1982, ou seja, que não pertencem a geração Y ou que nasceram no primeiro ano dessa geração. Optou-se por excluir os jovens nascidos em 1981 por esse ano ser o divisor sugerido por Amaral (2004).

- 32 respondentes que nasceram após 1994. Apesar de conceitualmente as pessoas nascidas após 1994 pertencerem a Geração Y, elas atualmente têm menos de 18 anos de idade e, consequentemente, possuem experiência limitada para responder as perguntas que indagam sobre decisões e experiências passadas em relação a sua vida profissional;

- 256 respondentes que tem menos de um ano de experiência profissional, pois as questões propostas indagam sobre experiências passadas e para avaliação da atitude de carreira é importante que exista uma experiência profissional mínima, estando ao menos no início da trajetória profissional.

Após a limpeza descrita acima, a base final de dados totalizou 2.376 respondentes. Todos responderam todas as perguntas da parte 1 e 2 do questionário. 
A confiabilidade de um instrumento de medição se refere ao grau em que sua repetida aplicação em uma mesma amostra gera resultados iguais. $\mathrm{O}$ instrumento apresentado nesse estudo teve sua confiabilidade avaliada pelo coeficiente alfa de Cronbach (MARTINS; THEÓPHILO, 2009).

A validade do instrumento é total, na medida em que utiliza um instrumento já validado e testado em pesquisas americanas e em uma pesquisa Brasileira. No entanto, conforme descrito no primeiro objetivo específico, a validade foi verificada com o uso das técnicas estatísticas de Análise Fatorial Exploratória (AFE) e Análise Fatorial Confirmatória (AFC).

Para a classificação dos indivíduos da Geração Y conforme suas atitudes de carreira foram realizadas análises de agrupamentos. A partir dessa técnica foram identificados os grupos que foram comparados com os perfis de carreira de Briscoe et al (2006).

Finalmente, foi investigada a influência das características demográficas e profissionais nas atitudes de carreira e nos perfis de carreira. A técnica estatística utilizada para essas análises foi o Qui-quadrado.

As técnicas estatísticas utilizadas para atender os objetivos de pesquisa estão listadas no quadro 20 e serão descritas em detalhes a seguir.

\section{Quadro 20 - Técnicas estatísticas utilizadas neste estudo}

\begin{tabular}{|l|l|}
\hline \multicolumn{1}{|c|}{ Objetivo Específico } & \multicolumn{1}{|c|}{ Técnica Estatística } \\
\hline $\begin{array}{l}\text { Validar das escalas de atitudes de carreira sem } \\
\text { fronteiras e proteana para a presente amostra }\end{array}$ & $\begin{array}{l}\text { Análise Fatorial Exploratória } \\
\text { Análise Fatorial Confirmatória }\end{array}$ \\
\hline $\begin{array}{l}\text { Classificar os indivíduos da Geração Y conforme } \\
\text { suas atitudes de carreira }\end{array}$ & Análise de Agrupamentos \\
\hline $\begin{array}{l}\text { Investigar a influência das características } \\
\text { demográficas e profissionais nas atitudes de carreira e } \\
\text { nos perfis de carreira encontrados }\end{array}$ & Qui-quadrado \\
\hline
\end{tabular}

\subsubsection{Análise Fatorial Exploratória e Confirmatória}

A validade das escalas serão testadas por dois métodos: pela Análise Fatorial Exploratória (AFE) e Análise Fatorial Confirmatória (AFC). 
A AFE, que inclui a Análise de Componentes Principais, é uma abordagem estatística que pode ser usada para analisar inter-relações entre um grande número de variáveis e explicar essas variáveis em termos de suas dimensões inerentes comuns. O objetivo é encontrar um meio de condensar a informação contida em várias variáveis originais, no caso dessa pesquisa, as questões, em um conjunto menor de variáveis estatísticas, nesse caso, as dimensões das teorias de carreira (HAIR et al, 2009).

A função da AFC é testar e potencialmente confirmar uma teoria. É uma maneira de testar o quão bem as variáveis medidas representam um número menor de constructos, requerendo que o pesquisador especifique quais variáveis são associadas com cada constructo, e então as cargas são estimadas somente onde variáveis são associadas com constructos. Pode ser usada para confirmar a mensuração desenvolvida usando-se a AFE.

A AFC difere da AFE, pois essa última, como diz o nome, tem uma função exploratória, já que não exige essa pré-definição e permite que o método e os dados definam a natureza das relações, guiados pelos resultados empíricos.

A AFC utiliza a Modelagem de Equações Estruturais (MEE) para especificação do modelo que deverá ser confirmado. A MEE é uma família de modelos estatísticos que buscam explicar as relações entre múltiplas variáveis, descrevendo todas as relações entre constructos envolvidos na análise, logo a análise deve ser ditada por uma forte base teórica (HAIR et al, 2009).

Um modelo convencional em MEE consiste em duas partes. A primeira é o modelo de mensuração, que mostra como variáveis medidas se juntam para representar constructos, e a segunda é o modelo estrutural, que mostra como os constructos são associados uns com os outros. Essas relações são demonstradas de forma visual em um diagrama de caminhos, onde uma seta é desenhada dos constructos latentes para as variáveis que são indicadoras dos constructos. Constructos são representados por elipses ou círculos e variáveis medidas são representadas por quadrados.

Os modelos de mensuração e estrutural utilizado nesse estudo estão representados em conjunto na ilustração 5. O modelo de mensuração descreve que as questões 1 à 8 estão relacionadas a Autodirecionamento (AD), as questões 9 à 14 estão relacionadas a Orientação 
pelos Valores (AV), as questões 15 à 22 estão relacionadas a Mobilidade Psicológica (MP) e as questões de 23 à 27 estão relacionadas a Mobilidade Física (MF). O modelo estrutural descreve que $\mathrm{AD}$ e OV estão relacionados à carreira proteana e MP e MF estão relacionados à carreira sem fronteiras (SF). Tanto a carreira proteana quanto a sem fronteiras são atitudes de carreira (AC).

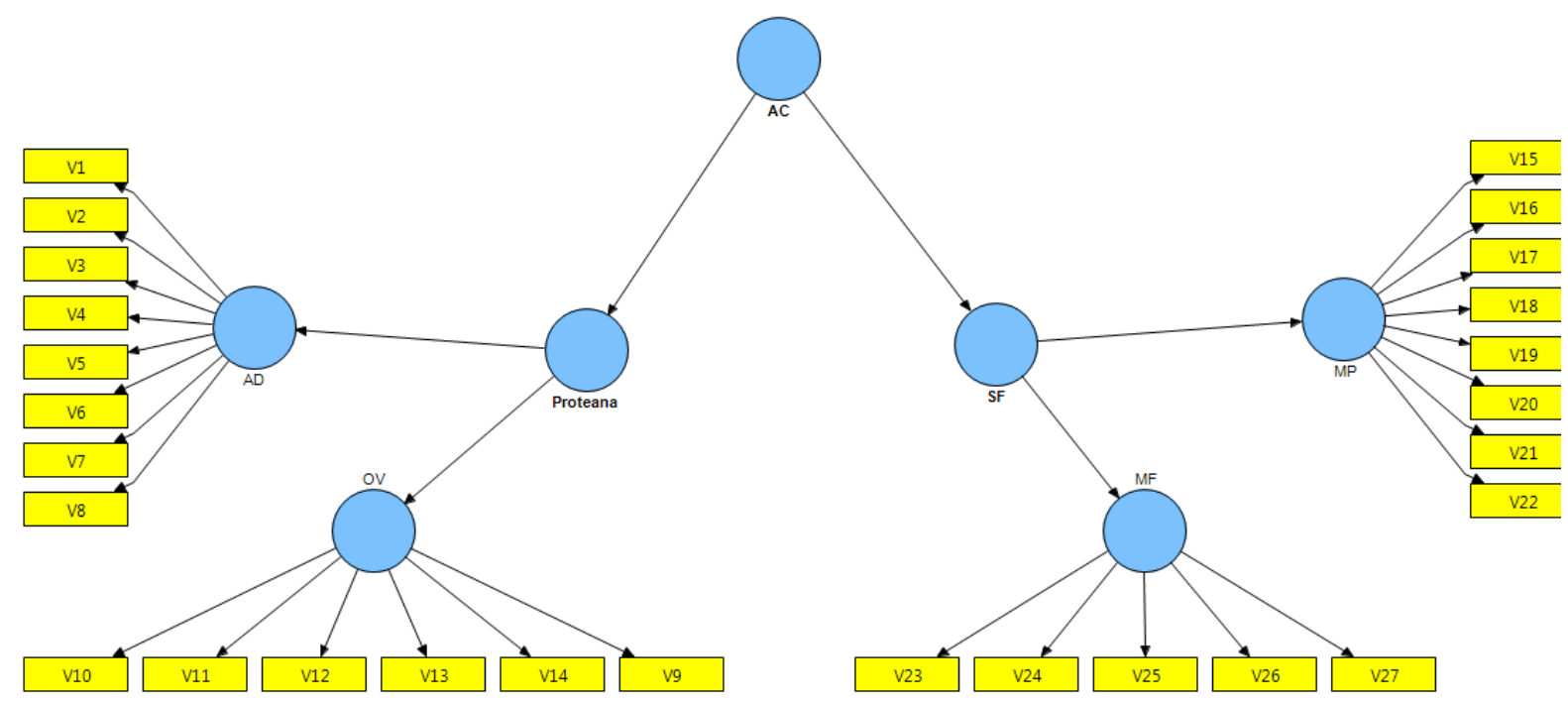

Ilustração 5 - Modelo teórico de mensuração e estrutural

Como forma de validação do modelo multivariado, foi utilizada a abordagem Bootstrapping, que extrai um grande número de sub-amostras e estima modelos para cada uma delas (HAIR et al, 2009). O SMART PLS apresenta os resultados do teste da distribuição $t$ de Student considerando várias amostras. De acordo com o valor de $t$ pode-se definir se os coeficientes padronizados são significantes. A hipótese nula $\mathrm{H} 0$ é que os coeficientes sejam todos iguais a zero contra a hipótese alternativa $\mathrm{H} 1$ que pelo menos um dos coeficientes é diferente de zero. Será considerado para esses testes o nível descritivo de 5\%.

O modelo foi estimado pelos métodos dos Mínimos Quadrados Parciais PLS-PM (Partial Least Squares Path Modeling) utilizando o software SMART PLS v. 2.0 M3.

Os principais indicadores e valores mínimos que devem ser analisados para as análises fatoriais são (HAIR et al, 2009): 
- Tamanho da amostra: mínimo de 10 observações por variável, que representaria 270 respondentes. A amostra deste estudo apresenta 88 observações por variável;

- Alfa de Cronbach: medida de confiabilidade que varia de 0 a 1 , sendo os valores de 0,6 e 0,7 considerados o limite inferior de aceitabilidade;

- Medida de Adequação da Amostra (MSA): medida para quantificar o grau de intercorrelações entre as variáveis e a adequação da análise fatorial. O valor mínimo aceitável é de 0,50 ;

- Teste de Esfericidade de Bartlett: outro modo de determinar a adequação da análise fatorial. É um teste estatístico da significância geral de todas as correlações em uma matriz de correlação. A significância deve ser inferior a 0,05;

- Comunalidade: método para procurar por variáveis que não sejam adequadamente explicadas pela solução fatorial, representando a quantia de variância explicada pela solução fatorial para cada variável. O pesquisador deve analisar as comunalidades para avaliar se as variáveis atendem níveis aceitáveis de explicação. Considerando o tamanho da amostra, aceitam-se comunalidades acima de 0,3 nesse estudo;

- Carga fatorial: correlação entre as variáveis originais e os fatores. Para estudos com amostras de mais de 350 respondentes pode se considerar variáveis cuja carga fatorial seja superior a 0,3 ;

- Variância extraída ou AVE (Average Variance Extracted): indicador de convergência da AFC. Deve ser superior a 0,5;

- Confiabilidade composta (composite reliability): é uma medida de consistência interna dos indicadores do constructo, descrevendo o grau em que eles indicam o constructo latente em comum. Deve ser superior a 0,7 . 


\subsubsection{Classificação de acordo com as atitudes de carreira}

Os indivíduos foram classificados utilizando a Análise de Agrupamentos no software SPSS. A Análise de Agrupamentos é uma técnica analítica para desenvolver subgrupos significativos de indivíduos ou objetos. O objetivo é classificar uma amostra de indivíduos em um número menor de grupos mutuamente excludentes, com base nas similaridades entre eles, maximizando a homogeneidade dentro dos grupos, ao mesmo tempo em que se maximiza a heterogeneidade entre os grupos (HAIR et al, 2009).

Ela difere da análise fatorial, pois a primeira agrega objetos enquanto a segunda agrega variáveis. Além disso, a análise fatorial faz os agrupamentos com base nos padrões de variação ou correlação nos dados, enquanto a análise de agrupamentos faz agregados de forma a minimizar a variância dentro dos grupos e maximizar a variância entre grupos.

Segundo Hair et al (2009), como a análise de agrupamentos é uma técnica descritiva e pode apresentar soluções variadas, é interessante utilizar a fundamentação conceitual estabelecida. Nesse caso foram utilizados como base os perfis conceituais de carreira definidos por Briscoe e Hall (2006). Apesar de ser vista como uma técnica exploratória, a análise de agrupamentos pode ser usada para fins confirmatórios. Em tais casos, uma tipologia proposta (classificação com base teórica) pode ser comparada com aquela obtida pela análise de agrupamentos.

A seleção da solução final exige muito do julgamento do pesquisador e também da base conceitual. Nesse caso, a partir de 4 dimensões é possível descrever 16 perfis de carreira com base nas combinações da alta ou baixa presença das atitudes descritas em cada dimensão. Esse foi o número máximo de agrupamentos analisado, apesar de a teoria descrever 8 perfis mais prováveis.

Os agrupamentos podem ser realizados por técnicas hierárquicas e não hierárquicas. Nos métodos hierárquicos, tais como o Ward, a seleção de qual par de agrupamentos serão combinados é baseada na combinação de agregados que minimiza a soma interna de quadrados no conjunto completo de agrupamentos separados ou disjuntos. Em cada passo, os dois agrupamentos combinados são aqueles que minimizam o aumento da soma total de quadrados em todas as variáveis em todos os agrupamentos. 
Os métodos não hierárquicos, tais como o K-means, não envolvem o processo de construção em árvores, em vez disso, designam objetos a agrupamentos assim que o número de agregados a serem formados tenha sido especificado. Nesse método, a primeira tarefa é especificar as sementes de agrupamento ou pontos de partida para cada agregado. A segunda tarefa é designar cada observação a uma semente de agrupamento com base na similaridade. O quadro 21 descreve as vantagens e desvantagens dos dois métodos.

Quadro 21 - Vantagens e desvantagens dos métodos de agrupamento hierárquico e não hierárquico

\begin{tabular}{|c|c|c|c|}
\hline \multicolumn{2}{|c|}{ Hierárquico } & \multicolumn{2}{c|}{ Não hierárquico } \\
\hline Vantagens & Desvantagens & Vantagens & Desvantagens \\
$\begin{array}{c}\text { Mais populares } \\
\text { facilmente } \\
\text { disponíveis }\end{array}$ & $\begin{array}{c}\text { Combinações iniciais } \\
\text { indesejáveis podem } \\
\text { persistir }\end{array}$ & $\begin{array}{c}\text { Resultados menos suscetíveis } \\
\text { a observações atípicas nos } \\
\text { dados, à medida de distância } \\
\text { usada e à inclusão de variáveis } \\
\text { irrelevantes ou inadequadas }\end{array}$ & $\begin{array}{c}\text { Depende da habilidade do } \\
\text { pesquisador para selecionar os } \\
\text { pontos sementes de acordo com } \\
\text { alguma base prática, objetiva ou } \\
\text { teórica }\end{array}$ \\
\hline $\begin{array}{c}\text { Simplicidade e } \\
\text { rapidez }\end{array}$ & $\begin{array}{c}\text { Problemas com } \\
\text { observações atípicas }\end{array}$ & $\begin{array}{c}\text { Podem examinar conjuntos } \\
\text { grandes de dados }\end{array}$ & $\begin{array}{c}\text { Soluções diferem com } \\
\text { mudanças de sementes gerando } \\
\text { uma maior dificuldade para } \\
\text { selecionar a melhor resposta }\end{array}$ \\
\hline & $\begin{array}{c}\text { Não tratáveis para } \\
\text { analisar amostras } \\
\text { muito grandes }\end{array}$ & & \\
& $\begin{array}{c}\text { Tendem a distribuir } \\
\text { os respondentes em } \\
\text { grupos de tamanhos } \\
\text { semelhantes }\end{array}$ & & \\
\hline
\end{tabular}

Fonte: adaptado de HAIR et al, 2009, p. 453-454

A análise de agrupamentos é uma técnica descritiva sem propriedades inferenciais. É comum que métodos diferentes gerem resultados distintos, ficando a critério do pesquisador a escolha da melhor opção. A comparação com a teoria ou alguma tipologia pré-concebida é fundamental para análise da qualidade do agrupamento (HAIR et al, 2009).

A especificação de pontos sementes de agrupamento pode ser feita ao acaso ou especificada pelo pesquisador. A abordagem via pesquisador é geralmente a opção preferida por considerar a base conceitual ou empírica para as sementes (HAIR et al, 2009, p. 471).

Como o objetivo do estudo é analisar os perfis de carreira predominantes, optou-se pela técnica não hierárquica, já que as técnicas hierárquicas tendem a distribuir os respondentes em grupos de tamanhos iguais. Além disso, as divisões dos grupos deveriam respeitar as combinações de altas e baixas atitudes de carreira dentro das quatro dimensões. Essa divisão 
em grupos com essas características só poderiam ser obtidas com a definição de sementes para separação dos grupos. As técnicas não hierárquicas também são mais adequadas para amostras grandes como a amostra utilizada nesse estudo.

As sementes foram definidas com base nas combinações dos 16 perfis de carreira possíveis e nos 8 perfis descritos como mais comuns pela teoria. Briscoe e Hall (2006) especificam os perfis em termos teóricos e a definição de alto ou baixo, em termos quantitativos, não é clara. Nesse estudo, foram utilizados valores absolutos para as sementes, sendo considerado $-0,5 \mathrm{o}$ ponto semente indicativo de baixa atitude no fator e $+0,5$ o ponto semente indicativo de alta atitude no fator.

Com base nos centroides resultantes da análise de agrupamento, foram classificados como alta atitude no fator os centroides acima de zero, e como baixa atitude no fator os centroides abaixo de zero. Centroides com valores próximos a zero tiveram sua significância avaliada pelo método Mann-Whitney.

Os agrupamentos foram gerados pelo método não hierárquico $K$-means no software SPSS.

\subsubsection{Influência das características demográficas e profissionais dos indivíduos em suas atitudes e perfis de carreira}

A análise da influência entre as características demográficas e profissionais nas atitudes de carreira e nos perfis de carreira encontrados na análise de agrupamentos foi feita através do teste de hipóteses Qui-Quadrado.

Martins e Theóphilo (2009) recomendam a utilização do teste Qui-Quadrado quando se quer estudar a associação, ou dependência, entre duas variáveis. A partir de uma tabela de dupla entrada ou de contingência, faz-se o cálculo das frequências esperadas baseado na definição de independência estatística entre dois eventos. Isto é: diz-se que X e Y são independentes se a distribuição conjunta de probabilidades de $(\mathrm{X}, \mathrm{Y})$ é igual ao produto das distribuições marginais de probabilidades de $\mathrm{X}$ e de $\mathrm{Y}$. A hipótese testada é $\mathrm{H} 0$ : as variáveis são independentes ou não são associadas e a hipótese alternativa H1: as variáveis são dependentes ou associadas. 
O teste Qui-Quadrado de associação é aconselhável quando o tamanho da amostra é razoavelmente grande e deve ser aplicado com maior cuidado se existirem frequências esperadas menores do que 5. Nesses casos, a solução é juntar grupos adjacentes evitando a frequência inferior a 5 .

O valor-p ou nível descritivo é utilizado para sintetizar o resultado do teste Qui-Quadrado e são considerados significantes testes cujo valor-p seja igual ou inferior a $5 \%$.

Foram realizadas análises descritivas das tabelas de frequências esperadas e observadas para investigação da associação entre as variáveis e atitudes/perfis de carreira. Foram feitas análises somente das associações estatisticamente significantes. 


\section{ANÁLISE DOS RESULTADOS}

Neste capítulo, os resultados do estudo serão apresentados. Inicialmente serão descritas as características demográficas e profissionais dos respondentes. Após isso serão apresentados os resultados das análises fatoriais e os resultados das análises de agrupamento que geraram os perfis de carreira. No final do capítulo, as associações entre as variáveis demográficas e as atitudes e perfis de carreira serão descritas.

\subsection{Perfil demográfico e profissional dos respondentes}

Neste item será descrito o perfil demográfico e profissional dos respondentes que compuseram a amostra analisada utilizando-se a estatística descritiva, para organização, sumarização e descrição dos dados.

A amostra é composta por respondentes nascidos entre 1982 e 1994, mas 83\% nasceram entre 1984 e 1990, ou seja, tem idade entre 22 e 28 anos. A idade média é de 25 anos.

Tabela 1 - Ano de nascimento e idade dos respondentes

\begin{tabular}{|c|c|c|c|}
\hline Ano de Nascimento & Idade aproximada & Número de Respondentes & $\%$ \\
\hline 1982 & 30 & 44 & $2 \%$ \\
\hline 1983 & 29 & 178 & $7 \%$ \\
\hline 1984 & 28 & 216 & $9 \%$ \\
\hline 1985 & 27 & 264 & $11 \%$ \\
\hline 1986 & 26 & 322 & $14 \%$ \\
\hline 1987 & 25 & 354 & $15 \%$ \\
\hline 1988 & 24 & 344 & $14 \%$ \\
\hline 1989 & 23 & 267 & $11 \%$ \\
\hline 1990 & 22 & 197 & $8 \%$ \\
\hline 1991 & 21 & 112 & $5 \%$ \\
\hline 1992 & 20 & 31 & $1 \%$ \\
\hline 1993 & 19 & 31 & $1 \%$ \\
\hline 1994 & 18 & 16 & $1 \%$ \\
\hline
\end{tabular}

As mulheres são maioria somando $57 \%$ dos respondentes, proporção um pouco superior à média nacional que é de 51\% (IBGE, 2012). O grau de escolaridade da amostra é alto, sendo 
$71 \%$ graduados e $21 \%$ pós-graduados. De acordo com os dados da RAIS (Relação Anual de Informações Sociais) de 2009, apenas $17,8 \%$ dos trabalhadores brasileiros tem ensino superior (DIEESE, 2011).

$84 \%$ dos respondentes são solteiros e $93 \%$ não têm filhos. As faixas de renda individuais são variadas dentro da amostra, conforme mostra a tabela 2 . Aproximadamente $59 \%$ da amostra tem rendimento superior ao rendimento médio do brasileiro, que é de $\mathrm{R} \$ 1.202,50$, de acordo com os dados do censo 2010 (IBGE, 2012).

Tabela 2 - Faixa de renda individual média mensal dos respondentes

\begin{tabular}{|c|c|}
\hline Renda individual & \% de respondentes \\
\hline Sem rendimento & $5 \%$ \\
\hline até $\mathrm{R} \$ 622,00$ & $7 \%$ \\
\hline entre $\mathrm{R} \$ 622,00$ e $\mathrm{R} \$ 1.244,00$ & $29 \%$ \\
\hline entre $\mathrm{R} \$ 1.244,00$ e $\mathrm{R} \$ 1.866,00$ & $20 \%$ \\
\hline entre $\mathrm{R} \$ 1.866,00$ e $\mathrm{R} \$ 3.110,00$ & $20 \%$ \\
\hline entre $\mathrm{R} \$ 3.110,00$ e $\mathrm{R} \$ 6.220,00$ & $16 \%$ \\
\hline Mais de $\mathrm{R} \$ 6.220,00$ & $3 \%$ \\
\hline
\end{tabular}

A tabela 3 mostra as faixas de renda familiar, indicando níveis superiores às faixas de renda individual. Conclui-se que apesar da amostra ser composta na maioria por indivíduos solteiros, existe um complemento de renda para composição da renda familiar, provavelmente proveniente dos pais dos respondentes. Tendo em vista os dados do censo 2010, que apontam que $42 \%$ dos domicílios tem rendimento nominal mensal de até 2 salários mínimos e $47 \%$ tem rendimento nominal mensal entre 2 e 10 salários mínimos (IBGE, 2012), conclui-se que a amostra é composta por poucos indivíduos de baixa renda familiar e tem maior proporção de indivíduos de alta renda, sendo aproximadamente $75 \%$ pertencentes as classes A e B, de acordo com a classificação proposta pela ABEP (2012).

Tabela 3 - Faixa de renda familiar média mensal dos respondentes

\begin{tabular}{|c|c|}
\hline Renda familiar & \% de respondentes \\
\hline até $\mathrm{R} \$ 1.244,00$ & $7 \%$ \\
\hline entre $\mathrm{R} \$ 1.244,00$ e $\mathrm{R} \$ 2.488,00$ & $18 \%$ \\
\hline entre $\mathrm{R} \$ 2.448,00$ e $\mathrm{R} \$ 6.220,00$ & $40 \%$ \\
\hline entre $\mathrm{R} \$ 6.220,00$ e $\mathrm{R} \$ 12.440,00$ & $22 \%$ \\
\hline Mais de $\mathrm{R} \$ 12.440$ & $13 \%$ \\
\hline
\end{tabular}


Os respondentes residem predominantemente no Sudeste (72\%) do país, conforme mostra o gráfico 1. Dentre o total de respondentes, 50\% residem no estado de São Paulo, $10 \%$ em Minas Gerais e $10 \%$ no Rio de Janeiro.

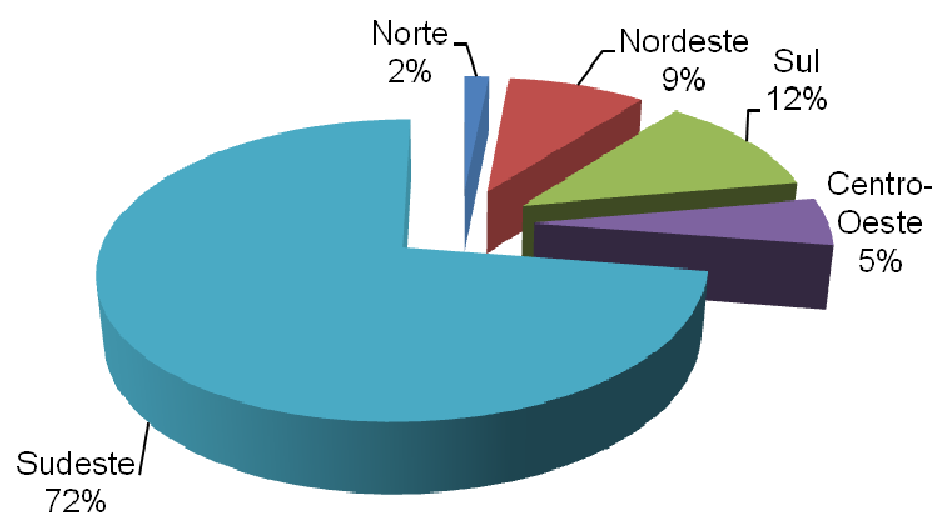

Gráfico 1 - Região geográfica de residência dos respondentes

O uso da internet é alto dentre os respondentes. Apenas 2\% passam menos de uma hora por dia na rede e $23 \%$ passam mais de 8 horas por dia conectado. Esse resultado vai ao encontro da teoria sobre a Geração Y, que inclusive é nomeada por alguns autores como Geração Internet (TAPSCOTT, 2010), por sua alta inserção e facilidade de uso dessa tecnologia. O gráfico 2 indica o tempo médio de uso diário da internet na amostra.

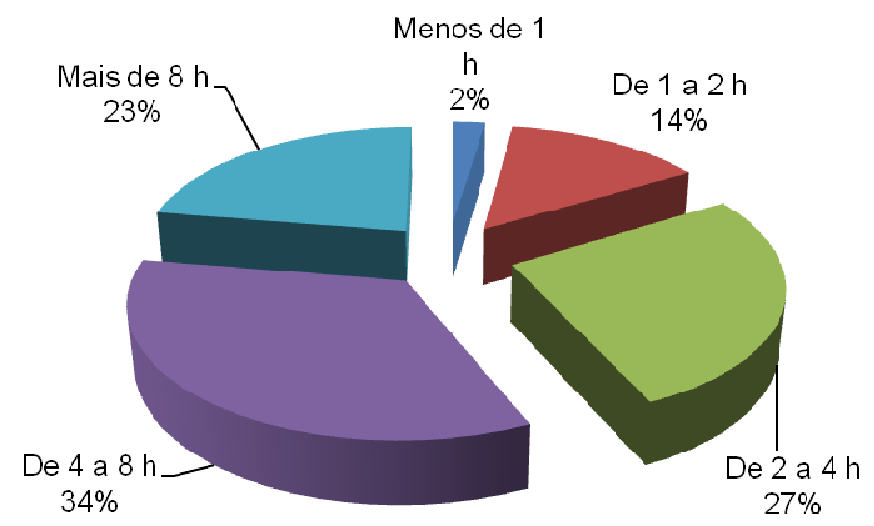

Gráfico 2 - Tempo médio de uso diário da internet dos respondentes

82,5\% estão trabalhando atualmente. O tempo de experiência profissional é variado na amostra, sendo que $33 \%$ tem menos de 3 anos de experiência profissional, conforme indica a tabela 4. 
Tabela 4 - Anos de experiência profissional dos respondentes

\begin{tabular}{|c|c|}
\hline Anos de experiência profissional & \% de respondentes \\
\hline Entre 1 e 2 anos & $16 \%$ \\
\hline Entre 2 e 3 anos & $17 \%$ \\
\hline Entre 3 e 5 anos & $28 \%$ \\
\hline Entre 5 e 7 anos & $21 \%$ \\
\hline Mais de 7 anos & $17 \%$ \\
\hline
\end{tabular}

A mobilidade física, indicada pelo número de empresas para as quais os respondentes trabalharam nos últimos 5 anos, é descrita na tabela 5. 59\% dos respondentes trabalharam para 2 ou 3 organizações nos últimos 5 anos, sugerindo um tempo médio de empresa de 1,5 à 2,5 anos. $23 \%$ indicaram uma mobilidade física maior, trabalhando para 4 ou mais empregadores. Em média, os respondentes trabalharam em 3 organizações nos últimos 5 anos.

Os indicadores da pesquisa sobre rotatividade desenvolvida pelo DIEESE (2011), com base nos dados da RAIS, apresentam um tempo médio de emprego de 3,9 anos em 2009, que coloca a amostra em uma posição de maior movimentação entre empregadores do que a média identificada na pesquisa nacional. A pesquisa também indica que o grupo com maior número de desligamentos ao ano é dos jovens até 29 anos de idade, mas não informa a rotatividade específica desse grupo.

Tabela 5 - Número de empresas para as quais os respondentes trabalharam nos últimos 5 anos

\begin{tabular}{|c|c|}
\hline $\begin{array}{c}\text { Número de empresas para as quais } \\
\text { já trabalhou nos últimos 5 anos }\end{array}$ & \% de respondentes \\
\hline 0 & $1 \%$ \\
\hline 1 & $12 \%$ \\
\hline 2 & $27 \%$ \\
\hline 3 & $32 \%$ \\
\hline 4 & $15 \%$ \\
\hline 5 & $8 \%$ \\
\hline 6 & $3 \%$ \\
\hline 7 ou mais & $3 \%$ \\
\hline
\end{tabular}

$50 \%$ da amostra atua em cargos de analista, auxiliar ou assistente e $18 \%$ são estagiários. Apenas $15 \%$ estão em cargos de gestão. A tabela 6 mostra essa distribuição. $11 \%$ dos respondentes indicaram a opção "outros" em cargo e diversas pessoas especificaram suas ocupações atuais. Foi possível identificar que dentre esses $13 \%$ são professores, $12 \%$ são 
estudantes, $9 \%$ são técnicos e $8 \%$ são engenheiros. Os demais respondentes indicaram as mais diversas ocupações, tais como, babá, policial, vendedor, jornalista, profissional autônomo, etc.

Tabela 6 - Cargo dos respondentes

\begin{tabular}{|c|c|}
\hline Cargo & \% de respondentes \\
\hline Diretor / Gerente & $3 \%$ \\
\hline Coordenador / Supervisor / Consultor & $12 \%$ \\
\hline Analista / Auxiliar / Assistente & $50 \%$ \\
\hline Trainee & $5 \%$ \\
\hline Estagiário & $18 \%$ \\
\hline Outro & $11 \%$ \\
\hline
\end{tabular}

É interessante notar a presença de pessoas de diversas ocupações interessadas em responder uma pesquisa sobre carreira. Isso pode indicar que essas pessoas tem uma visão do conceito moderno de carreira, que não necessariamente apresenta relação com determinadas profissões ou com estruturas hierárquicas e considera a carreira como sequencia de experiências profissionais ao longo da vida (HALL, 2004).

O fato de a amostra apresentar uma alta proporção de indivíduos de alta escolaridade, alta renda e alto uso diário da internet pode estar relacionado à técnica de coleta de dados, ou seja, o uso do questionário eletrônico disponível na internet, já que essa técnica costuma obter respostas de pessoas desse perfil (VASCONCELLOS; GUEDES, 2007).

Como o público alvo teve como base os indivíduos cadastrados em um banco de dados de uma empresa de recrutamento e seleção, ou seja, pessoas que buscaram ou estão buscando um novo emprego, é possível que isso proporcionado uma amostra de indivíduos que apresentam maior movimentação entre empregadores nos últimos 5 anos.

A tabela 7 apresenta a estatística descritiva das questões das escalas de atitudes de carreira proteana e sem fronteiras. O coeficiente de variação é calculado pela divisão do desvio padrão pela média. Quando é menor que 15\%, é considerado de dispersão baixa; quando está entre $15 \%$ e $30 \%$, a dispersão é média; e quando é superior a 30\%, a dispersão é alta (COSTA, 2011). 
Tabela 7 - Estatística descritiva das questões das escalas de atitudes de carreira proteana e sem fronteiras

\begin{tabular}{|c|c|c|c|c|c|}
\hline $\mathbf{N}^{\circ}$ & Questão & Média & $\begin{array}{l}\text { Desvio } \\
\text { Padrão }\end{array}$ & $\begin{array}{c}\text { Coeficien } \\
\text { te de } \\
\text { variação }\end{array}$ & Dispersão \\
\hline 1 & $\begin{array}{l}\text { Quando oportunidades de desenvolvimento não me } \\
\text { foram oferecidas por minha empresa, busquei-as por } \\
\text { mim mesmo }\end{array}$ & 4,3030 & 0,9065 & $21,1 \%$ & média \\
\hline 2 & $\begin{array}{l}\text { Sou responsável por meu sucesso ou fracasso em minha } \\
\text { carreira }\end{array}$ & 4,3013 & 0,8501 & $19,8 \%$ & média \\
\hline 3 & $\begin{array}{l}\text { De um modo geral, tenho uma carreira bastante } \\
\text { independente e dirigida por mim }\end{array}$ & 3,4491 & 1,0717 & $31 \%$ & alta \\
\hline 4 & $\begin{array}{l}\text { Liberdade para escolher minha própria trajetória de } \\
\text { carreira é um dos meus valores mais importantes }\end{array}$ & 4,0585 & 0,9774 & $24,1 \%$ & média \\
\hline 5 & Estou no comando de minha própria carreira & 3,6961 & 1,1259 & $30,5 \%$ & alta \\
\hline 6 & $\begin{array}{l}\text { No final das contas, dependo de mim mesmo para } \\
\text { avançar em minha carreira }\end{array}$ & 4,1561 & 0,9796 & $23,6 \%$ & média \\
\hline 7 & $\begin{array}{l}\text { No que diz respeito à minha carreira, quem toma as } \\
\text { decisões sou eu }\end{array}$ & 4,0766 & 0,9896 & $24,3 \%$ & média \\
\hline 8 & $\begin{array}{l}\text { Em minhas experiências passadas, confiei mais em mim } \\
\text { mesmo do que em outras pessoas para encontrar um } \\
\text { novo emprego, quando necessário }\end{array}$ & 3,4747 & 1,1605 & $33 \%$ & alta \\
\hline 9 & $\begin{array}{l}\text { Eu conduzo minha própria carreira, baseado(a) em } \\
\text { minhas prioridades pessoais e não nas prioridades de } \\
\text { meu empregador }\end{array}$ & 2,9945 & 1,2375 & $41 \%$ & alta \\
\hline 10 & $\begin{array}{l}\text { Não é muito importante para mim a forma com que as } \\
\text { pessoas avaliam as escolhas que eu faço em minha } \\
\text { carreira }\end{array}$ & 3,8371 & 1,1848 & $31 \%$ & alta \\
\hline 11 & $\begin{array}{l}\text { O que mais importa para mim é como eu me sinto em } \\
\text { relação a meu sucesso na carreira e não como outras } \\
\text { pessoas se sentem a respeito disso }\end{array}$ & 3,9360 & 1,1749 & $29,8 \%$ & média \\
\hline 12 & $\begin{array}{l}\text { Sigo a minha própria consciência se a minha empresa } \\
\text { solicitar que eu faça algo que seja contra os meus } \\
\text { valores }\end{array}$ & 3,4941 & 1,1358 & $33 \%$ & alta \\
\hline 13 & $\begin{array}{l}\text { O que eu acho que está certo em minha carreira é mais } \\
\text { importante para mim do que o que minha empresa acha }\end{array}$ & 3,6301 & 1,1726 & $32 \%$ & alta \\
\hline 14 & $\begin{array}{l}\text { Em minhas experiências passadas, eu segui meus } \\
\text { próprios valores mesmo quando a empresa me pediu } \\
\text { para fazer algo com o qual eu não concordava }\end{array}$ & 4,3001 & 1,0076 & $23,4 \%$ & média \\
\hline 15 & Procuro tarefas que me permitam aprender algo novo & 3,7635 & 1,1871 & $32 \%$ & alta \\
\hline 16 & $\begin{array}{l}\text { Gostaria de trabalhar em projetos com pessoas de várias } \\
\text { organizações }\end{array}$ & 4,0598 & 1,1106 & $27,4 \%$ & média \\
\hline 17 & $\begin{array}{l}\text { Gosto de tarefas que requeiram que eu trabalhe fora da } \\
\text { organização }\end{array}$ & 4,0265 & 1,0550 & $26,2 \%$ & média \\
\hline 18 & $\begin{array}{l}\text { Gosto de tarefas em meu trabalho que requeiram que eu } \\
\text { trabalhe além do meu próprio departamento }\end{array}$ & 4,1772 & 1,0257 & $24,6 \%$ & média \\
\hline 19 & $\begin{array}{l}\text { Gosto de trabalhar com pessoas fora da minha } \\
\text { organização }\end{array}$ & 3,1574 & 1,3211 & $42 \%$ & alta \\
\hline 20 & $\begin{array}{l}\text { Gosto de trabalhos que requeiram que eu interaja com } \\
\text { pessoas de várias organizações diferentes }\end{array}$ & 4,4996 & 0,8172 & $18,2 \%$ & média \\
\hline 21 & $\begin{array}{l}\text { No passado, busquei oportunidades que me permitissem } \\
\text { trabalhar fora da organização }\end{array}$ & 3,0303 & 1,2291 & $41 \%$ & alta \\
\hline 22 & $\begin{array}{l}\text { Sinto-me motivado quando enfrento experiências e } \\
\text { situações novas }\end{array}$ & 3,8628 & 1,1886 & $31 \%$ & alta \\
\hline 23 & $\begin{array}{l}\text { Gosto da previsibilidade decorrente de se trabalhar } \\
\text { continuamente para a mesma organização }\end{array}$ & 3,5846 & 1,2654 & $35 \%$ & alta \\
\hline 24 & $\begin{array}{l}\text { Eu me sentiria bastante perdido se não pudesse } \\
\text { trabalhar para a minha atual organização }\end{array}$ & 168 & 1,2336 & $32 \%$ & alta \\
\hline 25 & Prefiro permanecer em uma empresa com a qual eu & 3,8422 & 1,2974 & $34 \%$ & alta \\
\hline
\end{tabular}




\begin{tabular}{|l|l|c|c|c|c|}
\hline \multicolumn{2}{|c|}{ Questão } & Média & $\begin{array}{c}\text { Desvio } \\
\text { Padrão }\end{array}$ & $\begin{array}{c}\text { Coeficien } \\
\text { te de } \\
\text { variação }\end{array}$ & Dispersão \\
\hline & $\begin{array}{l}\text { esteja familiarizado do que procurar por outro emprego } \\
\text { em outro lugar }\end{array}$ & & & & \\
\hline 26 & $\begin{array}{l}\text { Se minha empresa proporcionasse emprego vitalício, eu } \\
\text { nunca iria querer procurar trabalho em outras } \\
\text { organizações }\end{array}$ & 4,3030 & 0,9065 & $21,1 \%$ & média \\
\hline 27 & $\begin{array}{l}\text { O meu ideal de carreira seria trabalhar apenas para uma } \\
\text { única organização }\end{array}$ & 4,3013 & 0,8501 & $19,8 \%$ & média \\
\hline
\end{tabular}

\subsection{Validade das escalas de atitudes de carreira}

O primeiro objetivo específico é a verificação da validade das escalas de atitudes de carreira sem fronteiras e proteana. Faz-se necessário a análise da confiabilidade e consistência interna do instrumento utilizado antes da análise dos resultados obtidos.

Os resultados desses dois testes e seus índices de confiabilidade serão apresentados separadamente.

\subsubsection{Análise Fatorial Exploratória (AFE)}

A técnica de AFE utilizada foi a Análise de Componentes Principais. A Análise de Componentes Principais é usada quando o objetivo é resumir a maior parte da informação original (variância) a um número mínimo de fatores (HAIR et al, 2009).

Para a análise fatorial, os dados foram rotacionados para redistribuir a variância dos fatores, maximizando as cargas fatoriais, com o objetivo de atingir um padrão fatorial mais simples e teoricamente mais significativo (HAIR et al, 2009). Foi utilizado o critério de rotação ortogonal VARIMAX.

Os resultados obtidos indicam um alfa de Cronbach de 0,832 , confirmando sua consistência interna. A MSA foi de 0,864, valor considerado admirável por Hair et al, 2009. Todas as variáveis tiveram MSA acima de 0,5, valor mínimo de adequação da variável à análise 
fatorial, sendo 0,735 o menor valor encontrado. Outra medida importante é o teste de esfericidade de Bartlett, que teve significância zero, confirmando a aplicação da análise fatorial.

Analisando a comunalidade das variáveis, observou-se que apenas as questões 1 e 8 apresentaram comunalidade inferior à $30 \%$, indicando uma baixa explicação pela solução fatorial.

A AFE indicou, de acordo com o critério do teste scree, 4 grupos de perguntas representando as 4 dimensões de carreira propostas pela teoria, revalidando o questionário, apesar das pequenas alterações em algumas palavras. A ilustração 6 mostra os resultados do teste scree.

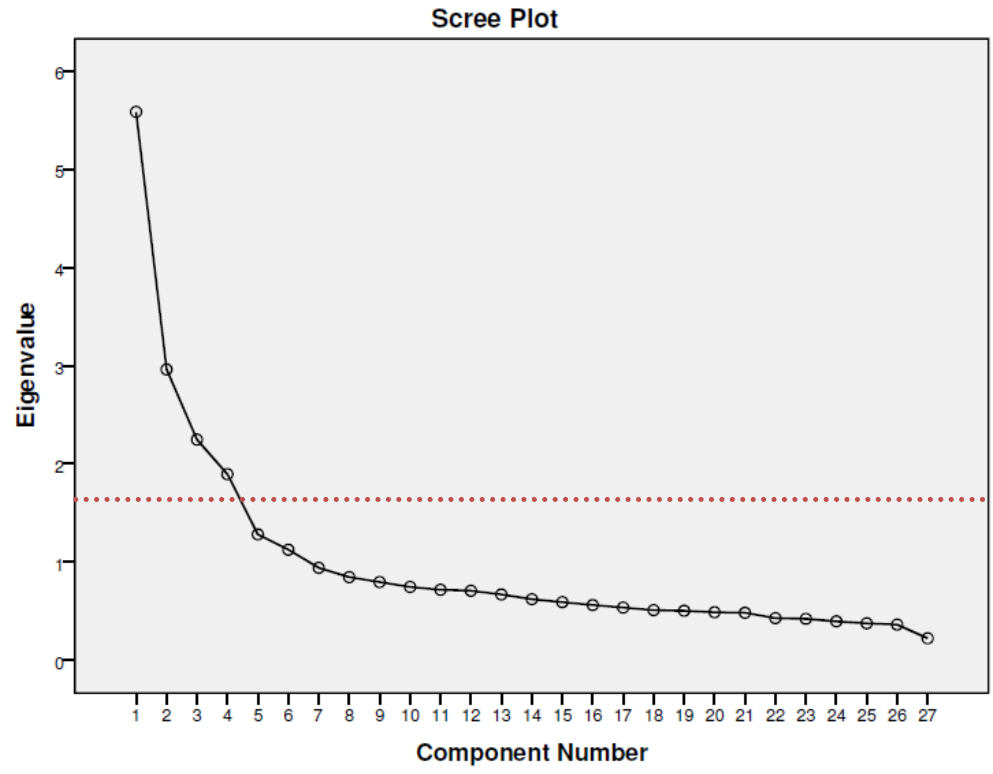

Ilustração 6 - Resultados do teste scree da AFE (questionário completo)

Esses 4 fatores acumulam 47\% da variância das 27 questões, conforme indica a tabela 8.

Tabela 8 - Variância total explicada pela AFE - Análise de Componentes Principais (questionário completo)

\begin{tabular}{|c|c|c|c|c|}
\hline Fator & Total & \% da Variância & \% Cumulativo & Nome do Fator \\
\hline 1 & 3,969 & 14,699 & 14,699 & Mobilidade Psicológica \\
\hline 2 & 3,471 & 12,854 & 27,553 & Auto Direcionamento \\
\hline 3 & 2,679 & 9,923 & 37,476 & Mobilidade Física \\
\hline 4 & 2,574 & 9,533 & 47,009 & Orientação pelos Valores \\
\hline
\end{tabular}


A matriz fatorial de cargas exibida na tabela 9 indica as cargas fatoriais de cada questão que compõe os fatores, considerando somente aquelas superiores a 0,3 , ou seja, somente as cargas fatoriais relevantes. Observam-se poucas questões com carga cruzada (questões 9, 15 e 22), indicando que as questões são explicativas dos fatores nos quais elas estão alocadas e indicando também a diferenciação entre as 4 dimensões de carreira. As questões estão divididas exatamente como descreve a teoria.

Tabela 9 - Matriz de cargas fatoriais da AFE (questionário completo)

\begin{tabular}{|c|c|c|c|c|c|}
\hline $\mathbf{N}^{\circ}$ & Questão & MP & AD & MF & $\mathbf{O V}$ \\
\hline 1 & $\begin{array}{l}\text { Quando oportunidades de desenvolvimento não me foram oferecidas por } \\
\text { minha empresa, busquei-as por mim mesmo }\end{array}$ & & 0,418 & & \\
\hline 2 & Sou responsável por meu sucesso ou fracasso em minha carreira & & 0,602 & & \\
\hline 3 & $\begin{array}{l}\text { De um modo geral, tenho uma carreira bastante independente e dirigida } \\
\text { por mim }\end{array}$ & & 0,644 & & \\
\hline 4 & $\begin{array}{l}\text { Liberdade para escolher minha própria trajetória de carreira é um dos } \\
\text { meus valores mais importantes }\end{array}$ & & 0,619 & & \\
\hline 5 & Estou no comando de minha própria carreira & & 0,755 & & \\
\hline 6 & $\begin{array}{l}\text { No final das contas, dependo de mim mesmo para avançar em minha } \\
\text { carreira }\end{array}$ & & 0,648 & & \\
\hline 7 & No que diz respeito à minha carreira, quem toma as decisões sou eu & & 0,694 & & \\
\hline 8 & $\begin{array}{l}\text { Em minhas experiências passadas, confiei mais em mim mesmo do que } \\
\text { em outras pessoas para encontrar um novo emprego, quando necessário }\end{array}$ & & 0,363 & & \\
\hline 9 & $\begin{array}{l}\text { Eu conduzo minha própria carreira, baseado(a) em minhas prioridades } \\
\text { pessoais e não nas prioridades de meu empregador }\end{array}$ & & 0,320 & & 0,522 \\
\hline 10 & $\begin{array}{l}\text { Não é muito importante para mim a forma com que as pessoas avaliam } \\
\text { as escolhas que eu faço em minha carreira }\end{array}$ & & & & 0,617 \\
\hline 11 & $\begin{array}{l}\text { O que mais importa para mim é como eu me sinto em relação a meu } \\
\text { sucesso na carreira e não como outras pessoas se sentem a respeito disso }\end{array}$ & & & & 0,628 \\
\hline 12 & $\begin{array}{l}\text { Sigo a minha própria consciência se a minha empresa solicitar que eu } \\
\text { faça algo que seja contra os meus valores }\end{array}$ & & & & 0,640 \\
\hline 13 & $\begin{array}{l}\text { O que eu acho que está certo em minha carreira é mais importante para } \\
\text { mim do que o que minha empresa acha }\end{array}$ & & & & 0,738 \\
\hline 14 & $\begin{array}{l}\text { Em minhas experiências passadas, eu segui meus próprios valores } \\
\text { mesmo quando a empresa me pediu para fazer algo com o qual eu não } \\
\text { concordava }\end{array}$ & & & & 0,639 \\
\hline 15 & Procuro tarefas que me permitam aprender algo novo & 0,435 & 0,376 & & \\
\hline 16 & Gostaria de trabalhar em projetos com pessoas de várias organizações & 0,754 & & & \\
\hline 17 & Gosto de tarefas que requeiram que eu trabalhe fora da organização & 0,705 & & & \\
\hline 18 & $\begin{array}{l}\text { Gosto de tarefas em meu trabalho que requeiram que eu trabalhe além do } \\
\text { meu próprio departamento }\end{array}$ & 0,721 & & & \\
\hline 19 & Gosto de trabalhar com pessoas fora da minha organização & 0,852 & & & \\
\hline 20 & $\begin{array}{l}\text { Gosto de trabalhos que requeiram que eu interaja com pessoas de várias } \\
\text { organizações diferentes }\end{array}$ & 0,837 & & & \\
\hline 21 & $\begin{array}{l}\text { No passado, busquei oportunidades que me permitissem trabalhar fora } \\
\text { da organização }\end{array}$ & 0,575 & & & \\
\hline 22 & Sinto-me motivado quando enfrento experiências e situações novas & 0,502 & 0,378 & & \\
\hline 23 & $\begin{array}{l}\text { Gosto da previsibilidade decorrente de se trabalhar continuamente para a } \\
\text { mesma organização }\end{array}$ & & & 0,611 & \\
\hline 24 & $\begin{array}{l}\text { Eu me sentiria bastante perdido se não pudesse trabalhar para a minha } \\
\text { atual organização }\end{array}$ & & & 0,657 & \\
\hline 25 & Prefiro permanecer em uma empresa com a qual eu esteja familiarizado & & & 0,745 & \\
\hline
\end{tabular}




\begin{tabular}{|c|l|c|c|c|}
\hline \multicolumn{1}{|c|}{$\mathbf{N}^{\circ}$} & Questão & & MP & MF \\
\hline 26 & $\begin{array}{l}\text { Se que procurar por outro emprego em outro lugar } \\
\text { querer procurar trabalho em outras organizações }\end{array}$ & & 0,786 & \\
\hline 27 & $\begin{array}{l}\text { O meu ideal de carreira seria trabalhar apenas para uma única } \\
\text { organização }\end{array}$ & & 0,735 & \\
\hline
\end{tabular}

É possível avaliar a consistência interna de cada dimensão e constructo por seu respectivo alfa de Cronbach. A tabela 10 indica a confiabilidade das quatro dimensões e dos constructos de carreira proteana e sem fronteiras, todos com alfas superiores a 0,7 , confirmando a consistência interna desses fatores.

Tabela 10 - Alfa de Cronbach das dimensões e constructos de carreira proteana e sem fronteiras (questionário completo)

\begin{tabular}{|c|c|}
\hline & Alfa de Cronbach \\
\hline Autodirecionamento & 0,773 \\
\hline Orientação para Valores & 0,723 \\
\hline Proteana & 0,792 \\
\hline Mobilidade Psicológica & 0,848 \\
\hline Mobilidade Física & 0,767 \\
\hline Sem Fronteiras & 0,818 \\
\hline
\end{tabular}

Devido a baixa carga fatorial das questões 8 e 15 e baixa comunalidade das questão 1 e 8 , optou-se por fazer uma nova análise fatorial excluindo essas questões.

De Bruin e Buchner (2010) também encontraram baixas cargas fatoriais nessas mesmas questões. Os autores criticam o fato de algumas questões questionarem sobre o passado e o impacto disso no modelo fatorial entre questões que estão predominantemente no presente. A questão 1 ("Quando oportunidades de desenvolvimento não me foram oferecidas por minha empresa, busquei-as por mim mesmo") e a questão 8 ("Em minhas experiências passadas, confiei mais em mim mesmo do que em outras pessoas para encontrar um novo emprego, quando necessário") são questões desse tipo e essa pode ser uma explicação para os problemas de comunalidade e baixa carga encontrados. Outra hipótese levantada pelos autores é a relação com a cultura nacional, no sentido que países com cultura coletivista prezam as relações sociais e o bem-estar da comunidade em detrimento de maior autonomia ou desejos pessoais. O Brasil apresenta uma cultura coletivista (HOSTEDE, 1997) e, portanto, o fato de confiar em outras pessoas para encontrar um novo emprego não necessariamente afeta a percepção de autodirecionamento na carreira. 
De Bruin e Buchner (2010) encontraram também problemas nas questões 21 e 23 que também questionam o passado, mas a análise fatorial realizada para esse estudo apresentou resultados satisfatórios para essas perguntas.

A questão 15 ("Procuro tarefas que me permitam aprender algo novo") pode contribuir pouco com a explicação da mobilidade psicológica porque não explicita que essas tarefas sejam entre limites departamentais ou organizacionais e os respondentes podem ter associado essa questão simplesmente ao interesse em aprender coisas novas, independente de implementá-las no trabalho (DE BRUIN; BUCHNER, 2010).

A nova análise fatorial exploratória excluindo as questões 1,8 e 15 gerou um alfa de Cronbach de 0,815 , valor levemente inferior ao encontrado anteriormente $(0,832)$, mas que ainda afirma a consistência interna. A perda de um pequeno valor do alfa de Cronbach do questionário geral é compensada pelo ganho de consistência interna no fator autodirecionamento. Considerando que um dos propósitos desse estudo é realizar agrupamentos com base nos resultados da análise fatorial, a alta consistência interna dos fatores é primordial para atender aos objetivos da pesquisa.

Tabela 11 - Comparação dos resultados do Alfa de Cronbach do questionário completo e do questionário sem as questões 1,8 e 15

\begin{tabular}{|c|c|c|}
\hline & $\begin{array}{c}\text { Alfa de Cronbach - } \\
\text { Questionário completo }\end{array}$ & $\begin{array}{c}\text { Alfa de Cronbach - Questionário } \\
\text { sem questões 1, 8 e 15 }\end{array}$ \\
\hline Autodirecionamento & 0,773 & 0,784 \\
\hline Orientação para Valores & 0,723 & 0,723 \\
\hline Proteana & 0,792 & 0,781 \\
\hline Mobilidade Psicológica & 0,848 & 0,848 \\
\hline Mobilidade Física & 0,767 & 0,767 \\
\hline Sem Fronteiras & 0,818 & 0,811 \\
\hline
\end{tabular}

A MSA geral foi de 0,852 e a MSA de todas as variáveis se mantiveram acima de 0,5 (limite mínimo), sendo 0,727 o menor valor encontrado. O teste de esfericidade de Bartlett manteve a significância zero, confirmando a aplicação da análise fatorial.

Com a retirada das questões 1 e 8, nenhuma questão apresentou comunalidade inferior à 30\%. 
Esses 4 fatores acumulam 50\% da variância das 24 questões, ou seja, a variância explicada subiu de $47 \%$ para $50 \%$ com a retirada das três questões, conforme mostra a tabela 12 .

Tabela 12 - Variância total explicada pela AFE - Análise de Componentes Principais (sem as perguntas 1, 8 e 15)

\begin{tabular}{|c|c|c|c|c|}
\hline Fator & Total & \% da Variância & \% Cumulativo & Nome do Fator \\
\hline 1 & 3,768 & 15,702 & 15,702 & Mobilidade Psicológica \\
\hline 2 & 3,062 & 12,757 & 28,459 & Auto Direcionamento \\
\hline 3 & 2,656 & 11,068 & 39,527 & Mobilidade Física \\
\hline 4 & 2,540 & 10,582 & 50,111 & Orientação pelos Valores \\
\hline
\end{tabular}

O teste scree continuou indicando a solução de 4 fatores como mais adequada. A ilustração 7 mostra os resultados do teste scree.

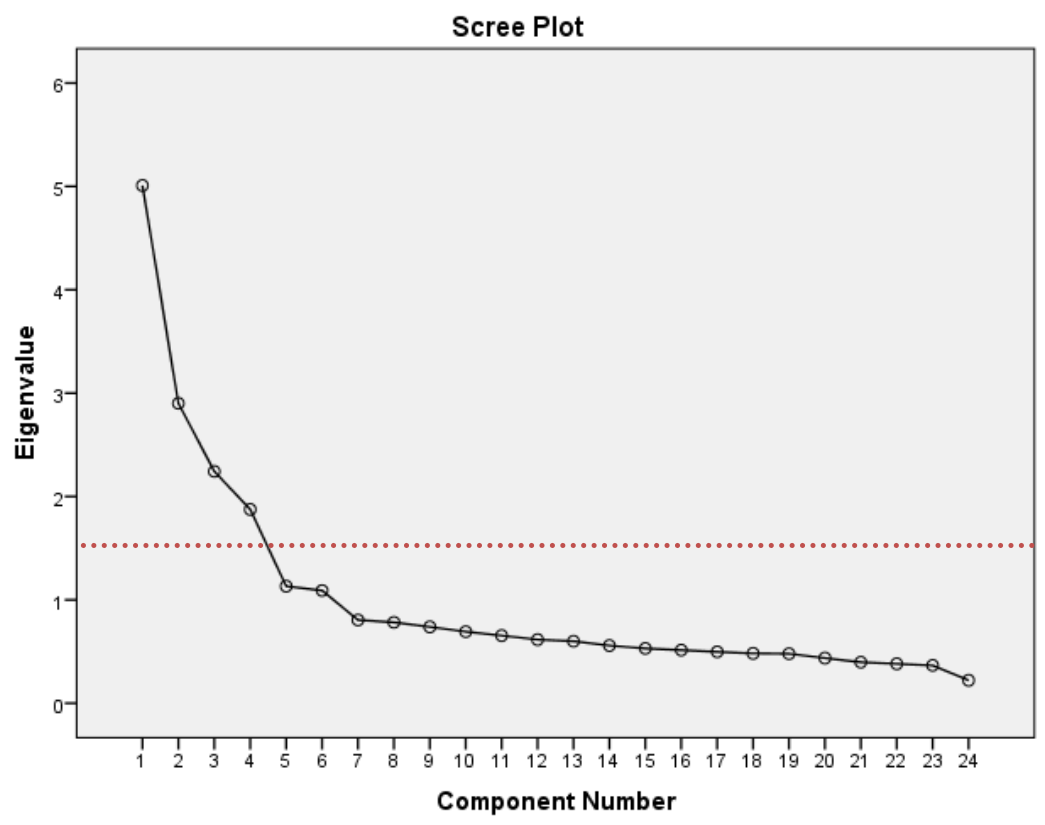

Ilustração 7 - Resultados do teste scree da AFE sem as questões 1, 8 e 15

A análise paralela também confirma a solução de 4 fatores, com a retirada das questões 1,8 e 15. A análise paralela tem sido considerada o procedimento mais confiável na verificação do número de fatores a serem retidos (HAYTON et al, 2004). A tabela 13 apresenta os resultados dos autovalores randômicos gerados pelo software Monte Carlo PCA for Parallel Analysis v. 2.5, com 500 replicações. 
Tabela 13 - Autovalores empíricos e autovalores randômicos gerados pelo Monte Carlo PCA for Parallel Analysis

\begin{tabular}{|c|c|c|c|c|}
\hline \multirow{2}{*}{ Fator } & \multicolumn{3}{|c|}{ Autovalores da matriz empírica } & \multirow{2}{*}{ Autovalores randômicos } \\
\cline { 2 - 4 } & Total & \% da Variância & \% Cumulativo & \\
\hline $\mathbf{1}$ & $\mathbf{5 , 0 0 9}$ & 20,869 & 20,869 & $\mathbf{1 , 1 8 4 6}$ \\
\hline $\mathbf{2}$ & $\mathbf{2 , 9 0 1}$ & 12,087 & 32,956 & 1,1577 \\
\hline $\mathbf{3}$ & $\mathbf{2 , 2 4 2}$ & 9,343 & 42,300 & 1,1365 \\
\hline $\mathbf{4}$ & $\mathbf{1 , 8 7 5}$ & 7,811 & 50,111 & 1,1182 \\
\hline $\mathbf{5}$ & 1,132 & 4,718 & 54,829 & 1,1013 \\
\hline
\end{tabular}

A matriz de cargas fatoriais exibida na tabela 14 indica cargas fatoriais superiores às encontradas anteriormente. Observa-se que não existem mais questões com carga cruzada, indicando que as questões se encaixam perfeitamente nos fatores e na teoria.

Tabela 14 - Matriz de cargas fatoriais da AFE (sem questões 1, 8 e 15)

\begin{tabular}{|c|c|c|c|c|c|}
\hline $\mathbf{N}^{\circ}$ & Questão & MP & AD & MF & $\mathbf{O V}$ \\
\hline 2 & Sou responsável por meu sucesso ou fracasso em minha carreira & & 0,594 & & \\
\hline 3 & $\begin{array}{l}\text { De um modo geral, tenho uma carreira bastante independente e dirigida } \\
\text { por mim }\end{array}$ & & 0,664 & & \\
\hline 4 & $\begin{array}{l}\text { Liberdade para escolher minha própria trajetória de carreira é um dos } \\
\text { meus valores mais importantes }\end{array}$ & & 0,628 & & \\
\hline 5 & Estou no comando de minha própria carreira & & 0,776 & & \\
\hline 6 & $\begin{array}{l}\text { No final das contas, dependo de mim mesmo para avançar em minha } \\
\text { carreira }\end{array}$ & & 0,657 & & \\
\hline 7 & No que diz respeito à minha carreira, quem toma as decisões sou eu & & 0,710 & & \\
\hline 9 & $\begin{array}{l}\text { Eu conduzo minha própria carreira, baseado(a) em minhas prioridades } \\
\text { pessoais e não nas prioridades de meu empregador }\end{array}$ & & & & 0,515 \\
\hline 10 & $\begin{array}{l}\text { Não é muito importante para mim a forma com que as pessoas avaliam as } \\
\text { escolhas que eu faço em minha carreira }\end{array}$ & & & & 0,614 \\
\hline 11 & $\begin{array}{l}\text { O que mais importa para mim é como eu me sinto em relação a meu } \\
\text { sucesso na carreira e não como outras pessoas se sentem a respeito disso }\end{array}$ & & & & 0,632 \\
\hline 12 & $\begin{array}{l}\text { Sigo a minha própria consciência se a minha empresa solicitar que eu faça } \\
\text { algo que seja contra os meus valores }\end{array}$ & & & & 0,655 \\
\hline 13 & $\begin{array}{l}\text { O que eu acho que está certo em minha carreira é mais importante para } \\
\text { mim do que o que minha empresa acha }\end{array}$ & & & & 0,740 \\
\hline 14 & $\begin{array}{l}\text { Em minhas experiências passadas, eu segui meus próprios valores mesmo } \\
\text { quando a empresa me pediu para fazer algo com o qual eu não concordava }\end{array}$ & & & & 0,646 \\
\hline 16 & Gostaria de trabalhar em projetos com pessoas de várias organizações & 0,752 & & & \\
\hline 17 & Gosto de tarefas que requeiram que eu trabalhe fora da organização & 0,715 & & & \\
\hline 18 & $\begin{array}{l}\text { Gosto de tarefas em meu trabalho que requeiram que eu trabalhe além do } \\
\text { meu próprio departamento }\end{array}$ & 0,729 & & & \\
\hline 19 & Gosto de trabalhar com pessoas fora da minha organização & 0,861 & & & \\
\hline 20 & $\begin{array}{l}\text { Gosto de trabalhos que requeiram que eu interaja com pessoas de várias } \\
\text { organizações diferentes }\end{array}$ & 0,840 & & & \\
\hline 21 & $\begin{array}{l}\text { No passado, busquei oportunidades que me permitissem trabalhar fora da } \\
\text { organização }\end{array}$ & 0,589 & & & \\
\hline 22 & Sinto-me motivado quando enfrento experiências e situações novas & 0,485 & & & \\
\hline 23 & $\begin{array}{l}\text { Gosto da previsibilidade decorrente de se trabalhar continuamente para a } \\
\text { mesma organização }\end{array}$ & & & 0,611 & \\
\hline
\end{tabular}




\begin{tabular}{|c|c|c|c|c|c|}
\hline $\mathbf{N}^{\circ}$ & Questão & MP & AD & MF & OV \\
\hline 24 & $\begin{array}{l}\text { Eu me sentiria bastante perdido se não pudesse trabalhar para a minha } \\
\text { atual organização }\end{array}$ & & & 0,659 & \\
\hline 25 & $\begin{array}{l}\text { Prefiro permanecer em uma empresa com a qual eu esteja familiarizado } \\
\text { do que procurar por outro emprego em outro lugar }\end{array}$ & & & 0,746 & \\
\hline 26 & $\begin{array}{l}\text { Se minha empresa proporcionasse emprego vitalício, eu nunca iria querer } \\
\text { procurar trabalho em outras organizações }\end{array}$ & & & 0,789 & \\
\hline 27 & O meu ideal de carreira seria trabalhar apenas para uma única organização & & & 0,739 & \\
\hline
\end{tabular}

Considerando a maior consistência interna dos fatores, medida pelo alfa de Cronbach, maior variância total explicada e maiores cargas fatoriais na matriz fatorial, respeitando a teoria, optou-se por excluir as questões 1,8 e 15 para continuidade do estudo. Esse questionário reduzido será novamente testado pela Análise Fatorial Confirmatória antes da realização da análise de agrupamentos.

\subsubsection{Análise Fatorial Confirmatória (AFC)}

A AFC visa confirmar os achados da AFE e assim reforçar a validade do instrumento. Através do software SMART PLS, o modelo estrutural foi definido e a aplicação à base de dados foi analisada. A ilustração 8 mostra as cargas fatoriais dentro do modelo definido.

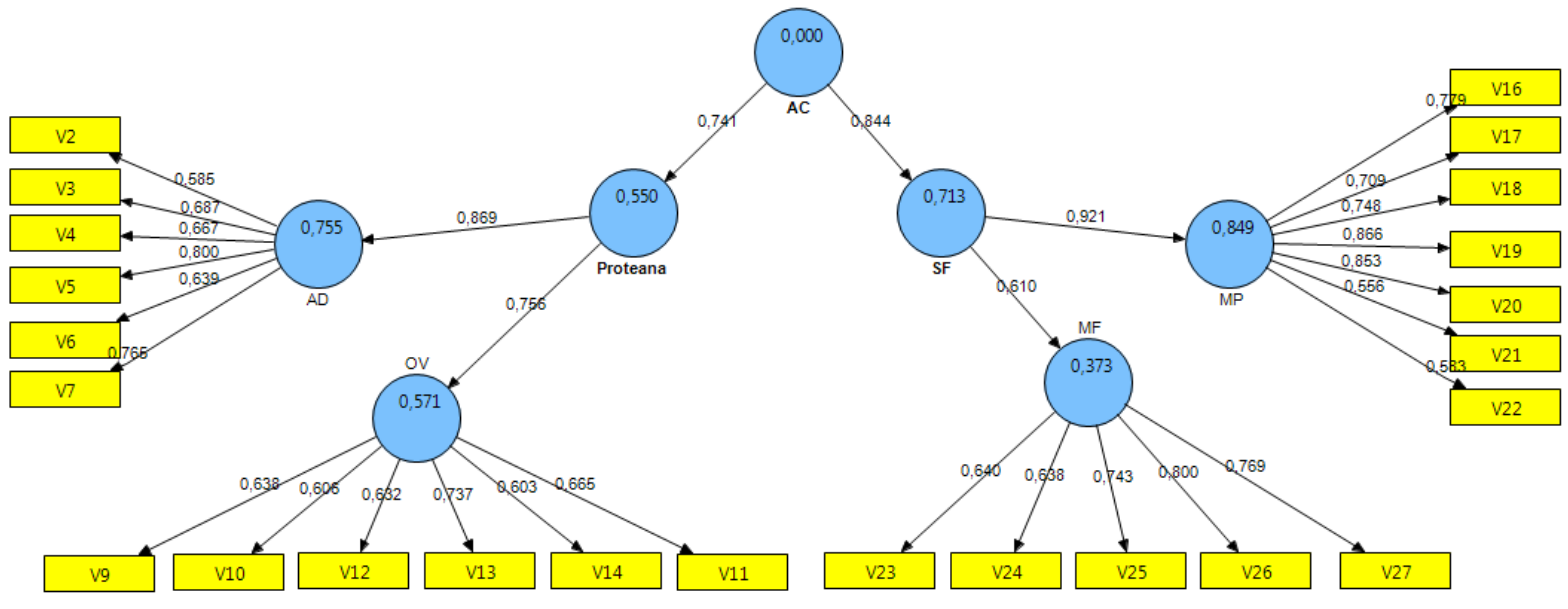

Ilustração 8 - AFC gerada através do software SMART PLS (sem as questões 1, 8 e 15)

Observam-se na ilustração 8 que todos os coeficientes padronizados são superiores a 0,5. Esses coeficientes estão descritos no apêndice 5. 
O resultado indica que o autodirecionamento $\left(\mathrm{R}^{2}=0,755\right.$, representado no centro do círculo) é mais relevante para explicar a carreira proteana do que a orientação pelos valores $\left(\mathrm{R}^{2}=\right.$ 0,571), enquanto a mobilidade psicológica é mais relevante para explicar a carreira sem fronteiras $\left(\mathrm{R}^{2}=0,849\right)$ do que a mobilidade física $\left(\mathrm{R}^{2}=0,373\right)$.

A tabela 15 mostra os resultados de outros critérios de confiabilidade encontrados na AFC. Observa-se que as confiabilidades compostas de todos os fatores são superiores a 0,7 e os alfas de Cronbach são superiores a 0,6, estando acima dos valores mínimos aceitáveis, de acordo com Hair et al (2009), confirmando os resultados satisfatórios encontrados na AFE. A variância extraída (AVE) deveria ser superior a 0,5, no entanto, as duas dimensões da carreira proteana, $\mathrm{AD}$ e $\mathrm{OV}$, estão abaixo desse valor, indicando baixa variância explicada nesses fatores.

Tabela 15 - Resultados dos critérios de confiabilidade da AFC por fator e constructo

\begin{tabular}{|c|c|c|c|}
\hline & Confiabilidade Composta & Alfa de Cronbach & Variância Extraída (AVE) \\
\hline AD & 0,846601 & 0,781888 & 0,481875 \\
\hline OV & 0,812343 & 0,723536 & 0,420297 \\
\hline Proteana & 0,834315 & 0,783661 & 0,300885 \\
\hline MP & 0,890025 & 0,853098 & 0,542089 \\
\hline MF & 0,842827 & 0,76629 & 0,519644 \\
\hline SF & 0,858249 & 0,819386 & 0,348702 \\
\hline
\end{tabular}

A matriz de correlação entre as variáveis latentes (ou fatores analisados), exposta na tabela 16, indica que a maior correlação de cada fator é com a teoria de carreira que o representa, por exemplo, autodirecionamento apresenta maior correlação com a carreira proteana, novamente confirmando o modelo.

Tabela 16 - Matriz de correlação entre os fatores e constructos

\begin{tabular}{|c|c|c|c|c|c|c|}
\hline & AD & OV & MP & MF & Proteana & SF \\
\hline AD & 1,0000 & & & & & \\
\hline OV & 0,3330 & 1,0000 & & & & \\
\hline MP & 0,2631 & 0,1440 & 1,0000 & & & \\
\hline MF & 0,1447 & 0,0575 & 0,2543 & 1,0000 & & \\
\hline Proteana & $\mathbf{0 , 8 6 8 9}$ & $\mathbf{0 , 7 5 5 9}$ & 0,2600 & 0,1318 & 1,0000 & \\
\hline SF & 0,2758 & 0,1417 & $\mathbf{0 , 9 2 1 3}$ & $\mathbf{0 , 6 1 0 3}$ & 0,2677 & 1,0000 \\
\hline
\end{tabular}


As correlações encontradas tem proporções semelhantes às encontradas por Briscoe et al (2006) e Silva (2009). Por exemplo, autodirecionamento apresenta maior correlação com orientação pelos valores e, após isso, com mobilidade psicológica, sendo o fator com maiores cargas de correlação com outros; orientação pelos valores apresenta a menor correlação da matriz com mobilidade física, etc. Esse resultado confirma o achado de Briscoe et al (2006) de que os fatores e os constructos são distintos mas correlacionados.

Para verificar a significância dos coeficientes padronizados foi executado o procedimento de Bootstrapping no SMART PLS com 500 amostras. A ilustração 9 apresenta os valores de $t$ de Student para o modelo.

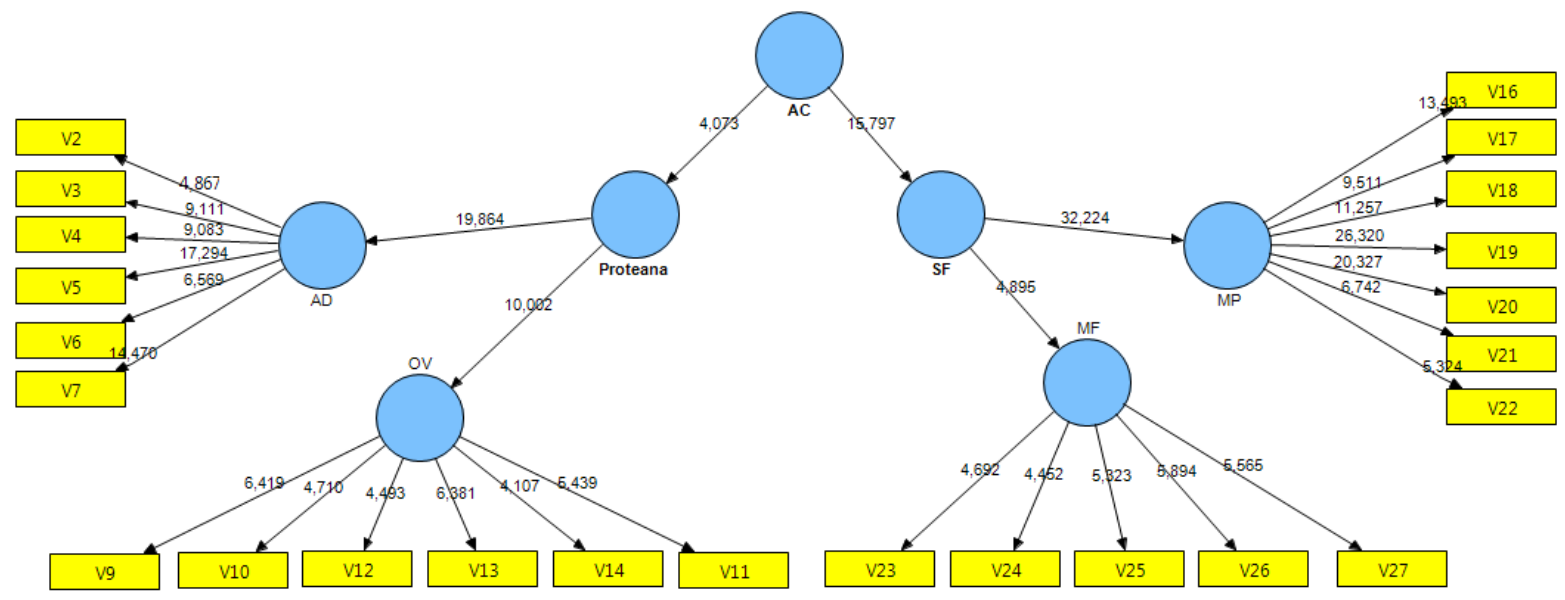

\section{Ilustração 9 - Resultados do Bootstrapping gerado através do software SMART PLS com 500 amostras}

Todos os valores são superiores são superiores a 1,96, portanto, todas as cargas são significantes, representando que há correlações entre as variáveis (perguntas) e as variáveis latentes (dimensões de carreira) e entre estas e as teorias de carreira (proteana e sem fronteiras). Os valores $t$ de student das variáveis estão descritos no apêndice 6 e a tabela 17 apresenta os coeficientes padronizados e $t$ de Student dos fatores gerados na AFC.

Tabela 17 - Coeficientes padronizados e valores $t$ de Student dos fatores de acordo com a AFC

\begin{tabular}{|c|c|c|}
\hline & Coeficientes padronizados & t de Student \\
\hline AD & 0,868911 & 19,863924 \\
\hline OV & 0,755921 & 10,002183 \\
\hline MP & 0,921254 & 32,224437 \\
\hline MF & 0,610347 & 4,894585 \\
\hline
\end{tabular}


Esses resultados indicam convergência no modelo e confirmam a validade da escala de atitude de carreira proteana e sem fronteiras na amostra analisada. Confirmada a validade, segue-se para o segundo objetivo específico, a classificação em perfis de carreira de acordo com as atitudes de carreira.

\subsection{Classificação dos respondentes conforme suas atitudes de carreira}

Após a validação do instrumento, os respondentes foram classificados conforme suas atitudes de carreira. Os agrupamentos foram feitos no SPSS com a técnica não hierárquica $K$-means.

Inicialmente a análise foi feita com 16 sementes, representando todas as combinações de altas e baixas presenças das quatro atitudes de carreira. Os resultados estão expostos na tabela 18.

Tabela 18 - Análise de agrupamento com 16 grupos

\begin{tabular}{|c|c|c|c|c|c|c|c|c|c|c|}
\hline \multirow{2}{*}{ Grupo } & \multicolumn{4}{|c|}{ Centroides } & No de & \multicolumn{3}{|c|}{ Presença das atitudes } & \multirow{2}{*}{ Perfil de } \\
\cline { 8 - 10 } & AD & OV & MP & MF & por grupo & AD & OV & MP & MF & Carreira \\
\hline $\mathbf{1}$ & $-2,39$ & $-1,18$ & $-2,07$ & $-0,93$ & 47 & Baixo & Baixo & Baixo & Baixo & Perdido \\
\hline $\mathbf{2}$ & $-0,30$ & $-0,26$ & $-0,39$ & 0,09 & 234 & Baixo & Baixo & Baixo & Alto & Andarilho \\
\hline $\mathbf{3}$ & $-0,39$ & 0,82 & $-1,68$ & $-0,86$ & 85 & Baixo & Alto & Baixo & Baixo & Seguro \\
\hline $\mathbf{4}$ & $-0,50$ & $-0,64$ & 0,71 & $-1,30$ & 119 & Baixo & Baixo & Alto & Baixo & não definido \\
\hline $\mathbf{5}$ & 0,79 & $-0,48$ & $-1,08$ & $-1,26$ & 96 & Alto & Baixo & Baixo & Baixo & não definido \\
\hline $\mathbf{6}$ & 0,72 & 0,65 & $-0,21$ & $-0,31$ & 187 & Alto & Alto & Baixo & Baixo & não definido \\
\hline $\mathbf{7}$ & $-1,55$ & 0,81 & 0,55 & $-0,87$ & 104 & Baixo & Alto & Alto & Baixo & Idealista \\
\hline $\mathbf{8}$ & 0,68 & $-1,70$ & $-0,66$ & 0,60 & 126 & Alto & Baixo & Baixo & Alto & não definido \\
\hline $\mathbf{9}$ & $-0,96$ & 0,73 & $-0,86$ & 0,96 & 115 & Baixo & Alto & Baixo & Alto & não definido \\
\hline $\mathbf{1 0}$ & $-1,04$ & $-1,34$ & 0,55 & 0,46 & 118 & Baixo & Baixo & Alto & Alto & não definido \\
\hline $\mathbf{1 1}$ & 0,90 & $-1,63$ & 0,75 & $-0,91$ & 92 & Alto & Baixo & Alto & Baixo & Organizacional \\
\hline $\mathbf{1 2}$ & 0,78 & 0,57 & $-1,48$ & 0,78 & 158 & Alto & Alto & Baixo & Alto & não definido \\
\hline $\mathbf{1 3}$ & $-1,20$ & 0,25 & 0,86 & 0,84 & 167 & Baixo & Alto & Alto & Alto & não definido \\
\hline $\mathbf{1 4}$ & 0,59 & 0,81 & 0,67 & $-1,61$ & 155 & Alto & Alto & Alto & Baixo & Cidadão Sólido \\
\hline $\mathbf{1 5}$ & 0,62 & $-0,46$ & 0,61 & 0,69 & 267 & Alto & Baixo & Alto & Alto & Contratado \\
\hline & & & & & & & & & & Arquiteto da \\
$\mathbf{1 6}$ & 0,36 & 0,87 & 0,68 & 0,53 & 306 & Alto & Alto & Alto & Alto & $\begin{array}{c}\text { Carreira } \\
\text { Proteana }\end{array}$ \\
\hline
\end{tabular}

Observa-se que foi possível encontrar os oito perfis definidos pela teoria e também os 8 perfis não descritos por Briscoe e Hall (2006), indicando que outras possibilidades de perfis de carreira podem ser uma realidade prática. 
Esse agrupamento divide de forma significativa a amostra, existindo diversos grupos com um número significativo de indivíduos. Os grupos de maior representatividade são o "Arquiteto da Carreira Proteana" com 306 indivíduos, o "Contratado" com 267 respondentes e o "Andarilho" com 234.

Foram analisados também o resultado de oito grupos, representados pelos perfis descritos como teoricamente mais prováveis. Os resultados estão descritos na tabela 19.

Tabela 19 - Análise de agrupamento com 8 grupos

\begin{tabular}{|c|c|c|c|c|c|c|c|c|c|c|}
\hline \multirow{2}{*}{ Grupo } & \multicolumn{4}{|c|}{ Centroides } & \multirow{2}{*}{$\begin{array}{c}\mathrm{N}^{\mathbf{0}} \text { de } \\
\text { indivíduos } \\
\text { por grupo }\end{array}$} & \multicolumn{4}{|c|}{ Presença das atitudes } & \multirow{2}{*}{$\begin{array}{l}\text { Perfil de } \\
\text { Carreira }\end{array}$} \\
\hline & AD & OV & MP & MF & & AD & OV & MP & MF & \\
\hline 1 & $-2,18$ & $-0,73$ & $-1,54$ & $-0,90$ & 88 & Baixo & Baixo & Baixo & Baixo & Perdido \\
\hline 2 & 0,68 & 0,38 & $-1,53$ & $0,05^{*}$ & 283 & Alto & Alto & Baixo & Neutro & não definido \\
\hline 3 & $-0,58$ & 0,33 & $-0,65$ & 0,49 & 312 & Baixo & Alto & Baixo & Alto & não definido \\
\hline 4 & $-1,32$ & $0,07 *$ & 0,78 & 0,35 & 302 & Baixo & Neutro & Alto & Alto & não definido \\
\hline 5 & 0,31 & $-0,96$ & 0,31 & $-1,12$ & 254 & Alto & Baixo & Alto & Baixo & Organizacional \\
\hline 6 & 0,27 & 0,82 & 0,46 & $-1,44$ & 275 & Alto & Alto & Alto & Baixo & $\begin{array}{l}\text { Cidadão } \\
\text { Sólido }\end{array}$ \\
\hline 7 & 0,41 & $-1,36$ & 0,14 & 0,58 & 324 & Alto & Baixo & Alto & Alto & Contratado \\
\hline 8 & 0,54 & 0,54 & 0,53 & 0,56 & 538 & Alto & Alto & Alto & Alto & $\begin{array}{c}\text { Arquiteto da } \\
\text { Carreira } \\
\text { Proteana } \\
\end{array}$ \\
\hline
\end{tabular}

* Não significante no nível de confiança de 5\% no teste Mann-Whitney

A análise de oito grupos, apesar de utilizar pontos sementes para o agrupamento de acordo com a teoria, encontrou centroides que levaram a identificação de apenas cinco dos oito grupos. Não foram encontrados os perfis "Andarilho", "Seguro" e "Idealista". No entanto, os demais perfis apresentam uma divisão menos proporcional de respondentes, indicando uma solução mais criteriosa. $\mathrm{O}$ perfil com maior número de respondentes se manteve o mesmo, o "Arquiteto da Carreira Proteana", com 538 indivíduos. O perfil com menor número de respondentes também se manteve igual, o "Perdido", com apenas 88 indivíduos compondo esse grupo. Segers et al (2008) encontrou quatro perfis em seu estudo, sendo que três deles são iguais os encontrados nessa análise, os perfis "Perdido", "Contratado" e "Arquiteto da Carreira Proteana".

Foram avaliados agrupamentos com menos de 8 grupos, para observar se os indivíduos migrariam para grupos descritos na teoria. A tabela 20 descreve a solução de 5 grupos gerados somente com as sementes dos cinco perfis encontrados na solução de 8 grupos (Perdido, Organizacional, Cidadão Sólido, Contratado e Arquiteto da Carreira Proteana). 
Tabela 20 - Análise de agrupamento com 5 grupos

\begin{tabular}{|c|c|c|c|c|c|c|c|c|c|c|}
\hline \multirow{2}{*}{ Grupo } & \multicolumn{4}{|c|}{ Centroides } & \multirow{2}{*}{$\begin{array}{c}\mathbf{N}^{\mathbf{0}} \text { de } \\
\text { indivíduos } \\
\text { por grupo }\end{array}$} & \multicolumn{4}{|c|}{ Presença das atitudes } & \multirow{2}{*}{$\begin{array}{l}\text { Perfil de } \\
\text { Carreira }\end{array}$} \\
\hline & $\mathbf{A D}$ & OV & MP & MF & & AD & OV & MP & MF & \\
\hline 1 & $-0,34$ & 0,08 & $-1,72$ & $-0,23$ & 328 & Baixo & Alto & Baixo & Baixo & Seguro \\
\hline 2 & $-1,20$ & 0,20 & 0,48 & 0,34 & 455 & Baixo & Alto & Alto & Alto & não definido \\
\hline 3 & 0,30 & 0,32 & 0,38 & $-1,38$ & 447 & Alto & Alto & Alto & Baixo & Cidadão Sólido \\
\hline 4 & 0,31 & $-1,34$ & 0,22 & 0,24 & 475 & Alto & Baixo & Alto & Alto & Contratado \\
\hline 5 & 0,56 & 0,56 & 0,11 & 0,63 & 671 & Alto & Alto & Alto & Alto & $\begin{array}{c}\text { Arquiteto da } \\
\text { Carreira Proteana }\end{array}$ \\
\hline
\end{tabular}

Observa-se na tabela 20 que a solução de 5 grupos transformou o perfil "Perdido" no perfil "Seguro" devido ao agrupamento de indivíduos com respostas diferentes, o que fez inclusive que a quantidade de pessoas nesse grupo praticamente quadruplicasse. $O$ perfil "Organizacional” não foi encontrado, gerando, a partir da análise dos centroides, uma solução diferente da teoria. Isso indica que o número de grupos é pequeno para reunir indivíduos com perfis diversos afetando os centroides dos grupos gerados. A análise de 6 e 7 grupos gerou resultados semelhantes a esses, ou seja, encontraram-se soluções com menos grupos descritos pela teoria e cujos valores dos centroides eram mais próximos de zero, indicando o agrupamento de indivíduos com resultados diversos.

A análise hierárquica pela técnica de Ward foi realizada para obter-se uma indicação do número de grupos estatisticamente sugerido de acordo com a amostra. A técnica indicou 5 grupos como a solução ideal, baseada na variação da taxa de aglomeração. No entanto, os problemas descritos acima indicam que essa solução não se adéqua ao propósito deste estudo e estabelece uma relação limitada com a teoria estudada. Apesar disso, a solução sugerida pela técnica de Ward contribui para a definição do número de grupos ideal na medida em que ela indica que uma menor quantidade de grupos, próxima de 5 grupos, é preferível a uma maior quantidade de grupos. Ela oferece elementos para a conclusão de que a solução de 8 grupos é preferível a solução de 16 grupos.

Conforme descrito por Hair et al (2009) na aplicação da análise de agrupamentos, o papel do pesquisador é fundamental na escolha da solução mais adequada, amparado pela teoria.

A análise da solução de 16, 8, 7, 6 e 5 grupos indicou a solução de 8 grupos como a mais adequada para atender aos objetivos desse estudo. Essa solução foi eleita pela distribuição 
dos indivíduos dentro dos grupos, que indica maior seletividade, e também pelo maior alinhamento dos perfis predominantes com as teorias de geração e carreiras.

\subsubsection{Análise dos resultados da solução de 8 grupos}

O maior grupo, representado por $23 \%$ dos respondentes é o "Arquiteto da Carreira Proteana" que possui alta presença de todas as atitudes de carreira. Na sequência aparecem três grupos, que representam 13\% dos respondentes válidos: "Contratado" que possui alta presença de todas as dimensões exceto Orientação pelos Valores, "Grupo 3" e "Grupo 4". Os três grupos com maior proporção de altas atitudes de carreira aparecem claramente na análise de agrupamento ("Arquiteto da Carreira Proteana", "Contratado" e "Cidadão Sólido"). O grupo do perfil "Perdido", que tem baixa presença das quatro atitudes é o menor, representado por $4 \%$ dos respondentes válidos.

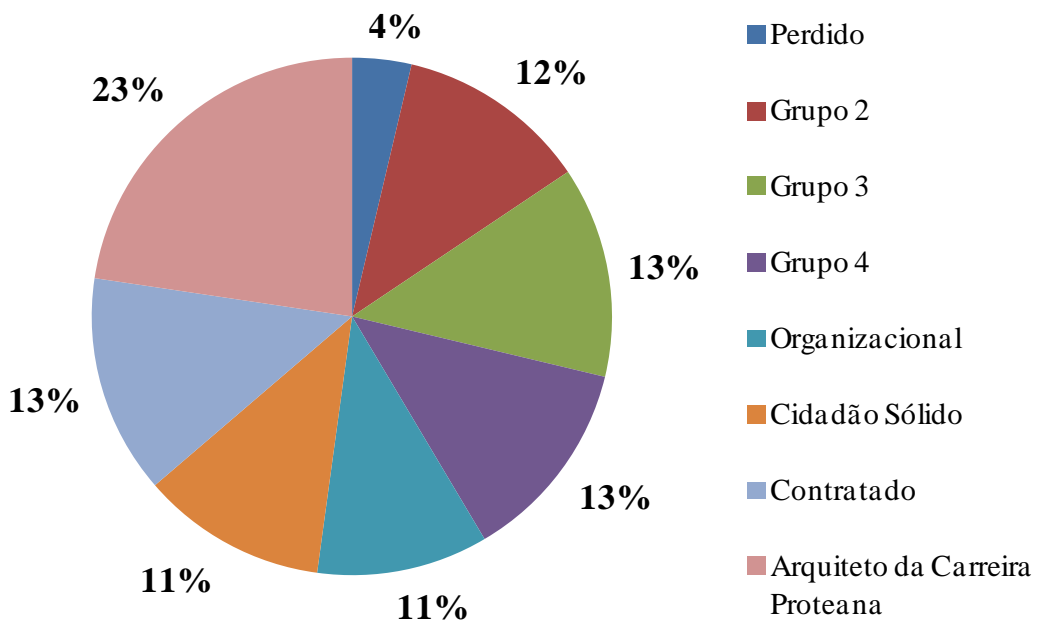

Gráfico 3 - Distribuição dos respondentes entre os 8 perfis de carreira

O gráfico 4 permite a análise visual dos centroides dos 8 grupos. É possível observar que existe uma distinção clara dos centroides para cada perfil. Apenas dois centroides estão muito próximos da neutralidade, Mobilidade Física do Grupo 2 e a Orientação pelos Valores do Grupo 4. A análise da significância estatística desses centroides, pelo método Mann-Whitney, 
indica que eles não podem ser considerados como altos, apesar de serem levemente superiores a zero. Logo, esses pontos serão considerados como neutros para esses perfis.

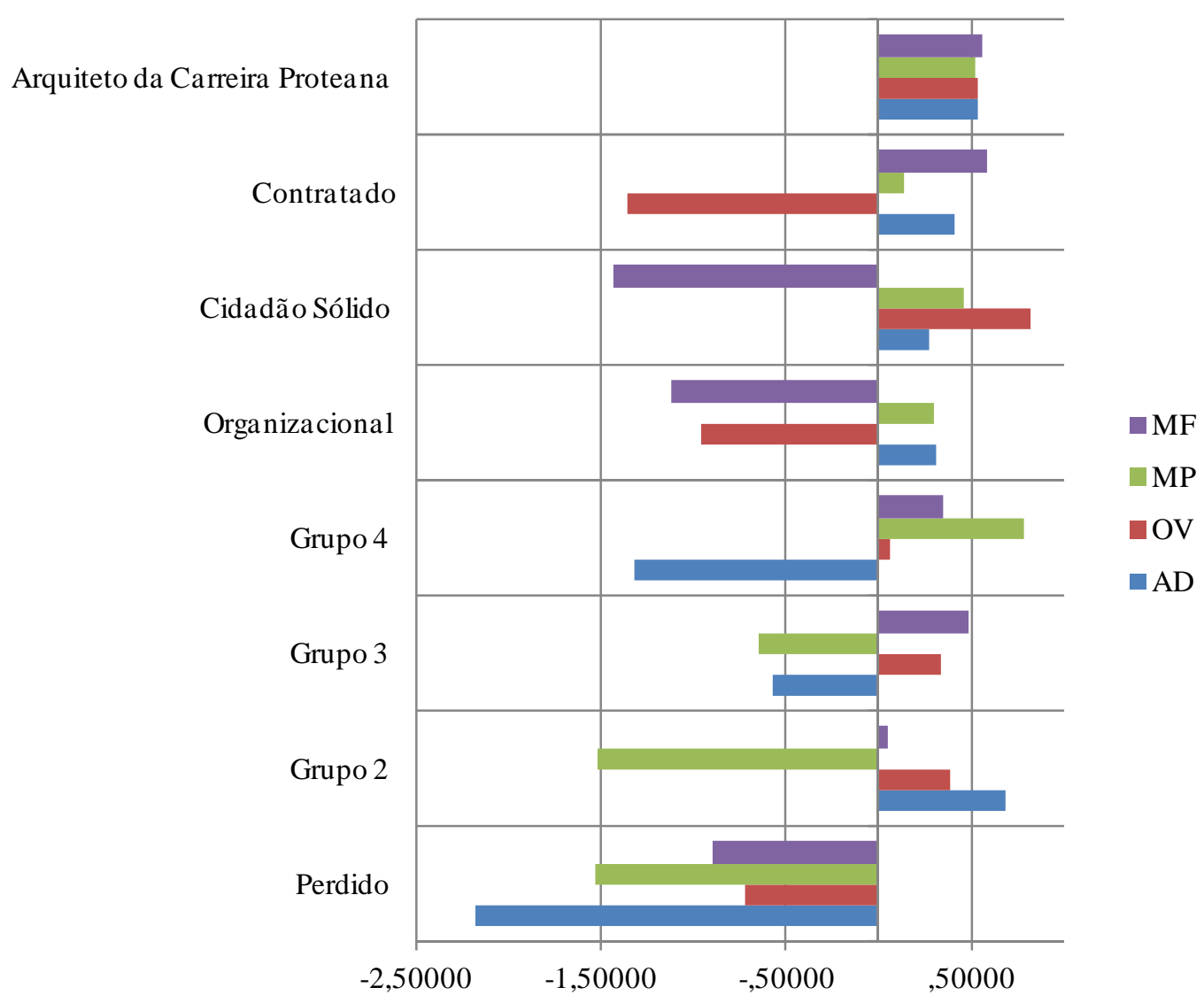

Gráfico 4 - Centroides das dimensões de carreira dos 8 grupos encontrados

Observando os grupos encontrados e a quantidade de indivíduos em cada grupo, descritos no gráfico 3, observa-se que esses resultados estão alinhados com as teorias de carreira e de gerações que indicam que os jovens tem tendência a atitudes de carreira modernas devido a sua socialização dentro desse ambiente sem fronteiras, com um mercado de trabalho mais competitivo, globalizado e caracterizado pelas mudanças e velocidade.

Mesmo os grupos 2, 3 e 4, não definidos na teoria, tem uma alta predominância de carreiras modernas. $\mathrm{O}$ grupo 2 apresenta alto autodirecionamento e orientação pelos valores. O grupo 3 apresenta alta orientação pelos valores e mobilidade física. O grupo 4 apresenta alta mobilidade psicológica e física. 
É interessante notar que mesmo existindo uma predominância dos perfis modernos, ainda existe uma proporção significativa de indivíduos com baixas atitudes de carreira em diversas dimensões, indicando que esse é um movimento e não uma realidade para todos os jovens pesquisados. A análise do impacto das variáveis demográficas sobre os perfis e atitudes de carreira podem indicar alguns influenciadores importantes da presença dessas diferentes atitudes na amostra estudada. Essa análise será feita no final deste capítulo.

A análise dos três perfis encontrados não descritos na teoria será feita a seguir.

\subsubsection{Análise dos perfis encontrados não descritos na teoria}

Apesar de serem usados pontos sementes relacionados com a teoria, o agrupamento estatístico encontrou centroides de 3 grupos que não eram relacionados com os perfis descritos por Briscoe e Hall (2006). Esses 3 grupos serão descritos nessa subseção.

\section{Grupo 2}

Esse grupo apresentou alta presença de autodirecionamento e orientação pelos valores, ou seja, as duas dimensões da carreira proteana, baixa mobilidade psicológica e mobilidade física neutra. 283 indivíduos, ou 12\% da amostra integram esse grupo. Essas pessoas se apresentam como atores de carreira proteana, ou seja, apresentam adaptabilidade, autonomia e autogestão da carreira, sendo direcionadas pelos seus valores ao invés de serem direcionadas pela organização (HALL, 2002).

No entanto, não se apresentam como atores de carreira sem fronteiras, porque buscam estabilidade e continuidade e não demonstram atitude de iniciar ou procurar relacionamentos profissionais além de um único empregador. Isso pode acontecer por não terem conhecimentos e experiências que os permitam transitar em diferentes ambientes ou por não possuírem qualificação para fazer esse movimento (SULLIVAN; ARTHUR, 2006).

Um elemento interessante desse perfil é a neutralidade da mobilidade física, ou seja, esses indivíduos estão no limiar entre o movimento e a inércia entre os limites de organizações. Provavelmente a baixa mobilidade psicológica faz com que os movimentos físicos sejam mais 
raros, mas a orientação proteana pode fazer com que eles aconteçam se o ator de carreira julgar necessário para o seu desenvolvimento profissional ou para manter o alinhamento com seus valores.

Devido a essas características esse grupo foi nomeado "Proteano estável".

\section{Grupo 3}

É composto por indivíduos com baixo autodirecionamento, alta orientação pelos valores, baixa mobilidade psicológica e alta mobilidade física. É o terceiro maior grupo da amostra com 312 pessoas, representando 13\% do total. Esse grupo apresenta um misto entre a carreira proteana e sem fronteiras na medida em que apresenta uma dimensão de cada constructo.

Observa-se que suas características marcantes são a orientação pelos valores e a mobilidade física, indicando que seus valores pessoais funcionam como bússola para a tomada de decisão e que os movimentos entre as fronteiras acontecem com facilidade. No entanto, esses indivíduos não tem um gerenciamento ativo de suas carreiras, não reconhecendo seu papel de protagonista em suas carreiras, provavelmente atribuindo essa função a terceiros, a organizações ou ao mercado de trabalho.

A baixa mobilidade psicológica associada à alta mobilidade física indica que esses indivíduos estão dispostos a mudanças físicas de local de trabalho ou organização por motivos pessoais, mas que buscam continuidade e similaridade entre essas diferentes ocupações (SULLIVAN; ARTHUR, 2006). A falta de mobilidade psicológica gera uma busca por atividades e funções semelhantes que não necessitem de grande esforço de adaptação ou mudança.

Concluindo, são indivíduos que tem baixo gerenciamento de suas carreiras e buscam posições e atividades semelhantes que os poupem de grandes esforços de adaptação, mas por outro lado, buscam alinhamento a seus valores pessoas e se movimentam fisicamente com facilidade, se julgam interessante ou necessário.

Por essas características, esse grupo foi chamado de "Viajante orientado", "viajante" devido a sua alta mobilidade física e "orientado" devido a sua orientação pelos valores e busca de opções semelhantes que não exijam o esforço de adaptação. A palavra "orientado" também 
remete a um direcionamento, mas sem a visão de controle ou gestão, já que esse perfil também apresenta baixo autodirecionamento da carreira.

\section{Grupo 4}

Esse grupo apresenta baixo autodirecionamento, orientação pelos valores neutra, alta mobilidade psicológica e alta mobilidade física. É composto por 302 pessoas, sendo responsável por $13 \%$ da amostra. É um grupo sem fronteiras, já que apresenta alta presença das duas dimensões desse constructo, mas é um grupo com pouca orientação proteana.

Sullivan e Arthur (2006) indicam que pessoas com altas atitudes sem fronteiras apresentam muitas mudanças físicas enquanto mudam sua orientação psicológica de carreira frequentemente, tais como, indivíduos que mudam de emprego e buscam oportunidades de aprendizado e desafios ou buscam atender necessidades pessoais ou familiares. Eles têm um grande nível de flexibilidade e capacidade de adaptação. É possível que suas escolhas possam fazer sentido apenas para o ator de carreira em sua busca de autonomia, equilíbrio entre vida pessoal e trabalho, desenvolvimento, etc.

Analisando as dimensões da carreira proteana nesse grupo, observa-se que o baixo autodirecionamento indica que esses indivíduos não apresentam um gerenciamento ativo de suas carreiras. Além disso, apresentam uma neutralidade em sua orientação pelos valores, sugerindo que algumas decisões são orientadas pelos valores pessoais e outras não. Essas decisões não orientadas pelos valores podem ser direcionadas por elementos externos, tais como, o empregador, colegas, familiares, etc. É provável que um desses elementos externos seja um grande influenciador desse ator de carreira, funcionando inclusive como modelos.

Esse perfil faz sentido em uma amostra de jovens que estão em uma caminhada de autoconhecimento e reflexão sobre seus valores pessoais, sendo influenciados pelo sucesso objetivo e por terceiros em suas decisões, mas com grande facilidade em movimentar-se física e psicologicamente.

Observando o desenvolvimento da orientação pelos valores, descrita por Sargent e Domberger (2007), esses jovens podem estar em um momento de teste de seus valores relacionados ao trabalho, advindos de modelos como os pais, colegas e pares. A experiência prática de 
trabalho provê o espaço de experimentação necessário para a confirmação ou rejeição dos valores emergentes. O resultado desse processo é a confirmação dos valores pessoais que serão utilizados no futuro, com base nas preferências pessoais do ator.

Considerando essa descrição, esse perfil foi denominado "Buscador", que sugere esse movimento contínuo e o amplo espaço que esse indivíduo possui para ampliar seu autoconhecimento, identificar o papel dos valores em sua vida e reconhecer seu protagonismo em relação a sua carreira.

\subsection{Análise da influência das características demográficas e profissionais nas atitudes e perfis de carreira}

Antes da análise da associação entre os agrupamentos obtidos e as características demográficas dos indivíduos que fazem parte desses grupos, optou-se pela análise inicial da influência das características demográficas e profissionais nas atitudes de carreira modernas. Como os perfis são compostos pelas combinações de alta ou baixa presença das atitudes de carreira, a análise inicial da associação entre as atitudes e a demografia é importante para aprofundamento da compreensão da influência dessas variáveis no perfil de carreira.

A análise da associação tanto das atitudes de carreira quanto dos perfis encontrados com as características demográficas foi feita através de testes Qui-Quadrado, buscando identificar quais variáveis eram estatisticamente significantes para diferenciar esses grupos.

Para obter o número mínimo de 5 observações em cada célula de frequência esperada, algumas variáveis foram agrupadas, tais como, ano de nascimento (de 1982 à 1985, de 1986 à 1989 e de 1990 à 1994), escolaridade (agrupamento de "ensino fundamental" com "ensino médio"), estado civil (agrupamento de "casado/união estável" com "divorciado/separado"), filhos (agrupamento de "1 filho", com "2 filhos" e com "3 ou mais filhos"), estado/cidade (agrupamento em Norte, Nordeste e Centro Oeste, Sul, Minas Gerais e Espírito Santo, Rio de Janeiro, São Paulo - Capital e São Paulo - Interior), cargo (agrupamento de "outros" com "sem experiência"), número de empregadores (agrupamento de 0 com 1 empregadores e agrupamento de 6 com 7 ou mais empregadores). 
Essa seção é dividida em duas, sendo que a primeira subseção apresenta os resultados da associação entre atitudes de carreira e a demografia investigada e a segunda subseção apresenta os resultados da análise da associação entre perfis de carreira e a demografia.

\subsubsection{Análise da influência das características demográficas e profissionais nas atitudes de carreira}

Para análise da relação entre a presença das atitudes de carreira e as variáveis demográficas, cada indivíduo foi classificado como tendo uma alta ou baixa atitude, atribuída de acordo com seus coeficientes gerados na análise fatorial. Indivíduos com resultados acima de zero em um determinado fator ou atitude de carreira foram classificados como tendo uma alta atitude naquele fator e, consequentemente, indivíduos com resultados abaixo de zero em um determinado fator ou atitude de carreira foram classificados como tendo uma baixa atitude no fator.

A partir dessa classificação, foram feitos os testes Qui-Quadrado comparando as frequências reais e esperadas da alta e baixa presença de cada atitude de carreira com cada uma das características demográficas estudadas.

A tabela 21 indica os resultados do valor-p da associação entre as atitudes de carreira e as variáveis demográficas, sendo que resultados do valor-p iguais ou menores de $5 \%$ indicam que a variável demográfica apresenta uma diferença estatisticamente significativa do grupo em questão em relação ao resto da amostra. Os valores significativos estão pintados em laranja para facilitar a visualização.

Tabela 21 - Resultados dos valores-p gerados pelo teste Qui-Quadrado analisando a associação entre as atitudes de carreira e variáveis demográficas

\begin{tabular}{|l|c|c|c|c|}
\hline & AD & OV & MP & MF \\
\hline Ano de Nascimento & $33 \%$ & $41 \%$ & $34 \%$ & $0 \%$ \\
\hline Gênero & $17 \%$ & $43 \%$ & $55 \%$ & $4 \%$ \\
\hline Escolaridade & $80 \%$ & $68 \%$ & $1 \%$ & $0 \%$ \\
\hline Estado Civil & $1 \%$ & $24 \%$ & $92 \%$ & $41 \%$ \\
\hline Filhos & $83 \%$ & $96 \%$ & $83 \%$ & $79 \%$ \\
\hline Renda Individual & $0 \%$ & $47 \%$ & $0 \%$ & $0 \%$ \\
\hline Renda Familiar & $18 \%$ & $54 \%$ & $0 \%$ & $0 \%$ \\
\hline
\end{tabular}




\begin{tabular}{|l|c|c|c|c|}
\hline & AD & OV & MP & MF \\
\hline Estado/Cidade & $95 \%$ & $2 \%$ & $39 \%$ & $74 \%$ \\
\hline Tempo de uso da Internet & $82 \%$ & $10 \%$ & $5 \%$ & $68 \%$ \\
\hline Trabalha atualmente & $88 \%$ & $47 \%$ & $99 \%$ & $67 \%$ \\
\hline Anos de Experiência Profissional & $21 \%$ & $1 \%$ & $4 \%$ & $70 \%$ \\
\hline Cargo & $0 \%$ & $18 \%$ & $2 \%$ & $99 \%$ \\
\hline Número de empregadores & $19 \%$ & $23 \%$ & $50 \%$ & $3 \%$ \\
\hline
\end{tabular}

Abaixo serão apresentadas somente as análises de frequência geradas pelo teste Qui-Quadrado das variáveis significantes para cada atitude de carreira.

\section{Autodirecionamento}

Observa-se na tabela 22 a associação entre estado civil e a presença de autodirecionamento. A frequência de indivíduos solteiros é maior no grupo de pessoas de alto autodirecionamento $(85,4 \%)$ do que no grupo de pessoas de baixo autodirecionamento $(81,4 \%)$.

Tabela 22 - Tabulação cruzada: autodirecionamento e estado civil

\begin{tabular}{|c|c|c|c|c|}
\hline \multicolumn{2}{|c|}{ Estado Civil } & Alta AD & Baixa AD & Total \\
\hline \multirow{2}{*}{ Solteiro } & Frequência & 1132 & 856 & 1988 \\
\cline { 2 - 5 } & $\%$ & $85,4 \%$ & $81,4 \%$ & $83,7 \%$ \\
\hline \multirow{2}{*}{ Casado/União } & Frequência & 193 & 195 & 388 \\
\cline { 2 - 5 } Estável / Divorciado & $\%$ & $14,6 \%$ & $18,6 \%$ & $16,3 \%$ \\
\hline \multirow{2}{*}{ Total } & Frequência & 1325 & 1051 & 2376 \\
\cline { 2 - 5 } & $\%$ & $100,0 \%$ & $100,0 \%$ & $100,0 \%$ \\
\hline
\end{tabular}

Nota-se na tabela 23 que entre os indivíduos com alto autodirecionamento, observa-se menor proporção de pessoas sem rendimento individual $(4,3 \%)$ e maior proporção de pessoas com rendimento individual superior a 5 salários mínimos (19,8\%), quando comparado ao grupo de pessoas com baixo autodirecionamento $(16,9 \%)$.

Tabela 23 - Tabulação cruzada: autodirecionamento e renda individual

\begin{tabular}{|c|c|c|c|c|}
\hline \multicolumn{2}{|c|}{ Renda Média Individual } & Alta AD & Baixa AD & Total \\
\hline \multirow{2}{*}{ Sem rendimento } & Frequência & 57 & 73 & 130 \\
\cline { 2 - 5 } & $\%$ & $\mathbf{4 , 3 \%}$ & $\mathbf{6 , 9 \%}$ & $5,5 \%$ \\
\hline \multirow{2}{*}{ Até R\$ 622,00 } & Frequência & 105 & 69 & 174 \\
\cline { 2 - 5 } & $\%$ & $\mathbf{7 , 9 \%}$ & $\mathbf{6 , 6 \%}$ & $7,3 \%$ \\
\hline \multirow{2}{*}{ entre R\$ 622,00 e R\$ 1.244,00 } & Frequência & 390 & 303 & 693 \\
\cline { 2 - 5 } & $\%$ & $\mathbf{2 9 , 4 \%}$ & $\mathbf{2 8 , 8 \%}$ & $29,2 \%$ \\
\hline
\end{tabular}




\begin{tabular}{|c|c|c|c|c|}
\hline \multicolumn{2}{|c|}{ Renda Média Individual } & Alta AD & Baixa AD & Total \\
\hline entre R\$ 1.244,00 e R\$ & Frequência & 250 & 222 & 472 \\
\cline { 2 - 5 } $\mathbf{1 . 8 6 6 , 0 0}$ & $\%$ & $\mathbf{1 8 , 9 \%}$ & $\mathbf{2 1 , 1 \%}$ & $19,9 \%$ \\
\hline entre R\$ 1.866,00 e R\$ & Frequência & 261 & 206 & 467 \\
\cline { 2 - 5 } $\mathbf{3 . 1 1 0 , 0 0}$ & $\%$ & $19,7 \%$ & $19,6 \%$ & $19,7 \%$ \\
\hline entre R\$ 3.110,00 e R\$ & Frequência & 216 & 163 & 379 \\
\cline { 2 - 5 } M.220,00 & $\%$ & $\mathbf{1 6 , 3 \%}$ & $\mathbf{1 5 , 5 \%}$ & $16,0 \%$ \\
\hline \multirow{2}{*}{ Mais de R\$ 6.220,00 } & Frequência & 46 & 15 & 61 \\
\cline { 2 - 5 } & $\%$ & $\mathbf{3 , 5 \%}$ & $\mathbf{1 , 4 \%}$ & $2,6 \%$ \\
\hline \multirow{2}{*}{ Total } & Frequência & 1325 & 1051 & 2376 \\
\cline { 2 - 5 } & $\%$ & $100,0 \%$ & $100,0 \%$ & $100,0 \%$ \\
\hline
\end{tabular}

As pessoas da amostra com alto autodirecionamento tem maior frequência de ocupação de posições de liderança $(16,8 \%)$ do que as pessoas com baixo autodirecionamento $(12,6 \%)$ e ocupam com menor frequência posições de analista, auxiliar ou assistente $(47,2 \%)$ do que as pessoas com baixa atitude $(54,6 \%)$.

Tabela 24 - Tabulação cruzada: autodirecionamento e cargo

\begin{tabular}{|c|c|c|c|c|}
\hline \multicolumn{2}{|l|}{ Cargo } & Alta AD & Baixa AD & Total \\
\hline \multirow{2}{*}{ Diretor / Gerente } & Frequência & 53 & 19 & 72 \\
\hline & $\%$ & $4,0 \%$ & $1,8 \%$ & $3,0 \%$ \\
\hline \multirow{2}{*}{$\begin{array}{c}\text { Coordenador / Supervisor / } \\
\text { Consultor }\end{array}$} & Frequência & 170 & 114 & 284 \\
\hline & $\%$ & $12,8 \%$ & $10,8 \%$ & $12,0 \%$ \\
\hline \multirow{2}{*}{ Analista / Auxiliar / Assistente } & Frequência & 625 & 574 & 1199 \\
\hline & $\%$ & $47,2 \%$ & $54,6 \%$ & $50,5 \%$ \\
\hline \multirow{2}{*}{ Trainee } & Frequência & 76 & 50 & 126 \\
\hline & $\%$ & $5,7 \%$ & $4,8 \%$ & $5,3 \%$ \\
\hline \multirow{2}{*}{ Estagiário } & Frequência & 239 & 184 & 423 \\
\hline & $\%$ & $18,0 \%$ & $17,5 \%$ & $17,8 \%$ \\
\hline \multirow{2}{*}{ Outro } & Frequência & 162 & 110 & 272 \\
\hline & $\%$ & $12,2 \%$ & $10,5 \%$ & $11,4 \%$ \\
\hline \multirow{2}{*}{ Total } & Frequência & 1325 & 1051 & 2376 \\
\hline & $\%$ & $100,0 \%$ & $100,0 \%$ & $100,0 \%$ \\
\hline
\end{tabular}

Conclui-se que a alta presença de autodirecionamento é mais frequente em indivíduos solteiros, de alta renda individual e de cargos de níveis mais altos. A maior renda e o fato de serem solteiros reforçam a independência do indivíduo e permitem uma autogestão mais flexível de sua carreira. A maior presença de indivíduos em posições de liderança pode ser interpretada como causa ou como consequência do autodirecionamento da carreira.

Segers et al (2008) encontraram uma relação positiva entre autodirecionamento e escolaridade e anos de experiência profissional. Essas relações não foram encontradas na amostra analisada. 


\section{Orientação pelos Valores}

Existe uma maior proporção de indivíduos com alta orientação pelos valores residindo em São Paulo - Capital $(28,6 \%)$ do que de indivíduos com baixa orientação pelos valores $(22,8 \%)$, conforme indica a tabela 25. Esses indivíduos com baixa orientação pelos valores estão mais presentes no Norte, Nordeste e Centro (17,3\%) e no interior do estado de São Paulo (23,3\%). As grandes cidades, como São Paulo, foram identificadas por Ribeiro et al (2009) como mais propícias ao desenvolvimento da carreira proteana, justamente por suas condições de emprego, acesso a educação, saúde, etc.

Tabela 25 - Tabulação cruzada: orientação pelos valores e estado/cidade de residência

\begin{tabular}{|c|c|c|c|c|}
\hline \multicolumn{2}{|l|}{ Estado/Cidade } & Alta OV & Baixa OV & Total \\
\hline \multirow{2}{*}{$\begin{array}{c}\text { Norte / Nordeste / Centro } \\
\text { Oeste }\end{array}$} & Frequência & 190 & 189 & 379 \\
\hline & $\%$ & $14,8 \%$ & $17,3 \%$ & $16,0 \%$ \\
\hline \multirow{2}{*}{ Sul } & Frequência & 153 & 122 & 275 \\
\hline & $\%$ & $11,9 \%$ & $11,2 \%$ & $11,6 \%$ \\
\hline \multirow{2}{*}{ Minas Gerais e Espírito Santo } & Frequência & 144 & 139 & 283 \\
\hline & $\%$ & $11,2 \%$ & $12,7 \%$ & $11,9 \%$ \\
\hline \multirow{2}{*}{ Rio de Janeiro } & Frequência & 130 & 108 & 238 \\
\hline & $\%$ & $10,1 \%$ & $9,9 \%$ & $10,0 \%$ \\
\hline \multirow{2}{*}{ São Paulo - Capital } & Frequência & 367 & 249 & 616 \\
\hline & $\%$ & $28,6 \%$ & $22,8 \%$ & $25,9 \%$ \\
\hline \multirow{2}{*}{ São Paulo - Interior } & Frequência & 299 & 286 & 585 \\
\hline & $\%$ & $23,3 \%$ & $26,2 \%$ & $24,6 \%$ \\
\hline \multirow{2}{*}{ Total } & Frequência & 1283 & 1093 & 2376 \\
\hline & $\%$ & $100,0 \%$ & $100,0 \%$ & $100,0 \%$ \\
\hline
\end{tabular}

Analisando a tabela 26, nota-se que as diferenças entre a alta orientação pelos valores e baixa orientação pelos valores se alterna nas faixas. Ao somarmos essas faixas, observamos que existe maior proporção de indivíduos com alta orientação pelos valores com experiência profissional entre 1 e 3 anos $(35,2 \%)$ do que indivíduos com baixa orientação pelos valores $(31,3 \%)$. O inverso também é verdadeiro, de forma que existe menor proporção de indivíduos com experiência profissional superior a 5 anos no grupo de alta orientação pelos valores $(37,8 \%)$ do que no grupo de indivíduos com baixa orientação pelos valores $(39,1 \%)$.

Tabela 26 - Tabulação cruzada: orientação pelos valores e anos de experiência profissional

\begin{tabular}{|c|c|c|c|c|}
\hline \multicolumn{2}{|c|}{ Anos de Experiência Profissional } & Alta OV & Baixa OV & Total \\
\hline \multirow{2}{*}{ Entre 1 e 2 anos } & Frequência & 203 & 184 & 387 \\
\cline { 2 - 5 } & $\%$ & $\mathbf{1 5 , 8 \%}$ & $\mathbf{1 6 , 8 \%}$ & $16,3 \%$ \\
\hline Entre 2 e 3 anos & Frequência & 249 & 158 & 407 \\
\hline
\end{tabular}




\begin{tabular}{|c|c|c|c|c|}
\hline \multicolumn{2}{|c|}{ Anos de Experiência Profissional } & Alta OV & Baixa OV & Total \\
\hline \multirow{2}{*}{ Entre 3 e 5 anos } & $\%$ & $\mathbf{1 9 , 4 \%}$ & $\mathbf{1 4 , 5 \%}$ & $17,1 \%$ \\
\hline \multirow{2}{*}{ Entre 5 e 7 anos } & Frequência & 346 & 324 & 670 \\
\cline { 2 - 5 } & $\%$ & $27,0 \%$ & $29,6 \%$ & $28,2 \%$ \\
\hline \multirow{2}{*}{ Mais de 7 anos } & Frequência & 277 & 224 & 501 \\
\cline { 2 - 5 } & $\%$ & $\mathbf{2 1 , 6 \%}$ & $\mathbf{2 0 , 5 \%}$ & $21,1 \%$ \\
\hline \multirow{2}{*}{ Total } & Frequência & 208 & 203 & 411 \\
\cline { 2 - 5 } & $\%$ & $\mathbf{1 6 , 2 \%}$ & $\mathbf{1 8 , 6 \%}$ & $17,3 \%$ \\
\hline \multirow{2}{*}{} & Frequência & 1283 & 1093 & 2376 \\
\cline { 2 - 5 } & $\%$ & $100,0 \%$ & $100,0 \%$ & $100,0 \%$ \\
\hline
\end{tabular}

Conclui-se que a alta presença de orientação pelos valores é mais frequente em indivíduos residentes na cidade de São Paulo e com menor experiência profissional.

É interessante notar a associação inversa entre orientação pelos valores e tempo de experiência profissional. Esse resultado pode ser observado tendo como base o modelo de desenvolvimento da carreira proteana proposto por Sargent e Domberger (2007). As experiências profissionais trazem uma possibilidade de testar os valores colocados pelos familiares, colegas e pares no início da carreira, mas essas experiências também podem gerar situações de conflito entre os valores e a continuidade dos planos de carreira. O ator de carreira proteana deveria rever seus planos, preservando seus valores como prioridade, conforme descreve o modelo proposto pelos pesquisadores.

Os resultados da presente pesquisa proporciona o desenvolvimento de uma hipótese alternativa: que o ator pode priorizar seus objetivos de carreira em detrimento de seus valores pessoais, reduzindo a orientação pelos valores como bússola para a tomada de decisão e finalmente reduzindo por consequência sua orientação proteana. Isso explicaria o fato de pessoas com alta orientação pelos valores terem menor experiência profissional e pessoas de baixa orientação pelos valores terem grande experiência profissional na amostra analisada.

Com a perda dos valores como bússola para a tomada das decisões na carreira, o apoio para a tomada de decisões passa a ser firmado em elementos externos, podendo gerar soluções inadequadas ou que não tragam a percepção de sucesso para o ator de carreira.

Segers et al (2008) encontraram uma relação inversa entre orientação pelos valores e escolaridade. Os autores não conseguiram justificar esse achado. Briscoe et al (2006) 
encontraram uma relação inversa entre orientação pelos valores e número de empregadores. Essas associações não foram encontradas nesse estudo.

\section{Mobilidade Psicológica}

Existe uma associação positiva entre escolaridade e mobilidade psicológica. A proporção de indivíduos com pós-graduação é superior entre aqueles que têm alta mobilidade psicológica $(22,7 \%)$ do que entre aqueles que têm baixa mobilidade psicológica $(19,2 \%)$.

Tabela 27 - Tabulação cruzada: mobilidade psicológica e escolaridade

\begin{tabular}{|c|c|c|c|c|}
\hline \multicolumn{2}{|c|}{ Escolaridade } & Alta MP & Baixa MP & Total \\
\hline \multirow{2}{*}{$\begin{array}{c}\text { Ensino Fundamental / } \\
\text { Médio }\end{array}$} & Frequência & 88 & 102 & 190 \\
\hline & $\%$ & $6,7 \%$ & $9,6 \%$ & $8,0 \%$ \\
\hline \multirow{2}{*}{ Ensino Superior } & Frequência & 924 & 759 & 1683 \\
\hline & $\%$ & $70,5 \%$ & $71,2 \%$ & $70,8 \%$ \\
\hline \multirow[t]{2}{*}{ Pós-Graduação } & Frequência & 298 & 205 & 503 \\
\hline & $\%$ & $22,7 \%$ & $19,2 \%$ & $21,2 \%$ \\
\hline \multirow[t]{2}{*}{ Total } & Frequência & 1310 & 1066 & 2376 \\
\hline & $\%$ & $100,0 \%$ & $100,0 \%$ & $100,0 \%$ \\
\hline
\end{tabular}

Observa-se na tabela 28 que existe uma associação positiva entre renda e mobilidade psicológica. $62,6 \%$ dos indivíduos com alta mobilidade psicológica tem renda individual superior a 2 salários mínimos, enquanto $52,4 \%$ das pessoas com baixa mobilidade psicológica tem esse nível de renda. A tabela 29 indica que a mesma associação ocorre em relação à renda familiar. $78,4 \%$ dos indivíduos com alta mobilidade psicológica tem renda familiar superior a 4 salários mínimos, enquanto $70,8 \%$ das pessoas com baixa mobilidade psicológica tem esse nível de renda.

Tabela 28 - Tabulação cruzada: mobilidade psicológica e renda individual

\begin{tabular}{|c|c|c|c|c|}
\hline \multicolumn{2}{|c|}{ Renda Média Individual } & Alta MP & Baixa MP & Total \\
\hline \multirow{2}{*}{ Sem rendimento } & Frequência & 71 & 59 & 130 \\
\cline { 2 - 5 } & $\%$ & $5,4 \%$ & $5,5 \%$ & $5,5 \%$ \\
\hline \multirow{2}{*}{ Até R\$ 622,00 } & Frequência & 89 & 85 & 174 \\
\cline { 2 - 5 } & $\%$ & $6,8 \%$ & $8,0 \%$ & $7,3 \%$ \\
\hline \multirow{2}{*}{ entre R\$ 622,00 e R\$ 1.244,00 } & Frequência & 330 & 363 & 693 \\
\cline { 2 - 5 } & $\%$ & $25,2 \%$ & $34,1 \%$ & $29,2 \%$ \\
\hline entre R\$ 1.244,00 e R\$ & Frequência & 284 & 188 & 472 \\
\hline
\end{tabular}




\begin{tabular}{|c|c|c|c|c|}
\hline \multicolumn{2}{|c|}{ Renda Média Individual } & \multirow{2}{*}{$\begin{array}{c}\text { Alta MP } \\
21,7 \%\end{array}$} & \multirow{2}{*}{$\frac{\text { Baixa MP }}{17,6 \%}$} & \multirow{2}{*}{\begin{tabular}{r|} 
Total \\
$19,9 \%$
\end{tabular}} \\
\hline $1.866,00$ & $\%$ & & & \\
\hline \multirow{2}{*}{$\begin{array}{c}\text { entre } R \$ 1.866,00 \text { e } R \$ \\
3.110,00\end{array}$} & Frequência & 283 & 184 & 467 \\
\hline & $\%$ & $21,6 \%$ & $17,3 \%$ & $19,7 \%$ \\
\hline \multirow{2}{*}{$\begin{array}{c}\text { entre } R \$ 3.110,00 \text { e } R \$ \\
6.220,00\end{array}$} & Frequência & 227 & 152 & 379 \\
\hline & $\%$ & $17,3 \%$ & $14,3 \%$ & $16,0 \%$ \\
\hline \multirow{2}{*}{ Mais de $R \$ 6.220,00$} & Frequência & 26 & 35 & 61 \\
\hline & $\%$ & $2,0 \%$ & $3,3 \%$ & $2,6 \%$ \\
\hline \multirow{2}{*}{ Total } & Frequência & 1310 & 1066 & 2376 \\
\hline & $\%$ & $100,0 \%$ & $100,0 \%$ & $100,0 \%$ \\
\hline
\end{tabular}

Tabela 29 - Tabulação cruzada: mobilidade psicológica e renda familiar

\begin{tabular}{|c|c|c|c|c|}
\hline \multicolumn{2}{|c|}{ Renda Média Familiar } & Alta MP & Baixa MP & Total \\
\hline \multirow{2}{*}{ Até R\$ 1.244,00 } & Frequência & 90 & 87 & 177 \\
\cline { 2 - 4 } & $\%$ & $6,9 \%$ & $8,2 \%$ & $7,4 \%$ \\
\hline entre R\$ 1.244,00 e R\$ & Frequência & 193 & 224 & 417 \\
\cline { 2 - 5 } $\mathbf{2 . 4 8 8 , 0 0}$ & $\%$ & $14,7 \%$ & $21,0 \%$ & $17,6 \%$ \\
\hline entre R\$ 2.448,00 e R\$ & Frequência & 552 & 397 & 949 \\
\cline { 2 - 5 } $\mathbf{6 . 2 2 0 , 0 0}$ & $\%$ & $\mathbf{4 2 , 1 \%}$ & $\mathbf{3 7 , 2 \%}$ & $39,9 \%$ \\
\hline $\begin{array}{c}\text { entre R\$ 6.220,00 e R\$ } \\
\mathbf{1 2 . 4 4 0 , 0 0}\end{array}$ & Frequência & 306 & 220 & 526 \\
\cline { 2 - 5 } Mais de R\$ 12.440 & $\%$ & $\mathbf{2 3 , 4 \%}$ & $\mathbf{2 0 , 6 \%}$ & $22,1 \%$ \\
\cline { 2 - 5 } & Frequência & 169 & 138 & 307 \\
\hline \multirow{2}{*}{ Total } & $\%$ & $12,9 \%$ & $12,9 \%$ & $12,9 \%$ \\
\cline { 2 - 5 } & Frequência & 1310 & 1066 & 2376 \\
\hline
\end{tabular}

Os dados da tabela 30 permitem concluir que existe uma associação positiva entre anos de experiência profissional e mobilidade psicológica. Entre as pessoas com alta mobilidade psicológica, 14,4\% tem entre 1 e 2 anos de experiência profissional e 39,4\% tem mais de 5 anos de experiência profissional. Entre as pessoas com baixa mobilidade psicológica, 18,7\% tem entre 1 e 2 anos de experiência profissional e 37,1\% tem mais de 5 anos de experiência profissional.

Tabela 30 - Tabulação cruzada: mobilidade psicológica e anos de experiência profissional

\begin{tabular}{|c|c|c|c|c|}
\hline \multicolumn{2}{|c|}{ Anos de Experiência Profissional } & Alta MP & Baixa MP & Total \\
\hline \multirow{2}{*}{ Entre 1 e 2 anos } & Frequência & 188 & 199 & 387 \\
\cline { 2 - 5 } & $\%$ & $14,4 \%$ & $18,7 \%$ & $16,3 \%$ \\
\hline \multirow{2}{*}{ Entre 2 e 3 anos } & Frequência & 237 & 170 & 407 \\
\cline { 2 - 5 } & $\%$ & $18,1 \%$ & $15,9 \%$ & $17,1 \%$ \\
\hline \multirow{2}{*}{ Entre 3 e 5 anos } & Frequência & 368 & 302 & 670 \\
\cline { 2 - 5 } & $\%$ & $28,1 \%$ & $28,3 \%$ & $28,2 \%$ \\
\hline \multirow{2}{*}{ Entre 5 e 7 anos } & Frequência & 278 & 223 & 501 \\
\cline { 2 - 5 } & $\%$ & $21,2 \%$ & $20,9 \%$ & $21,1 \%$ \\
\hline \multirow{2}{*}{ Mais de 7 anos } & Frequência & 239 & 172 & 411 \\
\cline { 2 - 5 } & $\%$ & $18,2 \%$ & $16,1 \%$ & $17,3 \%$ \\
\hline Total & Frequência & 1310 & 1066 & 2376 \\
\hline
\end{tabular}




\begin{tabular}{|c|c|c|c|c|}
\hline \multicolumn{2}{|c|}{ Anos de Experiência Profissional } & Alta MP & Baixa MP & Total \\
\hline & $\%$ & $100,0 \%$ & $100,0 \%$ & $100,0 \%$ \\
\hline
\end{tabular}

Existe uma associação positiva entre mobilidade psicológica e nível do cargo. A proporção de indivíduos em cargos de liderança é maior entre aqueles com alta mobilidade psicológica $(16,4 \%)$ do que entre aqueles com baixa mobilidade psicológica $(13,1 \%)$ e a proporção de estagiários é menor.

Tabela 31 - Tabulação cruzada: mobilidade psicológica e cargo

\begin{tabular}{|c|c|c|c|c|}
\hline \multicolumn{2}{|c|}{ Cargo } & Alta MP & Baixa MP & Total \\
\hline \multirow{2}{*}{ Diretor / Gerente } & Frequência & 41 & 31 & 72 \\
\cline { 2 - 5 } & $\%$ & $3,1 \%$ & $2,9 \%$ & $3,0 \%$ \\
\hline \multirow{2}{*}{$\begin{array}{c}\text { Coordenador / Supervisor / } \\
\text { Consultor }\end{array}$} & Frequência & 174 & 110 & 284 \\
\cline { 2 - 5 } Analista / Auxiliar / Assistente & $\%$ & $13,3 \%$ & $10,3 \%$ & $12,0 \%$ \\
\cline { 2 - 5 } & Frequência & 677 & 522 & 1199 \\
\cline { 2 - 5 } & $\%$ & $51,7 \%$ & $49,0 \%$ & $50,5 \%$ \\
\cline { 2 - 5 } Trainee & Frequência & 70 & 56 & 126 \\
\cline { 2 - 5 } & $\%$ & $5,3 \%$ & $5,3 \%$ & $5,3 \%$ \\
\cline { 2 - 5 } Estagiário & Frequência & 216 & 207 & 423 \\
\hline \multirow{2}{*}{ Outro } & Frequência & $16,5 \%$ & $19,4 \%$ & $17,8 \%$ \\
\cline { 2 - 5 } & $\%$ & $10,1 \%$ & 140 & 272 \\
\hline \multirow{2}{*}{ Total } & Frequência & 1310 & $13,1 \%$ & $11,4 \%$ \\
\cline { 2 - 5 } & $\%$ & $100,0 \%$ & $100,0 \%$ & $100,0 \%$ \\
\hline
\end{tabular}

Conclui-se que a alta mobilidade psicológica é mais frequente em indivíduos de maior escolaridade, maior renda individual e familiar, de cargos mais altos e maior tempo de experiência profissional.

A maior escolaridade, aliadas ao alto poder aquisitivo e ao conhecimento do mercado de trabalho, adquirido pela experiência profissional, possibilitam ao ator de carreira maior liberdade para buscar o desenvolvimento e explorar relações fora do ambiente de trabalho e dos limites da organização, explicando a maior mobilidade psicológica.

Segers et al (2008) também encontraram uma relação positiva entre mobilidade psicológica e escolaridade. Além disso, eles também encontraram uma relação positiva entre mobilidade psicológica e tempo de experiência em posição de gestão, semelhante aos achados de Briscoe et al (2006) e de Silva (2009) que observaram essa relação entre mobilidade psicológica e 
tempo de experiência profissional. Esses resultados são semelhantes aos encontrados na presente pesquisa.

Segers et al (2008) e Silva (2009) identificaram que os mais jovens apresentam maior mobilidade psicológica. Como a presente amostra contou apenas com indivíduos jovens, não foi possível comparar esses achados.

Outro resultado obtido por Segers et al (2008) foi que a mobilidade psicológica é mais presente entre as mulheres e Silva (2009) identificou que existe uma fraca relação inversa entre mobilidade psicológica e o fato de estar empregado. Esses achados não foram confirmados na amostra analisada.

\section{Mobilidade Física}

Analisando a associação entre ano de nascimento e mobilidade física, é possível concluir pela tabela 32 que existe menor proporção de indivíduos nascidos entre 1982 e 1985 com alta mobilidade física $(28,8 \%)$ do que indivíduos nascidos entre esses anos com baixa mobilidade física (30,4\%). Observa-se também menor proporção de indivíduos nascidos entre 1990 e 1994 com alta mobilidade física $(16,1 \%)$ do que indivíduos nascidos entre esses anos com baixa mobilidade física $(16,6 \%)$. Os indivíduos de alta mobilidade física estão mais concentrados nas datas de nascimento entre 1986 e 1989, ou seja, têm idade média entre 23 e 26 anos.

Tanto Segers et al (2008) quanto Silva (2009) observaram uma relação inversa entre a idade e a mobilidade física. O presente estudo trouxe resultados semelhantes, já que os indivíduos com mais de 26 anos apresentam menor mobilidade física.

Tabela 32 - Tabulação cruzada: mobilidade física e ano de nascimento

\begin{tabular}{|c|c|c|c|c|}
\hline \multicolumn{2}{|c|}{ Ano de Nascimento } & Alta MF & Baixa MF & Total \\
\hline 1982-1985 & Frequência & 382 & 320 & 702 \\
\hline & $\%$ & $28,8 \%$ & $30,4 \%$ & $29,5 \%$ \\
\hline 1986-1989 & Frequência & 730 & 557 & 1287 \\
\hline & $\%$ & $55,1 \%$ & $53,0 \%$ & $54,2 \%$ \\
\hline 1990-1994 & Frequência & 213 & 174 & 387 \\
\hline & $\%$ & $16,1 \%$ & $16,6 \%$ & $16,3 \%$ \\
\hline
\end{tabular}




\begin{tabular}{|l|c|c|c|c|}
\hline \multicolumn{2}{|l|}{ Ano de Nascimento } & Alta MF & Baixa MF & Total \\
\hline Total & Frequência & 1325 & 1051 & 2376 \\
\hline & $\%$ & $100,0 \%$ & $100,0 \%$ & $100,0 \%$ \\
\hline
\end{tabular}

Analisando a associação entre mobilidade física e gênero através da tabela 33, observa-se que existem mais mulheres com alta mobilidade física do que os homens. Segers et al (2008) encontraram maior mobilidade física entre os homens, mas isso é atribuído pelos autores as descontinuidades na carreira relativa ao nascimento de filhos e as expectativas sociais em relação ao homem no sustento da casa. O resultado oposto ao de Segers et al (2008) encontrado no presente estudo pode estar relacionado ao fato de a amostra analisada ser formada por jovens na maioria solteiros, que não estão assumindo essas responsabilidades nesse momento.

Tabela 33 - Tabulação cruzada: mobilidade física e gênero

\begin{tabular}{|c|c|c|c|c|}
\hline \multicolumn{2}{|c|}{ Gênero } & Alta MF & Baixa MF & Total \\
\hline Feminino & Frequência & 777 & 578 & 1355 \\
\hline & $\%$ & $\mathbf{5 8 , 6 \%}$ & $\mathbf{5 5 , 0 \%}$ & $57,0 \%$ \\
\hline Masculino & Frequência & 548 & 473 & 1021 \\
\hline & $\%$ & $\mathbf{4 1 , 4 \%}$ & $\mathbf{4 5 , 0 \%}$ & $43,0 \%$ \\
\hline Total & Frequência & 1325 & 1051 & 2376 \\
\hline & $\%$ & $100,0 \%$ & $100,0 \%$ & $100,0 \%$ \\
\hline
\end{tabular}

Existe menor proporção de pessoas com baixa escolaridade entre aqueles que têm alta mobilidade física $(5,4 \%)$ do que entre aqueles que têm baixa mobilidade física $(11,2 \%)$. Essa associação positiva entre escolaridade e mobilidade física encontrada no presente estudo é semelhante à encontrada por Segers et al (2008).

Tabela 34 - Tabulação cruzada: mobilidade física e escolaridade

\begin{tabular}{|c|c|c|c|c|}
\hline \multicolumn{2}{|c|}{ Escolaridade } & Alta MF & Baixa MF & Total \\
\hline \multirow{2}{*}{$\begin{array}{c}\text { Ensino Fundamental } / \\
\text { Médio }\end{array}$} & Frequência & 72 & 118 & 190 \\
\cline { 2 - 5 } & $\%$ & $5,4 \%$ & $11,2 \%$ & $8,0 \%$ \\
\hline \multirow{2}{*}{ Ensino Superior } & Frequência & 950 & 733 & 1683 \\
\cline { 2 - 5 } & $\%$ & $71,7 \%$ & $69,7 \%$ & $70,8 \%$ \\
\hline \multirow{2}{*}{ Pós-Graduação } & Frequência & 303 & 200 & 503 \\
\cline { 2 - 5 } & $\%$ & $22,9 \%$ & $19,0 \%$ & $21,2 \%$ \\
\hline \multirow{2}{*}{ Total } & Frequência & 1325 & 1051 & 2376 \\
\cline { 2 - 5 } & $\%$ & $100,0 \%$ & $100,0 \%$ & $100,0 \%$ \\
\hline
\end{tabular}


É possível notar na tabela 35 que indivíduos com alta mobilidade física têm maior nível de renda individual do que os indivíduos com baixa mobilidade física. 62,9\% dos indivíduos com alta mobilidade física tem renda superior a 4 salários mínimos, proporção maior do que os $52 \%$ das pessoas que tem baixa mobilidade psicológica e estão nessa faixa de renda. A tabela 36 mostra que a mesma associação acontece com a renda familiar. Enquanto 38,9\% dos indivíduos com alta mobilidade física tem renda familiar superior a 10 salários, apenas 30,2\% dos indivíduos com baixa mobilidade física tem essa faixa de renda.

Tabela 35 - Tabulação cruzada: mobilidade física e renda individual

\begin{tabular}{|c|c|c|c|c|}
\hline \multicolumn{2}{|c|}{ Renda Média Individual } & Alta MF & Baixa MF & Total \\
\hline \multirow{2}{*}{ Sem rendimento } & Frequência & 59 & 71 & 130 \\
\hline & $\%$ & $4,5 \%$ & $6,8 \%$ & $5,5 \%$ \\
\hline \multirow{2}{*}{ Até $\mathbf{R} \$ \mathbf{6 2 2 , 0 0}$} & Frequência & 86 & 88 & 174 \\
\hline & $\%$ & $6,5 \%$ & $8,4 \%$ & $7,3 \%$ \\
\hline \multirow{2}{*}{ entre $R \$ 622,00$ e $R \$ 1.244,00$} & Frequência & 347 & 346 & 693 \\
\hline & $\%$ & $26,2 \%$ & $32,9 \%$ & $29,2 \%$ \\
\hline \multirow{2}{*}{$\begin{array}{c}\text { entre } R \$ 1.244,00 \text { e } R \$ \\
1.866,00\end{array}$} & Frequência & 285 & 187 & 472 \\
\hline & $\%$ & $21,5 \%$ & $17,8 \%$ & $19,9 \%$ \\
\hline \multirow{2}{*}{$\begin{array}{c}\text { entre } R \$ 1.866,00 \text { e } R \$ \\
3.110,00\end{array}$} & Frequência & 273 & 194 & 467 \\
\hline & $\%$ & $20,6 \%$ & $18,5 \%$ & $19,7 \%$ \\
\hline \multirow{2}{*}{$\begin{array}{c}\text { entre } R \$ 3.110,00 \text { e } R \$ \\
6.220,00\end{array}$} & Frequência & 238 & 141 & 379 \\
\hline & $\%$ & $18,0 \%$ & $13,4 \%$ & $16,0 \%$ \\
\hline \multirow{2}{*}{ Mais de $R \$ 6.220,00$} & Frequência & 37 & 24 & 61 \\
\hline & $\%$ & $2,8 \%$ & $2,3 \%$ & $2,6 \%$ \\
\hline \multirow{2}{*}{ Total } & Frequência & 1325 & 1051 & 2376 \\
\hline & $\%$ & $100,0 \%$ & $100,0 \%$ & $100,0 \%$ \\
\hline
\end{tabular}

Tabela 36 - Tabulação cruzada: mobilidade física e renda familiar

\begin{tabular}{|c|c|c|c|c|}
\hline \multicolumn{2}{|c|}{ Renda Média Familiar } & Alta MF & Baixa MF & Total \\
\hline \multirow{2}{*}{ Até R\$ 1.244,00 } & Frequência & 74 & 103 & 177 \\
\cline { 2 - 5 } & $\%$ & $\mathbf{5 , 6 \%}$ & $\mathbf{9 , 8 \%}$ & $7,4 \%$ \\
\hline entre R\$ 1.244,00 e R\$ & Frequência & 221 & 196 & 417 \\
\cline { 2 - 5 } $\mathbf{2 . 4 8 8 , 0 0}$ & $\%$ & $\mathbf{1 6 , 7 \%}$ & $\mathbf{1 8 , 6 \%}$ & $17,6 \%$ \\
\hline entre R\$ 2.448,00 e R\$ & Frequência & 514 & 435 & 949 \\
\cline { 2 - 5 } entre R\$ 6.220,00 e R\$ & $\%$ & $38,8 \%$ & $41,4 \%$ & $39,9 \%$ \\
\hline $\mathbf{1 2 . 4 4 0 , 0 0}$ & Frequência & 326 & 200 & 526 \\
\cline { 2 - 5 } Mais de R\$ 12.440 & $\%$ & $\mathbf{2 4 , 6 \%}$ & $\mathbf{1 9 , 0 \%}$ & $22,1 \%$ \\
\hline \multirow{2}{*}{ Total } & Frequência & 190 & 117 & 307 \\
\cline { 2 - 5 } & $\%$ & $\mathbf{1 4 , 3 \%}$ & $\mathbf{1 1 , 1 \%}$ & $12,9 \%$ \\
\hline & Frequência & 1325 & 1051 & 2376 \\
\cline { 2 - 5 } & $\%$ & $100,0 \%$ & $100,0 \%$ & $100,0 \%$ \\
\hline
\end{tabular}

Como era esperado, as pessoas com alta mobilidade física apresentou um maior número de empregadores nos últimos 5 anos do que as pessoas com baixa mobilidade física, conforme 
demonstra a tabela 37. Esse resultado afirma a consistência entre as respostas dadas a essas questões e o efetivo comportamento de movimentação dos respondentes.

Tabela 37 - Tabulação cruzada: mobilidade física e número de empregadores

\begin{tabular}{|c|c|c|c|c|}
\hline \multicolumn{2}{|c|}{$\mathrm{N}^{\circ}$ de Empregadores nos últimos 5 anos } & Alta MF & Baixa MF & Total \\
\hline \multirow{2}{*}{ O a 1} & Frequência & 153 & 158 & 311 \\
\hline & $\%$ & $11,5 \%$ & $15,0 \%$ & $13,1 \%$ \\
\hline \multirow{2}{*}{2} & Frequência & 341 & 292 & 633 \\
\hline & $\%$ & $25,7 \%$ & $27,8 \%$ & $26,6 \%$ \\
\hline \multirow{2}{*}{3} & Frequência & 431 & 320 & 751 \\
\hline & $\%$ & $32,5 \%$ & $30,4 \%$ & $31,6 \%$ \\
\hline \multirow{2}{*}{4} & Frequência & 212 & 149 & 361 \\
\hline & $\%$ & $16,0 \%$ & $14,2 \%$ & $15,2 \%$ \\
\hline \multirow{2}{*}{5} & Frequência & 100 & 82 & 182 \\
\hline & $\%$ & $7,5 \%$ & $7,8 \%$ & $7,7 \%$ \\
\hline \multirow{2}{*}{6 ou mais } & Frequência & 88 & 50 & 138 \\
\hline & $\%$ & $6,6 \%$ & $4,8 \%$ & $5,8 \%$ \\
\hline \multirow{2}{*}{ Total } & Frequência & 1325 & 1051 & 2376 \\
\hline & $\%$ & $100,0 \%$ & $100,0 \%$ & $100,0 \%$ \\
\hline
\end{tabular}

Conclui-se que a alta mobilidade física é mais frequente em indivíduos com idade entre 23 e 26 anos, para as mulheres, para pessoas de maior escolaridade, maior renda individual e familiar e entre os indivíduos que já tem um histórico de alta movimentação entre empregadores.

Nota-se que algumas variáveis demográficas não têm associação significante com nenhuma atitude de carreira, tais como, ter filhos, o tempo de uso da internet e se o respondente trabalha atualmente.

\subsubsection{Análise da influência das características demográficas e profissionais nos perfis de carreira}

A partir da definição dos oito grupos ou perfis de carreira, foram averiguados se os indivíduos que fazem parte desses grupos se distinguiam significativamente quanto às características demográficas investigadas em relação aos demais grupos. Para isso, foram realizados os testes qui-quadrado entre os 8 perfis e as características demográficas. Os resultados dos valores-p 
estão descritos na tabela 38 e os valores-p significantes, ou seja, iguais ou inferiores a 5\%, estão sinalizados em laranja.

Tabela 38 - Resultados dos valores-p gerados pelo teste Qui-Quadrado analisando a associação entre os 8 perfis de carreira encontrados e variáveis demográficas

\begin{tabular}{|c|c|c|c|c|c|c|c|c|}
\hline & $\begin{array}{c}\text { Perdi- } \\
\text { do }\end{array}$ & $\begin{array}{c}\text { Prote- } \\
\text { ano } \\
\text { Estável }\end{array}$ & $\begin{array}{c}\text { Viajan- } \\
\text { te } \\
\text { Orien- } \\
\text { tado }\end{array}$ & $\begin{array}{c}\text { Bus- } \\
\text { cador }\end{array}$ & $\begin{array}{c}\text { Organiza- } \\
\text { cional }\end{array}$ & $\begin{array}{c}\text { Cidadão } \\
\text { Sólido }\end{array}$ & $\begin{array}{c}\text { Contra- } \\
\text { tado } \\
\text { da } \\
\text { Carreira } \\
\text { Proteana }\end{array}$ \\
\hline $\begin{array}{c}\text { Ano de } \\
\text { Nascimento }\end{array}$ & $34 \%$ & $3 \%$ & $24 \%$ & $6 \%$ & $49 \%$ & $32 \%$ & $10 \%$ & $1 \%$ \\
\hline Gênero & $97 \%$ & $56 \%$ & $91 \%$ & $1 \%$ & $77 \%$ & $1 \%$ & $45 \%$ & $14 \%$ \\
\hline Escolaridade & $0 \%$ & $59 \%$ & $6 \%$ & $6 \%$ & $0 \%$ & $66 \%$ & $94 \%$ & $0 \%$ \\
\hline Estado Civil & $63 \%$ & $89 \%$ & $52 \%$ & $15 \%$ & $42 \%$ & $99 \%$ & $62 \%$ & $5 \%$ \\
\hline Filhos & $74 \%$ & $32 \%$ & $23 \%$ & $26 \%$ & $43 \%$ & $16 \%$ & $66 \%$ & $56 \%$ \\
\hline $\begin{array}{c}\text { Renda } \\
\text { Individual }\end{array}$ & $6 \%$ & $30 \%$ & $57 \%$ & $5 \%$ & $2 \%$ & $10 \%$ & $96 \%$ & $0 \%$ \\
\hline $\begin{array}{c}\text { Renda } \\
\text { Familiar }\end{array}$ & $17 \%$ & $63 \%$ & $23 \%$ & $29 \%$ & $36 \%$ & $0 \%$ & $59 \%$ & $0 \%$ \\
\hline Estado/Cidade & $49 \%$ & $2 \%$ & $70 \%$ & $94 \%$ & $18 \%$ & $7 \%$ & $38 \%$ & $14 \%$ \\
\hline $\begin{array}{c}\text { Tempo de uso } \\
\text { da Internet }\end{array}$ & $81 \%$ & $32 \%$ & $73 \%$ & $62 \%$ & $17 \%$ & $21 \%$ & $27 \%$ & $16 \%$ \\
\hline $\begin{array}{c}\text { Trabalha } \\
\text { atualmente }\end{array}$ & $18 \%$ & $9 \%$ & $71 \%$ & $30 \%$ & $1 \%$ & $4 \%$ & $39 \%$ & $1 \%$ \\
\hline $\begin{array}{c}\text { Anos de } \\
\text { Experiência } \\
\text { Profissional }\end{array}$ & $16 \%$ & $32 \%$ & $6 \%$ & $43 \%$ & $86 \%$ & $32 \%$ & $5 \%$ & $7 \%$ \\
\hline $\begin{array}{c}\text { Cargo } \\
\text { Número de }\end{array}$ & $35 \%$ & $23 \%$ & $25 \%$ & $4 \%$ & $22 \%$ & $70 \%$ & $50 \%$ & $3 \%$ \\
\hline
\end{tabular}

Serão analisadas as diferenças de frequência das variáveis significantes em cada grupo.

\section{Grupo 1 - "Perdido"}

A única variável demográfica que tem significância para definir o grupo "Perdido" é a escolaridade. Observa-se pela tabela 39 que os indivíduos desse grupo têm menor escolaridade do que os demais respondentes, sendo que 19,3\% cursaram até o ensino fundamental ou médio, valor acima dos 7,6\% que tem esse grau de instrução no restante da amostra. A baixa escolaridade coloca esses indivíduos em uma posição de menor número de opções de trabalho e isso pode estimulá-los a manter o espírito de sobrevivência descrito por Briscoe e Hall (2006) para esse perfil. A visão de poucas oportunidades pode gerar a baixa autonomia, orientação pelos valores e mobilidade. Esse resultado da associação do perfil 
"Perdido" com a baixa escolaridade também foi encontrado por Segers et al (2008) e foi descrito por Sullivan e Arthur (2006).

Tabela 39 - Tabulação cruzada: "Perdido" e escolaridade

\begin{tabular}{|c|c|c|c|c|}
\hline \multicolumn{2}{|c|}{ Escolaridade } & Perdido & $\begin{array}{c}\text { Demais } \\
\text { respondentes }\end{array}$ & Total \\
\hline \multirow{2}{*}{$\begin{array}{c}\text { Ensino Fundamental / } \\
\text { Médio }\end{array}$} & Frequência & 17 & 173 & 190 \\
\cline { 2 - 5 } & $\%$ & $\mathbf{1 9 , 3 \%}$ & $\mathbf{7 , 6 \%}$ & $8,0 \%$ \\
\hline \multirow{2}{*}{ Ensino Superior } & Frequência & 55 & 1628 & 1683 \\
\cline { 2 - 5 } & $\%$ & $\mathbf{6 2 , 5 \%}$ & $\mathbf{7 1 , 2 \%}$ & $70,8 \%$ \\
\hline \multirow{2}{*}{ Pós-Graduação } & Frequência & 16 & 487 & 503 \\
\cline { 2 - 5 } & $\%$ & $\mathbf{1 8 , 2 \%}$ & $\mathbf{2 1 , 3 \%}$ & $21,2 \%$ \\
\hline \multirow{2}{*}{ Total } & Frequência & 88 & 2288 & 2376 \\
\cline { 2 - 5 } & $\%$ & $100,0 \%$ & $100,0 \%$ & $100,0 \%$ \\
\hline
\end{tabular}

\section{Grupo 2 - Proteano Estável}

A tabela 40 indica que o grupo "Proteano Estável" apresenta maior proporção de indivíduos mais jovens do que o restante da amostra. 20,5\% dos indivíduos do Grupo 2 nasceram entre 1990 e 1994, logo tem idade aproximada de 18 a 22 anos, os demais respondentes apresentam uma proporção menor de indivíduos nessa faixa etária (15,7\%). Além disso, 47,3\% dos indivíduos do grupo "Proteano Estável" nasceram entre 1986 e 1989, tendo idade aproximada de 23 a 26 anos, enquanto dentre os demais respondentes existe uma proporção maior de indivíduos nessas idades, contando com $55,1 \%$ do total do restante da amostra.

Tabela 40 - Tabulação cruzada: "Proteano Estável” e ano de Nascimento

\begin{tabular}{|c|c|c|c|c|}
\hline \multicolumn{2}{|c|}{ Ano de Nascimento } & $\begin{array}{c}\text { Proteano } \\
\text { Estável }\end{array}$ & $\begin{array}{c}\text { Demais } \\
\text { respondentes }\end{array}$ & Total \\
\hline $\mathbf{1 9 8 2 - 1 9 8 5}$ & Frequência & 91 & 611 & 702 \\
\hline & $\%$ & $32,2 \%$ & $29,2 \%$ & $29,5 \%$ \\
\hline $\mathbf{1 9 8 6 - 1 9 8 9}$ & Frequência & 134 & 1153 & 1287 \\
\hline & $\%$ & $\mathbf{4 7 , 3 \%}$ & $\mathbf{5 5 , 1 \%}$ & $\mathbf{5 4 , 2 \%}$ \\
\hline $\mathbf{1 9 9 0 - 1 9 9 4}$ & Frequência & 58 & 329 & 387 \\
\hline & $\%$ & $\mathbf{2 0 , 5 \%}$ & $\mathbf{1 5 , 7 \%}$ & $\mathbf{1 6 , 3 \%}$ \\
\hline Total & Frequência & 283 & 2093 & 2376 \\
\hline & $\%$ & $100,0 \%$ & $100,0 \%$ & $100,0 \%$ \\
\hline
\end{tabular}

O "Proteano Estável" tem maior predominância de indivíduos de São Paulo - Capital (30\%) e do Sul do país (15,9\%) quando comparado ao restante da amostra (25,4\% e 11\%, respectivamente) e menor presença de pessoas do Norte, Nordeste e Centro-oeste $(11,7 \%)$ e 
do interior de São Paulo (20,8\%) do que o restante da amostra (16,5\% e 25,1\%, respectivamente). Esse é o único grupo que indicou uma diferença estatisticamente significante em relação ao estado/cidade de residência sugerindo a influência da cultura no perfil de carreira descrita por Briscoe et al (2012) e atestando que a cidade de São Paulo é favorável ao desenvolvimento da carreira proteana (RIBEIRO et al, 2009).

Tabela 41 - Tabulação cruzada: "Proteano Estável" e estado/cidade de residência

\begin{tabular}{|c|c|c|c|c|}
\hline \multicolumn{2}{|l|}{ Estado/Cidade } & Proteano Estável & $\begin{array}{c}\text { Demais } \\
\text { respondentes }\end{array}$ & Total \\
\hline \multirow{2}{*}{$\begin{array}{c}\text { Norte / Nordeste / Centro } \\
\text { Oeste }\end{array}$} & Frequência & 33 & 346 & 379 \\
\hline & $\%$ & $11,7 \%$ & $16,5 \%$ & $16,0 \%$ \\
\hline \multirow{2}{*}{ Sul } & Frequência & 45 & 230 & 275 \\
\hline & $\%$ & $15,9 \%$ & $11,0 \%$ & $11,6 \%$ \\
\hline \multirow{2}{*}{ Minas Gerais e Espírito Santo } & Frequência & 36 & 247 & 283 \\
\hline & $\%$ & $12,7 \%$ & $11,8 \%$ & $11,9 \%$ \\
\hline \multirow{2}{*}{ Rio de Janeiro } & Frequência & 25 & 213 & 238 \\
\hline & $\%$ & $8,8 \%$ & $10,2 \%$ & $10,0 \%$ \\
\hline \multirow{2}{*}{ São Paulo - Capital } & Frequência & 85 & 531 & 616 \\
\hline & $\%$ & 30,0\% & $25,4 \%$ & $25,9 \%$ \\
\hline \multirow{2}{*}{ São Paulo - Interior } & Frequência & 59 & 526 & 585 \\
\hline & $\%$ & $20,8 \%$ & $25,1 \%$ & $24,6 \%$ \\
\hline \multirow{2}{*}{ Total } & Frequência & 283 & 2093 & 2376 \\
\hline & $\%$ & $100,0 \%$ & $100,0 \%$ & $100,0 \%$ \\
\hline
\end{tabular}

Conclui-se que os "Proteanos Estáveis" tem maior presença de indivíduos entre 18 e 22 anos e entre 27 e 30 anos de idade e de residentes da cidade de São Paulo e do sul do país do que o restante da amostra.

\section{Grupo 3 - Viajante Orientado}

Nenhuma variável demográfica estudada apresentou diferença estatisticamente significante nos testes qui-quadrado referente à comparação do grupo "viajante orientado" com o restante da amostra. 


\section{Grupo 4 - Buscador}

O gênero apresentou diferença nesse grupo, sendo que existe uma proporção maior de mulheres $(64,2 \%)$ nesse grupo do que entre os demais respondentes $(56 \%)$. A renda individual também apresentou diferença significante. Observa-se que existe uma proporção maior de indivíduos sem renda no grupo "Buscador" $(7,3 \%)$ e uma menor proporção de indivíduos com ganho de até 2 salários mínimos. Existe também uma maior proporção de pessoas que tem renda entre 2 e 5 salários mínimos $(45,7 \%)$ do que entre os demais respondentes $(38,6 \%)$ e uma menor proporção de pessoas que tem renda superior à 10 salários mínimos $(1 \%$ em relação a $2,8 \%$ dos demais respondentes).

Tabela 42 - Tabulação cruzada: "Buscador" e gênero

\begin{tabular}{|c|c|c|c|c|}
\hline \multicolumn{2}{|c|}{ Gênero } & Buscador & $\begin{array}{c}\text { Demais } \\
\text { respondentes }\end{array}$ & Total \\
\hline Feminino & Frequência & 194 & 1161 & 1355 \\
\hline & $\%$ & $\mathbf{6 4 , 2 \%}$ & $\mathbf{5 6 , 0 \%}$ & $57 \%$ \\
\hline Masculino & Frequência & 108 & 913 & 1021 \\
\hline & $\%$ & $35,8 \%$ & $44,0 \%$ & $43 \%$ \\
\hline Total & Frequência & 302 & 2074 & 2376 \\
\hline & $\%$ & $100,0 \%$ & $100,0 \%$ & $100,0 \%$ \\
\hline
\end{tabular}

Tabela 43 - Tabulação cruzada: "Buscador" e renda individual

\begin{tabular}{|c|c|c|c|c|}
\hline \multicolumn{2}{|c|}{ Renda Média Individual } & \multirow{2}{*}{$\begin{array}{c}\text { Buscador } \\
22\end{array}$} & \multirow{2}{*}{$\begin{array}{c}\text { Demais } \\
\text { respondentes }\end{array}$} & \multirow{2}{*}{$\begin{array}{c}\text { Total } \\
130\end{array}$} \\
\hline & Frequência & & & \\
\hline Sem rendimento & $\%$ & $7,3 \%$ & $5,2 \%$ & $5,5 \%$ \\
\hline \multirow{2}{*}{ Até R\$ 622,00 } & Frequência & 17 & 157 & 174 \\
\hline & $\%$ & $5,6 \%$ & $7,6 \%$ & $7,3 \%$ \\
\hline \multirow{2}{*}{ entre $R \$ 622,00$ e $R \$ 1.244,00$} & Frequência & 76 & 617 & 693 \\
\hline & $\%$ & $25,2 \%$ & $29,7 \%$ & $29,2 \%$ \\
\hline \multirow{2}{*}{$\begin{array}{c}\text { entre } R \$ 1.244,00 \text { e } R \$ \\
1.866,00\end{array}$} & Frequência & 73 & 399 & 472 \\
\hline & $\%$ & $24,2 \%$ & $19,2 \%$ & $19,9 \%$ \\
\hline \multirow{2}{*}{$\begin{array}{c}\text { entre } R \$ 1.866,00 \text { e } R \$ \\
3.110,00\end{array}$} & Frequência & 65 & 402 & 467 \\
\hline & $\%$ & $21,5 \%$ & $19,4 \%$ & $19,7 \%$ \\
\hline \multirow{2}{*}{$\begin{array}{c}\text { entre } R \$ 3.110,00 \text { e } R \$ \\
6.220,00\end{array}$} & Frequência & 46 & 333 & 379 \\
\hline & $\%$ & $15,2 \%$ & $16,1 \%$ & $16,0 \%$ \\
\hline \multirow{2}{*}{ Mais de $\mathrm{R} \$ \mathbf{6 . 2 2 0 , 0 0}$} & Frequência & 3 & 58 & 61 \\
\hline & $\%$ & $1,0 \%$ & $2,8 \%$ & $2,6 \%$ \\
\hline \multirow{2}{*}{ Total } & Frequência & 302 & 2074 & 2376 \\
\hline & $\%$ & $100,0 \%$ & $100,0 \%$ & $100,0 \%$ \\
\hline
\end{tabular}


O grupo "Buscador" apresenta menor quantidade de pessoas em cargos de gestão $(10,6 \%)$ do que o restante da amostra $(15,6 \%)$ e maior quantidade de analistas, auxiliares e assistentes $(58,6 \%)$ do que os demais respondentes $(49,6 \%)$, conforme mostra a tabela 44.

Tabela 44 - Tabulação cruzada: "Buscador" e cargo

\begin{tabular}{|c|c|c|c|c|}
\hline \multicolumn{2}{|c|}{ Cargo } & \multirow{2}{*}{ Buscador } & $\begin{array}{c}\text { Demais } \\
\text { respondentes }\end{array}$ & Total \\
\hline \multirow{2}{*}{ Diretor / Gerente } & Frequência & 5 & 67 & 72 \\
\cline { 2 - 5 } & $\%$ & $1,7 \%$ & $3,2 \%$ & $3,0 \%$ \\
\hline \multirow{2}{*}{$\begin{array}{c}\text { Coordenador / Supervisor / } \\
\text { Consultor }\end{array}$} & Frequência & 27 & 257 & 284 \\
\cline { 2 - 5 } Analista / Auxiliar / Assistente & $\%$ & $8,9 \%$ & $12,4 \%$ & $12,0 \%$ \\
\cline { 2 - 5 } & Frequência & 177 & 1022 & 1199 \\
\hline \multirow{2}{*}{ Trainee } & $\%$ & $58,6 \%$ & $49,3 \%$ & $50,5 \%$ \\
\cline { 2 - 5 } & Frequência & 17 & 109 & 126 \\
\hline \multirow{2}{*}{ Estagiário } & Frequência & $4,6 \%$ & $5,3 \%$ & $5,3 \%$ \\
\cline { 2 - 5 } & $\%$ & $15,2 \%$ & 377 & 423 \\
\hline \multirow{2}{*}{ Outro } & Frequência & 30 & $18,2 \%$ & $17,8 \%$ \\
\cline { 2 - 5 } & $\%$ & $9,9 \%$ & $11,7 \%$ & 272 \\
\hline \multirow{2}{*}{ Total } & Frequência & 302 & 2074 & 2376 \\
\cline { 2 - 5 } & $\%$ & $100,0 \%$ & $100,0 \%$ & $100,0 \%$ \\
\hline
\end{tabular}

Conclui-se que o grupo "Buscador" tem maior proporção de mulheres, de indivíduos de renda individual baixa ou média e de pessoas em cargo de analista, auxiliar ou assistente do que o restante da amostra.

\section{Grupo 5 - “Organizacional”}

A primeira característica demográfica apresentada que se diferencia para esse grupo é a escolaridade. Observa-se na tabela 45 que esse grupo tem maior proporção de indivíduos de baixa escolaridade do que os demais, sendo que 13,4\% tem até o ensino fundamental/médio enquanto essa proporção é de $7,4 \%$ entre os demais respondentes. Existe também menor proporção de pessoas pós-graduadas nesse grupo do que nos demais.

Tabela 45 - Tabulação cruzada: "Organizacional" e escolaridade

\begin{tabular}{|c|c|c|c|c|}
\hline \multicolumn{2}{|c|}{ Escolaridade } & “Organizacional” & $\begin{array}{c}\text { Demais } \\
\text { respondentes }\end{array}$ & Total \\
\hline $\begin{array}{c}\text { Ensino Fundamental / } \\
\text { Médio }\end{array}$ & Frequência & 34 & 156 & 190 \\
\cline { 2 - 5 } & $\%$ & $\mathbf{1 3 , 4 \%}$ & $\mathbf{7 , 4 \%}$ & $8,0 \%$ \\
\hline
\end{tabular}




\begin{tabular}{|c|c|c|c|c|}
\hline \multicolumn{2}{|c|}{ Escolaridade } & “Organizacional” & $\begin{array}{c}\text { Demais } \\
\text { respondentes }\end{array}$ & Total \\
\hline \multirow{2}{*}{ Ensino Superior } & Frequência & 180 & 1503 & 1683 \\
\cline { 2 - 5 } & $\%$ & $70,9 \%$ & $70,8 \%$ & $70,8 \%$ \\
\hline \multirow{2}{*}{ Pós-Graduação } & Frequência & 40 & 463 & 503 \\
\cline { 2 - 5 } & $\%$ & $\mathbf{1 5 , 7 \%}$ & $\mathbf{2 1 , 8 \%}$ & $21,2 \%$ \\
\hline \multirow{2}{*}{ Total } & Frequência & 254 & 2122 & 2376 \\
\cline { 2 - 5 } & $\%$ & $100,0 \%$ & $100,0 \%$ & $100,0 \%$ \\
\hline
\end{tabular}

Analisando a diferença da renda individual mensal do grupo "Organizacional" observa-se uma maior proporção de indivíduos com renda de até 2 salários mínimos e menor proporção de indivíduos com renda superior a isso, logo conclui-se que esse é um grupo com menor rendimento do que os demais. O grupo "Organizacional" também tem uma maior proporção de indivíduos que não trabalham $(23,2 \%)$ do que o restante da amostra $(16,7 \%)$. O fato de um grande número de pessoas desse grupo não trabalhar pode explicar a maior proporção de pessoas sem rendimento e de rendimento inferior.

Tabela 46 - Tabulação cruzada: "Organizacional" e renda individual

\begin{tabular}{|c|c|c|c|c|}
\hline \multicolumn{2}{|c|}{ Renda Média Individual } & \multirow{2}{*}{$\begin{array}{c}\text { Organizacional } \\
21 \\
\end{array}$} & \multirow{2}{*}{$\begin{array}{c}\begin{array}{c}\text { Demais } \\
\text { respondentes }\end{array} \\
109\end{array}$} & \multirow{2}{*}{$\begin{array}{c}\text { Total } \\
130\end{array}$} \\
\hline & Frequência & & & \\
\hline Sem rendimento & $\%$ & $\mathbf{8 , 3 \%}$ & $5,1 \%$ & $5,5 \%$ \\
\hline \multirow{2}{*}{ Até R\$ 622,00 } & Frequência & 25 & 149 & 174 \\
\hline & $\%$ & $9,8 \%$ & $7,0 \%$ & $7,3 \%$ \\
\hline \multirow{2}{*}{ entre $R \$ 622,00$ e $R \$ 1.244,00$} & Frequência & 85 & 608 & 693 \\
\hline & $\%$ & $33,5 \%$ & $28,7 \%$ & $29,2 \%$ \\
\hline \multirow{2}{*}{$\begin{array}{c}\text { entre } R \$ 1.244,00 \text { e } R \$ \\
1.866,00\end{array}$} & Frequência & 46 & 426 & 472 \\
\hline & $\%$ & $18,1 \%$ & $20,1 \%$ & $19,9 \%$ \\
\hline \multirow{2}{*}{$\begin{array}{c}\text { entre } R \$ 1.866,00 \text { e } R \$ \\
3.110,00\end{array}$} & Frequência & 35 & 432 & 467 \\
\hline & $\%$ & $13,8 \%$ & $20,4 \%$ & $19,7 \%$ \\
\hline \multirow{2}{*}{$\begin{array}{c}\text { entre } R \$ 3.110,00 \text { e } R \$ \\
6.220,00\end{array}$} & Frequência & 37 & 342 & 379 \\
\hline & $\%$ & $14,6 \%$ & $16,1 \%$ & $16,0 \%$ \\
\hline \multirow{2}{*}{ Mais de $\mathrm{R} \$ 6.220,00$} & Frequência & 5 & 56 & 61 \\
\hline & $\%$ & $2,0 \%$ & $2,6 \%$ & $2,6 \%$ \\
\hline \multirow{2}{*}{ Total } & Frequência & 254 & 2122 & 2376 \\
\hline & $\%$ & $100,0 \%$ & $100,0 \%$ & $100,0 \%$ \\
\hline
\end{tabular}

Tabela 47 - Tabulação cruzada: "Organizacional" e presença de trabalho atual

\begin{tabular}{|c|c|c|c|c|}
\hline \multicolumn{2}{|c|}{ Trabalha atualmente } & Organizacional & $\begin{array}{c}\text { Demais } \\
\text { respondentes }\end{array}$ & Total \\
\hline Não trabalha & Frequência & 59 & 355 & 59 \\
\hline & $\%$ & $\mathbf{2 3 , 2 \%}$ & $\mathbf{1 6 , 7 \%}$ & $23,2 \%$ \\
\hline Trabalha & Frequência & 195 & 1767 & 195 \\
\hline & $\%$ & $\mathbf{7 6 , 8 \%}$ & $\mathbf{8 3 , 3 \%}$ & $76,8 \%$ \\
\hline
\end{tabular}




\begin{tabular}{|c|c|c|c|c|}
\hline \multicolumn{2}{|c|}{ Trabalha atualmente } & Organizacional & $\begin{array}{c}\text { Demais } \\
\text { respondentes }\end{array}$ & Total \\
\hline Total & Frequência & 254 & 2122 & 254 \\
\hline & $\%$ & $100,0 \%$ & $100,0 \%$ & $100,0 \%$ \\
\hline
\end{tabular}

A movimentação entre empregadores nesse grupo é menor do que no restante da amostra. Observa-se na tabela 48 que $46,1 \%$ das pessoas nesse perfil tiveram entre 0 e 2 empregadores nos últimos 5 anos, enquanto esse percentual foi de $39 \%$ entre os demais respondentes. No restante da amostra, $6,3 \%$ dos indivíduos se movimentaram entre 6 ou mais empregadores nos últimos 5 anos, quanto apenas 1,6\% do grupo "Organizacional" teve esse nível de movimentação.

Tabela 48 - Tabulação cruzada: "Organizacional" e número de empregadores

\begin{tabular}{|c|c|c|c|c|}
\hline \multicolumn{2}{|c|}{$\mathbf{N}^{\mathbf{0}}$ de Empregadores nos últimos 5 anos } & Organizacional & $\begin{array}{c}\text { Demais } \\
\text { respondentes }\end{array}$ & Total \\
\hline \multirow{2}{*}{$\mathbf{0}$ a 1 } & Frequência & 38 & 273 & 311 \\
\cline { 2 - 5 } & $\%$ & $\mathbf{1 5 , 0 \%}$ & $\mathbf{1 2 , 9 \%}$ & $13,1 \%$ \\
\hline \multirow{2}{*}{2} & Frequência & 79 & 554 & 633 \\
\cline { 2 - 5 } & $\%$ & $\mathbf{3 1 , 1 \%}$ & $\mathbf{2 6 , 1 \%}$ & $26,6 \%$ \\
\hline \multirow{2}{*}{3} & Frequência & 82 & 669 & 751 \\
\cline { 2 - 5 } & $\%$ & $32,3 \%$ & $31,5 \%$ & $31,6 \%$ \\
\hline \multirow{2}{*}{$\mathbf{5}$} & Frequência & 32 & 329 & 361 \\
\cline { 2 - 5 } & $\%$ & $12,6 \%$ & $15,5 \%$ & $15,2 \%$ \\
\hline \multirow{2}{*}{$\mathbf{6}$ ou mais } & Frequência & 19 & 163 & 182 \\
\cline { 2 - 5 } & $\%$ & $7,5 \%$ & $7,7 \%$ & $7,7 \%$ \\
\hline \multirow{2}{*}{ Total } & Frequência & 4 & 134 & 138 \\
\cline { 2 - 5 } & $\%$ & $\mathbf{1 , 6 \%}$ & $\mathbf{6 , 3 \%}$ & $5,8 \%$ \\
\hline \multirow{2}{*}{} & Frequência & 254 & 2122 & 2376 \\
\cline { 2 - 5 } & $\%$ & $100,0 \%$ & $100,0 \%$ & $100,0 \%$ \\
\hline
\end{tabular}

Conclui-se que o grupo "Organizacional" tem maior proporção, quando comparado ao restante da amostra, de indivíduos de baixa escolaridade, de baixa renda individual, que não estão trabalhando atualmente e que apresentam pouca movimentação entre empregadores. Esse perfil demográfico é alinhado às características do ator de carreira desse grupo, que apresenta facilidade em trabalhar além das fronteiras psicológicas, mas não das fronteiras físicas, gerando pouca movimentação e maior dificuldade na recolocação. Briscoe e Hall (2006) alertam sobre o risco desse indivíduo não alcançar seu máximo potencial advindo do alinhamento do trabalho executado com seus valores pessoais. 


\section{Grupo 6 - "Cidadão Sólido"}

O grupo "Cidadão Sólido" apresenta maior proporção de indivíduos com renda familiar de até 2 salários $(10,5 \%)$ do que os demais respondentes $(7 \%)$ e maior proporção de indivíduos com renda entre 4 e 10 salários $(45,8 \%)$ do que o restante da amostra (39,2\%). Existe uma menor proporção de indivíduos com renda entre 10 e 20 salários nesse grupo $(14,5 \%)$ do que entre os demais respondentes $(23,1 \%)$. Apesar das variações nas faixas, observa-se que esse é um grupo que apresenta maior proporção de indivíduos de baixa renda familiar do que os demais. Ao agrupar as faixas de renda, é possível notar que 72,7\% do grupo "Cidadão Sólido" é composto por indivíduos com renda média familiar inferior a 10 salários enquanto essa proporção é de $63,9 \%$ entre os demais respondentes.

Tabela 49 - Tabulação cruzada: "Cidadão Sólido" e renda familiar

\begin{tabular}{|c|c|c|c|c|}
\hline \multicolumn{2}{|c|}{ Renda Média Familiar } & \multirow{2}{*}{$\begin{array}{c}\text { Cidadão Sólido } \\
29\end{array}$} & \multirow{2}{*}{$\begin{array}{c}\begin{array}{c}\text { Demais } \\
\text { respondentes }\end{array} \\
148 \\
\end{array}$} & \multirow{2}{*}{$\begin{array}{c}\text { Total } \\
177\end{array}$} \\
\hline Át D\$ 124400 & Frequência & & & \\
\hline Ate R\$ $1.244,00$ & $\%$ & $10,5 \%$ & $7,0 \%$ & $7,4 \%$ \\
\hline \multirow{2}{*}{$\begin{array}{c}\text { entre } R \$ 1.244,00 \text { e } R \$ \\
2.488,00\end{array}$} & Frequência & 45 & 372 & 417 \\
\hline & $\%$ & $16,4 \%$ & $17,7 \%$ & $17,6 \%$ \\
\hline \multirow{2}{*}{$\begin{array}{c}\text { entre } R \$ 2.448,00 \text { e } R \$ \\
6.220,00 \\
\end{array}$} & Frequência & 126 & 823 & 949 \\
\hline & $\%$ & $45,8 \%$ & $39,2 \%$ & $39,9 \%$ \\
\hline \multirow{2}{*}{$\begin{array}{c}\text { entre } R \$ 6.220,00 \text { e } R \$ \\
12.440,00 \\
\end{array}$} & Frequência & 40 & 486 & 526 \\
\hline & $\%$ & $14,5 \%$ & $23,1 \%$ & $22,1 \%$ \\
\hline \multirow{2}{*}{ Mais de $R$ \$ 12.440} & Frequência & 35 & 272 & 307 \\
\hline & $\%$ & $12,7 \%$ & $12,9 \%$ & $12,9 \%$ \\
\hline \multirow{2}{*}{ Total } & Frequência & 275 & 2101 & 2376 \\
\hline & $\%$ & $100,0 \%$ & $100,0 \%$ & $100,0 \%$ \\
\hline
\end{tabular}

Observa-se que entre os Cidadãos Sólidos, existe maior proporção de indivíduos que não trabalham $(21,8 \%)$ do que o restante da amostra $(16,8 \%)$ e maior proporção de homens $(49,8 \%)$ do que os demais respondentes $(42,1 \%)$.

Tabela 50 - Tabulação cruzada: “Cidadão Sólido” e presença de trabalho atual

\begin{tabular}{|c|c|c|c|c|}
\hline \multicolumn{2}{|c|}{ Trabalha atualmente } & Cidadão Sólido & $\begin{array}{c}\text { Demais } \\
\text { respondentes }\end{array}$ & Total \\
\hline Não trabalha & Frequência & 60 & 354 & 414 \\
\hline & $\%$ & $\mathbf{2 1 , 8 \%}$ & $\mathbf{1 6 , 8 \%}$ & $17,4 \%$ \\
\hline Trabalha & Frequência & 215 & 1747 & 1962 \\
\hline & $\%$ & $\mathbf{7 8 , 2 \%}$ & $\mathbf{8 3 , 2 \%}$ & $82,6 \%$ \\
\hline Total & Frequência & 275 & 2101 & 2376 \\
\hline & $\%$ & $100,0 \%$ & $100,0 \%$ & $100,0 \%$ \\
\hline
\end{tabular}


Tabela 51 - Tabulação cruzada: "Cidadão Sólido" e gênero

\begin{tabular}{|c|c|c|c|c|}
\hline \multicolumn{2}{|c|}{ Gênero } & Cidadão Sólido & $\begin{array}{c}\text { Demais } \\
\text { respondentes }\end{array}$ & Total \\
\hline Feminino & Frequência & 138 & 1217 & 1355 \\
\hline & $\%$ & $\mathbf{5 0 , 2 \%}$ & $\mathbf{5 7 , 9 \%}$ & $57,0 \%$ \\
\hline Masculino & Frequência & 137 & 884 & 1021 \\
\hline & $\%$ & $\mathbf{4 9 , 8 \%}$ & $\mathbf{4 2 , 1 \%}$ & $43,0 \%$ \\
\hline Total & Frequência & 275 & 2101 & 2376 \\
\hline & $\%$ & $100,0 \%$ & $100,0 \%$ & $100,0 \%$ \\
\hline
\end{tabular}

Conclui-se que o grupo "Cidadão Sólido" tem maior proporção, em relação ao restante da amostra, de homens, com renda individual de até dois salários mínimos e que não trabalham.

\section{Grupo 7 - “Contratado"}

Esse grupo apenas se diferencia significativamente dos demais em relação ao tempo de experiência profissional. Ele apresenta maior proporção de indivíduos com experiência profissional de 1 a 2 anos (18,2\%) do que o restante da amostra (16\%) e maior proporção de pessoas com experiência superior a 5 anos $(42,3 \%)$ do que os demais respondentes $(37,8 \%)$. Esse resultado é semelhante ao encontrado por Segers et al (2008) para esse grupo.

Tabela 52 - Tabulação cruzada: "Contratado" e anos de experiência profissional

\begin{tabular}{|c|c|c|c|c|}
\hline \multicolumn{2}{|l|}{ Anos de Experiência Profissional } & Contratado & $\begin{array}{c}\text { Demais } \\
\text { respondentes }\end{array}$ & Total \\
\hline \multirow{2}{*}{ Entre 1 e 2 anos } & Frequência & 59 & 328 & 387 \\
\cline { 2 - 5 } & $\%$ & $\mathbf{1 8 , 2 \%}$ & $\mathbf{1 6 , 0 \%}$ & $16,3 \%$ \\
\hline \multirow{2}{*}{ Entre 2 e 3 anos } & Frequência & 37 & 370 & 407 \\
\cline { 2 - 5 } & $\%$ & $\mathbf{1 1 , 4 \%}$ & $\mathbf{1 8 , 0 \%}$ & $17,1 \%$ \\
\hline \multirow{2}{*}{ Entre 3 e 5 anos } & Frequência & 91 & 579 & 670 \\
\cline { 2 - 5 } & $\%$ & $28,1 \%$ & $28,2 \%$ & $28,2 \%$ \\
\hline \multirow{2}{*}{ Entre 5 e 7 anos } & Frequência & 76 & 425 & 501 \\
\cline { 2 - 5 } & $\%$ & $\mathbf{2 3 , 5 \%}$ & $\mathbf{2 0 , 7 \%}$ & $21,1 \%$ \\
\hline \multirow{2}{*}{ Mais de 7 anos } & Frequência & 61 & 350 & 411 \\
\cline { 2 - 5 } & $\%$ & $18,8 \%$ & $17,1 \%$ & $17,3 \%$ \\
\hline \multirow{2}{*}{ Total } & Frequência & 324 & 2052 & 2376 \\
\cline { 2 - 5 } & $\%$ & $100,0 \%$ & $100,0 \%$ & $100,0 \%$ \\
\hline
\end{tabular}


Segers et al (2008) encontrou uma relação entre o perfil "Contratado" e alta escolaridade e uma relação entre esse perfis e a predominância de homens. Essas relações não foram observadas no presente estudo.

\section{Grupo 8 - "Arquiteto da Carreira Proteana"}

Esse é o grupo que se distingue por um maior número de variáveis demográficas.

A tabela 53 indica que o grupo "Arquiteto da Carreira Proteana" apresenta menor proporção de indivíduos mais jovens do que o restante da amostra. 13,6\% dos indivíduos deste grupo nasceram entre 1990 e 1994, logo tem idade aproximada de 18 a 22 anos, os demais respondentes apresentam uma proporção maior de indivíduos nessa faixa etária $(17,1 \%)$. No entanto, esse grupo também tem menor proporção de indivíduos mais velhos, nascidos entre 1982 e $1985(26,8 \%)$ do que o restante da amostra (30,4\%). Conclui-se que esse grupo tem maior predominância de indivíduos nascidos entre 1986 e 1989, ou seja, com idade aproximada de 23 a 26 anos $(59,7 \%)$, do que o restante da amostra $(52,6 \%)$.

Tabela 53 - Tabulação cruzada: "Arquiteto da Carreira Proteana" e ano de Nascimento

\begin{tabular}{|c|c|c|c|c|}
\hline \multicolumn{2}{|c|}{ Ano de Nascimento } & $\begin{array}{c}\text { Arquiteto da } \\
\text { Carreira Proteana }\end{array}$ & $\begin{array}{c}\text { Demais } \\
\text { respondentes }\end{array}$ & Total \\
\hline $\mathbf{1 9 8 2 - 1 9 8 5}$ & Frequência & 144 & 558 & 702 \\
\hline & $\%$ & $\mathbf{2 6 , 8 \%}$ & $\mathbf{3 0 , 4 \%}$ & $29,5 \%$ \\
\hline $\mathbf{1 9 8 6 - 1 9 8 9}$ & Frequência & 321 & 966 & 1287 \\
\hline & $\%$ & $\mathbf{5 9 , 7 \%}$ & $\mathbf{5 2 , 6 \%}$ & $54,2 \%$ \\
\hline $\mathbf{1 9 9 0 - 1 9 9 4}$ & Frequência & 73 & 314 & 387 \\
\hline & $\%$ & $\mathbf{1 3 , 6 \%}$ & $\mathbf{1 7 , 1 \%}$ & $16,3 \%$ \\
\hline Total & Frequência & 538 & 1838 & 2376 \\
\hline & $\%$ & $100,0 \%$ & $100,0 \%$ & $100,0 \%$ \\
\hline
\end{tabular}

Em relação à escolaridade, observa-se maior nível escolar entre os "arquitetos da carreira proteana" do que os demais grupos. Existe uma proporção maior de pós-graduados $(24,2 \%)$ do que no restante da amostra $(20,3 \%)$ e uma proporção menor de pessoas que cursaram até o ensino fundamental/médio $(4,5 \%)$ do que no restante da amostra $(9 \%)$, conforme mostra a tabela 54. Segers et al (2008) também encontraram maior presença de indivíduos de alta escolaridade nesse grupo. 
Tabela 54 - Tabulação cruzada: "Arquiteto da carreira proteana" e escolaridade

\begin{tabular}{|c|c|c|c|c|}
\hline \multicolumn{2}{|c|}{ Escolaridade } & $\begin{array}{c}\text { "Arquiteto da } \\
\text { Carreira Proteana" }\end{array}$ & $\begin{array}{c}\text { Demais } \\
\text { respondentes }\end{array}$ & Total \\
\hline Ensino Fundamental / & Frequência & 24 & 166 & 190 \\
\cline { 2 - 5 } Médio & $\%$ & $\mathbf{4 , 5 \%}$ & $\mathbf{9 , 0 \%}$ & $8,0 \%$ \\
\hline \multirow{2}{*}{ Ensino Superior } & Frequência & 384 & 1299 & 1683 \\
\cline { 2 - 5 } & $\%$ & $71,4 \%$ & $70,7 \%$ & $70,8 \%$ \\
\hline \multirow{2}{*}{ Pós-Graduação } & Frequência & 130 & 373 & 503 \\
\cline { 2 - 5 } & $\%$ & $\mathbf{2 4 , 2 \%}$ & $\mathbf{2 0 , 3 \%}$ & $21,2 \%$ \\
\hline \multirow{2}{*}{ Total } & Frequência & 538 & 1838 & 2376 \\
\cline { 2 - 5 } & $\%$ & $100,0 \%$ & $100,0 \%$ & $100,0 \%$ \\
\hline
\end{tabular}

Os "Arquitetos da carreira proteana" também são mais frequentemente solteiros $(86,4 \%)$ do que o restante da amostra $(82,9 \%)$, conforme indica tabela 55 .

Tabela 55 - Tabulação cruzada: "Arquiteto da carreira proteana" e estado civil

\begin{tabular}{|c|c|c|c|c|}
\hline \multicolumn{2}{|c|}{ Estado Civil } & $\begin{array}{c}\text { Arquiteto da } \\
\text { Carreira Proteana }\end{array}$ & $\begin{array}{c}\text { Demais } \\
\text { respondentes }\end{array}$ & Total \\
\hline \multirow{2}{*}{ Solteiro } & Frequência & 465 & 1523 & 1988 \\
\cline { 2 - 5 } & $\%$ & $\mathbf{8 6 , 4 \%}$ & $\mathbf{8 2 , 9 \%}$ & $83,7 \%$ \\
\hline $\begin{array}{c}\text { Casado/União } \\
\text { Estável / Divorciado }\end{array}$ & Frequência & 73 & 315 & 388 \\
\cline { 2 - 5 } Total & $\%$ & $\mathbf{1 3 , 6 \%}$ & $\mathbf{1 7 , 1 \%}$ & $16,3 \%$ \\
\cline { 2 - 5 } & Frequência & 538 & 1838 & 2376 \\
\cline { 2 - 5 } & $\%$ & $100,0 \%$ & $100,0 \%$ & $100,0 \%$ \\
\hline
\end{tabular}

Em relação à renda média individual, observa-se que os arquitetos da carreira proteana tem renda superior aos demais grupos, sendo que 46,3\% tem renda superior a 3 salários mínimos enquanto essa proporção é de apenas $35,8 \%$ entre os demais respondentes. A renda média mensal familiar também segue o mesmo padrão. Este grupo apresenta renda familiar superior aos demais, sendo que $41,1 \%$ dos indivíduos do grupo "Arquiteto da Carreira Proteana" tem renda familiar superior a 10 salários mínimos enquanto nos demais grupos apenas 33,3\% tem essa faixa de renda.

Tabela 56 - Tabulação cruzada: "Arquiteto da Carreira Proteana" e renda individual

\begin{tabular}{|c|c|c|c|c|}
\hline \multicolumn{2}{|c|}{ Renda Média Individual } & $\begin{array}{c}\text { Arquiteto da } \\
\text { Carreira Proteana }\end{array}$ & $\begin{array}{c}\text { Demais } \\
\text { respondentes }\end{array}$ & Total \\
\hline \multirow{2}{*}{ Sem rendimento } & Frequência & 16 & 114 & 130 \\
\cline { 2 - 5 } & $\%$ & $\mathbf{3 , 0 \%}$ & $\mathbf{6 , 2 \%}$ & $5,5 \%$ \\
\hline \multirow{2}{*}{ Até R\$ 622,00 } & Frequência & 31 & 143 & 174 \\
\cline { 2 - 5 } & $\%$ & $\mathbf{5 , 8 \%}$ & $\mathbf{7 , 8 \%}$ & $7,3 \%$ \\
\hline \multirow{2}{*}{ entre R\$ 622,00 e R\$ 1.244,00 } & Frequência & 126 & 567 & 693 \\
\cline { 2 - 5 } & $\%$ & $\mathbf{2 3 , 4 \%}$ & $\mathbf{3 0 , 8 \%}$ & $29,2 \%$ \\
\hline entre R\$ 1.244,00 e R\$ & Frequência & 116 & 356 & 472 \\
\hline
\end{tabular}




\begin{tabular}{|c|c|c|c|c|}
\hline \multicolumn{2}{|c|}{ Renda Média Individual } & $\begin{array}{c}\text { Arquiteto da } \\
\text { Carreira Proteana }\end{array}$ & $\begin{array}{c}\text { Demais } \\
\text { respondentes }\end{array}$ & Total \\
\hline $\mathbf{1 . 8 6 6 , 0 0}$ & $\%$ & $21,6 \%$ & $19,4 \%$ & $19,9 \%$ \\
\hline entre R\$ 1.866,00 e R\$ & Frequência & 123 & 344 & 467 \\
\cline { 2 - 5 } $\mathbf{3 . 1 1 0 , 0 0}$ & $\%$ & $\mathbf{2 2 , 9 \%}$ & $\mathbf{1 8 , 7 \%}$ & $19,7 \%$ \\
\hline entre R\$ 3.110,00 e R\$ & Frequência & 110 & 269 & 379 \\
\cline { 2 - 2 } & $\%$ & $\mathbf{2 0 , 4 \%}$ & $\mathbf{1 4 , 6 \%}$ & $16,0 \%$ \\
\hline \multirow{2}{*}{ Mais de R\$ 6.220,00 } & Frequência & 16 & 45 & 61 \\
\cline { 2 - 5 } & $\%$ & $\mathbf{3 , 0 \%}$ & $\mathbf{2 , 4 \%}$ & $2,6 \%$ \\
\hline \multirow{2}{*}{ Total } & Frequência & 538 & 1838 & 2376 \\
\cline { 2 - 5 } & $\%$ & $100,0 \%$ & $100,0 \%$ & $100,0 \%$ \\
\hline
\end{tabular}

Tabela 57 - Tabulação cruzada: "Arquiteto da Carreira Proteana" e renda familiar

\begin{tabular}{|c|c|c|c|c|}
\hline \multicolumn{2}{|c|}{ Renda Média Familiar } & $\begin{array}{c}\text { Arquiteto da } \\
\text { Carreira Proteana }\end{array}$ & $\begin{array}{c}\text { Demais } \\
\text { respondentes }\end{array}$ & Total \\
\hline \multirow{2}{*}{ Até R\$ 1.244,00 } & Frequência & 31 & 146 & 177 \\
\cline { 2 - 5 } & $\%$ & $\mathbf{5 , 8 \%}$ & $\mathbf{7 , 9 \%}$ & $7,4 \%$ \\
\hline entre R\$ 1.244,00 e R\$ & Frequência & 81 & 336 & 417 \\
\cline { 2 - 5 } $\mathbf{2 . 4 8 8 , 0 0}$ & $\%$ & $\mathbf{1 5 , 1 \%}$ & $\mathbf{1 8 , 3 \%}$ & $17,6 \%$ \\
\hline entre R\$ 2.448,00 e R\$ & Frequência & 205 & 744 & 949 \\
\cline { 2 - 5 } $\mathbf{6 . 2 2 0 , 0 0}$ & $\%$ & $\mathbf{3 8 , 1 \%}$ & $\mathbf{4 0 , 5 \%}$ & $39,9 \%$ \\
\hline entre R\$ 6.220,00 e R\$ & Frequência & 131 & 395 & 526 \\
\cline { 2 - 5 } $\mathbf{1 2 . 4 4 0 , 0 0}$ & $\%$ & $\mathbf{2 4 , 3 \%}$ & $\mathbf{2 1 , 5 \%}$ & $22,1 \%$ \\
\hline \multirow{2}{*}{ Mais de R\$ 12.440 } & Frequência & 90 & 217 & 307 \\
\cline { 2 - 5 } & $\%$ & $\mathbf{1 6 , 7 \%}$ & $\mathbf{1 1 , 8 \%}$ & $12,9 \%$ \\
\hline \multirow{2}{*}{ Total } & Frequência & 538 & 1838 & 2376 \\
\cline { 2 - 5 } & $\%$ & $100,0 \%$ & $100,0 \%$ & $100,0 \%$ \\
\hline
\end{tabular}

O grupo "Arquiteto da Carreira Proteana" tem maior proporção de indivíduos trabalhando atualmente $(86,2 \%)$ do que os demais respondentes $(81,5 \%)$.

Tabela 58 - Tabulação cruzada: "Arquiteto da Carreira Proteana" e presença de trabalho atual

\begin{tabular}{|c|c|c|c|c|}
\hline \multicolumn{2}{|c|}{ Trabalha atualmente } & $\begin{array}{c}\text { Arquiteto da } \\
\text { Carreira Proteana }\end{array}$ & $\begin{array}{c}\text { Demais } \\
\text { respondentes }\end{array}$ & Total \\
\hline Não trabalha & Frequência & 74 & 340 & 414 \\
\hline & $\%$ & $\mathbf{1 3 , 8 \%}$ & $\mathbf{1 8 , 5 \%}$ & $17,4 \%$ \\
\hline Trabalha & Frequência & 464 & 1498 & 1962 \\
\hline & $\%$ & $\mathbf{8 6 , 2 \%}$ & $\mathbf{8 1 , 5 \%}$ & $82,6 \%$ \\
\hline Total & Frequência & 538 & 1838 & 2376 \\
\hline & $\%$ & $100,0 \%$ & $100,0 \%$ & $100,0 \%$ \\
\hline
\end{tabular}

O grupo "Arquiteto da Carreira Proteana" apresenta maior quantidade de pessoas em cargos de gestão $(18,2 \%)$ do que os demais respondentes $(14,1 \%)$, maior quantidade de trainees $(7,1 \%)$ do que o restante da amostra $(4,8 \%)$ e menor quantidade de estagiários $(15,8 \%)$ 
quando comparado ao restante da amostra $(18,4 \%)$, conforme indica a tabela 59. O estudo de Segers et al (2008) também apresentou um predomínio de pessoas em posições de gestão nesse grupo.

Tabela 59 - Tabulação cruzada: "Arquiteto da Carreira Proteana" e cargo

\begin{tabular}{|c|c|c|c|c|}
\hline \multicolumn{2}{|l|}{ Cargo } & $\begin{array}{c}\text { Arquiteto da } \\
\text { Carreira Proteana }\end{array}$ & $\begin{array}{c}\text { Demais } \\
\text { respondentes }\end{array}$ & Total \\
\hline \multirow{2}{*}{ Diretor / Gerente } & Frequência & 21 & 51 & 72 \\
\hline & $\%$ & $3,9 \%$ & $2,8 \%$ & $3,0 \%$ \\
\hline \multirow{2}{*}{$\begin{array}{c}\text { Coordenador / Supervisor / } \\
\text { Consultor }\end{array}$} & Frequência & 77 & 207 & 284 \\
\hline & $\%$ & $14,3 \%$ & $11,3 \%$ & $12,0 \%$ \\
\hline \multirow{2}{*}{$\begin{array}{c}\text { Analista / Auxiliar / } \\
\text { Assistente }\end{array}$} & Frequência & 263 & 936 & 1199 \\
\hline & $\%$ & $48,9 \%$ & $50,9 \%$ & $50,5 \%$ \\
\hline \multirow{2}{*}{ Trainee } & Frequência & 38 & 88 & 126 \\
\hline & $\%$ & $7,1 \%$ & $4,8 \%$ & $5,3 \%$ \\
\hline \multirow{2}{*}{ Estagiário } & Frequência & 85 & 338 & 423 \\
\hline & $\%$ & $15,8 \%$ & $18,4 \%$ & $17,8 \%$ \\
\hline \multirow{2}{*}{ Outro } & Frequência & 54 & 218 & 272 \\
\hline & $\%$ & $10,0 \%$ & $11,9 \%$ & $11,4 \%$ \\
\hline \multirow{2}{*}{ Total } & Frequência & 538 & 1838 & 2376 \\
\hline & $\%$ & $100,0 \%$ & $100,0 \%$ & $100,0 \%$ \\
\hline
\end{tabular}

Conclui-se que os "Arquitetos da Carreira Proteana" tem maior proporção de indivíduos com idade entre 23 e 26 anos, de solteiros e de indivíduos com alta escolaridade. Eles possuem alta renda individual e familiar e possuem vínculo de trabalho com mais frequência do que os demais respondentes. Ocupam com maior frequência cargos de liderança como, diretor, gerente, coordenador, supervisor, consultor, e o cargo de trainee do que o restante da amostra.

O fato de o respondente ter ou não filhos e tempo de uso da internet foram variáveis investigadas que não tiveram associação estatisticamente significante com nenhum perfil de carreira investigado. 


\section{CONSIDERAÇÕES FINAIS}

Esse capítulo consolida os resultados desse estudo trazendo discussões e reflexões sobre os principais resultados da pesquisa. Além disso, serão apresentadas as limitações da pesquisa, sugestões para estudos futuros e recomendações para os atores de carreira e para as organizações.

\subsection{Considerações finais}

O presente trabalho teve como objetivo identificar o perfil de carreira predominante entre os jovens da Geração Y. Para isso, contou com uma amostra de 2.376 respondentes válidos, o que viabilizou as análises estatísticas necessárias e a obtenção das respostas às questões de pesquisa propostas.

A amostra foi formada por indivíduos entre 18 e 30 anos, que possuem no mínimo um ano de experiência profissional e que se dispuseram a responder o questionário enviado pela empresa Nextview. Os respondentes são predominantemente jovens entre 22 e 28 anos, solteiros (84\%) e sem filhos (93\%), com maior presença de mulheres (57\%) e de indivíduos de alta escolaridade. Mais da metade dos respondentes possuem renda individual superior à média do país (IBGE, 2012). Considerando que a renda familiar é superior a renda individual e que a maioria dos respondentes é solteira sugere-se que o excedente financeiro é oferecido pelos pais. A alta renda familiar indica que a amostra é composta por jovens pertencentes predominantemente (75\%) as classes A e B (ABEP, 2012).

$50 \%$ dos respondentes residem no Estado de São Paulo, 10\% em Minas Gerais, $10 \%$ no Rio de Janeiro e os 30\% restante da amostra reside em diferentes estados do país. Esses jovens dispendem diariamente bastante tempo com a utilização da internet, sendo que $23 \%$ passam mais de 8 horas por dia conectados, corroborando com o rótulo dado por Tapscott (2010) de Geração Internet. 
A maioria dos jovens participantes da pesquisa trabalha atualmente $(82,5 \%)$ e apresenta alta mobilidade entre empregadores, tendo em vista que o tempo médio de emprego, de acordo com a RAIS é de 3,9 anos (DIEESE, 2011) e esse grupo apresentou tempo médio de 1,5 a 2,5 anos. Metade da amostra atua em cargos de analista, auxiliar ou assistente, $18 \%$ são estagiários e $15 \%$ estão em cargos de gestão (Diretor, Gerente, Coordenador, Supervisor, Consultor).

Após a caracterização da amostra, procedeu-se com a validação da escala de atitudes de carreira, analisando a confiabilidade e consistência interna do instrumento. Inicialmente foi utilizada a técnica de Análise Fatorial Exploratória que apresentou bons resultados de confiabilidade, medida pelo alfa de Cronbach, mas indicou baixa comunalidade nas questões 1 e 8, sugerindo baixa adequação para a solução fatorial, e carga cruzada na questão 15, sugerindo que essa variável contribuía para dois fatores diferentes. De Bruin e Buchner (2010) encontraram problemas nas mesmas variáveis.

Uma nova análise fatorial exploratória foi realizada excluindo essas três questões, o que fez com que o questionário não apresentasse nenhum problema de comunalidade ou carga cruzada e gerou um aumento da variância explicada pelo modelo fatorial. $\mathrm{O}$ alfa de Cronbach do questionário reduzido foi de 0,815 , o que afirma a consistência interna do instrumento. Os alfas de Cronbach dos fatores e dos constructos (carreira sem fronteiras e proteana) tiveram resultados superiores a 0,723 , ou seja, superiores ao indicado como limite mínimo por Hair et al (2009) garantindo também a consistência interna de cada dimensão de atitude de carreira. $\mathrm{O}$ modelo fatorial também foi confirmado pela análise paralela (HAYTON et al, 2004).

O modelo de questionário reduzido foi novamente testado pela Análise Fatorial Confirmatória através do software SMART PLS com o uso de modelagem de equações estruturais. Todos os coeficientes padronizados foram superiores a 0,5 indicando que todas as questões se encaixam e contribuem para a explicação do respectivo fator. $\mathrm{O}$ modelo apresentou resultados satisfatórios de confiabilidade composta e no alfa de Cronbach.

A matriz de correlação entre os fatores e dimensões da pesquisa também afirmam a validade, tendo em vista que as correlações têm proporções semelhantes às encontradas por Briscoe et al (2006) e Silva (2009). 
Os resultados do presente estudo confirmam os achados de Briscoe et al (2006) e de Silva (2009) de que os constructos de carreira proteana e sem fronteiras são distintos mas correlacionados. Os resultados também confirmam a afirmação de Sullivan e Arthur (2006) de que a mobilidade psicológica e a mobilidade física também são correlacionados mas distintos.

Os resultados apontam que o autodirecionamento é mais relevante para explicar a carreira proteana do que a orientação pelos valores, enquanto a mobilidade psicológica é mais relevante para explicar a carreira sem fronteiras do que a mobilidade física. A importância da mobilidade psicológica confirma o elemento subjetivo da carreira sem fronteiras e a importância da mentalidade sem fronteiras, conforme defendido por Sullivan e Arthur (2006). Conclui-se que a carreira sem fronteiras vai além da mobilidade física.

\section{$\underline{\text { As análises fatoriais exploratória e confirmatória afirmam a validade e confiabilidade }}$}

$\underline{\text { do instrumento utilizado }}$ o que permitiu a continuidade das análises no sentido de atender aos demais objetivos da pesquisa. Essas análises também sugerem que o instrumento é válido para medição dessas atitudes de carreira no Brasil e que o país apresenta resultados semelhantes, quanto às correlações entre as dimensões de carreira, aos Estados Unidos (BRISCOE et al, 2006) e África do Sul (DE BRUIN; BUCHNER, 2010), locais onde pesquisas semelhantes foram conduzidas com resultados comparáveis.

Esse estudo confirma a validade da escala no Brasil, conforme estudo conduzido por Silva (2009), e oferece análises adicionais, pois avalia as quatro dimensões em um único modelo fatorial e utiliza a análise fatorial exploratória e confirmatória, além de uma amostra maior envolvendo indivíduos de todo o país.

Validado o instrumento de pesquisa, o segundo objetivo específico foi atendido: a classificação da amostra de acordo com seus perfis de carreira. Para isso, foi utilizada a análise de agrupamentos não hierárquica, selecionando como sementes as combinações de alta e baixa presença de cada atitude de carreira e os perfis mais prováveis descritos por Briscoe e Hall (2006).

Diversas soluções foram analisadas e a solucão de 8 grupos foi eleita como a mais adequada para atender aos objetivos desse estudo. Essa solução foi escolhida devido à distribuição dos 
indivíduos dentro dos grupos, que indica maior seletividade, e também pelo maior alinhamento dos perfis predominantes com as teorias de geração e carreiras.

A aplicação prática da escala seguida da classificação nos perfis de carreira foi inovadora. Não foram encontrados estudos anteriores que fizeram análises semelhantes, já que os perfis de carreira foram desenvolvidos apenas conceitualmente por Briscoe e Hall (2006). Segers at al (2008) utilizaram os perfis mas não utilizaram as escalas propostas por Briscoe et al (2006) e sim um questionário sobre motivação adaptado as quatro dimensões de carreira.

Foram encontrados cinco grupos descritos por Briscoe e Hall (2006): "Perdido", "Organizacional", "Cidadão Sólido", "Contratado" e "Arquiteto da Carreira Proteana" e três novos grupos, classificados como "Proteano Estável" (alta presença de autodirecionamento e orientação pelos valores, baixa mobilidade psicológica e mobilidade física neutra), "Viajante orientado" (baixo autodirecionamento, alta orientação pelos valores, baixa mobilidade psicológica e alta mobilidade física) e "Buscador" (baixo autodirecionamento, orientação pelos valores neutra, alta mobilidade psicológica e física). O gráfico 5 apresenta a distribuição dos respondentes nos oito grupos.

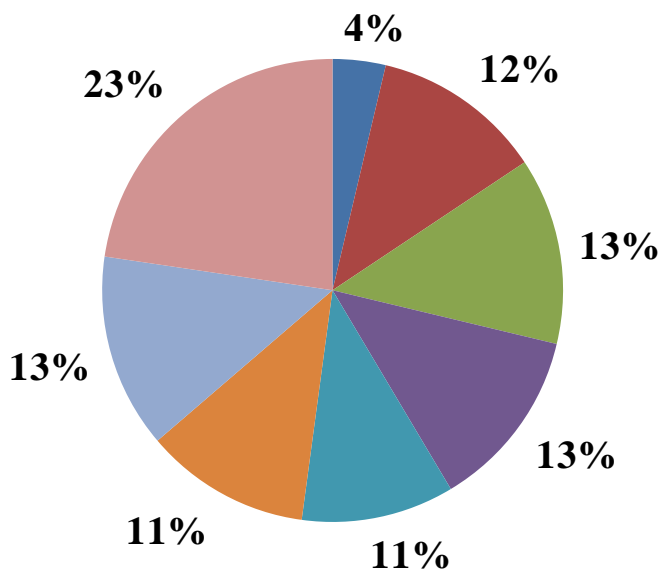

$$
\begin{aligned}
& \text { - Perdido } \\
& \text { - Proteano Está vel } \\
& \text { Viajante Orientado } \\
& \text { Buscador } \\
& \text { - Organiza cional } \\
& \text { Cidadão Sólido } \\
& \text { Contratado } \\
& \text { Arquiteto da Ca rreira } \\
& \text { Proteana }
\end{aligned}
$$

\section{Gráfico 5 - Distribuição dos respondentes entre os 8 perfis de carreira incluindo os novos perfis identificados nesse estudo}

\section{Observa-se no gráfico 5 que o perfil predominante é o "Arquiteto da Carreira proteana"} que compreende $23 \%$ da amostra. Esse é o perfil que apresenta alta presença de todas as atitudes modernas de carreira, confirmando as teorias de geração que dizem que o fato dos 
indivíduos mais jovens se socializarem no ambiente de trabalho moderno, com um mercado de trabalho mais competitivo, globalizado e caracterizado pelas mudanças e velocidade, os leva a adequar seu perfil de carreira a essa realidade (TAPSCOTT, 2010; EDMUNDS; TURNER, 2005; SILVA et al, 2011) e também as teorias de carreira que descrevem a forte influência que esse novo ambiente de trabalho exerce sobre as atitudes de carreira dos indivíduos (BRISCOE et al, 2012; BRISCOE et al, 2006; ARTHUR, 1994; HALL, 2002).

A predominância do perfil "Arquiteto da Carreira Proteana" indica que em sua maioria os jovens buscam autonomia, flexibilidade, aprendizado contínuo, abertura para trabalhar além das fronteiras organizacionais e espaço para movimentação no trabalho.

Esse estilo de trabalho está alinhado aos atributos valorizados pelos jovens ao escolher uma empresa para trabalhar, tais como, desenvolvimento profissional, desafios, boa imagem no mercado, bom ambiente de trabalho e carreira internacional (CIA DE TALENTOS, 2012). O desenvolvimento e o aprendizado decorrentes dos desafios enfrentados são direcionadores das carreiras modernas. A boa imagem no mercado e o bom ambiente de trabalho permitem os relacionamentos além das fronteiras, com a criação de redes de contato interna e externas. Por fim, a carreira internacional está relacionada à alta mobilidade psicológica e física dos jovens, dentro da visão da carreira sem fronteiras.

O fato de o Brasil ter passado por diversas crises econômicas até o fim da década de 90 faz com que seja um país propício para que existam maiores diferenças entre as novas e antigas gerações quanto à carreira (BRISCOE et al, 2009). A maior presença de "Arquitetos da Carreira Proteana" entre os jovens pesquisados pode ter sido influenciada pelo contexto socioeconômico do país. Amaral (2004) descreve como situações de desemprego e de crises financeiras vividas pelos pais afetam o comportamento dos filhos no trabalho, gerando uma relação de menor fidelidade às organizações e maior prioridade à satisfação no trabalho.

O perfil de menor representação é o "Perdido" que é composto por 4\% da amostra. Esse perfil apresenta baixa presença das atitudes de carreira medidas, aproximando-se do perfil tradicional de carreira (ARTHUR, 2004).

Conclui-se, pela análise da distribuição da amostra entre os perfis encontrados, que as novas carreiras são realidade para os jovens brasileiros. No entanto, existe uma menor proporção de 
pessoas com baixas atitudes de carreira em diversas dimensões, indicando que esse é um movimento e ainda não pode ser considerado como fato para todos os indivíduos pesquisados. Ainda existem indivíduos que esperam direcionamento e suporte das organizações em que trabalham (RODRIGUES; GUEST, 2010) ou que não tem condições de direcionar sua própria carreira, por limites educacionais, financeiros ou por problemas de marginalização (INKSON, 2006).

Diferenças regionais e atributos pessoais, tais como idade, educação, gênero e raça, também trazem diferenças entre os grupos geracionais (DENCKER et al, 2008). Foi investigada a associação entre as características demográficas da amostra e a presença de atitudes de carreiras modernas, além da associação entre as características demográficas e os perfis de carreira encontrados.

O quadro 22 sintetiza as associações entre as atitudes de carreira e as características demográficas estatisticamente significantes na amostra estudada. São apresentadas as categorias das variáveis com maior proporção de indivíduos com alta atitude de carreira. Observa-se que o autodirecionamento é mais frequente em indivíduos solteiros, de alta renda individual e cargo. A orientação pelos valores é mais frequente em indivíduos residentes na cidade de São Paulo e que têm menor experiência profissional. A mobilidade psicológica é mais frequente em indivíduos com maior escolaridade, renda individual, renda familiar, anos de experiência profissional e cargo. A mobilidade física é mais frequente em indivíduos entre 23 e 26 anos, mulheres, pessoas de maior renda individual e familiar e que tiveram um grande número de empregadores nos últimos 5 anos.

Quadro 22 - Síntese das vinculações significativas entre atitudes de carreira e características demográficas

\begin{tabular}{|c|c|c|c|c|}
\hline $\begin{array}{c}\text { Ano de } \\
\text { Nascimento }\end{array}$ & AD & OV & MP & MF \\
\hline Gênero & & & $\begin{array}{c}>\text { para pessoas de } \\
\text { idade entre } 23 \text { e } 26 \\
\text { anos }\end{array}$ \\
\hline Escolaridade & & & $\begin{array}{c}>\text { para pessoas de } \\
\text { maior escolaridade }\end{array}$ & $\begin{array}{c}>\text { para pessoas de } \\
\text { maior escolaridade }\end{array}$ \\
\hline Estado Civil & $>$ para solteiros & & $\begin{array}{c}>\text { para pessoas de } \\
\text { alta renda individual }\end{array}$ & $\begin{array}{c}>\text { para pessoas de } \\
\text { alta renda individual }\end{array}$ \\
\hline $\begin{array}{c}\text { Renda } \\
\text { Individual }\end{array}$ & $\begin{array}{c}\text { para pessoas de } \\
\text { alta renda } \\
\text { individual }\end{array}$ & & $\begin{array}{c}>\text { para pessoas de } \\
\text { alta renda familiar }\end{array}$ & $\begin{array}{c}>\text { para pessoas de } \\
\text { alta renda familiar }\end{array}$ \\
\hline Renda Familiar & & $\begin{array}{c}\text { > para residentes em } \\
\text { São Paulo - Capital }\end{array}$ & & \\
\hline Estado/Cidade & & & & \\
\hline
\end{tabular}




\begin{tabular}{|c|c|c|c|c|}
\hline & AD & $\mathbf{O V}$ & MP & MF \\
\hline $\begin{array}{c}\text { Anos de } \\
\text { Experiência } \\
\text { Profissional }\end{array}$ & & $\begin{array}{l}>\text { para pessoas com } \\
\text { pouca experiência }\end{array}$ & $\begin{array}{l}>\text { para pessoas com } \\
\text { mais experiência }\end{array}$ & \\
\hline Cargo & $\begin{array}{l}>\text { para cargos } \\
\text { altos }\end{array}$ & & $>$ para cargos altos & \\
\hline $\begin{array}{c}\text { Número de } \\
\text { empregadores }\end{array}$ & & & & $\begin{array}{c}\text { > para pessoas que } \\
\text { tiveram muitos } \\
\text { empregadores }\end{array}$ \\
\hline
\end{tabular}

Esses resultados foram comparados com pesquisas anteriores (BRISCOE et al, 2006; SILVA, 2009; SEGERS et al, 2008; RIBEIRO et al, 2009) e diversas variáveis tem associações semelhantes. No entanto, o presente estudo analisou um maior número de características e permitiu a investigação da vinculação destas com as atitudes de carreira especificamente para os jovens da Geração Y no Brasil.

O quadro 23 indica as associações entre os perfis de carreira encontrados nesse estudo e as características demográficas estatisticamente significantes. São apresentadas as classes demográficas com maior proporção de indivíduos para cada perfil quando comparado ao restante da amostra. O perfil "Viajante orientado" não apresentou diferença quanto a nenhuma demografia investigada e por isso não está presente no quadro. $\mathrm{O}$ fato de destacar uma determinada classe demográfica não indica que ele seja a maioria dentro do grupo em questão e sim, que nessa faixa ou atributo, esse grupo apresenta maior proporção de respondentes do que o restante da amostra.

Quadro 23 - Síntese das vinculações significativas entre perfis de carreira e características demográficas

\begin{tabular}{|c|c|c|c|c|c|c|c|}
\hline & $\begin{array}{l}\text { Perdi- } \\
\text { do }\end{array}$ & $\begin{array}{c}\text { Proteano } \\
\text { Estável }\end{array}$ & Buscador & $\begin{array}{l}\text { Organiza- } \\
\text { cional }\end{array}$ & $\begin{array}{l}\text { Cidadão } \\
\text { Sólido }\end{array}$ & $\begin{array}{c}\text { Contra- } \\
\text { tado }\end{array}$ & $\begin{array}{c}\text { Arquiteto da } \\
\text { Carreira } \\
\text { Proteana } \\
\end{array}$ \\
\hline $\begin{array}{l}\text { Ano de } \\
\text { Nasci- } \\
\text { mento }\end{array}$ & & $\begin{array}{l}18 \text { e } 22 \\
\text { anos e } 27 \text { a } \\
30 \text { anos }\end{array}$ & & & & & 23 a 26 anos \\
\hline Gênero & & & Mulheres & & Homens & & \\
\hline $\begin{array}{l}\text { Escolari- } \\
\text { dade }\end{array}$ & $\begin{array}{l}\text { Baixa } \\
\text { escolari } \\
\text {-dade }\end{array}$ & & & $\begin{array}{l}\text { Baixa } \\
\text { escolarida- } \\
\text { de } \\
\end{array}$ & & & $\begin{array}{l}\text { Alta } \\
\text { escolaridade }\end{array}$ \\
\hline Estado Civil & & & & & & & Solteiro \\
\hline $\begin{array}{l}\text { Renda } \\
\text { Individual }\end{array}$ & & & $\begin{array}{l}\text { Baixa / } \\
\text { média }\end{array}$ & $\begin{array}{l}\text { Baixa } \\
\text { renda }\end{array}$ & & & Alta renda \\
\hline $\begin{array}{l}\text { Renda } \\
\text { Familiar }\end{array}$ & & & & & $\begin{array}{l}\text { Renda de } \\
\text { até } 2 \\
\text { salários }\end{array}$ & & Alta renda \\
\hline
\end{tabular}




\begin{tabular}{|l|l|l|l|l|l|l|l|}
\hline & $\begin{array}{c}\text { Perdi- } \\
\text { do }\end{array}$ & $\begin{array}{c}\text { Proteano } \\
\text { Estável }\end{array}$ & Buscador & $\begin{array}{c}\text { Organiza- } \\
\text { cional }\end{array}$ & $\begin{array}{c}\text { Cidadão } \\
\text { Sólido }\end{array}$ & $\begin{array}{c}\text { Contra- } \\
\text { tado }\end{array}$ & $\begin{array}{c}\text { Arquiteto da } \\
\text { Carreira } \\
\text { Proteana }\end{array}$ \\
\hline $\begin{array}{l}\text { Estado/ } \\
\text { Cidade }\end{array}$ & & $\begin{array}{l}\text { São Paulo } \\
\text { - Capital e } \\
\text { Sul }\end{array}$ & & & & & \\
\hline $\begin{array}{l}\text { Trabalha } \\
\text { atualmente }\end{array}$ & & & & Não & Não & & Sim \\
\hline $\begin{array}{l}\text { Anos de } \\
\text { experiência } \\
\text { profissional }\end{array}$ & & & & & & $\begin{array}{l}\text { Entre 1 e } \\
\text { 2 anos e } \\
\text { mais de 5 } \\
\text { anos }\end{array}$ & \\
\hline Cargo & & & $\begin{array}{l}\text { Analistas, } \\
\text { Auxiliares } \\
\text { e }\end{array}$ & & & & $\begin{array}{l}\text { Diretores, } \\
\text { Gerentes, } \\
\text { Coordenadores } \\
\text { Supervisores, } \\
\text { Consultores e } \\
\text { Trainees }\end{array}$ \\
\hline $\begin{array}{l}\mathbf{N}^{\circ} \text { de } \\
\text { emprega- } \\
\text { dores }\end{array}$ & & Assistentes & & & & \\
\hline
\end{tabular}

Os resultados da pesquisa indicam que o perfil "Perdido" é caracterizado pela baixa escolaridade e que o perfil "Arquiteto da Carreira Proteana" é caracterizado pela alta escolaridade, alta renda individual e familiar e altos cargos. Dentre os "Arquitetos da Carreira Proteana" existe uma predominância de solteiros, de pessoas com idade entre 23 e 26 anos e de profissionais que estão trabalhando atualmente.

Observa-se, tanto pela análise da associação entre as características demográficas e atitudes de carreira, quanto pela análise entre essas características e os perfis de carreira, que as carreiras modernas estão associadas à alta escolaridade e alta renda, principalmente a carreira sem fronteiras.

O fato de esta geração apresentar maior predomínio do perfil mais moderno de carreira afeta seu comportamento no trabalho (DENCKER et al, 2008). O predomínio desse perfil também modela as normas de comportamento desta geração nas organizações, influenciando as percepções e reações dos demais indivíduos a esse grupo (LAWRENCE; TOLBERT, 2007).

A alta presença de atitudes de carreira sem fronteiras traz um desafio de retenção para as organizações, já que indica maior movimentação entre empregadores. A violação do contrato psicológico de trabalho deve ser evitada pelas empresas, já que diante da insatisfação, existe 
uma tendência de redução do comprometimento organizacional do ator de carreira sem fronteiras (BRISCOE; FINKELSTEIN, 2009).

Com base nesses resultados, é possível verificar a importância do estudo acadêmico das questões geracionais atuais, das novas teorias de carreira e seus impactos na gestão de pessoas no Brasil.

A academia, em sua função de geração do conhecimento, deve iniciar um movimento de ampliação de estudos dos impactos das gerações em diversas áreas do conhecimento. No caso da presente dissertação, buscou-se contribuir nesse sentido com a gestão de pessoas, especificamente com a gestão de carreiras no Brasil.

\subsection{Limitações da pesquisa e sugestões para estudos futuros}

A primeira limitação da pesquisa está relacionada à amostra utilizada nesse estudo, que é não probabilística e intencional. $\mathrm{O}$ acesso ao público alvo da pesquisa e a disponibilidade dos convidados para participar foram os elementos direcionadores na escolha da amostra. Os resultados apresentados não podem ser generalizados para todos os jovens da Geração Y brasileiros, mas o presente estudo concentrou um número expressivo de respondentes que viabilizou as análises estatísticas e fornece evidências importantes sobre as atitudes de carreira desse público.

Como o público alvo teve como base os indivíduos cadastrados em um banco de dados de uma empresa de recrutamento e seleção, ou seja, pessoas que buscaram ou estão buscando um novo emprego, é possível que isso proporcionado uma amostra de indivíduos que tenham maior mobilidade física.

Outra limitação do estudo foi a análise do ponto de vista do indivíduo. Estudos futuros privilegiando a organização como unidade de análise podem aprofundar o conhecimento sobre gerações e novas carreiras nas organizações brasileiras, tendo em vista os perfis de carreira descritos na presente dissertação. Para ampliar esse campo de pesquisa sugere-se a 
realização de estudos empíricos utilizando dados longitudinais, estudos etnográficos e estudos de caso para aprofundamento da compreensão do efeito geracional nas organizações já que o tema é emergente e pouco se conhece sobre o assunto (PARRY; URWIN, 2010; JOSHI et al, 2010).

Na medida em que apenas uma geração é escolhida como objeto de estudo outra limitação de pesquisa é apresentada. Não foi possível comparar os perfis de carreira de indivíduos de diferentes gerações ou avaliar diferenças entre gerações. O estudo de apenas uma geração é sugerido por Parry e Urwin (2010) como uma solução para aprofundamento do tema, de modo a evitar erros metodológicos de estudar a comparação entre gerações sem excluir efeitos de idade e de período. A abordagem comparativa pode orientar estudos futuros sobre o tema.

Seria interessante a realização de estudos conduzidos com o mesmo instrumento de pesquisa para comparação de jovens da Geração Y de diferentes países. Briscoe et al (2012) encontraram divergências entre a percepção de sucesso na carreira entre jovens de diferentes nações. Estudos comparativos sobre perfis de carreira contribuiriam para a análise das gerações em diferentes culturas confirmando ou rejeitando a hipótese de Tapscott (2010) e de Edmunds e Turner (2005) sobre as novas gerações serem globais.

Fica evidente a falta de estudos empíricos que indiquem quais são as gerações atuais no Brasil (VELOSO et al, 2011; PINHO et al, 2011) tendo em vista que os estudos nacionais encontrados utilizam bibliografia internacional para descrição dos anos divisores das gerações e de suas características, logo a necessidade de estudos sobre gerações no país é premente. Inicialmente, existe uma lacuna de estudos sociológicos, tal como o conduzido por Schuman e Scott (1989), nos Estados Unidos, com o levantamento dos fatos históricos relevantes que indicam a divisão das gerações no país.

Em relação ao instrumento de pesquisa sugerem-se estudos que validem a escala de atitudes de carreira proteana e sem fronteiras para pessoas de outras gerações. Essa validação é necessária porque os constructos podem variar de acordo com o estágio de carreira e contexto, pois são atitudes de carreira e não traços de personalidade (BRISCOE et al, 2006). A adequação das perguntas 1, 8 e 15, também necessitam ser reavaliadas em estudos futuros, pois apresentaram problemas na presente dissertação e na pesquisa conduzida por De Bruin e Buchner (2010). 
O campo de carreiras também apresenta vasto espaço de pesquisa no país. Estudos futuros podem analisar se as práticas de gestão de carreira das organizações brasileiras são condizentes com os perfis de carreira presentes nos jovens. Pode ser avaliado também o estágio de adaptação das organizações no processo de mudança diante do novo contrato, tal como proposto por Hall (2002).

Uma última sugestão de estudo é a análise do contexto social e econômico do Brasil para o desenvolvimento das novas carreiras, avaliando se o país apresenta os impactos no mercado de trabalho descritos como base para o nascimento das novas carreiras, tais como, aumento da rotatividade, aumento da flexibilidade, aumento da mão de obra contingente, temporária e com diferentes vínculos de trabalho, maior número de competidores, menor estabilidade, e declínio do número de grandes empresas (ARTHUR et al, 1999; HALL, 2002; RODRIGUES; GUEST, 2010; INKSON, 2006).

Identificando-se a necessidade de aprofundamento e o vasto espaço de pesquisa aqui demonstrado, espera-se que esse estudo sirva como convite aos pesquisadores para desenvolverem novos estudos empíricos sobre gerações e seu impacto sobre a gestão de pessoas e sobre a gestão de carreiras nas organizações brasileiras.

\subsection{Recomendações para as organizações, gestores e atores de carreira}

\section{Recomendações para as organizações e gestores}

Os resultados desse estudo apontam que as novas carreiras são uma realidade para os jovens. É fundamental que as organizações brasileiras reconheçam esses novos perfis de carreira e busquem adaptar seus modelos de gestão de pessoas e de gestão de carreiras de modo a atender necessidades diversas, alinhadas aos diferentes perfis de carreira e diferentes gerações.

Existe uma tendência de valorização de benefícios intangíveis e da busca da realização, desenvolvimento e bem-estar no trabalho (EMPRESAS, 2010). A flexibilidade é palavrachave tendo em vista que mesmo os jovens apresentam diferentes perfis e consequentemente tem diferentes expectativas do papel da organização na gestão de sua carreira. 
O papel da gestão de carreiras é de mediação e fundamental para a manutenção do contrato psicológico garantindo a percepção de justiça e a manutenção do comprometimento organizacional. A forma transacional do contrato psicológico ganha mais peso, conforme descrito por Hall (2002), ou seja, tanto empregado quanto empregador darão continuidade na relação apenas enquanto suas necessidades imediatas forem atendidas. Isso faz com que aumente a necessidade de diálogo entre empregados e empregadores, já que os sistemas sofisticados de carreira e sucessão exigem estabilidade e previsibilidade que são raras no mundo atual (HALL et al, 2012).

As organizações devem desenvolver programas modernos de gestão de carreira que: considerem qualificações, competências e experiências, ofereçam suporte ao desenvolvimento da carreira, promovam aprendizado contínuo, ofereçam direcionamento e ofereçam opções flexíveis em termos de remuneração, benefícios, reconhecimento, desenvolvimento, etc. (BIANCHI; QUISHIDA, 2009; DUTRA, 2010; BARUCH; PEIPERL, 2000; VELOSO, 2009; HALL, 2002; HALL et al, 2012).

Arthur et al (2005) alertam sobre a importância da coerência entre as práticas de Gestão de Pessoas desenvolvidas pela organização e os princípios das novas carreiras e dos novos contratos psicológicos para evitar contradição ou confusão. Na migração para os novos modelos de carreira é essencial que os sistemas de remuneração, recompensa, promoção, benefícios, etc. deem suporte a esse movimento.

Baruch (2004) e Albuquerque (1999) lembram que as práticas de gestão de pessoas são decorrentes da estratégia de gestão de pessoas. $\mathrm{O}$ alinhamento estratégico é fundamental para evitar a contradição descrita por Arthur et al (2005). Os princípios das novas carreiras devem ser considerados na elaboração da estratégia de gestão de pessoas, mantendo também coerência com os objetivos estratégicos da organização.

A carreira organizacional é uma contínua renegociação de contratos psicológicos (BARUCH, 2004) e a gestão de carreiras contribui para o papel de Recursos Humanos de atrair e reter talentos. Práticas de gestão de carreiras consistentes são fundamentais para atender necessidades individuais e engajar os empregados com os objetivos organizacionais. 
O debate sobre as diferenças entre gerações é frequente nas organizações. Os gestores se questionam sobre como atrair, engajar, gerir e reter os jovens da Geração Y e observam diferenças entre essas gerações e as anteriores, geralmente se comparando consigo mesmos quando jovens. Observar o diferente contexto que esses jovens se desenvolveram e estão encontrando no mercado de trabalho, permite a compreensão de que eles podem ter diferentes expectativas de carreira e uma relação diferente com o trabalho. A teoria de gerações traz essa contribuição e os perfis de carreira atestam que existem diversas possibilidades e atitudes de carreira.

Tanto a teoria de gerações quanto os perfis de carreira fazem um convite para os gestores e jovens se engajarem em um diálogo que permita a troca sobre suas percepções e expectativas quanto ao trabalho e a carreira, considerando que existe uma infinidade de possibilidades.

\section{Recomendações para os atores de carreira}

O presente estudo traz diversas recomendações e sugestões para os atores de carreira. Conhecer as novas carreiras e seu perfil de carreira é importante para explorar os desafios pessoais, direcionar o desenvolvimento e aproveitar oportunidades que se apresentam.

É importante reconhecer que o desenvolvimento da carreira tem como foco o aprendizado e a criação de redes fora da organização, envolvendo familiares e relacionamentos pessoais (BRISCOE; HALL, 2006; ARTHUR, 2004).

Conhecer os valores pessoais, insistir em esforços de autoconhecimento e autoinvestigação é importante para trilhar uma carreira moderna. O grande número de opções de trabalho, tais como, locais, indústrias, atividades e empregadores, pode trazer confusão se as escolhas não forem direcionadas pelos valores pessoais e por um senso de autonomia e responsabilidade em relação à própria carreira.

Uma das principais contribuições provenientes das novas teorias de carreira ao ator de carreira é o reconhecimento de seu papel de protagonista em sua história profissional, além da importância das decisões conscientes em relação ao seu próprio desenvolvimento. 


\section{REFERÊNCIAS}

Associação Brasileira de Empresas de Pesquisa - ABEP. Critério de Classificação

Econômica Brasil. Disponível em: <http://www.abep.org/novo/FileGenerate.ashx?id=257>. Acesso em: 2/06/2012.

ALBUQUERQUE, Lindolfo G. Estratégias de Recursos Humanos e competitividade. In: VIEIRA, Marcelo Milano Falcão; OLIVEIRA, Lúcia Maria Barbosa de Oliveira (Org.). Administração contemporânea: perspectivas estratégicas. São Paulo: Atlas, 1999.

AMARAL, Sofia Esteves do. Virando gente grande: como orientar os jovens em início de carreira. São Paulo: Gente, 2004.

ARTHUR, Michael. B. The Boundaryless Career: a new perspective for organizational inquiry. Journal of Organizational Behavior. n. 4, v. 15, p. 295-306, 1994.

ARTHUR, Michael B.; ROUSSEAU, Denise M. The Boundaryless career: a new employment principle for a new organizational era. Nova York: Oxford University Press, 1996.

ARTHUR, Michael B. et al. Intelligent Enterprise, Intelligent Career. The Academy of Management Executive. n. 4, v. 9, p. 7-20, 1995.

ARTHUR, Michael B. et al. The new careers: individual action and economic change. Londres: Sage Publications, 1999.

BARUCH, Yehuda. Managing Careers: Theory and Practice. Harlow: Pearson Education. 2004.

BARUCH, Yehuda; PEIPERL, Maury. Carrer Management Practices: an empirical survey and implications. Human Resources Management. n. 4, v. 39, p. 347-366, 2000.

BIANCHI, Eliane Maria Pires Giavina; QUISHIDA, Alessandra. Gestão Estratégica de Carreiras. In: ALBUQUERQUE, Lindolfo G.; LEITE, Nildes Pitombo (Org.). Gestão de Pessoas: perspectivas e estratégias. São Paulo: Atlas, 2009.

BAUMAN, Zygmunt. O amor líquido: sobre a fragilidade dos laços humanos. Rio de Janeiro: Jorge Zahar, 2004.

BENSON, John; BROWN, Michelle. Generations at work: are there differences and do they matter? The International Journal of Human Resource Management. n. 9, v. 22, p. 1843$1865,2011$.

BRISCOE, Jon P; HALL, Douglas T. The interplay of boundaryless and protean careers: Combinations and implications. Journal of Vocational Behaviour. n. 1, v. 69, p. 4-18, Ago. 2006. 
BRISCOE, Jon P. et al. Protean and boundaryless careers: An empirical exploration. Journal of Vocational Behaviour. n. 1, v. 69, p. 30-47, Ago. 2006.

BRISCOE, Jon P.; FINKELSTEIN, Lisa M. The "new career" and organizational commitment: Do boundaryless and protean career attitudes make a difference? Career Development International. n. 3, v. 14, p. 242-260, 2009.

BRISCOE, Jon P. et al. Careers around the world: individual and contextual perspectives. Nova York: Routledge, 2012.

CAPPELLI, Peter. Will there really be a labor shortage? Human Resource Management. n. 2, v. 44, p. 143-149, 2005.

CASADO, Tania. Comportamento Organizacional: Fundamentos para a Gestão de Pessoas. In: SANTOS, Rubens da Costa (Org.). Manual de Gestão Empresarial: Conceitos e Aplicações nas Empresas Brasileiras. São Paulo: Atlas, 2007.

CAVAZOTTE, Flávia de Souza Costa Neves et al. Relações de Trabalho Contemporâneas e as Novas Gerações Produtivas: Renovadas ou Antigos Ideais? In: Encontro Nacional da Associação Nacional dos Programas de Pós-Graduação em Administração - ENANPAD, 34., 2010, Rio de Janeiro. Anais... Rio de Janeiro: ANPAD, 2010.

CHUDZIKOWSKI, Katharina et al. Culture and Context: Understanding Their Influence Upon Careers. In: BRISCOE, Jon P. et al (Eds.). Careers around the world: individual and contextual perspectives. Nova York: Routledge, 2012.

CIA DE TALENTOS. Disponível em: <http://ciadetalentos.tempsite.ws/esj2010/>. Acesso em: 19/02/2011.

CIA DE TALENTOS. Disponível em: <http://www.ciadetalentos.com.br/esj/resultados1.html>. Acesso em: 01/05/2012.

COIMBRA, Rosângela Gamba Crédico de; SCHIKMANN, Rosane. A geração net. In: Encontro Nacional da Associação Nacional dos Programas de Pós-Graduação em Administração - ENANPAD, 25., 2001, Campinas. Anais.... Campinas: ANPAD, 2001.

COLLINS, Mary Hair et al. The Older-Worker - Younger-Supervisor Dyad: A Test of the Reverse Pygmalion Effect. Human Resource Development Quarterly. n. 1, v. 20, p. 21-41, 2009.

COSTA, Luciano Venelli. A relação entre a percepção de sucesso na carreira e o comprometimento organizacional: um estudo entre professores de universidades privadas selecionadas da grande São Paulo. 2011. Tese (Doutorado em Administração) - Faculdade de Economia, Administração e Contabilidade, Universidade de São Paulo, São Paulo, 2011. Disponível em: <http://www.teses.usp.br/teses/disponiveis/12/12139/tde-24022011-202406/>. Acesso em: 3/02/2012. 
DE BRUIN, Gideon P.; BUCHNER, Morné. Factor and item response theory analysis of the Protean and Boundaryless Career Attitude Scales. SA Journal of Industrial Psychology/SA. n. 36(2), p. 1-11, 2010.

DENCKER, John C. et al. Employee benefits as context for intergenerational conflict. Human Resource Management Review. n. 2, v. 17, p. 208-220, 2007.

DENCKER, John C. et al. Towards a theoretical framework linking generational memories to workplace attitudes and behaviors. Human Resource Management Review. n. 3, v. 18, p. 180-187, 2008.

Departamento Intersindical de Estatística e Estudos Socioeconômicos - DIEESE. Rotatividade e flexibilidade no mercado de trabalho. São Paulo, 2011. Disponível em: < http://www.dieese.org.br/livroRotatividade11.pdf>. Acesso em: 13/05/2012.

DUTRA, Joel S. (Org.). Gestão de carreiras na empresa contemporânea. São Paulo: Atlas, 2010.

EDMUNDS, June; TURNER, Bryan S. Global generations: social change in the twentieth century. The British Journal of Sociology. n. 4, v. 56, 2005.

EMPRESAS dos sonhos e outras aspirações dos jovens. HSM Management. São Paulo: n. 81, p. 42-54, Jul./Ago. 2010.

FEIXA, Carles; LECCARDI, Carmen. O conceito de geração nas teorias sobre juventude. Sociedade \& Estado. Brasília, n. 2, v. 25, mai-ago 2010.

FISCHER, André Luís; ALBUQUERQUE, Lindolfo Galvão. (Org.). Delphi RH 2010 Tendências em Gestão de Pessoas nas Empresas Brasileiras. Edição confirmatória. São Paulo: FIA/PROGEP, 2011.

FLEURY, Maria Tereza L.; FISCHER, Rosa Maria. Relações de trabalho e políticas de gestão: uma história das questões atuais. Revista de Administração. São Paulo, n. 4, v. 27, p. 5-15, out./dez. 1992.

FORAY, Dominique; LUNDVALL, Bengt-Aake. From Economics of Knowledge to the Learning Economy. In: Employment and Growth in the Knowledge-Based Economy. Paris: OECD, 1996.

HAIR, Joseph F. et al. Análise multivariada de dados. 6. ed. Porto Alegre: Bookman, 2009.

HALL, Douglas T. Careers in and out of organizations. Londres: Sage, 2002.

HALL, Douglas T. et al. Implications for the Management of People and Organizations. In: BRISCOE, Jon P. et al (Eds.). Careers around the world: individual and contextual perspectives. Nova York: Routledge, 2012. 
HAYTON, James C. et al. Factor retention decisions in exploratory factor analysis: a tutorial on parallel analysis. Organizational Research Methods. n. 7, p. 191-205, 2004.

HOSFTEDE, Geert. Cultures and Organizations: Software of the Mind. 2. ed. Nova York: Mc Graw Hill, 1997.

INKSON, Kerr. Protean and boundaryless careers as metaphors. Journal of Vocational Behavior. n. 1, v. 69, p. 48-63, Ago 2006.

Instituto Brasileiro de Geografia e Estatística - IBGE. Características da população - Censo demográfico de 2000. Disponível em: <http://www.ibge.gov.br/ibgeteen/pesquisas/demograficas.html>. Acesso em: 07/05/2011.

Instituto Brasileiro de Geografia e Estatística - IBGE. Sinopse dos Resultados do Censo 2010. Disponível em: <http://www.censo2010.ibge.gov.br/sinopse/webservice>. Acesso em: 2/06/2012.

IKEDA, Ana Akemi et al. O uso de coortes em segmentação de marketing. O\&S. n. 44, v.15, Jan./Mar. 2008.

JOSHI, Aparna et al. Unpacking Generational Identities in Organizations. Academy of Management Review. n. 3, v. 35, p. 392-414, 2010.

KANFER, Ruth; ACKERMAN, Philip L. Aging, Adult Development, and Work Motivation. Academy of Management Review. n. 3, v. 29, p. 440-458, 2004.

LAWRENCE, Barbara S; TOLBERT, Pamela S. Organizacional demography and individual careers: structure, norms and outcomes. In: GUNZ, Hugh; PEIPERL, Maury (Eds.). Handbook of Career Studies. Thousand Oaks: Sage, 2007.

LIPKIN, Nicole; PERRYMORE, April. A Geração Y no Trabalho: Como lidar com a força de trabalho que influenciará definitivamente a cultura da sua empresa. Rio de Janeiro: Elsevier, 2010.

LIPPMANN, Stephen. Rethinking risk in the new economy: Age and cohort effects on unemployment and re-employment. Human Relations. n. 9, v. 61, p. 1259-1292, 2008.

LIU, Shuang. Cultures within Culture: Unity and Diversity of Two Generations of Employees in State-Owned Enterprises. Human Relations. n. 4, v. 56, p. 387-417, 2003.

LOMBARDIA, Pilar García et al. Politicas para dirigir a los nuevos profesionales motivaciones y valores de la generacion Y. IESE Business School - Universidad de Navarra - Documento de investigación DI-753. Mai./2008. Disponível em <http://www.iesep.com/Descargas/spdf/Gratuitos/R130.pdf>. Acesso em 09/02/2010.

MANNHEIM, Karl. El problema de las generaciones. REIS - Revista Española de Investigaciones Sociológicas, n. 62, pp. 193-242, Abr-Jun 1993. 
MARCONI, Marina de Andrade; LAKATOS, Eva Maria. Fundamentos da metodologia científica. 5. ed. São Paulo: Atlas, 2003.

MARTINS, Gilberto de Andrade. Manual para elaboração de monografias e dissertações. 3. ed. São Paulo: Atlas, 2007.

MARTINS, Gilberto de Andrade; THEÓPHILO, Carlos Renato. Metodologia de investigação científica para ciências sociais aplicadas. 2. ed. São Paulo: Atlas, 2009.

MOORE, Celia et al. Tracing the historical roots of career theory in management and organizational studies. In: GUNZ, Hugh; PEIPERL, Maury (Eds.). Handbook of Career Studies. Thousand Oaks: Sage, 2007.

NAKATA, Lina Eiko. As expectativas de aprendizagem nas organizações que buscam se destacar pelo clima organizacional. 2009. Dissertação (Mestrado em Administração) Faculdade de Economia, Administração e Contabilidade, Universidade de São Paulo, São Paulo, 2009. Disponível em: <http://www.teses.usp.br/teses/disponiveis/12/12139/tde01122009-211530/>. Acesso em: 14/03/2011.

NOGUEIRA, Alexandre Santana et al. Impacto das Diferenças Geracionais no Comprometimento dos Oficiais Intendentes com a Organização Comando da Aeronáutica. In: Encontro Nacional da Associação Nacional dos Programas de Pós-Graduação em Administração - ENANPAD, 35., 2011, Rio de Janeiro. Anais... Rio de Janeiro: ANPAD, 2011.

PARRY, Emma; URWIN, Peter. Generational differences in work values: A review of theory and evidence. International Journal of Management Reviews. p. 1-18, 2010.

PRALONG, Jean. L'image du travail selon la génération $Y$ : Une comparaison intergénérationnelle conduite sur 400 sujets grâce à la technique des cartes cognitive. Revue internationale de Psychosociologie. v. 16, p. 109-134, 2010.

PINHO, Magda Sales et al. Estudos sobre a produção científica pautada na Geração Y - uma meta-análise. In: Encontro de Gestão de Pessoas e Relações de Trabalho - EnGPR, 3., 2011, João Pessoa. Anais... João Pessoa: ANPAD, 2011.

QUINN, James Brian. Intelligent Enterprise: a new paradigm for a new era. Nova York: Free Press, 1992.

RIBEIRO, Rodolfo da et al. Carreiras de Profissionais de Marketing com Atuação em São Paulo: Uma Avaliação da Atitude Proteana e das Condições do Ambiente para o Desenvolvimento de uma Carreira Moderna. In: Encontro Nacional da Associação Nacional dos Programas de Pós-Graduação em Administração - ENANPAD, 33., 2009. Anais... São Paulo: ANPAD, 2009.

RODRIGUES, Ricardo A.; GUEST, David. Have careers become boundaryless? Human Relations. n. 8, v. 63, p. 1157-1175, 2010. 
ROUSSEAU, Denise M. Psychological contracts in organizations: understanding unwritten agreements. Thousand Oaks: Sage, 1995.

SARGENT, Leisa D.; DOMBERGER, Shelley R. Exploring the development of a protean career orientation: values and image violations. Career Development International. n. 6, v. 12, p. 545-564, 2007.

SCALABRIN, Ana Carla. Carreiras sem fronteiras e trajetórias descontínuas: um estudo descritivo sobre decisões de opt-out. 2008. Dissertação (Mestrado em Administração) Faculdade de Economia, Administração e Contabilidade, Universidade de São Paulo, São Paulo, 2008. Disponível em: <http://www.teses.usp.br/teses/disponiveis/12/12139/tde03092008-110945/>. Acesso em: 28/05/2011.

SEGERS, Jesse et al. Protean and boundaryless careers: A study on potential motivators. Journal of Vocational Behavior. n. 2, v. 73, p. 212-230, Out. 2008.

Society for Human Resource Management - SHRM. Workplace Forecast: the top workplace trends according to HR professionals. Fev. 2011. Disponível em: < http://www.shrm.org/research/futureworkplacetrends/documents/11-014wpf_posting_6.pdf>. Acesso em: 20/05/2011.

SCHUMAN, Howard, SCOTT, Jacqueline. Generations and Collective Memories. American Sociological Review. n. 3, v. 54, p. 359-381, 1989.

SILVA, Jefferson de Alcantara. Estudo Comparativo dos Modelos de Carreira Proteana e Carreira sem Fronteiras por meio de Escalas de Atitudes. 2009. Dissertação (Mestrado em Administração) - Programa de Pós-Graduação em Administração da Universidade Federal de Uberlândia. Uberlândia, 2009.

SILVA, Rodrigo Cunha da et al. Carreiras: Novas ou Tradicionais? Um Estudo com Profissionais Brasileiros. In: Encontro Nacional da Associação Nacional dos Programas de Pós-Graduação em Administração - ENANPAD, 35., 2011. Anais... Rio de Janeiro: ANPAD, 2011.

SMOLA, Karen Wey; SUTTON, Charlotte D. Generational Differences: revisiting generational work values for the new millennium. Journal of Organizational Behavior. n. 4, v. 23, p. 363-382, Jun. 2002.

SOMMERLUND, Julie; BOUTAIBA, Sami. Borders of "the boundaryless career". Journal of Organizational Change Management. n. 4, v. 20, p. 525-538, 2007.

SULLIVAN, Sherry E.; ARTHUR, Michael B. The evolution of the boundaryless career concept: examining physical and psychological mobility. Journal of Vocational Behaviour. n. 1. v. 69, p. 19-29, Ago. 2006. 
TAPSCOTT, Don. A Hora da Geração Digital: Como os jovens que cresceram usando a internet estão mudando tudo, das empresas aos governos. Rio de Janeiro: Agir Negócios, 2010.

TELLES, Renato. A efetividade da "matriz de amarração" de Mazzon nas pesquisas em Administração. Revista de Administração. n. 4, v. 36, p. 64-72, 2001.

TWENGE, Jean M.; CAMPBELL, Stacy M. Generational differences in psychological traits and their impact on the workplace. Journal of Managerial Psychology. v. 23, p. 862-877, 2008.

TWENGE, Jean M. et al. Generational Differences in Work Values: Leisure and Extrinsic Values Increasing, Social and Intrinsic Values Decreasing. Journal of Management. n. 5, v. 36, p. 1117-1142, Set. 2010.

UNITE, Julie et al. Carrers and Age: Career Success for Older and Younger Workers. In: BRISCOE, Jon P. et al (Eds.). Careers around the world: individual and contextual perspectives. Nova York: Routledge, 2012.

VALE, Juliana Cidrack Freire do et al. O Comprometimento Organizacional entre Grupos Geracionais em uma Instituição Federal de Ensino Superior. In: Encontro Nacional da Associação Nacional dos Programas de Pós-Graduação em Administração - ENANPAD, 35. 2011. Anais... Rio de Janeiro: ANPAD, 2011.

VASCONCELOS, Kátia Cyrlene de Araújo et al. A geração Y e suas âncoras de carreira. In: Encontro de Gestão de Pessoas e Relações de Trabalho - EnGPR, 2., 2009, João Pessoa. Anais... João Pessoa: ANPAD, 2009.

VASCONCELLOS, Liliana.; GUEDES Luis Fernando Ascenção. E-surveys: Vantagens e Limitações dos Questionários Eletrônicos via Internet no Contexto da Pesquisa Científica. In: Seminários em Administração FEA-USP, 10., 2007, São Paulo. Anais... São Paulo, FEAUSP, 2007.

VELOSO, Elza Fatima Rosa. Carreiras sem fronteiras na gestão pessoal da transição profissional: um estudo com ex-funcionários de uma instituição com características de empresa pública. 2009. Tese (Doutorado em Administração) - Faculdade de Economia, Administração e Contabilidade, Universidade de São Paulo, São Paulo, 2009. Disponível em: <http://www.teses.usp.br/teses/disponiveis/12/12139/tde-11092009-101742/>. Acesso em: 21/05/2011.

VELOSO, Elsa Fátima Rosa et al. Percepção sobre carreiras inteligentes: diferenças entre as gerações Y, X e baby boomers. In: Encontro Nacional da Associação Nacional dos Programas de Pós-Graduação em Administração - ENANPAD, 32., 2008, Rio de Janeiro. Anais... Rio de Janeiro: ANPAD, 2008.

VELOSO, Elsa Fátima Rosa et al. Gerações e Carreira: A Relação entre as Percepções sobre Carreiras Inteligentes e sobre Crescimento Profissional nas Organizações. In: Encontro 
Nacional da Associação Nacional dos Programas de Pós-Graduação em Administração ENANPAD, 35., 2011, Rio de Janeiro. Anais... Rio de Janeiro: ANPAD, 2011.

VERGARA, Sylvia Constant. Projetos e relatórios de pesquisa em administração. 10. ed. São Paulo: Atlas, 2009.

WADE-BENZONI, Kimberly A. A Golden Rule Over Time: Reciprocity in Intergenerational Allocation Decisions. Academy of Management Journal. n. 5, v. 45, p. 1011-1028, 2002.

WELLER, Wivian. A atualidade do conceito de gerações de Karl Mannheim. Sociedade \& Estado. Brasília, n. 2, v.25, p.205-224, Ago. 2010. 


\section{APÊNDICES}

APÊNDICE 1: COMPARAÇÃO QUESTIONÁRIO BRISCOE et al (2006), SILVA (2009) E O UTILIZADO NA PRESENTE DISSERTAÇÃO

APÊNDICE 2: COMPARAÇÃO DA DESCRIÇÃO DA ESCALA DE RESPOSTA DAS QUESTÕES PROPOSTAS POR BRISCOE et al (2006), SILVA (2009) E A UTILIZADA NA PRESENTE DISSERTAÇÃO

APÊNDICE 3: E-MAIL ENVIADO PELA NEXTVIEW AO PÚBLICO ALVO DA PESQUISA

APÊNDICE 4: QUESTIONÁRIO ELETRÔNICO

APÊNDICE 5: CARGAS FATORIAIS DA ANÁLISE FATORIAL CONFIRMATÓRIA APÊNDICE 6: VALORES $t$ DE STUDENT DO BOOTSTRAPPING DA ANÁLISE FATORIAL CONFIRMATÓRIA 


\section{APÊNDICE 1: COMPARAÇÃO QUESTIONÁRIO BRISCOE et al (2006), SILVA (2009) E O UTILIZADO NA PRESENTE DISSERTAÇÃO}

\begin{tabular}{|c|c|c|c|c|}
\hline oㅡ & Dimensão & $\begin{array}{l}\text { Questionário Briscoe, Hall e DeMuth } \\
(2006)\end{array}$ & Questionário Silva (2009) & Questionário utilizado nesse estudo \\
\hline 1 & $\begin{array}{l}\text { Auto- } \\
\text { direcionamento }\end{array}$ & $\begin{array}{l}\text { When development opportunities have not } \\
\text { been offered by my company, l've sought } \\
\text { them out on my own. }\end{array}$ & $\begin{array}{l}\text { Quando oportunidades de desenvolvimento } \\
\text { não me foram oferecidas por minha } \\
\text { empresa, busquei-as por mim mesmo }\end{array}$ & $\begin{array}{l}\text { Quando oportunidades de desenvolvimento } \\
\text { não me foram oferecidas por minha } \\
\text { empresa, busquei-as por mim mesmo }\end{array}$ \\
\hline 2 & $\begin{array}{l}\text { Auto- } \\
\text { direcionamento }\end{array}$ & $\begin{array}{l}\text { I am responsible for my success or failure in } \\
\text { my career. }\end{array}$ & $\begin{array}{l}\text { Sou responsável por meu sucesso ou } \\
\text { fracasso em minha carreira }\end{array}$ & $\begin{array}{l}\text { Sou responsável por meu sucesso ou } \\
\text { fracasso em minha carreira }\end{array}$ \\
\hline 3 & $\begin{array}{l}\text { Auto- } \\
\text { direcionamento }\end{array}$ & $\begin{array}{l}\text { Overall, I have a very independent, self- } \\
\text { directed career. }\end{array}$ & $\begin{array}{l}\text { De um modo geral, tenho uma carreira } \\
\text { bastante independente e } \\
\text { exclusivamente por mim }\end{array}$ & $\begin{array}{l}\text { De um modo geral, tenho uma carreira } \\
\text { bastante independente e dirigida por mim }\end{array}$ \\
\hline 4 & $\begin{array}{l}\text { Auto- } \\
\text { direcionamento }\end{array}$ & $\begin{array}{l}\text { Freedom to choose my } \\
\text { one of my most import }\end{array}$ & $\begin{array}{l}\text { Um dos valores que mais prezo é a } \\
\text { liberdade de escolher o rumo que eu devo } \\
\text { dar à minha própria carreira }\end{array}$ & $\begin{array}{l}\text { Liberdade para escolher minha própria } \\
\text { trajetória de carreira é um dos meus valores } \\
\text { mais importantes }\end{array}$ \\
\hline 5 & $\begin{array}{l}\text { Auto- } \\
\text { direcionamento }\end{array}$ & I am in ch & Sou responsável pela minha própria carreira & $\begin{array}{l}\text { Estou no comando de minha própria } \\
\text { carreira }\end{array}$ \\
\hline 6 & $\begin{array}{l}\text { Auto- } \\
\text { direcionamento }\end{array}$ & $\begin{array}{l}\text { Ultimately, } \\
\text { my career } f\end{array}$ & $\begin{array}{l}\text { Em última instância, dependo de mim } \\
\text { mesmo para avançar em minha carreira }\end{array}$ & $\begin{array}{l}\text { No final das contas, dependo de mim } \\
\text { mesmo para avançar em minha carreira }\end{array}$ \\
\hline 7 & $\begin{array}{l}\text { Auto- } \\
\text { direcionamento }\end{array}$ & $\begin{array}{l}\text { Where my career is concer } \\
\text { much "my own person." }\end{array}$ & $\begin{array}{l}\text { No que diz respeito à minha carreira, sou } \\
\text { muito "mais eu" }\end{array}$ & $\begin{array}{l}\text { No que diz respeito à minha carreira, quem } \\
\text { toma as decisões sou eu }\end{array}$ \\
\hline 8 & $\begin{array}{l}\text { Auto- } \\
\text { direcionamento }\end{array}$ & $\begin{array}{l}\text { In the past I have relied more on myself than } \\
\text { others to find a new job when necessary. }\end{array}$ & $\begin{array}{l}\text { Tenho por costume confiar mais em mim do } \\
\text { que nos outros para achar um novo } \\
\text { emprego, quando necessário }\end{array}$ & $\begin{array}{l}\text { Em minhas experiências passadas, confiei } \\
\text { mais em mim mesmo do que em outras } \\
\text { pessoas para encontrar um novo emprego, } \\
\text { quando necessário }\end{array}$ \\
\hline 9 & $\begin{array}{l}\text { Orientação } \\
\text { pelos valores }\end{array}$ & $\begin{array}{l}\text { personal priorities } \\
\text { employer's prioriti }\end{array}$ & $\begin{array}{l}\text { Eu mesmo conduzo minha carreira, } \\
\text { baseado em minhas prioridades pessoais, e } \\
\text { não nas prioridades do meu empregador }\end{array}$ & $\begin{array}{l}\text { Eu conduzo minha própria carreira, } \\
\text { baseado(a) em minhas prioridades pessoais } \\
\text { e não nas prioridades de meu empregador }\end{array}$ \\
\hline 10 & $\begin{array}{l}\text { Orientação } \\
\text { pelos valores }\end{array}$ & $\begin{array}{l}\text { people eval } \\
\text { career. }\end{array}$ & $\begin{array}{l}\text { Não é muito importante para mim a forma } \\
\text { com que as pessoas avaliam as escolhas } \\
\text { que faço em minha carreira }\end{array}$ & $\begin{array}{l}\text { Não é muito importante p } \\
\text { com que as outras pes } \\
\text { escolhas que eu faço em r }\end{array}$ \\
\hline 11 & $\begin{array}{l}\text { Orientação } \\
\text { pelos valores }\end{array}$ & $\begin{array}{l}\text { What's most impc } \\
\text { about my career s } \\
\text { people feel about }\end{array}$ & $\begin{array}{l}\text { E mais importante para mim a maneira } \\
\text { como me sinto do que como as pessoas } \\
\text { pensam em relação ao meu sucesso na } \\
\text { carreira }\end{array}$ & $\begin{array}{l}\text { importa para mim é como eu } \\
\text { n relação a meu sucesso na } \\
\text { não como outras pessoas se } \\
\text { speito disso }\end{array}$ \\
\hline 12 & ien & $g$ that & $\begin{array}{l}\text { Sigo a minha consciência e os meus } \\
\text { valores mesmo que a minha empresa } \\
\text { solicite que eu faça algo que os contrarie }\end{array}$ & $\begin{array}{l}\text { própria consciência se a } \\
\text { a solicitar que eu faça algo } \\
\text { os meus valores }\end{array}$ \\
\hline 13 & ão & what & $\begin{array}{l}\text { arreira, o que eu acho que está } \\
\text { importante do que o que minha } \\
\text { sa }\end{array}$ & $\begin{array}{l}\text { tá certo em minha } \\
\text { te para mim do que } \\
\text { ha }\end{array}$ \\
\hline 14 & $\begin{array}{l}\text { Orientação } \\
\text { pelos valores }\end{array}$ & values & $\begin{array}{l}\text { Tenho por costume seguir meus próprios } \\
\text { valores mesmo quando a empresa me pede } \\
\text { para fazer algo com que eu não concordo }\end{array}$ & $\begin{array}{l}\text { Em minhas experiências passadas, eu } \\
\text { segui meus próprios valores mesmo quando } \\
\text { a empresa me pediu para fazer algo com o } \\
\text { qual eu não concordava }\end{array}$ \\
\hline 15 & de & 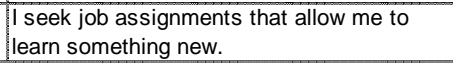 & $\begin{array}{l}\text { trabalho que me } \\
\text { novo }\end{array}$ & $\begin{array}{l}\text { Procuro tarefas que me permitam aprender } \\
\text { algo novo }\end{array}$ \\
\hline 16 & ce & th & $\begin{array}{l}\text { ar em projetos com } \\
\text { anizações }\end{array}$ & $\begin{array}{l}\text { Gostaria de trabalhar em projetos com } \\
\text { pessoas de várias organizações }\end{array}$ \\
\hline 17 & & uire me to & $\begin{array}{l}\text { Gosto de serviços que requeiram que eu } \\
\text { trabalhe fora da organização }\end{array}$ & $\begin{array}{l}\text { Gosto de tarefas que requeiram que eu } \\
\text { trabalhe fora da organização }\end{array}$ \\
\hline 18 & $\begin{array}{l}\text { Mobilidade } \\
\text { psicológica }\end{array}$ & me to work & $\begin{array}{l}\text { Gosto de tarefas em meu trabalho que } \\
\text { requeiram que eu trabalhe além do meu } \\
\text { próprio departamento }\end{array}$ & $\begin{array}{l}\text { Gosto de tarefas em meu trabalho que } \\
\text { requeiram que eu trabalhe além do meu } \\
\text { próprio departamento }\end{array}$ \\
\hline 19 & $\begin{array}{l}\text { de } \\
\text { ica }\end{array}$ & ny & $\begin{array}{l}\text { Gosto de trabalhar com pessoas fora da } \\
\text { minha organização }\end{array}$ & $\begin{array}{l}\text { Gosto de trabalhar com pessoas fora da } \\
\text { minha organização }\end{array}$ \\
\hline 20 & $\begin{array}{l}\text { Mobilidade } \\
\text { psicológica }\end{array}$ & $\begin{array}{l}\text { ct with } \\
\text { is. }\end{array}$ & $\begin{array}{l}\text { Gosto de trabalhos que requeiram que eu } \\
\text { interaja com pessoas de várias } \\
\text { organizações diferentes }\end{array}$ & $\begin{array}{l}\text { Gosto de trabalhos que requeiram que eu } \\
\text { interaja com pessoas de várias } \\
\text { organizações diferentes }\end{array}$ \\
\hline 21 & $\begin{array}{l}\text { bilidade } \\
\text { cológica }\end{array}$ & lat & $\begin{array}{l}\text { Tenho buscado oportunidades de trabalho } \\
\text { que me permitam trabalhar fora da } \\
\text { organização }\end{array}$ & $\begin{array}{l}\text { No passado, busquei oportunidades que me } \\
\text { permitissem trabalhar fora da organização }\end{array}$ \\
\hline 22 & de & and & $\begin{array}{l}\text { Sinto-me motivado quando enfrento } \\
\text { experiências e situações novas }\end{array}$ & $\begin{array}{l}\text { Sinto-me motivado quando enfrento } \\
\text { experiências e situações novas }\end{array}$ \\
\hline 23 & $\begin{array}{l}\text { Mobilidade } \\
\text { física }\end{array}$ & $\begin{array}{l}\text { Ilike the predictability that comes with } \\
\text { working continuously for the same }\end{array}$ & $\begin{array}{l}\text { Gosto da previsibilidade proveniente de se } \\
\text { trabalhar continuamente para a mesma } \\
\text { organização }\end{array}$ & $\begin{array}{l}\text { Gosto da previsibilidade decorrente de se } \\
\text { trabalhar continuamente para a mesma } \\
\text { organização }\end{array}$ \\
\hline 24 & $\begin{array}{l}\text { Mobilidade } \\
\text { física }\end{array}$ & $\begin{array}{l}\text { I would feel very lost if I couldn't work for my } \\
\text { current organization. }\end{array}$ & $\begin{array}{l}\text { Eu me sentiria bastante perdido se não } \\
\text { pudesse trabalhar para a minha atual } \\
\text { organização }\end{array}$ & $\begin{array}{l}\text { Eu me sentiria bastante perdido se não } \\
\text { pudesse trabalhar para a minha atual } \\
\text { organização }\end{array}$ \\
\hline 25 & $\begin{array}{l}\text { Mobilidade } \\
\text { física }\end{array}$ & $\begin{array}{l}\text { Tam familiar } \\
\text { loyment }\end{array}$ & $\begin{array}{l}\text { Prefiro permanecer em uma empresa com a } \\
\text { qual eu seja familiarizado do que procurar } \\
\text { por outro emprego em outro lugar }\end{array}$ & $\begin{array}{l}\text { Prefiro permanecer em uma empresa com a } \\
\text { qual eu esteja familiarizado do que procurar } \\
\text { por outro emprego em outro lugar }\end{array}$ \\
\hline 26 & $\begin{array}{l}\text { Mobilidade } \\
\text { física }\end{array}$ & fetime & $\begin{array}{l}\text { Se minha empresa proporcionasse emprego } \\
\text { vitalício, eu nunca iria querer procurar } \\
\text { trabalho em outras organizações }\end{array}$ & $\begin{array}{l}\text { Se minha empresa proporcionasse emprego } \\
\text { vitalício, eu nunca iria querer procurar } \\
\text { trabalho em outras organizações }\end{array}$ \\
\hline 27 & ca & ideal career I would & $\begin{array}{l}\text { O meu ideal de carreira seria tra } \\
\text { apenas para uma única organização }\end{array}$ & $\begin{array}{l}\text { O meu ideal de carreira seria trab } \\
\text { apenas para uma única organização }\end{array}$ \\
\hline
\end{tabular}




\section{APÊNDICE 2: COMPARAÇÃO DA DESCRIÇÃO DA ESCALA DE RESPOSTA DAS QUESTÕES PROPOSTAS POR BRISCOE et al (2006), SILVA (2009) E A UTILIZADA NA PRESENTE DISSERTAÇÃO}

\begin{tabular}{|c|c|c|}
\hline $\begin{array}{l}\text { Escala Briscoe, Hall e } \\
\text { DeMuth (2006) }\end{array}$ & Escala Silva (2009) & $\begin{array}{l}\text { Escala utilizada nesse } \\
\text { estudo }\end{array}$ \\
\hline $\begin{array}{l}\text { Please indicate the extent to } \\
\text { which the following statements } \\
\text { are true for you, using the } \\
\text { following response scale. } \\
\text { Please circle or place an "X" } \\
\text { over the appropriate response } \\
1 \text { - to little extent or no extent; } \\
2 \text { - to a limited extent; } \\
3 \text { - to some extent; } \\
4 \text { - to a considerable extent; } \\
5 \text { - to a great extent; }\end{array}$ & $\begin{array}{l}\text { Por favor, indique em que } \\
\text { medida as seguintes } \\
\text { declarações são verdadeiras } \\
\text { para você usando a escala de } \\
\text { resposta apresentada. Favor } \\
\text { circular ou colocar um "X" na } \\
\text { resposta apropriada. } \\
1 \text { - um pouco ou nada; } \\
2 \text { - de forma limitada; } \\
3 \text { - até certo ponto; } \\
4 \text { - de forma considerável; } \\
5 \text { - muito }\end{array}$ & $\begin{array}{l}\text { Por favor, indique o seu grau de } \\
\text { concordância com cada } \\
\text { sentença apresentada abaixo. } \\
1 \text { - discordo totalmente } \\
2 \text { - discordo parcialmente } \\
3 \text { - não concordo nem discordo } \\
4 \text { - concordo parcialmente } \\
5 \text { - concordo totalmente }\end{array}$ \\
\hline
\end{tabular}




\section{APÊNDICE 3: E-MAIL ENVIAdo PELA NEXTVIEW AO PÚBLICO ALVO DA PESQUISA}

Olá!

A Nextview e a Cia de Talentos convidam você a participar da pesquisa "Perfil de Carreira dos Jovens Brasileiros". Essa é uma pesquisa acadêmica conduzida por Talita Cordeiro, como parte de seu programa de mestrado na FEA-USP.

O tempo para responder é de cerca de 10 minutos e suas respostas são confidenciais. O link para a pesquisa é https://www.surveymonkey.com/s/QCBLD89 e ele estará disponível até o dia 27 de Abril de 2012.

Completando o questionário e registrando seu e-mail no final da página, você receberá um sumário de seu perfil de carreira com sugestões para seu desenvolvimento profissional, após término da pesquisa, que está previsto para agosto/2012.

Qualquer dúvida entre em contato pelo e-mail: talitacordeiro@usp.br .

Obrigada por sua participação!

Cia de Talentos, Nextview e Talita Cordeiro 


\section{APÊNDICE 4: QUESTIONÁRIO ELETRÔNICO}

Disponível em: https://www.surveymonkey.com/s/QCBLD89 de 8 de março à 14 de maio de 2012.

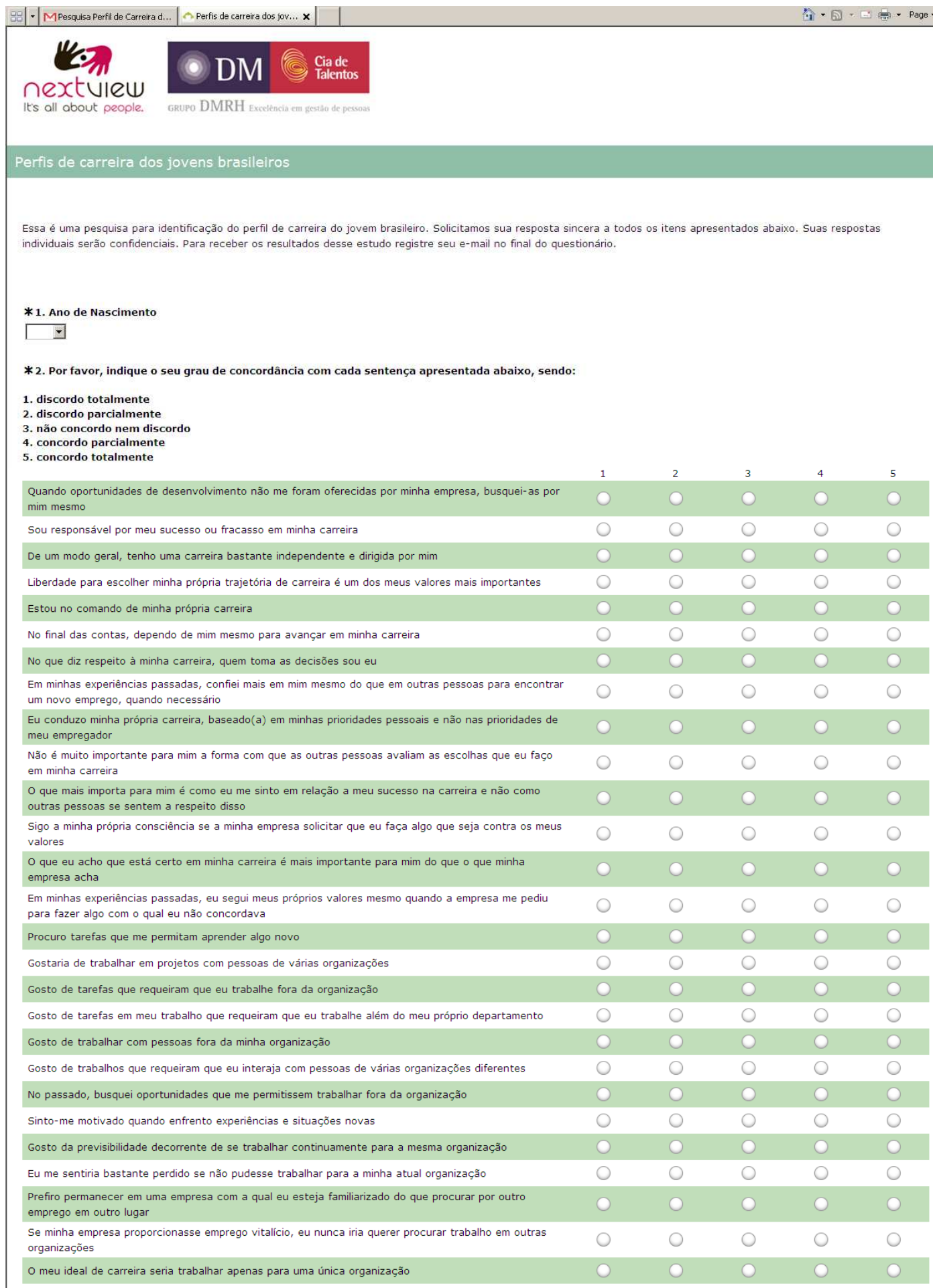


*3. Gênero:
Masculino
Feminino
*4. Escolaridade:
Ensino fundamental
Ensino médio
Ensino superior
Pós-graduação
*5. Estado Civil:
solteiro
Casado / União Estável
Divorciado / Separado
*6. Tem filhos?
Não tenho filhos
sim, tenho 1
sim, tenho 2
sim, tenho 3 ou mais
*7. Estado em que reside:
*8. Cidade em que reside:

*9. Tempo médio diário de utilização da internet:

Menos de 1 hora

De 1 a 2 horas

De 2 a 4 horas

De 4 a 8 horas

Mais de 8 horas

* 10. Está trabalhando atualmente

$\operatorname{sim}$

Não

*11. Anos de experiência profissional (incluindo estágio)

Não tenho experiência profissional

Menos de 1 ano

Entre 1 e 2 anos

Entre 2 e 3 anos

Entre 3 e 5 anos

Entre 5 e 7 anos

Mais de 7 anos

* 12. Cargo:

Diretor / Gerente

Coordenador / Supervisor / Consultor

Analista / Auxiliar / Assistente

Trainee

Estagiário

Outro (especifique)

* 13. Número de empresas para as quais já trabalhou nos últimos 5 anos:

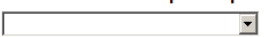

*14. Renda média mensal:

15. Muito obrigada por sua participação!

Para receber os resultados desse estudo e um breve sumário de seu perfil de carreira para comparação, registre seu e-mail abaixo:

E-mail: 


\begin{tabular}{|c|c|c|c|c|}
\hline Questão & AD & OV & MP & MF \\
\hline V2 & $\mathbf{0 , 5 8 5 3 1 5}$ & 0,159694 & 0,168188 & 0,117054 \\
\hline V3 & $\mathbf{0 , 6 8 6 7 2 4}$ & 0,205555 & 0,185938 & 0,092428 \\
\hline V4 & $\mathbf{0 , 6 6 7 1 8 8}$ & 0,240624 & 0,204396 & 0,117951 \\
\hline V5 & $\mathbf{0 , 7 9 9 7 5 6}$ & 0,245666 & 0,183534 & 0,103995 \\
\hline V6 & $\mathbf{0 , 6 3 8 5 1 8}$ & 0,178935 & 0,142121 & 0,044934 \\
\hline V7 & $\mathbf{0 , 7 6 4 5 9 8}$ & 0,328586 & 0,20853 & 0,123154 \\
\hline V9 & 0,336969 & $\mathbf{0 , 6 3 7 5 5 1}$ & 0,108922 & 0,033952 \\
\hline V10 & 0,155133 & $\mathbf{0 , 6 0 6 3 0 7}$ & $-0,01131$ & $-0,03961$ \\
\hline V11 & 0,234831 & $\mathbf{0 , 6 6 4 7 4 1}$ & 0,074592 & 0,021422 \\
\hline V12 & 0,179369 & $\mathbf{0 , 6 3 1 8 8 7}$ & 0,15239 & 0,101036 \\
\hline V13 & 0,207876 & $\mathbf{0 , 7 3 6 9 5 7}$ & 0,076552 & 0,063229 \\
\hline V14 & 0,144924 & $\mathbf{0 , 6 0 2 8 5 5}$ & 0,15701 & 0,035174 \\
\hline V16 & 0,210924 & 0,098137 & $\mathbf{0 , 7 7 8 5 8 4}$ & 0,20268 \\
\hline V17 & 0,125225 & 0,122397 & $\mathbf{0 , 7 0 8 9 8 1}$ & 0,172358 \\
\hline V18 & 0,200863 & 0,112125 & $\mathbf{0 , 7 4 7 7 7 8}$ & 0,184755 \\
\hline V19 & 0,184364 & 0,117178 & $\mathbf{0 , 8 6 6 0 3 7}$ & 0,214462 \\
\hline V20 & 0,206132 & 0,089964 & $\mathbf{0 , 8 5 3 2 1 3}$ & 0,198499 \\
\hline V21 & 0,104624 & 0,069258 & $\mathbf{0 , 5 5 6 1 0 4}$ & 0,084399 \\
\hline V22 & 0,328534 & 0,13684 & $\mathbf{0 , 5 8 2 5 4 6}$ & 0,238212 \\
\hline V23 & 0,043616 & 0,028114 & 0,189552 & $\mathbf{0 , 6 3 9 6 6 6}$ \\
\hline V24 & 0,088211 & 0,046114 & 0,131814 & $\mathbf{0 , 6 3 8 0 9 5}$ \\
\hline V25 & 0,088648 & 0,011078 & 0,174812 & $\mathbf{0 , 7 4 2 7 4 9}$ \\
\hline V26 & 0,1397 & 0,049702 & 0,199815 & $\mathbf{0 , 7 9 9 5 3 5}$ \\
\hline V27 & 0,148672 & 0,06941 & 0,212104 & $\mathbf{0 , 7 6 8 7 3 4}$ \\
\hline & & & & \\
\hline
\end{tabular}


APÊNDICE 6: VALORES $t$ DE STUDENT DO BOOTSTRAPPING DA ANÁLISE FATORIAL CONFIRMATÓRIA

\begin{tabular}{|c|c|c|c|c|}
\hline & AD & OV & MP & MF \\
\hline V2 & 4,866777 & & & \\
\hline V3 & 9,111457 & & & \\
\hline V4 & 9,08289 & & & \\
\hline V5 & 17,29443 & & & \\
\hline V6 & 6,569155 & & & \\
\hline V7 & 14,4699 & & & \\
\hline V9 & & 6,418987 & & \\
\hline V10 & & 4,709703 & & \\
\hline V11 & & 5,43872 & & \\
\hline V12 & & 4,493058 & & \\
\hline V13 & & 6,38076 & & \\
\hline V14 & & 4,106801 & & \\
\hline V16 & & & 13,49251 & \\
\hline V17 & & & 9,511137 & \\
\hline V18 & & & 11,25669 & \\
\hline V19 & & & 26,31951 & \\
\hline V20 & & & 20,32707 & \\
\hline V21 & & & 6,741664 & \\
\hline V22 & & & 5,324049 & \\
\hline V23 & & & & 4,692393 \\
\hline V24 & & & & 4,452263 \\
\hline V25 & & & & 5,322992 \\
\hline V26 & & & & 5,894141 \\
\hline V27 & & & & 5,56474 \\
\hline
\end{tabular}




\section{ANEXOS}

\section{ANEXO A - DIVULGAÇÃO DA PESQUISA NA INTERNET}

Disponível em: <http://msn.clickcarreira.com.br/querocrescer/2012/5/7/3893/descubra-quale-o-seu-perfil-de-carreira.html>. Acesso em: 11 de maio de 2012.

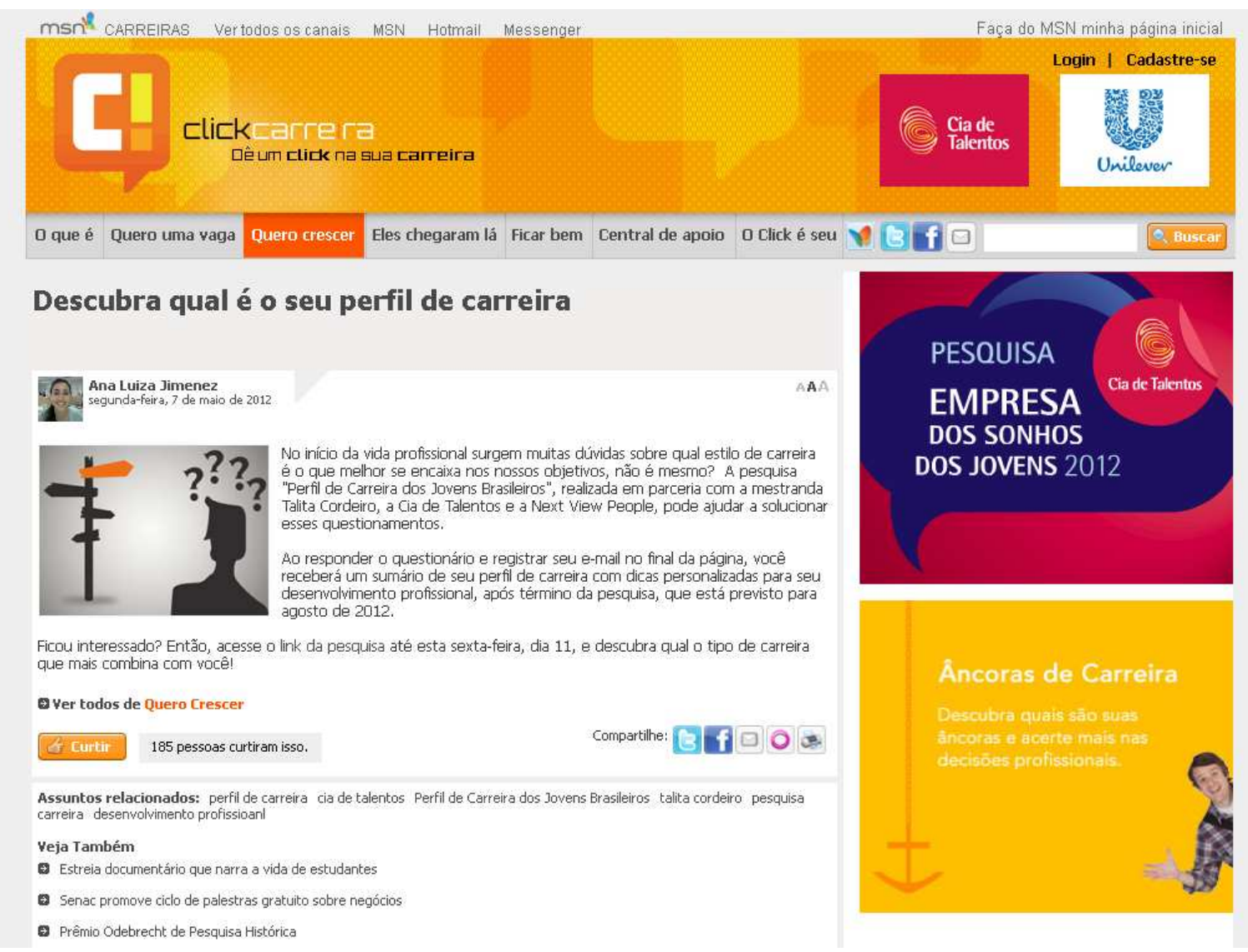

